UNIVERSIDADE DE SÃO PAULO

INSTITUTO DE FÍSICA

\title{
MODIFICAÇÃO DE SUPERFÍCIES PARA USO EM CULTURA DE CÉLULAS
}

\author{
WAGNER WLYSSES RODRIGUES DE ARAÚJO
}

Orientadora: Prof ${ }^{a}$. Dr ${ }^{\mathrm{a}}$. Maria Cecília Barbosa Silveira Salvadori

Tese apresentada ao Instituto
de Física da Universidade de
São Paulo para a obtenção do
título de Doutor em Ciências

\section{Banca Examinadora:}

Prof $^{\mathrm{a}}$. Dr ${ }^{\mathrm{a}}$. Maria Cecília Barbosa Silveira Salvadori (IFUSP)

Prof. Dr. Adriano Mesquita Alencar (IFUSP)

Prof. Dr. Nemitala Added (IFUSP)

Prof. Dr. Silvio Eduardo Dualibi (UNIFESP)

Prof. Dr. Vladimir Jesus Trava Airoldi (INPE)

SÃO PAULO 
WAGNER WLYSSES RODRIGUES DE ARAÚJO

MODIFICAÇÃO DE SUPERFÍCIES PARA USO EM CULTURA DE CÉLULAS 
Tese sob o título "MODIFICAÇÃO DE SUPERFÍCIES PARA USO EM CULTURA DE CÉLULAS”, defendida em Dezembro de 2014 por Wagner Wlysses Rodrigues de Araújo e aprovada , em São Paulo, São Paulo, pela banca examinadora constituída pelos doutores:

Prof $^{a}$. Dr ${ }^{\mathrm{a}}$. Maria Cecília Barbosa Silveira Salvadori Instituo de Física da Universidade de São Paulo

Departamento de Física Aplicada

Orientadora

$\operatorname{Prof(a).~Dr(a).~}$

$\operatorname{Prof}(a) . \operatorname{Dr}(a)$.

$\operatorname{Prof(a).~Dr(a).~}$

$\operatorname{Prof(a).~Dr(a).~}$ 
Aos meus Pais

José Evangelista e Ana Lúcia, Às minhas meninas Fernanda e Sarah, é claro! 


\section{Sumário}

Sumário $\quad$ p.i

$\begin{array}{ll}\text { Agradecimentos } & \text { p.v }\end{array}$

$\begin{array}{lll}\text { Epigrafe } & \text { p.vii }\end{array}$

1 INTRODUÇÃOO p. 1

1.1 Colocação do Problema. . . . . . . . . . . . . . . p. 1

1.2 Motivação. . . . . . . . . . . . . . . . p. 3

1.3 Relevância do ponto de vista tecnológico. . . . . . . . . . . p. 3

1.4 Cultura de células em superfícies modificadas. . . . . . . . . . p. 4

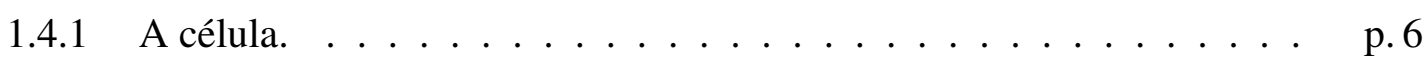

1.4.2 Células e as escalas de tamanhos. . . . . . . . . . p. 8

1.4.3 Apoptose versus Necrose. . . . . . . . . . . . p. 10

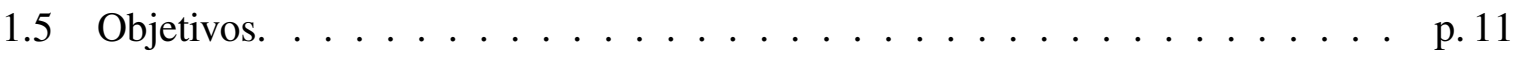

1.6 Organização do trabalho. . . . . . . . . . . . . . . p. 12

2 MATERIAIS E MÉTODOS. p. 13

2.1 Fabricação das superfície lisas. . . . . . . . . . . . . p. 13

2.2 Modificação de Superfície. . . . . . . . . . . . . . . . . p. 16 
2.2.1 Tratamento por plasma. . . . . . . . . . . p. 16

2.2.2 Implantação iônica. . . . . . . . . . . . . . . . p. 18

2.2.3 Simulação numérica realizada no código TRIDYN. . . . . . . . . . p. 20

2.3 Superfícies Microfabricadas. . . . . . . . . . . . . . p. 21

2.3.1 Fabricação de microcavidades em SU-8. . . . . . . . . . . . p. 21

2.4 Materiais e métodos em cultura de células. . . . . . . . . . . p. 25

2.4.1 Descongelamento das células. . . . . . . . . . . . . p. 26

2.4.2 Cultivo de Células. . . . . . . . . . . . . . . p. 26

2.4.3 Contagem das células para semear as superfícies. . . . . . . . . p. 27

2.4.4 Criopreservação (Congelamento das células) . . . . . . . . . . . . p. 28

2.5 Caracterização das superfícies lisas. . . . . . . . . . . . . . . . p. 29

2.5.1 A análise de RBS (Rutherford Backscattering Spectrometry). . . . . . p. p. 29

2.5.2 Caracterização por Ângulo de contato e Energia de Superfície. . . . . p. 30

2.5.3 Microscopia de Força Atômica. . . . . . . . . . . . . p. 33

2.6 Caracterização da superfícies microfabricadas. . . . . . . . . . . . . p. 36

2.6.1 Ângulo de Contato. . . . . . . . . . . . . . . . . . p. 36

2.6.2 Microscopia Eletrônica de Varredura (MEV). . . . . . . . . . . . p. 37

2.7 Caracterização do desempenho da cultura de células nas diversas superfícies. p. 38

2.7.1 Teste de viabilidade celular. . . . . . . . . . . . . p. 38

2.7 .2 Fator de Forma. . . . . . . . . . . . . . . p. 39

2.7.3 Microscopia Óptica de Fluorescência. . . . . . . . . . . . . . . p. 39

2.7.4 Análise da função de correlação em imagem de microscopia óptica. p.42

3 RESULTADOS EXPERIMENTAIS E DISCUSSÃO. p. 45

3.1 Resultados para superfícies lisas. . . . . . . . . . . . . . p. 45

3.1.1 Resultados para o fator de forma. . . . . . . . . . . p. 46

3.1.2 Resultados para Tratamento por plasma. . . . . . . . . . . . p. 47 
3.1.3 Resultados de Implantação iônica. . . . . . . . . . . . . . . . . . p. 50

3.1.4 Resultados de energia de superfície e AFM para superfície modificadas por implantação. . . . . . . . . . . . . . . . . p. 53

3.2 Resultados para as superfícies microestruturadas. . . . . . . . . . . p. 55

3.2.1 Resultados para as superfície microestruturadas análisadas por

Microscopia Óptica de fluorescência. . . . . . . . . . . . . . p. 56

3.2.2 Resultados para as superfície microestruturadas análisadas por

Microscopia Óptica. . . . . . . . . . . . . . . . . . p. 58

3.2.3 Resultados para a análise de correlação. . . . . . . . . . . . . . p. 64

4 Sumário e Conclusão $\quad$ p. 68

5 Perspectivas de trabalhos futuros. $\quad$ p. 73

$\begin{array}{ll}\text { Apêndices } & \text { p. } 74\end{array}$

A Resultados de calibração para produção de microcavidades em SU-8 2005 . p. 74

$\begin{array}{ll}\text { Apêndices } & \text { p. } 80\end{array}$

B Medidas do tamanho das células CHO por MEV. $\quad$ p. 80

$\begin{array}{ll}\text { Apêndices } & \text { p. } 82\end{array}$

C Definição de número de células a serem semeadas utilizando marcação de $\begin{array}{lr}\text { núcleos com o fluoróforo DAPI. } & \text { p. } 82\end{array}$

$\begin{array}{ll}\text { Apêndices } & \text { p. } 85\end{array}$

D Parâmetros obtidos a partir da análise da função de correlação. $\quad$ p. 85

$\begin{array}{lr}\text { Apêndices } & \text { p. } 89\end{array}$

$\begin{array}{lr}\text { E Protocolos de Cultura. } & \text { p. } 89\end{array}$ 


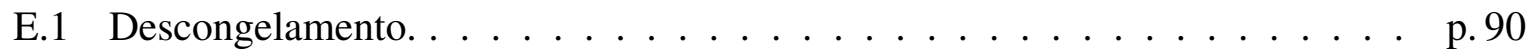

E.2 Passagem das células (Repique) . . . . . . . . . . . . . . . . . p. 90

E.3 Protocolo para contagem de células. . . . . . . . . . . . . p.91

E.4 Teste de viabilidade usando trypan blue (azul de tripano) . . . . . . . . . . p.93

E.5 Procedimento de uso da solução Fixadora para

MEV (Microscopia Eletrônica de Varredura). . . . . . . . . . . . . . . . . . p.94

E.6 Procedimento de uso da solução Fixadora para

Microscopia óptica de fluorescência (DAPI) . . . . . . . . . . . . . . . p.96

$\begin{array}{lr}\text { Apêndices } & \text { p.97 }\end{array}$

$\begin{array}{lr}\text { F Resumo publicado em revista indexada. } & \text { p.97 }\end{array}$

$\begin{array}{lr}\text { Apêndices } & \text { p.98 }\end{array}$

$\begin{array}{lr}\text { G Artigo publicado em revista indexada. } & \text { p.98 }\end{array}$

$\begin{array}{lr}\text { Referências Bibliográficas } & \text { p. } 99\end{array}$ 


\section{Agradecimentos}

- A DEUS por minha vida;

- Aos meus PAIS, José Evangelista de Araújo e Ana Lúcia Rodrigues de Araújo, pela educação e apoio em todos os momentos de minha vida, e meus irmãos Hérica Gabriela R. de Araújo e José Maria de Araújo Netto por todo apoio;

- A alguns membros da família, pelo apoio e ambiente oferecido;

- A Prof ${ }^{a}$. Dr ${ }^{a}$. Maria Cecília Barbosa da Silveira Salvadori pela oportunidade, pelo seu trabalho sério, pela confiança na realização deste trabalho, por toda ajuda, dedicação, constante orientação e por ampliar a minha visão científica. Todo esse conjunto resumese em uma formação acadêmica de qualidade a mim concedida;

- A talentosa especialista de laboratório Dra . Fernanda de Sá Teixeira, agradeço a dedicação, por estar sempre presente, as tantas solicitudes prestadas, as discussões, tanto no compêndio científico quanto aos valiosos conselhos pessoais[;)];

- Às Prof ${ }^{\mathrm{a}}$.s Dr ${ }^{\mathrm{a}}$.s Daisy Maria Salvadori e Glenda Nicioli Silva por todo suporte e oportunidade de aprendizado sobre esse mundo novo chamado Célula;

- Ao Professor Ian Brown por todos ensinamentos;

- A todos meus AMIGOS, que me aturaram até agora (que continue assim...), pela amizade e compreensão;

- A Valdete por toda ajuda;

- Aos NOBRES companheiros que estiveram no Laboratório, Márcio Roberto, Guido Gabriel, Leandro Toshio; 
- Aos Aos NOBRES companheiros atualmente no Laboratório, Heitor Amorim, Dennis Brennes, Raíssa Oblitas, Roman Spirin, Leonardo Sgubin e ao demais espalhados pelo Brasil afora [:)];

- I would like to give my sincerely acknowledgments to all communities of open source software that delivers us great pieces of softwares, and the ones that were massively utilized in this work:

- Opensuse (opensuse.org),

- KDE (kde.org),

- Blender 3d (blender.org),

- Gimp (gimp.org),

- Inkscape (inkscape.org),

- Gwyddion (gwyddion.net),

- Libreoffice (libreoffice.org),

- Draftsigth (http://www.3ds.com/products-services/draftsight/overview/),

- ImageJ (http://imagej.nih.gov/ij/),

- Python (python.org),

- QtiPlot (qtiplot.com),

- MasterPDF Editor (http://code-industry.net/pdfeditor.php),

- Aos meus professores de graduação, Helder Nunes da Cunha e José Pimentel de Lima pela disponibilidade e por todo o apoio e orientação, apoio este que foi ponto de partida para que pudesse chegar até aqui e a concluir mais esta etapa da minha formação;

- Ao Conselho de Aperfeiçoamento do Ensino Superior - CAPES ao Conselho Nacional de Pesquisa - CNPq e a Fundação de Amparo a Pesquisa do Estado de São Paulo - FAPESP pelo suporte financeiro e oportunidades;

- A todos que contribuíram direta e indiretamente para que este trabalho fosse realizado deixo aqui um grande, SOU-TE GRATO!. 
"If you hear a voice within you say you cannot paint, then by all means paint, and that voice will be silenced."

Vincent van Gogh. 


\section{Lista de Figuras}

1.1 Número de publicações nos últimos 40 anos encontrados no google escolar acerca do assunto adesão celular. A linha pontilhada é referente a tendência de crescimento. . . . . . . . . . . . . . . . p. 2

1.2 Número de publicações nos últimos 40 anos encontrados no google escolar acerca do assunto adesão celular e relacionando com DLC, SU-8 e PDMS. A linha pontilhada é referente a tendência de crescimento. . . . . . . . . p. 2

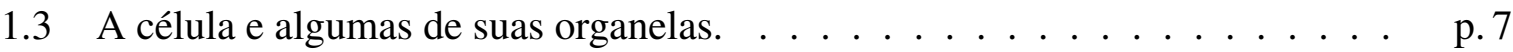

1.4 A célula e as suas respostas com relação ao micro ambiente. Figura adaptada

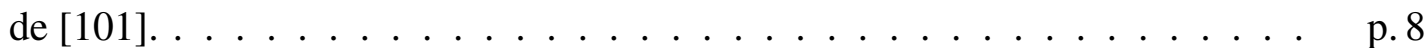

1.5 Esquema ilustrativo da organização celular do sistema epitelial. . . . . . . . . p.9

2.1 Esquema ilustrativo da montagem do canhão de plasma. . . . . . . . . . p. 16

2.2 Ilustração esquemática do canhão de plasma de catodo oco. . . . . . . . . . . p. 17

2.3 Canhão de plasma (hollow-cathode plasma gun) em operação com o gás $S F_{6}$. p. 18

2.4 Canhão de plasma em operação com o gás $O_{2} \ldots \ldots \ldots \ldots$. . . . . . . . . . p. 18

2.5 Na figura temos o esquema simplificado do sistema de implantação iônica. Em $E_{i}=e Q V_{e x t}$, têm-se que $E_{i}$ é a energia final dos íons, $e$ a carga do elétron, $Q$ o estado de carga dos íons, e $V_{e x t}=V_{p l}-V_{c h}$ é a queda de tensão no extrator, $V_{p l}$ é o potencial do plasma e $V_{c h}$ é o potencial da câmara. . . . . . . . . p. 19

2.6 Visão em corte do implantador em 3D . . . . . . . . . . . . . . . . . p. 20

2.7 Ilustração mostrando a diferença entre elétron-resistes positivos e negativos. . p. 22 
2.8 Na esquerda temos um exemplo de célula unitária para produção de um array por feixe de elétrons gerando uma área litografada de $8 \times 8 \mathrm{~mm}^{2}$, medida na figura em microns. Na direita temos um exemplo de array construído a partir da célula unitária. . . . . . . . . . . . . . . . . . . . p. . 24

2.9 Ilustração dos padrões que foram utilizados, (a) é mostrado a seção transversal do padrão. Em (b) é mostrado a visão de cima do padrão. Em (c) é mostrado uma visão em perspectiva do padrão. . . . . . . . . . . . . . . p. 25

2.10 Figura ilustrativa do padrão gravado na câmara de Neubauer. . . . . . . . . p. 27

2.11 Considerando o líquido sonda como sendo água, a ilustração da esquerda mostra um exemplo de superfície hidrofóbica (ângulo de contato $>90^{\circ}$ ). A ilustração da direita apresenta um exemplo de gota em uma superfície hidrofílica (ângulo de contato $<90^{\circ}$ ). . . . . . . . . . . . . . p. 30

2.12 Ajuste do ângulo de contato calculado pelo software de controle do equipamento CAM200. $\Theta_{A}$ e $\Theta_{R}$ são os ângulos de avanço e recesso, respectivamente. p.33

2.13 Esquema ilustrativo do funcionamento do AFM. . . . . . . . . . . . . p. 34

2.14 Esquema apresentando o princípio básico de funcionamento de um AFM de

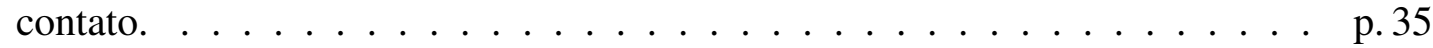

2.15 Figura do ponto de intersecção entre sólido, líquido e vapor ilustrando a formação do ângulo de contato . . . . . . . . . . . . . . . . . p.36

2.16 (a) temos a coluna óptico-eletrônica de um Microcópio Eletrônico de Varredura. (b) Volume de interação na amostra atingida pelo feixe de elétrons. . . . p.38

2.17 Ilustração da variação do fator de forma $F_{f}$ com a variação da geometria. . . . p. 39

2.18 Ilustração do cubo de filtros utilizado na microscopia de fluorescência. . . . . p. p. 42

2.19 Na figura (a) temos uma imagem da superfície da amostra contendo estruturas Hexagonais litografados com células semeadas e marcadas com DAPI. Na figura (b) temos uma imagem contendo apenas a informação do canal azul da micrografia. Na figura (c) temos a imagem binarizada do canal azul. . . . . . p. 44

3.1 (a) Imagem de MO típica de células crescidas em SU-8, apresentando formato alongado, gerando fator de forma de $F_{f}=0,52$. (b) Imagem de MO típica de células crescidas em PDMS, apresentando formato circular, gerando um fator de forma de $F_{f}=0,98$. Barra de $100 \mu m . \ldots$. . . . . . . 46 
3.2 Em (a), (b) e (c) temos uma imagem típica de MO das superfícies de DLC-O, DLC-F e DLC, respectivamente, marcados com trypan blue. Os círculos indicam exemplos de células mortas. Em (e), (f) e (g) temos uma imagem típica de microscopia óptica de fluorescência das superfícies de DLC-O, DLC-F e DLC, respectivamente, marcados com o fluoróforo DAPI. As imagens marcadas com DAPI possuem tamanhos de $437 \times 328 \mu \mathrm{m}^{2}$ ou $0,17 \mu \mathrm{m} /$ pixel. . p. 48

3.3 Número de células vivas por unidade de área em três experimentos independentes realizados sobre superfícies de DLC tratadas com plasma de oxigênio (DLC-O) e com plasma de hexafluoreto de enxofre (DLC-F). Como referência foi utilizada uma superfície de DLC sem tratamento em plasma. . . . . . . .

3.4 Número de células mortas por unidade de área em três experimentos independentes realizados sobre superfícies de DLC tratadas com plasma de oxigênio (DLC-O) e com plasma de hexafluoreto de enxofre (DLC-F). Como referência foi utilizada uma superfície de DLC sem tratamento em plasma. . .

3.5 Número de núcleos por unidade de área marcados com DAPI em três experimentos independentes realizados sobre superfícies de DLC tratadas com plasma de oxigênio (DLC-O) e com plasma de hexafluoreto de enxofre (DLCF). Como referência foi utilizada uma superfície de DLC sem tratamento em plasma.

3.6 Energia de superfície obtida para as superfícies de DLC tratado com plasma de oxigênio (DLC-O), com plasma de hexafluoreto de enxofre (DLC-F) e DLC sem tratamento. . . . . . . . . . . . . . . . p.50

3.7 Fração dos átomos implantados em função da profundidade obtida pelo código TRIDYN.

3.8 Número de células vivas por unidade de área em três experimentos independentes realizados sobre superfície lisa de SU-8 com implantação de 1,2 × $10^{16}$ átomos $/ \mathrm{cm}^{2}$ de prata com energia de $8 \mathrm{keV}$. Como referência foi utilizada uma superfície lisa de SU-8, sem implantação. . . . . . . . . . . . . p.52

3.9 Número de células mortas por unidade de área em três experimentos independentes realizados sobre superfície lisa de SU-8 com implantação de $1,2 \times 10^{16}$ átomos $/ \mathrm{cm}^{2}$ de prata com energia de $8 \mathrm{keV}$. Como referência foi utilizada uma superfície lisa de SU-8, sem implantação. . . . . . . . . . . . p.52

3.10 Micrografia AFM da superfície original de SU-8. . . . . . . . . . . . p. 54 
3.11 Micrografia AFM da superfície de SU-8 modificada pela implantação de Ag. p.54

3.12 Micrografias de MEV mostrando na figura (a) a superfície do material SU8 originalmente depositado. Na figura (b) é apresentado para HEX-12, na figura (c) para HEX-30, na figura (d) para HEX-80, na figura (e) para HEX280 e na figura (f) para HEX-560.

3.13 Imagens típicas da cultura de células realizada e os núcleos marcados pelo fluoróforo DAPI nas seguintes superfícies: (a) SU-8 liso, (b) HEX-12, (c) HEX-30 (d) HEX-80 (e) HEX-280 e (f) HEX-560. A barra indica $100 \mu \mathrm{m}$. . p.57

3.14 Cultura celular realizada em SU-8 liso, HEX-12, HEX-30, HEX-80, HEX280 e HEX-560, quantificados através da contagem de núcleos marcados com DAPI. São apresentados valores médios e barras de erro de três experimentos independentes. . . . . . . . . . . . . . . . p. 58

3.15 Imagem típica da cultura de células marcadas com trypan blue em SU-8 liso. A barra indica $100 \mu \mathrm{m} \ldots \ldots \ldots \ldots \ldots$. . . . . . . . . . . . . . . . . . . .

3.16 Imagem típica da cultura de células marcadas com trypan blue no substrato HEX-12. A barra indica $100 \mu \mathrm{m}$. . . . . . . . . . . . . . . p.60

3.17 Imagem típica da cultura de células marcadas com trypan blue no substrato HEX-80. Os círculos indicam células marcadas e a barra indica medida de

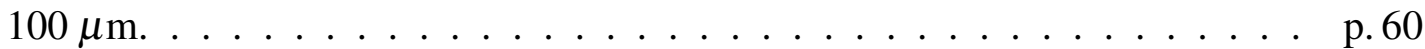

3.18 Imagem típica da cultura de células marcadas com trypan blue no substrato HEX-280. A barra indica $100 \mu \mathrm{m} . \ldots \ldots$. . . . . . . . . . . . 61

3.19 Imagem típica da cultura de células marcadas com trypan blue no substrato HEX-560. A barra indica $100 \mu \mathrm{m} . \ldots \ldots$. . . . . . . . . . . . 61

3.20 Valores médios do número de células vivas por unidade de área para três experimentos independentes realizados sobre superfícies de SU-8 liso e substratos HEX-12, HEX-80, HEX-270 e HEX-560, conforme a tabela 3.3. . . . .

3.21 (a) MO de cultura celular realizada em SU-8 litografado, gerando estruturas periódicas na forma de cavidades hexagonais com parâmetros $2 R=82 \mu \mathrm{m}$, $\beta=37 \mu \mathrm{m}$ e $h=3 \mu \mathrm{m}$. Dessa forma $40 \%$ da superfície da amostra ficou em um nível abaixo do restante dela, sendo o desnível de $3 \mu \mathrm{m}$ (que corresponde ao valor de h). (b) Definição para os parâmetros de produção desta geometria. 
3.22 (a) Exemplo de imagem binarizada.(b) Exemplo de curva obtida para $\operatorname{Cor}(r)$ (linha preta) e o respectivo ajuste, segundo equação 2.20 (linha vermelha). . . p. 64

3.23 Histograma para as distâncias entre os primeiros vizinhos. . . . . . . . p.65

3.24 Histograma para as distâncias entre os segundos vizinhos mais próximos. p.66

3.25 Histograma para as distâncias entre os terceiros vizinhos mais próximos. . . . p.66

A.2 Micrografias MEV de superfícies obtidas para corrente do feixe de elétrons de 15 pA com variação na dose, utilizada na litografia de cavidades hexagonais

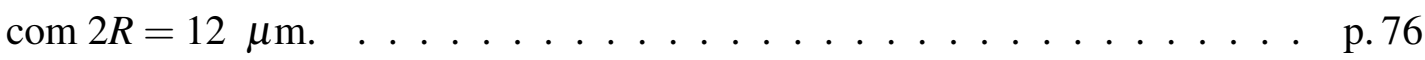

A.4 Micrografias MEV de superfícies obtidas para corrente do feixe de elétrons de 20 pA com variação na dose, utilizada na litografia de cavidades hexagonais

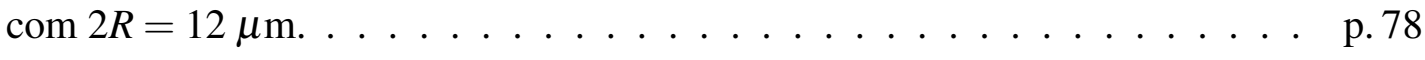

A.5 Micrografia obtida por MEV para microcavidades com $2 R \approx 80 \mu \mathrm{m}$, produzidas com corrente de $15 \mathrm{pA}$ e dose de $0,07 \mathrm{nC} / \mathrm{cm}$. . . . . . . . . . p. 79

B.1 Micrografia MEV de célula CHO no estado inicial de adesão ao material SU-8. p. 80

B.2 Micrografia MEV de diversas células CHO, estando algumas espraiadas, apresentando boa adesão ao material SU-8. Como exemplo, têm-se as medidas $d 1=48 \mu \mathrm{m}, d 2=75 \mu \mathrm{m}, d 3=63 \mu \mathrm{m}$ e $d 4=67 \mu \mathrm{m} . \ldots \ldots \ldots$ p. 81

C.1 Superfície de SU-8 semeada com $6 \times 10^{4}$ células, após as 24 horas de cultura, com os núcleos marcados com fluoróforo DAPI. Essa imagem possui tamanho de $437 \times 328 \mu \mathrm{m}^{2} \ldots \ldots \ldots \ldots \ldots$ p. 83

C.2 Microscopias ópticas típicas das culturas celulares realizadas, após as 24 horas, no material SU-8 onde foi variado o número de células semeadas. . . . . p. p3

C.3 Micrografia da superfície de SU-8 semeada com $1,2 \times 10^{5}$ células, após as 24 horas de cultura, e marcadas com o fluoróforo DAPI. Essa imagem possui tamanho de $437 \times 328 \mu \mathrm{m}^{2} \ldots \ldots \ldots \ldots \ldots$ p. 84

D.1 (a) Padrão contendo 16 circunferências. (b) Padrão contendo 31 circunferências. Estes padrões foram analisados pela função de correlação. . . . . . p. p. 86

D.2 (a) Gráfico para a função de correlação $\operatorname{Cor} r(r)$ calculado para o padrão 1.

(b) Gráfico para a função de correlação $\operatorname{Corr}(r)$ calculado para o padrão 2. . p.86 
D.3 Ilustração de um gráfico de $\operatorname{Corr}(r)$, indicando a região de integração para o cálculo do número médio de partículas aglomeradas $\langle N c\rangle$ para o primeiro pico (primeiros vizinhos) . . . . . . . . . . . . . . . p. 88 


\section{Lista de Tabelas}

2.1 Parâmetros de fabricação obtidos por medidas realizadas em MEV e AFM para a cavidades hexagonais nos diversos diâmetros. A variação das dimensões das amostras foram de $\pm 1 \mu \mathrm{m}$ para $2 R$ e de $\pm 0,5 \mu \mathrm{m}$ para $\beta$ e

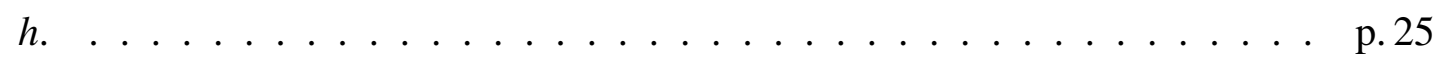

3.1 Energia de superfície e valores médios dos fatores de forma $\left(F_{f}\right)$ de 450 células, para cada uma das culturas realizadas sobre vidro, SU-8, DLC e PDMS sem tratamento prévio e sem a introdução de microestruturas. . . . . . p. p.47

3.2 Valores percentuais dos elementos obtidos pela análise de RBS. . . . . . . . p.51

3.3 Parâmetros de fabricação obtidos por medidas realizadas em MEV e AFM para a cavidades hexagonais nos diversos diâmetros. . . . . . . . . . . p.56

3.4 Células vivas por unidade de área, para três experimentos independentes, para culturas celulares realizadas em amostra microestruturada em SU-8 com geometria periódica na forma de cavidades hexagonais com parâmetros $2 R=$ $82 \mu \mathrm{m}, \beta=37 \mu \mathrm{m} \mathrm{e} h=3 \mu \mathrm{m} . \ldots \ldots \ldots \ldots$ p. 63

3.5 Parâmetros obtidos para o ajuste da função de correlação para os diversos tipos de superfícies litografadas. . . . . . . . . . . . . . . . . p. 67

A.1 Valores obtidos para as dimensões das microcavidades hexagonais através de medidas por AFM. . . . . . . . . . . . . . . . . p. 79

A.2 Valores obtidos para as dimensões das microcavidades hexagonais de $2 R \approx$

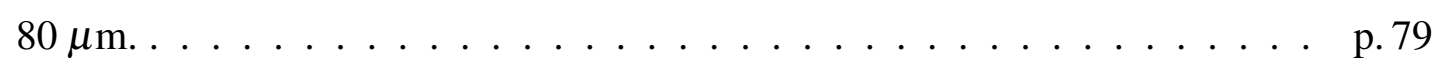




\section{Lista de Abreviaturas}

$A C \quad$ Ângulo de Contato

AFM Atomic Force Microscopy

CAM Contact Angle Measurements

CAD Computer Aided Design

CHO Chinese Hamster Ovary

DLC Diamond-like Carbon

DMSO Dimetilsulfóxido

EDTA Ácido Etilenodiamino Tetra-acético

ES Energia de Superfície

DAPI 4',6-diamidino-2-phenylindole dihydrochloride

DNA Ácido Desoxirribonucleico (deoxyribonucleic acid)

FFT Fourier Fast Transform

FAPESP Fundação de Amparo a Pesquisa do Estado de São Paulo

NPGS Nano Pattern Generation System

ME Matriz Extracelular

MEV Microscopia Eletrônica de Varredura

MEMS Micro Electromechanical Systems 
MO Microscopia Óptica

MePIIID Metal Plasma Immersion Ion Implantation and Depostion

PDMS Poli(dimetil siloxano)

LFF Laboratório de Filmes Finos

IFUSP Instituto de Física da Universidade de São Paulo

SPM Scanning Probe Microscopy

RMS Raiz média quadrática (Root Mean Square)

RBS Rutherford Backscattering Spectrometry

PMMA Poli(metacrilato de metila)

Unesp Universidade Estadual Paulista Júlio de Mesquita Filho

UFRJ Universidade Federal do Rio de Janeiro

TRIM Transport and Range of Ions in Matter

UV Ultravioleta

XRD Difração de Raios-X (X-ray Diffraction) 


\section{Lista de Símbolos}

$E_{i} \quad$ Energia Final dos íons;

$V_{\text {ext }}$ Tensão externa aplicada nas grades de extração;

$V_{p l} \quad$ Potencial elétrico do plasma;

$V_{c h} \quad$ Potencial elétrico da câmara de implantação;

$Q \quad$ Estado de carga;

$e \quad$ Carga elementar do elétron

$x \quad$ Coordenada $\mathrm{x}$ do plano cartesiano;

y Coordenada y do plano cartesiano;

$\beta \quad$ Largura da parede da microcavidade;

$h \quad$ Altura da microcavidade;

$2 R$ Diâmetro do círculo inscrito na microcavidade;

$A, B e C$ Regiões da câmara de Neubaeur;

$E_{1} \quad$ Energia do projétil após colisão;

$E_{0} \quad$ Energia do projétil antes da colisão;

Z Número atômico;

K Fator cinemático;

$M_{1} \quad$ Massa do projétil; 
$M_{2} \quad$ Massa do alvo;

$\gamma_{S L}$ Tensão superficial da interface sólido líquido;

$\gamma_{S V}$ Tensão superficial da interface sólido vapor;

$\gamma_{L V} \quad$ Tensão superficial da interface líquido vapor;

$\gamma^{p} \quad$ Componente polar da tensão superficial;

$\gamma^{d} \quad$ Componente dispersiva da tensão superficial;

$\Theta \quad$ Ângulo de contato;

$\Theta_{A} \quad$ Ângulo de avanço;

$\Theta_{R} \quad$ Ângulo de recesso;

W Trabalho;

F Módulo da Força;

$F_{f} \quad$ Fator de forma;

$k \quad$ Constante de mola;

$x \quad$ Deflexão do cantiléver;

$\operatorname{Corr}(r)$ Função de correlação;

$f(x, y)$ Função de $x$ e $y$;

$f^{*}(x, y)$ Complexo conjugado de $f(x, y)$;

$r \quad$ Coordenada $r$ do sistema polar;

$\rho \quad$ Densidade de partículas;

$\rho^{2} N$ Fator de normalização;

A Constante de normalização;

$r c \quad$ Raio de aglomerado;

dc Distância entre aglomerados;

$N_{p} \quad$ Número de primeiros vizinhos; 
$\left\langle N_{c}\right\rangle$ Número médio de partículas aglomeradas;

$N_{T} \quad$ Número total de partículas; 


\section{Resumo}

O projeto de novos materiais para aplicações tecnológicas em biomateriais e bioengenharia é altamente dependente de como as células aderem à superfície de um material. A adesão e crescimento em biomateriais depende de propriedades do substrato, tais como molhabilidade da superfície, a topografia e a composição química de superfície. O objetivo deste estudo foi investigar as interações de diversos materiais com culturas celulares de células epitelial $\mathrm{CHO}$ (Ovário de Hamster Chinês).

Os materiais utilizados foram SU-8 2005 (elétron-resiste, Microchem), PDMS (Poli (dimetil siloxano), Down Corning), DLC (Diamond-like Carbon) e o vidro foi utilizado como referência. Superfícies de vidro, SU-8, PDMS e DLC lisas (planas) e isentas de modificação ou tratamento específico foram avaliadas quanto ao cultivo de células $\mathrm{CHO}$. Valores médios dos fatores de forma $\left(F_{f}\right)$ de 450 células foram calculados para cada uma das culturas realizadas sobre os 4 substratos. Foram obtidos $F_{f}$ próximos a 0,52 para o vidro, o SU-8 liso e o DLC, demonstrando um bom espraiamento das células nessas superfícies. A superfície de PDMS apresentou valor unitário para o fator de forma $\left(F_{f}\right)$, que está relacionado a um baixo espraiamento das células. A energia de superfície (ES) obtida para o PDMS é compatível com o resultado do fator de forma $\left(F_{f}\right)$, uma vez que o menor valor para ES é coerente com a baixa adesão celular, o que gerou células com elevado fator de forma $\left(F_{f}\right)$.

O SU-8 foi modificado por implantação iônica com uma dose de $1,2 \times 10^{16}$ átomos $/ \mathrm{cm}^{2}$ e a energia de implantação foi de $8 \mathrm{keV}$, como referência foi utilizada uma superfície lisa de SU-8 sem implantação. Os resultados mostraram que o número de células vivas por unidade de área foi superior na superfície de SU-8 com prata implantada, mostrando o bom desempenho da cultura nesse substrato.

As superfícies de DLC modificadas por tratamento com plasma de oxigênio (DLC-O) e com plasma de hexafluoreto de enxofre (DLC-F) foram utilizadas para cultura celular, os resultados de três experimentos independentes de contagem de número de núcleos (marcados com DAPI) por unidade de área confirmaram os resultados obtidos através do teste de viabilidade (marcados com trypan blue). A superfície de DLC-O, apresentou um maior número de núcleos por unidade de área, quando comparado à superfície DLC-F, da mesma forma que nos resultados obtidos pelo teste de viabilidade. As energias de superfície para as amostras de DLC-F e DLC-O indicaram que a superfície DLC-O é mais hidrofílica do que a superfície DLC-F, que está coerente com o que é conhecido da literatura e com os resultados obtidos em nosso trabalho. 
Cultura de células $\mathrm{CHO}$ foram realizadas em superfícies litografadas com estruturas hexagonais periódicas com o parâmetro $2 R$ (diâmetro do círculo inscrito) sendo $12 \mu \mathrm{m}, 30 \mu \mathrm{m}$, $80 \mu \mathrm{m}, 280 \mu \mathrm{m}, 560 \mu \mathrm{m}$ e também em SU-8 liso. Estas superfícies foram caracterizadas por microscopia óptica de fluorescência com relação ao número de núcleos (marcados com o fluoróforo DAPI) por unidade de área, isto é, núcleos $/ \mathrm{mm}^{2}$. Obteve-se histogramas com o número médio de núcleos por $\mathrm{mm}^{2}$ em três experimentos independentes, onde o número núcleos $/ \mathrm{mm}^{2}$ foi consideravelmente maior para $80 \mu \mathrm{m}$. As superfícies contendo cavidades periódicas de $12 \mu \mathrm{m}$ e $30 \mu \mathrm{m}$ apresentaram dificuldade para as células $\mathrm{CHO}$ aderirem à superfície.

Em uma outra etapa realizou-se culturas celulares em triplicata dos substratos com as superfícies $12 \mu \mathrm{m}, 80 \mu \mathrm{m}, 280 \mu \mathrm{m}, 560 \mu \mathrm{m}$ e também em SU-8 liso. As células em cada uma das superfícies foram analisadas por microscopia óptica (MO) para avaliação da viabilidade celular, utilizando marcador trypan blue. Obteve-se histogramas com os valores médios para o número de células vivas $/ \mathrm{mm}^{2}$ para as culturas celulares que corrobora os resultados obtidos no histograma da cultura celular que tiveram os núcleos marcados pelo fluoróforo DAPI. Assim, fica confirmado o melhor desempenho da cultura celular no substrato $80 \mu \mathrm{m}$ que apresentou o maior número de células vivas $/ \mathrm{mm}^{2}$

As micrografias obtidas através de marcação por DAPI foram analisadas através da função de correlação com intuito de se entender como as células estavam organizadas. Isso foi feito para cada uma das superfícies litografadas, $12 \mu \mathrm{m}, 30 \mu \mathrm{m}, 80 \mu \mathrm{m}, 280 \mu \mathrm{m}, 560 \mu \mathrm{m}$ e também em SU-8 liso. As superfícies dos substratos $80 \mu \mathrm{m}$ apresentaram os menores valores de distâncias para primeiros e segundos vizinhos, ou seja, as células estão mais próximas umas das outras. As demais superfícies tendem a separar mais as células. Obteve-se também os valores de raio de aglomerado $\left(r_{c}\right)$, distância entre os aglomerados $\left(d_{c}\right)$ e o número de primeiros vizinhos $\left(N_{p}\right)$ através do ajuste da função de correlação. A análise de correlação mostrou com clareza o que não era evidenciado apenas visualizando-se as imagens. Ela mostra que as células, mesmo em SU-8 liso tem a forte tendência de formar aglomerados de células com raio de aproximadamente $\sim 45 \mu \mathrm{m}$.

No caso de substratos lisos, células CHO apresentaram a melhor adesão na superfície do SU-8, seguido do DLC, enquanto que o PDMS foi a pior situação, devido à baixa molhabilidade do material. No caso de superfícies com microestrutura, SU-8 contendo microcavidades hexagonais de 12 e $30 \mu \mathrm{m}$ mostraram ser as situações mais adversas para o crescimento de células $\mathrm{CHO}$, provavelmente por causa da topografia das cavidades serem de menor tamanho quando comparadas ao tamanho das células CHO. Em vez disso, SU-8, contendo microcavidades hexagonais de $80 \mu \mathrm{m}$ foi a superfície mais favorável para o crescimento de células $\mathrm{CHO}$.

Palavras-chave: Modificação de Superfícies, DLC, SU-8, PDMS, células CHO, Microfabricação. 


\section{Abstract}

The design of new materials for technological applications in biomaterials and bioengineering is highly dependent on how the cells adhere to the material surface. The cells adhesion and growth on biomaterials depends on substrate properties such as surface wettability, topography and the chemical composition. The aim of this study was to investigate the interactions of various materials with cell cultures of epithelial cells CHO (Chinese Hamster Ovary).

The materials used were SU-8 2005 (electron resists, Microchem), PDMS (poly (dimethyl siloxane), Dow Corning), DLC (Diamond-like Carbon) and glass was used as reference. Unmodified and flat surfaces of glass, SU-8, PDMS and DLC were evaluated for the culture of CHO cells. Form factor $\left(F_{f}\right)$ values were calculated as average of 450 cells for each of the cultures performed on the four substrates. $F_{f}$ close to 0.52 was obtained for flat surfaces of glass, SU- 8 and DLC, showing a good cell spreading on these surfaces. The surface of PDMS presented a form factor $\left(F_{f}\right)$ near unity, which is related to low spreading cell. The surface energy (ES) obtained for the PDMS is coherent with the $F_{f}$ result, since the smallest value of ES is consistent with the low cell adhesion, which resulted in cells with a high $F_{f}$.

The SU-8 was modified by ion implantation using a dose of $1.2 \times 10^{16}$ atoms $/ \mathrm{cm}^{2}$ and an implantation energy of $8 \mathrm{keV}$, unmodified flat SU-8 was used as a reference. The cell culture results showed that the number of live cells per unit area was greater in the SU-8 surface implanted with silver, showing a good performance in the culture substrate.

The DLC surfaces modified by plasma treatment with oxygen (DLC-O) and sulfur hexafluoride (DLC-F) were used for cell culture. The results of three independent experiments, counting the number of nuclei (marked with DAPI) per unit area, confirmed the results obtained by the viability test (marked with trypan-blue). The surface of the DLC-O had higher number of nuclei per unit area when compared to the surface of the DLC-F, similarly to the results obtained for the viability test. The surface energies of the DLC-F and DLC-O samples indicated that the DLC-O surface is more hydrophilic than the DLC-F surface, which is consistent with results obtained with our work and with the literature.

$\mathrm{CHO}$ cell culture were performed on surfaces with periodic hexagonal structures with the diameter of inscribed circle ( $2 R$ ) given by $12 \mu \mathrm{m}, 30 \mu \mathrm{m}, 80 \mu \mathrm{m}, 280 \mu \mathrm{m}, 560 \mu \mathrm{m}$ and also on flat SU-8. These surfaces were characterized by fluorescence optical microscopy with respect to the number of nuclei (marked with fluorophore DAPI) per unit area, i.e. nuclei $/ \mathrm{mm}^{2}$. Histograms were obtained for the average number of nuclei per $\mathrm{mm}^{2}$ in three independent experiments, where the substrate with periodic hexagonal structures with $2 R=80 \mu \mathrm{m}$ presented 
considerably higher nuclei $/ \mathrm{mm}^{2}$. Surfaces containing periodic cavities of $2 R=12 \mu \mathrm{m}$ and $30 \mu \mathrm{m}$ were adverse for $\mathrm{CHO}$ cells adhesion.

In another approach, cell culture were analyzed by light microscopy (LM) for evaluation of cell viability using trypan-blue marker. This was carried out in triplicate cell culture on substrates with surfaces $12 \mu \mathrm{m}, 80 \mu \mathrm{m}, 280 \mu \mathrm{m}, 560 \mu \mathrm{m}$ and also on flat SU-8. Histograms were generated for average number of living cells $/ \mathrm{mm}^{2}$ for each substrate, which corroborates with the results obtained for the cell culture marked with fluorophore DAPI. Thus, it is confirmed the better performance of the cell culture on substrates with $2 R=80 \mu \mathrm{m}$, presenting the highest number of living cells $/ \mathrm{mm}^{2}$.

The micrographs obtained with cells marked with DAPI were analyzed through the correlation function with the aim of understanding how the cells were organized. This was performed for each of the lithographed surfaces $12 \mu \mathrm{m}, 30 \mu \mathrm{m}, 80 \mu \mathrm{m}, 280 \mu \mathrm{m}, 560 \mu \mathrm{m}$ and also flat SU-8. The surfaces of the substrates with $2 R=80 \mu \mathrm{m}$ had the lowest values for length between its neighbors, that is, the cells are closer to each other. The remaining surfaces tend to separate the cells. Also were obtained the cluster radius values $\left(r_{c}\right)$, the distance between the clusters $\left(d_{c}\right)$ and the number of nearest neighbors $\left(N_{p}\right)$ through the correlation function fitting. The correlation analysis clearly showed what was not possible to observe by viewing the images. It shows that the cells, even in flat SU-8, have a strong tendency to form clusters of cells within about 45 micrometers.

In the case of flat substrates, $\mathrm{CHO}$ cells exhibited better adhesion to the surface of SU-8, followed by the DLC, while the PDMS was worse due to low wettability of the material. In the case of surfaces with microstructures, SU-8 containing hexagonal microstructures of 12 and $30 \mu \mathrm{m}$ showed to be the most adverse conditions for the CHO cell growth, probably because of the topography of the cavities being smaller in size compared to the size of CHO cells. SU-8 with $80 \mu \mathrm{m}$ hexagonal microstructures was more favorable surface for the growth of CHO cells.

Keywords: Surface modification, DLC, SU-8, PDMS, CHO cell, Microfabrication. 
$\Gamma_{\text {Capítulo } 1}$

\section{INTRODUÇÃO}

\subsection{Colocação do Problema.}

Existem muitos materiais comuns e de baixo custo, tais como polímeros, que não são tóxicos e são estáveis com relação às propriedades mecânicas (como elasticidade) e à resistência a degradação, que poderiam ser favoráveis para o uso biomédico. Contudo, um problema importante que ainda remanesce em nossos dias é a inadequada interação entre um determinado material (polímeros, metais e cerâmicas) e as células. O uso de um material sem os devidos requisitos para adesão celular leva o organismo a reconhecê-lo como um corpo estranho, causando reações in vivo tal como inflamações, infecções, soltura asséptica, resíduos de tecidos locais, bem como trombose. O projeto de novos materiais para aplicações tecnológicas em biomateriais e bioengenharia é altamente dependente de como as células aderem a superfície de um material.

Adesão celular é um tema de extrema importância, como pode-se observar da figura 1.1. Vemos que o assunto move uma grande sinergia da comunidade científica com cerca de 1 milhão de publicações no período de 2000 a 2014 para se tentar desvendar os mecanismos que atuam na adesão celular. No entanto, quando a mesma questão é tratada do ponto de vista da adesão celular aos materiais SU-8, DLC (diamond-like carbon) e ao PDMS (Poli (dimetil siloxano)) temos apenas cerca de 5000, 7000 e 15000 publicações, respectivamente, no mesmo período (ver figura 1.2). Isso representa cerca de $0,5 \% ; 0,7 \%$ e $1,5 \%$ de todas a publicações sobre este assunto que têm sido publicadas no mesmo período para SU-8, DLC e PDMS, respectivamente. Configura-se que adesão celular é um assunto no qual há bastante interesse científico e que tem muito a ser explorado, considerando-se que trabalhamos com os materiais que foram supracitados. 


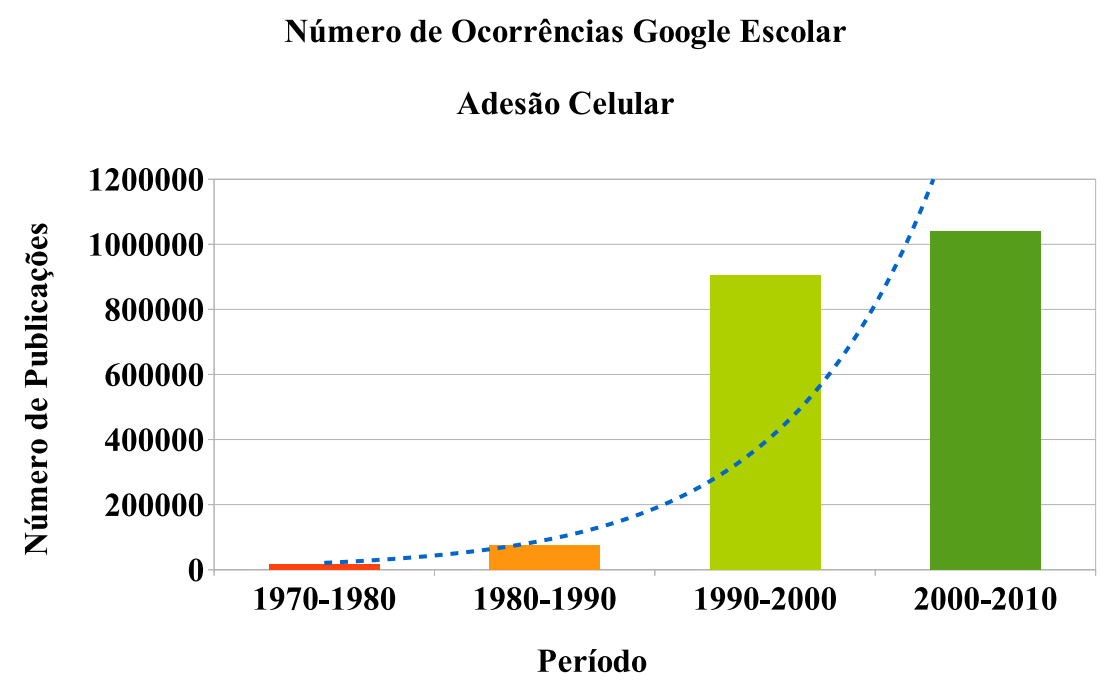

Figura 1.1: Número de publicações nos últimos 40 anos encontrados no google escolar acerca do assunto adesão celular. A linha pontilhada é referente a tendência de crescimento.

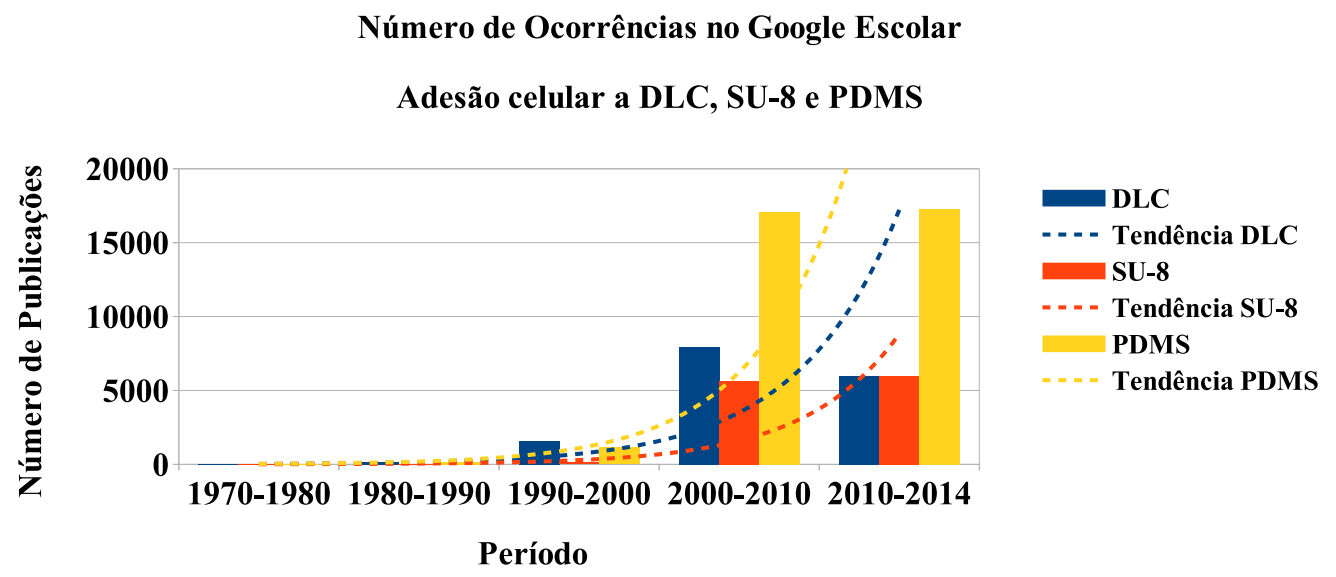

Figura 1.2: Número de publicações nos últimos 40 anos encontrados no google escolar acerca do assunto adesão celular e relacionando com DLC, SU-8 e PDMS. A linha pontilhada é referente a tendência de crescimento. 


\subsection{Motivação.}

O Laboratório de Filmes Finos (LFF) vem trabalhando em diferentes projetos que fazem uso de técnicas de modificação de superfície. Uma das técnicas refere-se a um projeto, já encerrado, visando à obtenção de superfícies superhidrofóbicas coordenado pela Prof ${ }^{\mathrm{a}}$. $\operatorname{Dr}^{\mathrm{a}}$. Maria Cecília Salvadori (processo FAPESP número 06/07306-4) [1-3]. Uma segunda técnica consiste de modificação de superfícies por plasma e sua caracterização por Scanning Probe Microscopy, já encerrado, coordenado pelo Prof. Dr. Mauro Cattani (processo FAPESP número 08/09979-1) $[4,5]$.

A fixação e a proliferação de células de mamíferos são fortemente influenciadas pela química de uma superfície $[6,7]$. Na ausência de ligantes de superfície, a energia livre de superfície é fortemente correlacionada com a taxa de adesão celular. É conhecido que as superfícies de alta energia promovem adesão celular e o rápido espraiamento das células no substrato, enquanto que, superfícies de baixa energia não favorecem esse tipo de comportamento [7, 8].

A introdução de microestruturas em substratos para cultura celular pode levar à dificuldade de fixação das células, o que deve impedir seu desenvolvimento local. Assim, com diferentes padrões em uma mesma superfície, o desenvolvimento de culturas celulares poderá ser planejado em áreas seletivas. O tratamento por plasma modifica química e fisicamente a superfície [9]. Mais estritamente, esse tratamento pode criar terminações contendo átomos específicos na superfície do material, alterando diversas propriedades como energia de superfície e o seu potencial elétrico $[4,5]$.

\subsection{Relevância do ponto de vista tecnológico.}

Os processos utilizados para a fabricação de dispositivos de estado sólido não foram necessariamente projetados para serem compatíveis com os delicados sistemas biológicos e bioquímicos e muitos deles não foram otimizados para criar estruturas relevantes para uso biomédico. Com a diversidade de sistemas biológicos e a vasta quantidade de materiais bioquímicos, existe uma motivação e um desafio de desenvolvimento e padronização de métodos apropriados para reunir em um só contexto essas áreas de conhecimento [10].

A modificação de superfície tem sido largamente utilizada em materiais que devem manter contato com células vivas [11-16]. Tratamentos químicos [17-26] ou utilizando plasma [2737] são os mais usados, apresentando consideráveis alterações das propriedades da superfície. Os materiais para aplicações biomédicas podem ser poliméricos [8, 38-40], metálicos [41-43], 
cerâmicas bioativas [44-47] e mais recentemente tem sido realizado crescimento de células em geis [48-51]. Estes materiais podem ser empregados em uma vasta variedade de aplicações tecnológicas, como exemplo pode-se citar: usos na indústria de cosméticos [52], impressão 3D de material vivo [53-59], crescimento de células em géis para tratamento de feridos [53, 60, 61] e implante dentário [38, 54, 62-64].

Mas apesar disso, ainda há uma grande demanda por outros materiais [40]. Tal como, na engenharia de tecidual em que há uma necessidade por substratos transparentes para monitoramento e obtenção de informações histológicas dos tecidos enquanto estão em crescimento [56]. O sucesso ou o fracasso dos implantes dentários está diretamente relacionado ao grau de integração do material do implante aos tecidos circundantes versus a formação de uma camada bacteriana (biofilme) [63]. Existe ainda a necessidade de materiais para encapsulamento e criação de um micro ambiente contendo células enquanto as mesmas são testadas com relação a administração de uma determinada medicação $[65,66]$.

A escolha dos materiais para este estudo foi baseado nas suas propriedades e aplicações. SU-8 é uma base epóxi, sensível ao feixe de elétrons (elétron-resiste) e a radiação UV (U1travioleta), que pode ser litografado, por feixe de elétrons e fotolitografogado por UV. O SU8 pode ser utilizado em uma variedade de aplicações, especialmente utilizando técnicas de microfabricação [67], como microfluidos [68], superhidrofobia [1-3] e bio-MEMS (Micro Electromechanical Systems) [69]. Nanopartículas de prata são conhecidas por sua propriedades antibacterianas $[70,71]$. Como é sabido, a implantação iônica de metal em polímero promove a formação de nanopartículas dentro do polímero [72-79]. O PDMS (Poli(dimetil siloxano)) é um material polimérico amplamente utilizado com várias características interessantes, que incluem alta flexibilidade, transparência óptica, biocompatibilidade e facilidade para fabricação [8, 71, 80-82]. Diamond-Like Carbon (DLC) é um material de carbono amorfo com alto teor de ligações sp3, fornecendo propriedades semelhantes às de filmes de diamante, sendo também um material biocompatível. As aplicações biomédicas do DLC são geralmente em recobrimento de implante em articulações para redução do desgaste [83-85].

\subsection{Cultura de células em superfícies modificadas.}

Cultura de células é um processo complexo pelo qual células são crescidas com nutrientes e condições apropriadas, geralmente fora do seu ambiente natural. Quando realizada num laboratório, o processo é chamado de "Cultura de Células". A cultura celular pode ser estabelecida a partir de células animais. No entanto, existem também culturas de células originadas de plan- 
tas, fungos e microorganismos, incluindo vírus, bactérias e os protistas ${ }^{1}$. O processo de cultura permite que as células individuais possam agir como unidades independentes, bem como um micro-organismo tal como uma bactéria ou fungo. As células são capazes de se dividir, aumentarem seu tamanho e, em um lote de cultura, pode continuar a crescer até serem limitadas por alguma variável da cultura, tais como a depleção de nutrientes.

Culturas normalmente contêm células de um tipo, embora culturas mistas, especialmente de bactérias, sejam comuns em Ciências dos Alimentos e estudos relacionados com tratamento de águas residuais. As células em cultura podem ser geneticamente idênticas (população homogênea) ou pode mostrar alguma variação genética (população heterogênea). Uma população homogênea de células derivadas de uma única célula parental é chamado um clone. Por conseguinte, todas as células dentro de uma população clonal são geneticamente idênticas [86].

Apesar dos primeiros estudos datarem de 1911 [87-90], o cultivo de células animais só começou a se desenvolver com sucesso na década de 1950 [91-94], quando H. Eagle conseguiu definir os nutrientes necessários para o crescimento celular. Basicamente, um meio para o cultivo de células animais inclui água, sais minerais, aminoácidos, vitaminas, glicose, suplementos orgânicos (proteínas, peptídeos, piruvatos e lipídios), soro fetal de cavalo, bovino ou humano (fatores de crescimento) e antibióticos (para prevenir as contaminações microbianas). As células devem ser isoladas e mantidas assepticamente em condições bastante estritas de temperatura $\left(35^{\circ}\right.$ a $\left.37^{\circ} \mathrm{C}\right), \mathrm{pH}$, concentração de $\mathrm{CO}_{2}$ e umidade. A cultura de células apresenta uma série de vantagens com relação ao uso de espécimes vivos (cobaias) e o cultivo in vivo, dentre elas podemos citar [95, 96]:

- Possibilidade de estudar fenômenos inacessíveis em tecidos intactos;

- Controle das condições ambientais (pH, temperatura, concentração de $\mathrm{O}_{2}$ e $\mathrm{CO}_{2}$ );

- Obtenção de células com boa homogeneidade e bem caracterizadas;

- Economia de reagentes, tempo;

- Conhecimento de comportamento e função de uma população isolada de células.

Entretanto, a principal vantagem do uso de cultura de células é a consistência e reprodutibilidade dos resultados que podem ser obtidos utilizando um lote de células clonais. A desvantagem é que, após um período de crescimento contínuo, características celulares podem mudar e podem tornar-se bastante diferentes daqueles encontrados na população de partida [95]. Existe

\footnotetext{
${ }^{1}$ Os protistas são as algas unicelulares e os protozoários. A célula de um protista é semelhante às células de animais e plantas, mas há particularidades.
} 
um grande número de sistemas celulares que permitem o cultivo em laboratório e em escala industrial de células animais. Os fatores limitantes da maioria dos sistemas de cultivo celular são oxigenação, superfície de crescimento (no caso de células aderentes), disponibilidade de nutrientes e presença de metabólitos tóxicos. No geral, os processos de cultivo celular podem ocorrer, de acordo com o tipo de célula utilizado, com as células estando aderentes ou em suspensão. Células animais são, na sua maioria, naturalmente aderentes, tendo em vista a sua procedência tecidual [86, 95-99]. As culturas de células que são isoladas diretamente de um organismo são denominadas de culturas de células primárias, as quais são caracterizadas por um período de vida médio limitado. Uma cultura primária torna-se uma linhagem celular quando é transferida para um novo frasco/placa. A linhagem de células finitas é uma cultura capaz de se dividir por um número limitado de vezes. Por sua vez, linhagem de células contínuas é uma cultura que tem acumulado as mudanças genéticas necessárias para crescimento ilimitado in vitro [86, 96] e são conhecidas como células transformadas ou imortalizadas. Em sistemas de cultivo de células aderentes, estas aderem a uma superfície, se espalham e proliferam. A proliferação ocorre na forma de camada, onde as células crescem sobre a superfície até formarem uma monocamada celular. Neste ponto diz-se que a cultura alcançou a confluência. Culturas primárias, possuem um sistema de proliferação que é inibido pelo contato intercelular [86, 96]. Desta forma, sua proliferação cessa ao se formar a monocamada celular. No entanto, células imortalizadas perdem este sistema de controle proliferativo, podendo formar multicamadas de células. No entanto, é possível crescer culturas primárias além do ponto de inibição por contato, utilizando regimes de troca de meio, suplementos (tais como soro), aminoácidos, glicose, fosfatases, fatores de crescimento, hormônios, entre outros $[86,96]$. O ciclo celular é composto por diversas etapas, dentre elas podemos citar a fase em que as células estão mais saudáveis apresentando um grande número de divisões, sem perder as características da população de partida. Nesta fase as células estarão em crescimento exponencial $[96,100]$. A adesão e o espraiamento de células aderentes sobre uma superfície apropriada são resultados de forças físicas e de adesão exercidas por moléculas presentes na membrana celular $[8,86,97,101]$. O meio de cultura exerce forte influência no fenômeno de adesão, sendo o $\mathrm{pH}$ e a força iônica do meio de cultura fatores importantes na aderência celular $[8,86,96,97,100]$.

\subsubsection{A célula.}

As células são os elementos mais básicos dos seres humanos, animais ou plantas, sendo a menor unidade estrutural, capaz de existir de maneira independente e se reproduzir, conforme a figura 1.3. A células foi descoberta em 1665 pelo inglês Robert Hooke, o mesmo da lei de 
Hooke. O cientista utilizou o termo célula para designar as pequenas cavidades de um pedaço de cortiça, tecido vegetal morto, observadas por ele com um microscópio.

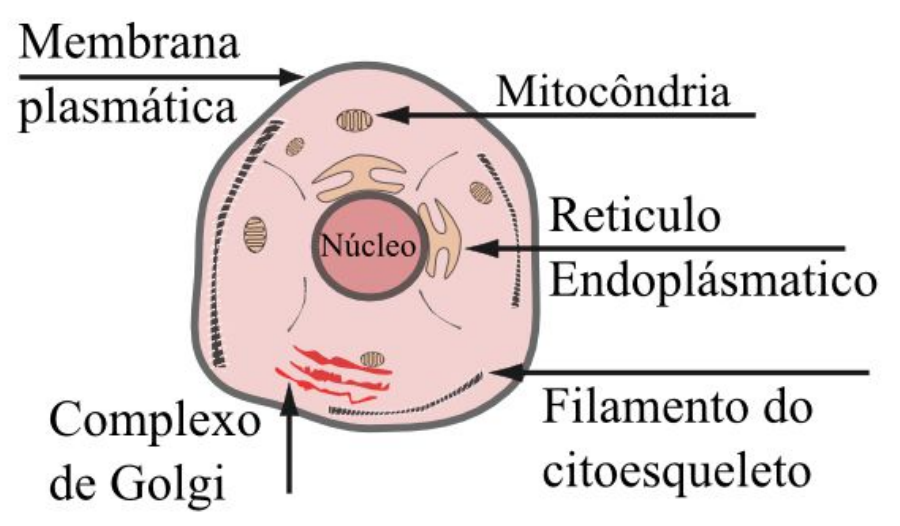

Figura 1.3: A célula e algumas de suas organelas.

Na maioria dos seres vivos, as células aparecem, de forma nítida, divididas em três partes: membrana plasmática, citoplasma e núcleo. A membrana envolve e protege a célula, além de regular a entrada e saída de substâncias (permeabilidade seletiva). No citoplasma, porção mais volumosa, ocorrem os organoides, estruturas com funções específicas, como é o caso de: retículo endoplasmático (transporte de substâncias), ribossomos (síntese de proteínas), complexo de Golgi (secreção celular), lisossomos (digestão celular), mitocôndrias (produção de energia) e ainda várias outras. O núcleo contém o material genético, representado pelo DNA, a partir do qual, direta ou indiretamente, acontecem todas as reações celulares [100, 102].

Células in situ, dentro de órgãos ou tecidos, estão incorporadas em um micro ambiente altamente estruturado. O micro ambiente da célula, isto é, a matriz extracelular (ME) e as células vizinhas, impõe condições de contorno específicas que influenciam não só a arquitetura celular mas também a mecânica, a polaridade e a função da célula. $O$ tamanho do micro ambiente limita o volume e o espraiamento das células, sua estrutura, ou seja, o posicionamento de células adjacentes e a localização. A orientação das fibras da ME, dita as distribuições espaciais dos pontos de aderência das celulas, são os pontos focais de adesão (focal adhesion) [101, 102].

A composição bioquímica e a rigidez do micro ambiente especificam os fatores que podem estar envolvidos na adesão celular e, assim, afetam vias intra-celular de sinalização, como apresentado na figura 1.4. Estas vias subsequentemente ditam a montagem e dinâmica das redes do citoesqueleto. Além de ter um papel na configuração da organização intra-celular, o micro ambiente celular também influencia a expressão dos genes e a diferenciação celular. Portanto, as propriedades do micro ambiente são cruciais para a regulação das funções celulares [101, 102]. 


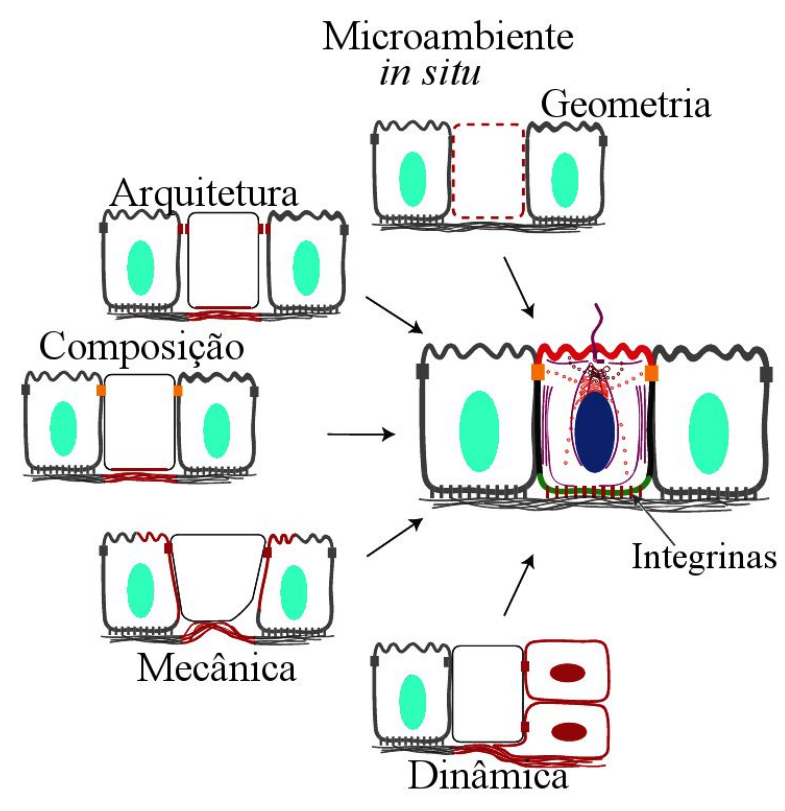

Figura 1.4: A célula e as suas respostas com relação ao micro ambiente. Figura adaptada de [101].

As integrinas são receptores trans-membranares que se ligam às proteínas da ME aos filamentos de actina intracelular. Quando as células entram em contato com a ME, elas mudam sua forma e há a propagação de um processo de várias etapas. Umas destas etapas é a adesão das células propriamente dita [101]. A adesão se dá pela formação de protuberâncias da membrana plasmática, seguido da extensão da membrana da célula, e a formação das fibras internas de contração que estimulam ainda mais pontos de ligação da membrana celular a ME, este processo se dará até que toda a extensão da membrana celular esteja ancorada a ME, por alguns pontos [101].

\subsubsection{Células e as escalas de tamanhos.}

As células diferem de acordo com a sua função no organismo e também do ambiente em que está imersa, tal como ocorre em um organismo multicelular. Um exemplo somos nós humanos, em que podem existir cerca de 100 a 216 tipos diferentes de células. Estas células atuam cooperativamente e são hierarquicamente organizadas em tecidos, órgãos e sistemas orgânicos multicelulares. Nos tecidos estão contidas as células somadas a outros materiais, tais como a matriz extracelular secretada pelas células. Diversos tecidos podem funcionar juntos compondo um órgão. Por fim, um conjunto de órgãos podem formar um organismo [102-104].

As células com estruturas e funções similares agrupam-se para formar tecidos. Apesar da impressionante diversidade de tipos e funções de células, há realmente apenas cinco tipos 
principais de tecido, sendo eles; epitelial, conjuntivo, muscular, nervoso e sanguíneo. Tecidos epiteliais são geralmente células delicadas que formam revestimentos de estruturas e órgãos internos. Elas também formam o revestimento externo de nossos corpos, nossa pele. Os tecidos conjuntivos são encontrados nas paredes dos órgãos onde eles fornecem suporte estrutural. Ossos, cartilagens, ligamentos e tendões são exemplos de tecido conjuntivo. O tecido muscular permite que o corpo se mova e este caracteriza-se por sua capacidade de se contrair. $\mathrm{O}$ tecido nervoso é composto por células altamente especializadas chamadas neurônios, e caracterizase pela sua capacidade de traduzir um estímulo eletroquímico em impulsos nervosos. A região entre as células de um tecido é igualmente importante. Muitas vezes, é denominado a Matriz Extracelular (ME) e que contém proteínas e íons que executam funções vitais [86]. A ME pode ser entendida como sendo um tecido segregado pelas células capaz de suportar as tensões mecânicas [102]. Por fim, temos o sangue que pode ser visto como um tecido conjuntivo líquido, produzido na medula óssea vermelha, flui pelas veias, artérias e capilares sanguíneos. O sangue é responsável pelo transporte de substâncias tais como: nutrientes, oxigênio, gás carbônico e toxinas, e também pela regulação e proteção de nosso corpo [102].

O tecido epitelial tem como função o revestimento de órgãos e cavidades. As células epiteliais apresentam um bom crescimento em cultura. Ao atingir a confluência é formada uma monocamada de células que têm à aparência similar a ladrilhos em uma calçada conforme apresentado na figura 1.5. Células de tecido epitelial apresentam um comprimento típico de cerca de 25 a $50 \mu \mathrm{m}$.

Tipos de epitélio

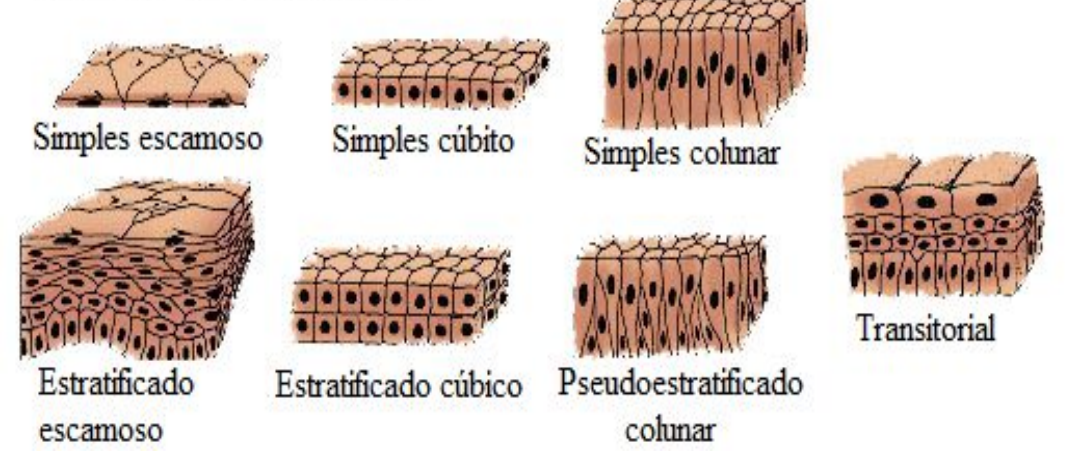

Figura 1.5: Esquema ilustrativo da organização celular do sistema epitelial.

Nos tecidos conjuntivos as células mais comuns de serem encontradas sãos os fibroblastos. Quando estes estão aderidos a uma superfície em cultura celular podem ter um comprimento da ordem de 50 a $100 \mu \mathrm{m}$. Os fibroblastos têm como função secretar a ME [102]. 
O tecido muscular consiste de uma série de túbulos formados a partir de células precursoras que se fundem para formar um complexo multinucleado. As células precursoras são os mioblastos, que são capazes de diferenciação para formar miotubos, um processo que pode ser observado na cultura. As células musculares são altamente elongadas, seu diâmetro típico em seu estado relaxado é da ordem de $5-6 \mu \mathrm{m}$, enquanto que seu comprimento é de $200 \mu \mathrm{m}$ [102-104].

O tecido nervoso é composto por neurônios. Os neurônios são compostos por uma parte central chamada soma, essa região tem um diâmetro de $10-80 \mu \mathrm{m}$, onde o núcleo está localizado e é o principal local de síntese de proteínas. A extensão do corpo da célula neuronal é chamada de axônio. Geralmente os axônios podem ter alguns mícron de diâmetro e o comprimento de um axônio pode variar de poucos milímetros no cérebro, chegando a ter comprimento da ordem de metro para os grandes neurônios do sistema motor [102-104].

Por fim, mas não menos importante, temos as células do sistema sanguíneo e linfático que contêm células em suspensão. Como exemplo, pode-se citar os leucócitos que são os glóbulos brancos do sangue e são utilizados extensivamente em cultura por causa da sua capacidade para secretar compostos para imunorregulação. Os glóbulos brancos tem de 8 a $20 \mu \mathrm{m}$ de diâmetro, enquanto que os glóbulos vermelhos tem uma forma bicôncava e diâmetro de cerca de 6 a $8 \mu \mathrm{m}$ [102-104].

Neste trabalho foi utilizada a linhagem CHO-K1 (Chinese Hamster Ovary cells) obtida do Banco de Células da Universidade Federal do Rio de Janeiro (UFRJ). A linhagem de células epitelial CHO-K1 é do tipo de ancoragem dependente e imortalizadas que gentilmente foi cedida pela Prof ${ }^{\mathrm{a}}$ Dr $^{\mathrm{a}}$ Daisy M. F. Salvadori ao Laboratório de Filmes Finos. Estas células quando em cultura apresentam tamanhos típicos variando de 15 a $20 \mu \mathrm{m}$ quando pouco aderidas e tamanhos da ordem de 40 a $75 \mu \mathrm{m}$ quando as mesmas se encontram espraiadas.

\subsubsection{Apoptose versus Necrose.}

Apoptose ou morte celular programada é um processo essencial para manutenção do desenvolvimento dos seres vivos, que envolve ativação de genes específicos e subsequente síntese de novas proteínas, as quais participam da execução do programa de morte [105, 106]. A apoptose é, na realidade, um processo controlado geneticamente, que atua na remoção de células indesejáveis, cujo processo está envolvido tanto em funções fisiológicas quanto patológicas [106]. Durante a apoptose as células sofrem alterações morfológicas características, que são observadas em consequência de uma cascata de eventos moleculares e bioquímicos específicos. Entre estas alterações podemos destacar a retração da célula, alteração da integridade da membrana 
plasmática, perda de aderência com a matriz extracelular e células vizinhas e picnose nuclear $[98,99]$.

A necrose é considerada uma morte acidental, consistindo de um processo não fisiológico, no qual são observadas mudanças na morfologia. As células sofrem alterações na forma e função das mitocôndrias e rapidamente tornam a célula incapaz de manter a homeostase celular interna, resultando no aumento do volume celular, agregação da cromatina, desorganização do citoplasma, perda da integridade da membrana plasmática e por fim ruptura celular. Em geral, a apoptose se diferencia da necrose por não ocorrer extravasamento de material citoplasmático, por apresentar uma fragmentação do DNA controlada e uniforme [105, 106]. Através do teste de viabilidade celular é possível identificar células mortas, por necrose e/ou apoptose.

\subsection{Objetivos.}

O principal objetivo deste estudo foi investigar a interação de células vivas, em termos de adesão e crescimento, com as superfícies de materiais tecnologicamente interessantes.

De acordo com essa proposta os objetivos podem ser descritos da seguinte maneira:

\section{Superfícies lisas.}

Quando feito modificação de superfície, alterando as propriedades das mesmas, fizemos a avaliação das diferentes superfícies com relação ao número de celulas por unidade de área nas superfícies dos substratos:

DLC puro;

DLC contendo terminações de superfície de oxigênio;

DLC contendo terminações de superfície de flúor;

SU-8 puro;

SU-8 com nanopartículas de prata geradas por implantação iônica.

Nosso objetivo foi investigar: quando os materiais com as superfícies lisas; tivessem sua superfície modificada por tratamento a plasma e implantação iônica, qual seria o desempenho da cultura de células (células $/ \mathrm{mm}^{2}$ ) realizada neste substratos?

\section{Superfícies Microfabricadas.}

Quando feito a microfabricação fizemos a escolha dos tamanhos das microcavidades que foi baseado na ordem de grandeza dos tamanhos das células indo desde a situação em que 
estas se encontram pouco aderidas, até a situação em que as células estão espraiadas. Para tal, produziu-se superfícies litografadas com estruturas periódicas hexagonais litografadas. O parâmetro a ser variado foi o diâmetro do círculo inscrito $(2 R)$ nestas estruturas o que gerou diferentes tamanhos de $2 R$, podemos enumerar estas superfícies como sendo:

SU-8 liso;

SU-8 com estruturas periódicas hexagonais com parâmetro $2 R$ de $12 \mu \mathrm{m}$;

SU-8 com estruturas periódicas hexagonais com parâmetro $2 R$ de $30 \mu \mathrm{m}$;

SU-8 com estruturas periódicas hexagonais com parâmetro $2 R$ de $80 \mu \mathrm{m}$;

SU-8 com estruturas periódicas hexagonais com parâmetro $2 R$ de $280 \mu \mathrm{m}$;

SU-8 com estruturas periódicas hexagonais com parâmetro $2 R$ de $560 \mu \mathrm{m}$.

Nesse caso, o questionamento principal foi: como essas escalas podem interferir no comportamento de adesão e espraiamento das células quando as mesmas são semeadas nas superfícies microfabricadas?

\subsection{Organização do trabalho.}

Na seção de "Materiais e Métodos", faremos a descrição dos procedimentos de produção bem como das análises das amostras. Logo na sequência são apresentados os "Resultados e Discussão"onde apresentaremos os resultados obtidos e a discussão dos mesmos. Por fim, são apresentadas as "Conclusões"do nosso trabalho e as "Perspectivas de trabalhos futuros". 


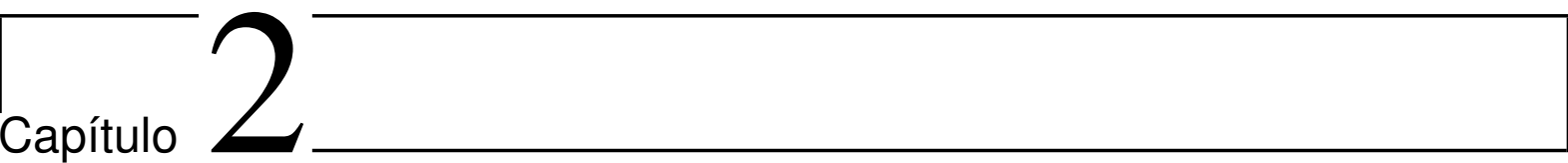

\section{MATERIAIS E MÉTODOS.}

Nas próximas seções passaremos à descrição dos processos e caracterizações envolvidas neste trabalho iniciando pela produção das superfícies de SU-8 2005, DLC e PDMS. Uma vez produzidas, estas superfícies foram modificadas ou por tratamento a plasma, ou implantação iônica ou introdução de microestruturas periódicas através da litografia por feixe de elétrons. Na sequência, descreveremos a cultura de células nestas diversas superfícies e por fim falaremos sobre as técnicas de caracterização do desempenho da cultura de células em tais superfícies.

\subsection{Fabricação das superfície lisas.}

Neste trabalho fizemos a escolha de alguns materiais que foram analisados pelo desempenho da cultura de células em sua superfície. Deste modo, primeiramente foram estudados os materiais com as suas superfícies originalmente depositadas, SU-8 2005, DLC e PDMS, ou seja, sem qualquer espécie de tratamento. Depois modificamos as superfícies de DLC introduzindo terminações de superfície de flúor ou oxigênio através do tratamento a plasma $[4,5]$, gerando as amostras que definiremos como sendo DLC-F e DLC-O, respectivamente. As superfícies de SU-8 foram modificadas pela implantação iônica de prata gerando as superfícies que definiremos como sendo SU-8/Ag. Todos as amostras que após a modificação de superfície permaneceram planas, definiremos como superfícies lisas.

\section{Preparação do substrato de silício.}

Os substratos utilizados para a deposição de SU-8 e DLC foram lâminas de silício $\{100\}$ da Silicon Sense do tipo N com dimensões de 3 polegadas de diâmetro e espessura de 0,3 à 
0,35 mm. As lâminas de silício foram cortadas em peças menores, nas dimensões de $17 \times$ $17 \mathrm{~mm}^{2}$ utilizando uma ponta de diamante. Fizeram-se necessárias duas etapas de limpeza e uma etapa de secagem das peças menores de silício:

\section{Limpeza Mecânica:}

- Friccionou-se a lâmina com algodão embebido em acetona por 5 minutos;

- Friccionou-se com algodão embebido em álcool isopropílico por 5 minutos.

\section{Limpeza em agitação ultrassônica:}

- 5 minutos em acetona;

- 5 minutos em álcool isopropílico.

\section{Secagem}

Após a agitação ultrassônica em álcool isopropílico, cada peça foi submetida a $3000 \mathrm{rpm}$ durante 30 s no spinner (um prato giratório de altas velocidades e grande estabilidade mecânica). Em seguida a lâmina foi imediatamente colocada na placa quente já pré-aquecida a $200{ }^{\circ} \mathrm{C}$ durante 30 minutos. Ao final destas etapas as lâminas de silício estavam livres de material particulado e impurezas orgânicas. No decorrer do texto nos referiremos as peças cortadas e limpas, por uma questão de simplicidade, como sendo lâminas de silício.

\section{Superfícies de SU-8 2005.}

A lâmina de silício foi colocada no porta amostra de um spinner, presa por vácuo, e através de gotejamento foi recoberta completamente com SU-8 2005 da Micro Chem Corp. O equipamento foi programado para executar uma velocidade angular de $4000 \mathrm{rpm}$ durante um tempo de $50 \mathrm{~s}$. A lâmina de silício recoberta com SU-8 2005 foi pré-tratada termicamente em placas quentes pelos tempos de 1 minuto a $65{ }^{\circ} \mathrm{C}$ e 2 minutos a $95^{\circ} \mathrm{C}$. Após o pré-tratamento a lâmina foi exposta à luz ultravioleta $(350 \mathrm{~nm}$ a $400 \mathrm{~nm})$ em uma câmara expositora de ultravioleta construída inteiramente no Laboratório de Filmes Finos [1-3]. O tempo de exposição do elétron-resiste a luz ultravioleta foi de 3 minutos. Após a exposição, a lâmina é aquecida novamente em placa quente por 1 minuto a $65^{\circ} \mathrm{C}, 2$ minutos a $95^{\circ} \mathrm{C}$ e 1 minuto finalizando a deposição. Deste modo, uma camada de filme com superfície plana e uniforme de aproximadamente $3 \mu \mathrm{m}$ de espessura em SU-8 2005 recobre completamente a lâmina de silício. 


\section{Superfícies de PDMS.}

A produção do PDMS (Silgard 184, Dow Corning) foi realizada a partir do desmolde de uma superfície de SU-8 2005, que neste caso, atua como molde. A polimerização do PDMS inicia-se com a mistura de uma base (silicone) e um catalisador que é seu agente de cura na proporção de 1/10. A mistura destes materiais foi feita manualmente utilizando espátula e bastão de vidro o que inevitavelmente gera bolhas de ar na mistura final. Para solucionar este problema o material foi colocado numa câmara de vácuo durante 15 minutos. Nesta condição as bolhas de ar são removidas completamente em uma pressão da ordem de $\sim 75$ Torr. O PDMS livre de bolhas de ar foi então depositado sobre um substrato liso da amostra de SU-8 2005 liso de modo a recobrir toda a sua superfície. Em seguida para concluir a etapa de endurecimento do $P D M S$, a amostra contento SU-8 liso e recoberta com $P D M S$ foi aquecida a $150{ }^{\circ} \mathrm{C}$ durante 20 minutos em placa quente. Para realizarmos o desmolde fizemos a aplicação prévia de um surfactante, com nome comercial Tween 20 da Sigmma Aldrich, sobre a amostra de SU-8 2005 e esperou-se a secagem por 15 minutos. Foi usado uma concentração de $9,8 \times 10^{-5} \mathrm{~mol} / \mathrm{L}$ de surfactante em água. $\mathrm{O}$ desmolde foi realizado em água dissolvendo o surfactante no processo, liberando a superfície de PDMS intacto da superfície de SU-8 liso [8, 71, 80, 81].

\section{Fabricação do Filme Diamond-Like Carbon (DLC).}

O depósito de DLC foi realizado no equipamento MePIIID (Metal Plasma Immersion Ion Implatation and Deposition), construído inteiramente no Laboratório de Filmes Finos [107]. O sistema consiste de uma câmara de vácuo e um canhão de plasma. O canhão de plasma (ver Figura 2.1) é formado por um catodo no formato de bastão, feito do material do qual se deseja obter o filme, envolto em uma capa cerâmica dentro de um anodo cilíndrico de aço inoxidável. Um gatilho dispara uma descarga pulsada entre catodo e anodo, provocando um faiscamento distribuído aleatoriamente na superfície do catodo (cathode spots), gerando o plasma de seu material. O anodo é passivo, agindo como um coletor de elétrons. A corrente de arco do plasma é da ordem de 200 A, com duração do arco de $5 \mathrm{~ms}$. O plasma é então focalizado por um campo magnético axial gerado por uma bobina enrolada no próprio anodo, em série com a descarga elétrica entre catodo e anodo. Ainda em série com essa descarga vem o filtro de partículas que consiste de uma bobina enrolada na forma de um tubo metálico curvado como um quarto de toroide.

Assim a corrente de descarga passa por essa bobina, gerando um campo típico de $10 \mathrm{mT}$ em seu centro. O plasma é guiado por este campo até o substrato posicionado na saída do filtro de partículas. As micropartículas, também ejetadas do catodo, terão trajetórias praticamente 


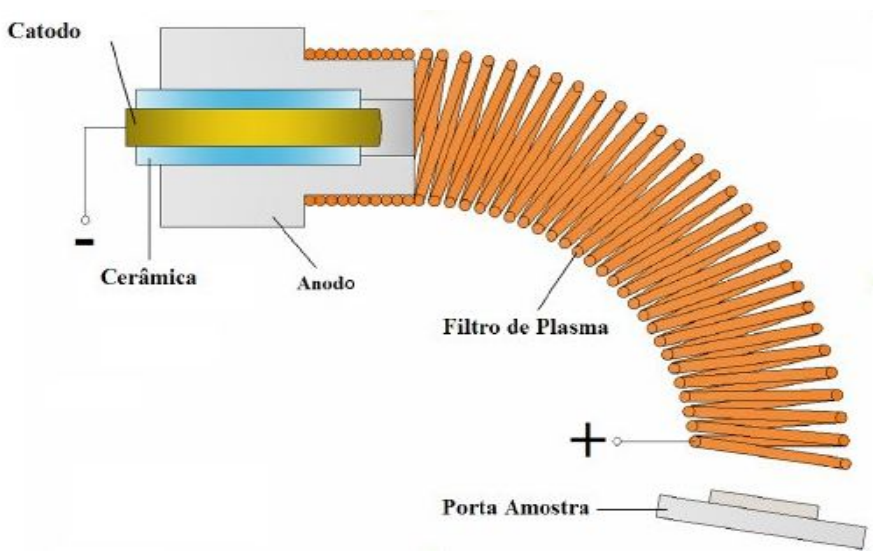

Figura 2.1: Esquema ilustrativo da montagem do canhão de plasma.

retas devido à sua grande inércia, chocando-se com as paredes do filtro ou da câmara. Assim, a deposição do filme ocorre livre de contaminação dessas micropartículas, com excelente homogeneidade e alta pureza [107, 108].

Através desta técnica é possível depositar filmes finos de diversos materiais, incluindo diamond-like carbon (DLC) livre de hidrogênio. Para a deposição dos filmes de DLC o canhão de plasma foi montado com um catodo de grafite de alta pureza, permitindo depósito de DLC livre de hidrogênio e de excelente qualidade. Um filme fino de DLC de aproximadamente $30 \mathrm{~nm}$ de espessura foi depositado sobre lâmina de silício, previamente limpa, com bias pulsado de -100 V aplicado ao substrato de silício [109-112]. A distância entre a amostra e a saída do filtro de partículas foi de $7 \mathrm{~cm}$ e taxa média de deposição de $0,04 \mathrm{~nm} /$ pulso.

\subsection{Modificação de Superfície.}

A modificação das superfícies lisas (planas) foi realizada por duas técnicas de processamento, sendo estas, tratamento por plasma e implantação iônica. Nas próximas seções descreveremos estes processos utilizados para a modificação das superfícies.

\subsubsection{Tratamento por plasma.}

Modificação de superfície por plasma de baixa temperatura pode ser produzida por uma descarga elétrica a baixa pressão. Plasma consiste do quarto estado da matéria e possui características específicas, mas normalmente é constituído de uma mistura de espécies altamente reativas, isto é, íons, radicais, elétrons, fótons e moléculas excitadas. A sua composição química e características físicas são determinados, em adição ao gás usado, pelos parâmetros do disposi- 
tivo, tais como a geometria da câmara, a taxa de fluxo de gás, a tensão e corrente usadas na descarga. Este método é usado para modificar a composição química e morfologia de superfícies de materiais a uma profundidade de até algumas dezenas de microns, assim deixando a maior parte das propriedades de bulk praticamente intactas. Assim, pode ser obtido uma composição química de superfície completamente diferente, alterando por exemplo, a molhabilidade e a rugosidade da superfície [113].

Os filmes de DLC que foram depositados por MePIIID como já descrito, tiveram suas superfícies tratadas por plasma. O tratamento consiste em gerar superfícies de DLC com terminações de flúor ou oxigênio utilizando um canhão de plasma do tipo hollow cathode [114].

\section{Modificação da Superfície do DLC com plasma de $S F_{6}$.}

O tratamento de superfícies por plasma [4-6], foi realizado utilizando um canhão de plasma denominado hollow-cathode plasma gun (ver Figura 2.2) [114]. Esse equipamento tem sido utilizado no LFF até o momento com dois tipos de gás: oxigênio ou hexafluoreto de enxofre $S F_{6}$ [4-6], o que permite a oxidar e fluorar as superfícies.

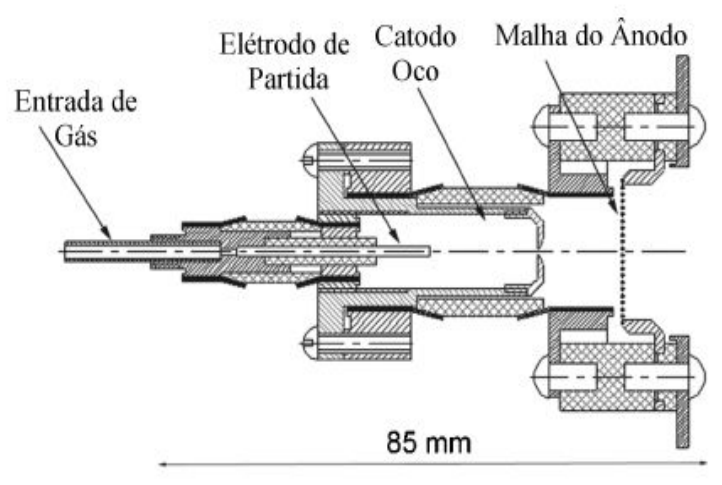

Figura 2.2: Ilustração esquemática do canhão de plasma de catodo oco.

Utilizou-se o gás hexafluoreto de enxofre $S F_{6}$ para fluorar as superfícies de $D L C$. O canhão de plasma hollow cathode foi operado com uma tensão de -800 a $-850 \mathrm{~V}$, corrente de descarga em torno de $10 \mathrm{~mA}$, uma pressão de base de $7,5 \times 10^{-3}$ Torr e a amostra localizada a $15 \mathrm{~mm}$ a frente do catodo. O tempo de exposição ao plasma de $S F_{6}$ foi de 7 minutos. Na figura 2.3 é apresentado o canhão de plasma em operação. 


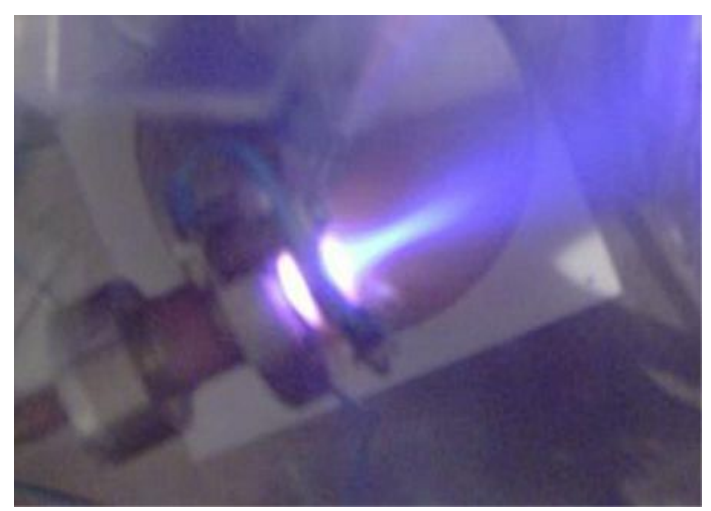

Figura 2.3: Canhão de plasma (hollow-cathode plasma gun) em operação com o gás $S F_{6}$.

\section{Modificação da superfície de DLC com plasma de oxigênio.}

A oxidação da superfície de DLC, foi realizada no mesmo canhão de plasma hollow cathode. Para o tratamento utilizou-se os seguintes parâmetros: Tensão de $-750 \mathrm{~V}$ a $-800 \mathrm{~V}$, pressão de base de $2,0 \times 10^{-4}$ Torr, distância da amostra ao catodo foi de $120 \mathrm{~mm}$, tempo de exposição ao plasma de 5 minutos e foi registrada uma corrente de $30 \mathrm{~mA}$ no canhão de plasma durante o tratamento. Na figura 2.4 é apresentado a imagem da amostra enquanto estava exposta ao plasma de oxigênio.

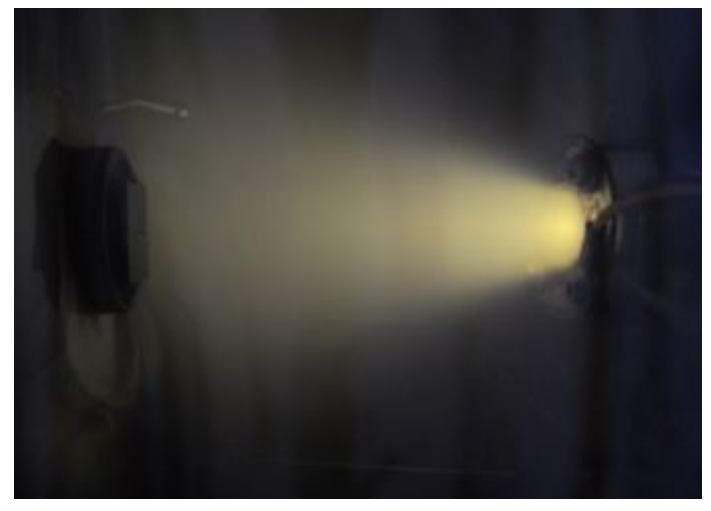

Figura 2.4: Canhão de plasma em operação com o gás $\mathrm{O}_{2}$.

\subsubsection{Implantação iônica.}

A implantação iônica pertence a uma classe de processos de feixes iônicos onde átomos ou moléculas são ionizados, acelerados em um campo elétrico e implantados em um material alvo. A coexistência de espécies químicas diversas (não necessariamente em equilíbrio) e a transferência da energia dos íons para o sólido provocam modificações estruturais e/ou químicas no material, alterando propriedades mecânicas, elétricas, supercondutoras, ópticas e magnéticas. 
Tais modificações são fortemente dependentes do material alvo e dos parâmetros de bombardeamento: energia cinética dos íons, fluência, corrente do feixe, espécie iônica utilizada como projétil e temperatura da amostra durante o bombardeamento [108, 115-117].

Para implantação iônica foi utilizado plasma de arco catódico pulsado como fonte de íons. O canhão de plasma foi montado com um catodo de prata, gerando o plasma deste material. Ao sair do canhão, o plasma é guiado pelo filtro de partículas até a região da primeira grade aterrada do implantador, como mostrado na figura 2.5. A fonte de alimentação do canhão de plasma consiste de um circuito $L C R$ de impedância de $1 \Omega$ e duração de pulso de $100 \mu \mathrm{s}$, fornecendo uma corrente de centenas de ampères a uma taxa de repetição de 3 pulsos por segundo.

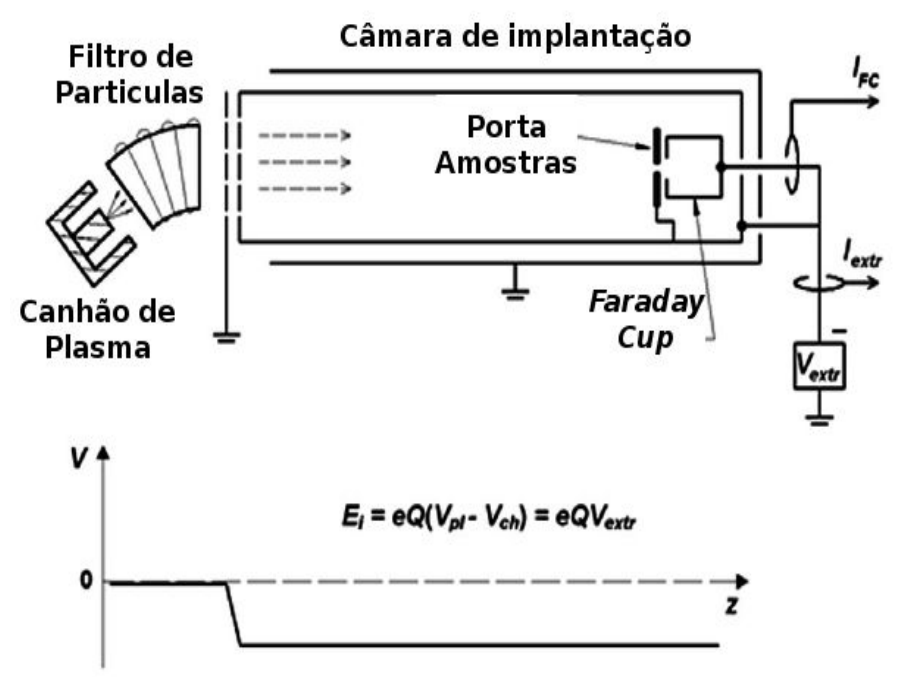

Figura 2.5: Na figura temos o esquema simplificado do sistema de implantação iônica. Em $E_{i}=e Q V_{e x t}$, têm-se que $E_{i}$ é a energia final dos íons, $e$ a carga do elétron, $Q$ o estado de carga dos íons, e $V_{e x t}=V_{p l}-V_{c h}$ é a queda de tensão no extrator, $V_{p l}$ é o potencial do plasma e $V_{c h}$ é o potencial da câmara.

Os eletrodos de formação do feixe de íons (grade de extração) são a abertura para a câmara de implantação para o qual os íons são direcionados, ver figura 2.5. Na figura 2.6 apresenta-se uma visão de corte do implantador em que um cilindro externo foi mantido aterrado e sustenta a primeira grade de entrada do plasma. Um cilindro interno, que estava eletricamente isolado do cilindro externo, foi mantido a uma alta tensão negativa conforme a figura 2.6. Esse cilindro interno sustenta a segunda grade extratora, por onde entra o plasma. Assim, um feixe de íons foi formado e acelerado a partir do plasma através das grades extratoras e foi injetado para dentro do cilindro mantido em alta tensão negativa, em direção a um copo de Faraday e ao portaamostras. O copo de Faraday também foi mantido na mesma alta tensão negativa do cilindro interno, mas era eletricamente isolado dele. Na entrada do copo de Faraday foi colocado um par de ímãs permanentes de cobalto samário (com ferro doce confinando o retorno das linhas 
de campo) que gera um campo magnético transverso. Esse campo magnético age como uma barreira para os elétrons do feixe, permitindo a entrada apenas dos íons no copo de Faraday. Este projeto de copo de Faraday é conhecido por fornecer uma medição confiável de corrente de íons do feixe, que foi monitorada por um transformador de corrente bem isolado [118, 119].

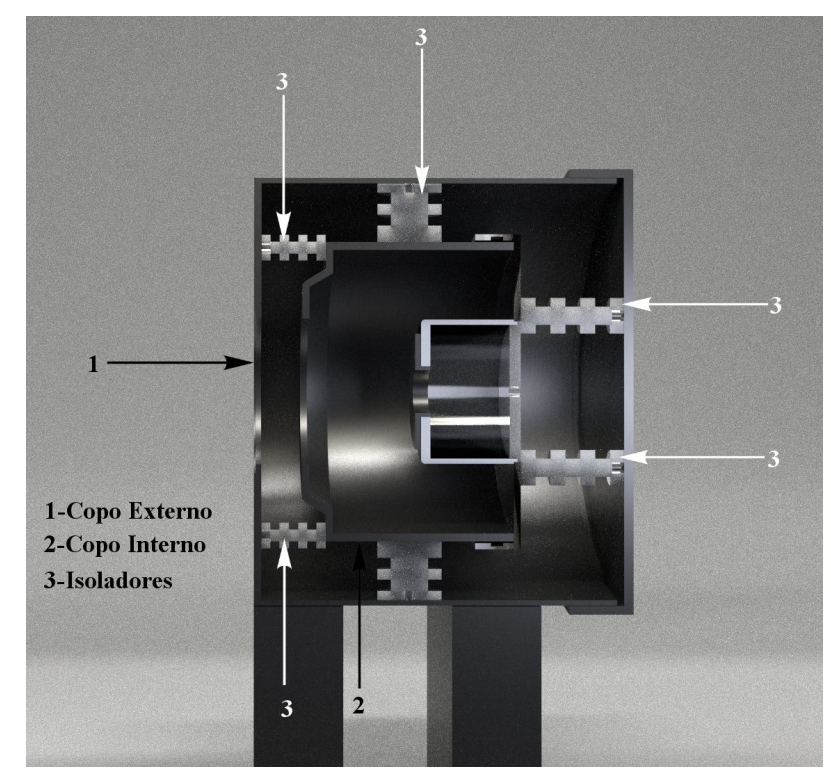

Figura 2.6: Visão em corte do implantador em 3D.

Para modificação do material SU-8 utilizamos uma tensão de extração de $4 \mathrm{kV}$ negativos aplicados em um plasma de prata. A alta tensão de aceleração dos íons é gerada por uma fonte comercial de DC Spellman SL $300(50 \mathrm{kV}, 3 \mathrm{~mA})$. Ressalta-se que o plasma do metal formado na descarga de arco catódico, em geral, contém espécies com múltipla ionização. A energia do feixe de íons é determinada pela queda de tensão através do qual os íons estão sujeitos no extrator, e pelo estado de carga de íons: $E_{i}=e Q V_{\text {ext }}$, onde $E_{i}$ é a energia final dos íons, $e$ a carga do elétron, $Q$ o estado de carga dos íons, e $V_{e x t}$ é a queda de tensão no extrator. Para um plasma de prata, o estado médio de carga dos íons é $Q=2[108,120]$. Assim, a energia média dos íons de prata foi de $8 \mathrm{keV}$. A dose planejada foi de $1,2 \times 10^{16}$ átomos $/ \mathrm{cm}^{2}$.

\subsubsection{Simulação numérica realizada no código TRIDYN.}

Foram realizadas simulações numéricas para as implantações iônicas utilizando o programa TRIDYN, que fornece o perfil esperado para a distribuição dos átomos implantados no substrato. O TRIDYN [121, 122] é um programa de simulação de Monte Carlo baseado no TRIM (Transport and Range of Ions in Matter) [123] que leva em conta mudanças na composição do alvo devido aos átomos já implantados e ao sputtering de material da superfície do substrato. 
Assim, o TRIDYN deve ser utilizado, em substituição ao TRIM, quando a composição do substrato é alterada significativamente durante o processo de implantação, o que ocorre com altas doses, como foi o caso deste trabalho.

\subsection{Superfícies Microfabricadas.}

Definiremos como superfícies microfabricadas as amostras em que, após um processo de litografia, estruturas de geometria definida na escala micrométrica tenham sido geradas em sua superfície.

\subsubsection{Fabricação de microcavidades em SU-8.}

A matéria-prima utilizada na microfabricação através de litografia por feixe de elétrons são polímeros denominados elétron-resistes. Esses polímeros são quimicamente modificados quando atingidos pelo feixe de elétrons. Os elétrons-resistes são geralmente classificados como positivos ou negativos.

Quando são usados elétron-resistes positivos, as áreas expostas ao feixe de elétrons tornamse muito mais solúveis em uma solução química reveladora do que as áreas não expostas. De modo que as regiões sensibilizadas são completamente dissolvidas, e portanto removidas (ver figura 2.7). As demais regiões permanecem praticamente intactas no tempo de revelação. Um exemplo de elétron resiste positivo é o PMMA (Poli (metacrilato de metila)).

Quando são utilizados os elétron-resistes negativos, as áreas expostas ao feixe tornam-se insolúveis à solução química reveladora, permanecendo após o processo de revelação (ver figura 2.7). Um exemplo desta classe de resistes é o SU-8, muito utilizado quando se deseja obter estruturas com alta razão de aspecto $[67,124,125]$. Em nosso caso foi escolhido o SU-8 2005 da Micro Chem Corp, o qual após ser depositado na superfície de silício, atinge espessuras de camada da ordem de 3 a $5 \mu \mathrm{m}$. O processo de litografia é formado por um conjunto de etapas além daquela específica de transferência dos padrões. O processo vai desde a aplicação do elétron-resiste na amostra até a caracterização dos padrões obtidos.

\section{Deposição da primeira camada de SU-8 2005.}

Para produzir as amostras com microcavidades em SU-8 2005, dividimos o processo em duas etapas. Na primeira etapa foi criada uma base lisa de SU-8 e na segunda foram geradas as cavidades também em SU-8. 


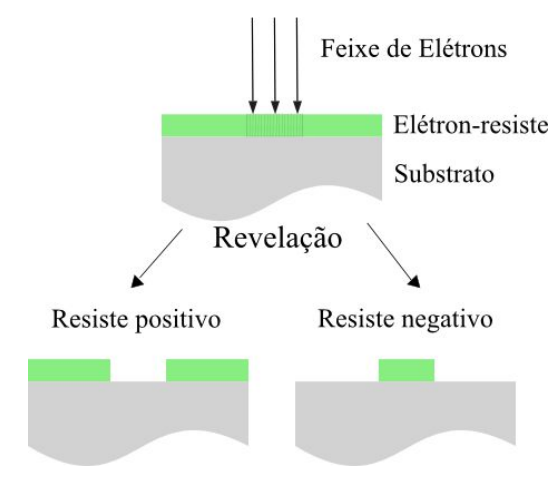

Figura 2.7: Ilustração mostrando a diferença entre elétron-resistes positivos e negativos.

Na primeira etapa, retirou-se a lâmina de silício que permaneceu a $200{ }^{\circ} \mathrm{C}$ por 30 minutos da placa quente como descrito na seção 2.1. Aguardou-se cerca de 1 minuto para o seu resfriamento, mas ainda permanecendo aquecida. A lâmina foi colocada no porta amostra de um equipamento spinner, presa por vácuo, e através de gotejamento foi recoberta completamente com SU-8 2005. Um programa foi executado, o qual comanda o equipamento para executar uma velocidade angular de $4000 \mathrm{rpm}$ durante um intervalo de $50 \mathrm{~s}$. Na sequência, a lâmina de silício recoberta com SU-8 2005 foi aquecida em placas quentes pelos tempos de 1 minuto a $65^{\circ} \mathrm{C}$ e 2 minutos a $95^{\circ} \mathrm{C}$. A lâmina recoberta com SU-8 foi exposta à luz ultravioleta (comprimento de onda de 350 a $400 \mathrm{~nm}$ ) em uma câmara expositora de ultravioleta construída inteiramente no Laboratório de Filmes Finos [1-3]. O tempo de exposição do elétron-resiste a luz ultravioleta foi de 3 minutos. Deste modo, uma camada de superfície plana e uniforme de aproximadamente $3 \mu \mathrm{m}$ de espessura em SU-8 2005 recobre completamente a lâmina de silício. Após a exposição, a lâmina foi aquecida em placa quente por 1 minuto a $65^{\circ} \mathrm{C}, 2$ minutos a $95^{\circ} \mathrm{C}$ e 1 minuto a $200{ }^{\circ} \mathrm{C}$.

Como sequência foi depositada uma segunda camada de SU-8 2005 a ser litografada, como será descrito a seguir. A razão para serem usadas duas camadas de SU-8 se baseia na ideia de microfabricar cavidades em um único material. Caso não houvesse a primeira camada de SU-8, a base da cavidade seria em silício, contrariando a proposta inicial.

\section{Deposição da segunda camada de SU-8 2005.}

De modo semelhante ao utilizado na produção da primeira camada, a lâmina de silício recoberta com SU-8 2005 foi colocada no porta amostra do spinner, presa por vácuo, e recoberta completamente com SU-8 2005 novamente. O equipamento foi acionado para executar uma velocidade angular de $4000 \mathrm{rpm}$ durante um tempo de $50 \mathrm{~s}$. Seguindo, a lâmina de silício recoberta com uma segunda camada uniforme de SU-8 2005 foi aquecida em placas quentes 
pelos tempos de 1 minuto a $65^{\circ} \mathrm{C}$ e 2 minutos a $95^{\circ} \mathrm{C}$. A amostra foi levada a um microscópio eletrônico de varredura (MEV) (Jeol 6460 LV), com acessório para nanolitografia, e um padrão pré-estabelecido foi transferido para a superfície da amostra através de sensibilização por feixe de elétrons $[4,5]$.

\section{Sistema de geração de padrões.}

Acoplado ao MEV temos um sistema gerador de padrões o NPGS (Nanometer Pattern Generation System) que controla as bobinas de varredura através de computador e software dedicados. Esta ferramenta permite reproduzir desenhos de padrões pré-definidos sobre a superfície de uma amostra, em escala micro ou nanométrica, utilizando o feixe de elétrons de MEV. As coordenadas $(x, y)$ do desenho são transformadas em comandos que controlam um interruptor do feixe (beam blanking) e as bobinas de varredura do microscópio, manipulando-os de forma que o feixe de elétrons reproduza as coordenadas $(x, y)$ do desenho sobre a superfície da amostra para a geração do padrão [126, 127].

\section{Geração de padrões.}

Os padrões são gerados em um software tipo CAD (Computer Aided Design). O formato e dimensões do padrão dependerão da estrutura que se pretende fabricar. Como etapa seguinte, uma amostra de calibração (veja apêndice 5) deve ser desenhada e transferida sobre silício recoberto com o resiste para a determinação correta dos parâmetros. Na Figura 2.8 tem-se um exemplo de padrão de dimensões projetadas de $89,0 \mu \mathrm{m} \times 154,1 \mu \mathrm{m}$, consistindo de uma célula unitária para ser repetidamente transferida para a superfície utilizando o feixe de elétrons. A célula unitária é definida com sendo a menor unidade a ser transferida para a superfície.

\section{Transferência de padrões.}

A amostra foi levada ao microscópio eletrônico de varredura, que possui acessório para nanolitografia, e um padrão pré-estabelecido foi transferido para a superfície da amostra através de sensibilização por feixe de elétrons. Os parâmetros obtidos a partir de um processo de calibração da litografia, podem ser listados como:

Dose de 0,05 e $0,07 \mathrm{nC} / \mathrm{cm}$,

Distância centro a centro de cada ponto do feixe de $50 \mathrm{~nm}$,

Distância entre centros de linhas adjacentes 500 nm, 

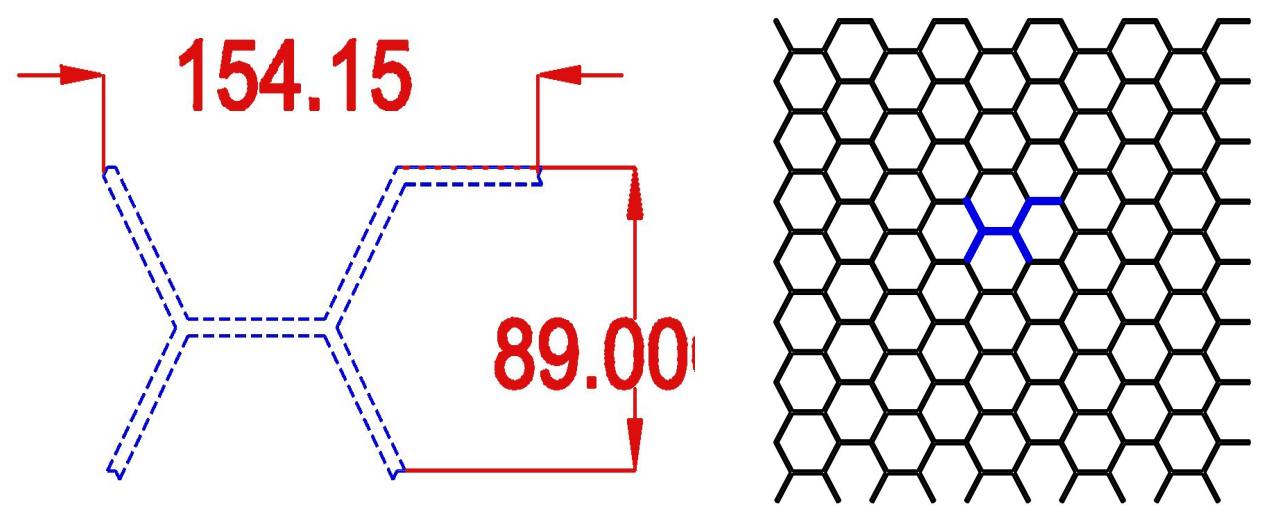

Figura 2.8: Na esquerda temos um exemplo de célula unitária para produção de um array por feixe de elétrons gerando uma área litografada de $8 \times 8 \mathrm{~mm}^{2}$, medida na figura em microns. $\mathrm{Na}$ direita temos um exemplo de array construído a partir da célula unitária.

Aumento do microscópio cerca de 11 vezes,

Corrente do feixe de 30 a 50 pA.

\section{Revelação do SU-8.}

Terminada a transferência do padrão para a superfície, a amostra foi retirada do MEV e levada para a placa quente a $65,0 \pm 0,1^{\circ} \mathrm{C}$ durante 2 minutos, seguindo foi colocada na placa quente a $95,0 \pm 0,1{ }^{\circ} \mathrm{C}$ durante 2 minutos para pós-secagem do solvente. Para a revelação utilizou-se o revelador do SU-8 durante 2 minutos, agitando o béquer e movimentando a lâmina com a pinça, seguindo de enxague em álcool isopropílico durante $30 \mathrm{~s}$, agitando o béquer. $\mathrm{E}$ por fim a lâmina foi seca no spinner.

O SU-8 foi então litografado por feixe de elétrons, introduzindo em sua superfície estruturas periódicas na forma de cavidades hexagonais, como ilustra a figura 2.9. Os parâmetros $\beta, h$ e $2 R$, são as larguras das paredes, alturas das cavidades e diâmetro do círculo inscrito, respectivamente (veja a definição dos parâmetros $\beta, h$ e $2 R$ na figura 2.9). Para o parâmetro $2 \mathrm{R}$ foram tomados os valores de $12 \mu \mathrm{m}, 30 \mu \mathrm{m}, 80 \mu \mathrm{m}, 270 \mu \mathrm{m}$ e $560 \mu \mathrm{m}$ e o parâmetro h foi mantido constante e dado por $h=3 \mu \mathrm{m}$. Os valores para o parâmetro $\beta$ são dados na tabela 2.1 juntamente com os valores de $2 R$.

Outra amostra microestruturada em SU-8 foi planejada para a avaliação de cultura celular na presença de degraus na superfície. Amostra de SU-8 foi litografada utilizando a geometria apresentada na figura 2.9, mas com valores de $2 R=82 \mu \mathrm{m}, \beta=37 \mu \mathrm{m}$ e $h=3 \mu \mathrm{m}$. Dessa forma $40 \%$ da superfície da amostra fica em um nível abaixo do restante dela, sendo o desnível 
Tabela 2.1: Parâmetros de fabricação obtidos por medidas realizadas em MEV e AFM para a cavidades hexagonais nos diversos diâmetros. A variação das dimensões das amostras foram de $\pm 1 \mu \mathrm{m}$ para $2 R$ e de $\pm 0,5 \mu \mathrm{m}$ para $\beta$ e $h$.

\begin{tabular}{|c|c|c|c|}
\hline \multicolumn{3}{|c|}{ Parâmetros de fabricação das microcavidades. } \\
\hline \hline Cavidade & Diâmetro $(2 R)$ & $\beta$ & Altura $(h)$ \\
\hline HEX-12 & $12 \mu \mathrm{m}$ & $1,3 \mu \mathrm{m}$ & $3,0 \mu \mathrm{m}$ \\
\hline HEX-30 & $30 \mu \mathrm{m}$ & $2,0 \mu \mathrm{m}$ & $3,0 \mu \mathrm{m}$ \\
\hline HEX-80 & $80 \mu \mathrm{m}$ & $3,5 \mu \mathrm{m}$ & $3,0 \mu \mathrm{m}$ \\
\hline HEX-280 & $280 \mu \mathrm{m}$ & $6,5 \mu \mathrm{m}$ & $3,0 \mu \mathrm{m}$ \\
\hline HEX-560 & $560 \mu \mathrm{m}$ & $9,0 \mu \mathrm{m}$ & $3,0 \mu \mathrm{m}$ \\
\hline
\end{tabular}

de $3 \mu \mathrm{m}$ (que corresponde ao valor de $h$ ). A avaliação das culturas realizadas nos substratos descritos acima foi feita através da contagem do número de células vivas por unidade de área do substrato.

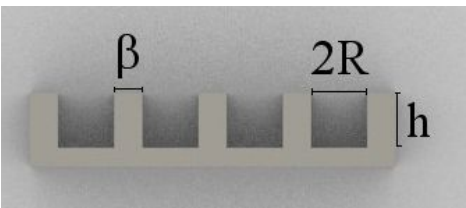

(a) Seção transversal.

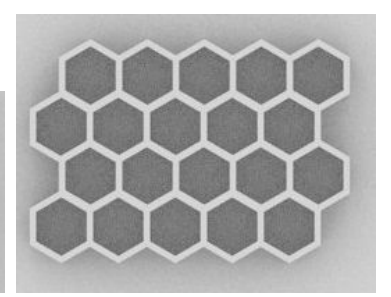

(b) Visão de topo.

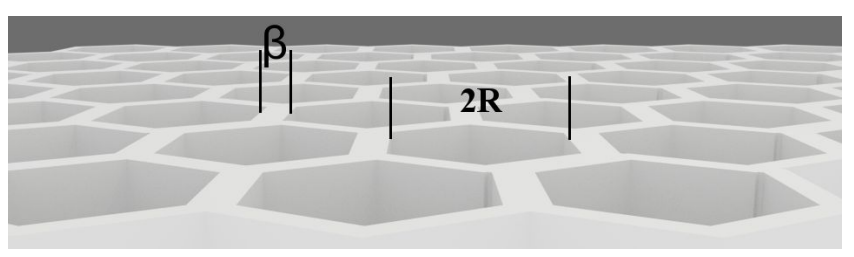

(c) Visão perspectiva.

Figura 2.9: Ilustração dos padrões que foram utilizados, (a) é mostrado a seção transversal do padrão. Em (b) é mostrado a visão de cima do padrão. Em (c) é mostrado uma visão em perspectiva do padrão.

\subsection{Materiais e métodos em cultura de células.}

O cultivo de células e a avaliação do desempenho de cultura celular sobre as superfícies modificadas foram realizados com a colaboração e supervisão da Prof ${ }^{\mathrm{a}}$. Dr ${ }^{\mathrm{a}}$. Daisy Maria Favero Salvadori e da Dra ${ }^{\mathrm{a}}$. Glenda Nicioli da Silva da Faculdade de Medicina da UNESP. Neste trabalho foi utilizada a linhagem CHO-K1 (Chinese Hamster Ovary cells) obtida do Banco de Células da Universidade Federal do Rio de Janeiro (UFRJ). 


\subsubsection{Descongelamento das células.}

Para descongelamento foi utilizado um criotubo de $1,0 \mathrm{~mL}$ (TPP) contendo $1 \times 10^{6}$ células $/ \mathrm{mL}$ de CHO-K1 mantidas em estado de criopreservação (DMSO a $10 \%$ ) em nitrogênio líquido. Uma vez que o criotubo contendo as células foi retirado do nitrogênio líquido, este foi rapidamente descongelado em temperatura ambiente por 2 minutos. O conteúdo foi ressuspenso em $10 \mathrm{~mL}$ de meio de cultivo em tubo para centrífuga de $15 \mathrm{~mL}$ (TPP). A centrifugação foi realizado durante 5 minutos a $1000 \mathrm{rpm}$ (180 g, onde g é a aceleração gravitacional). O sobrenadante foi desprezado e o precipitado de células foi, então, ressuspendido em $10 \mathrm{~mL}$ de meio de cultivo HAM-F10 (Cultilab, SP, Brasil) suplementado com $10 \%$ de Soro Fetal Bovino (Cultilab, SP, Brasil) e $1 \%$ penicilina/estreptomicina (Cultilab, SP, Brasil). O meio de cultivo suplementado com soro fetal bovino e antibióticos será ao longo do texto referido como meio completo [128].

\subsubsection{Cultivo de Células.}

Após serem descongeladas, as células $\mathrm{CHO}$ foram cultivadas em frascos de cultivo de $25 \mathrm{~cm}^{2}$ (TPP) e incubadas a $37 \pm 0,1{ }^{\circ} \mathrm{C}$ e em atmosfera úmida com injeção de $5 \%$ de $\mathrm{CO}_{2}$ até atingirem a confluência. A célula $\mathrm{CHO}$ apresenta ciclo celular de $24 \mathrm{~h}$, período em que uma célula necessita para duplicação do seu material genético. Mas, após o descongelamento nas primeiras $24 \mathrm{~h}$ troca-se apenas o meio de cultura.

\section{Subcultivo da linhagem de células (Passagem).}

Uma vez que as células contidas nos frascos de cultura atingiram a confluência, o meio de cultura já utilizado foi desprezado e a camada de células foi lavada com $10 \mathrm{~mL}$ de solução de Hanks $\left(0,4 \mathrm{~g} \mathrm{KCl}, 0,06 \mathrm{~g} \mathrm{KH}_{2} \mathrm{PO}_{4}, 0,04 \mathrm{~g} \mathrm{Na}_{2} \mathrm{HPO}_{4}, 0,35 \mathrm{~g} \mathrm{NaHCO}, 1 \mathrm{~g}\right.$ glucose and $8 \mathrm{~g}$ $\mathrm{NaCl}$ ). Após agitação cuidadosa, a solução de Hanks foi retirada e desprezada. Em seguida, colocou-se $4 \mathrm{~mL}$ de tripsina/EDTA (Cultilab, SP, Brasil) no frasco de $25 \mathrm{~cm}^{2}$ e esta permaneceu por 5 minutos na incubadora a $37^{\circ} \mathrm{C}$ em atmosfera úmida com $5 \%$ de $\mathrm{CO}_{2}$. No microscópio óptico invertido observou-se que as células $\mathrm{CHO}$ soltaram-se do frasco de cultura. Inibiu-se a tripsina/EDTA com $4 \mathrm{~mL}$ de meio de cultura completo. $\mathrm{O}$ volume final de suspensão de células foi homogeneizado com auxílio de pipeta Pasteur. Dividiu-se o volume final da suspensão de células em frascos de cultura novos contendo $10 \mathrm{~mL}$ de meio de cultura completo fresco. $\mathrm{O}$ subcultivo dos frascos de $25 \mathrm{~cm}^{2}$ foi realizado na proporção de $1: 2$ a cada $48 \mathrm{~h}$ [128]. 


\subsubsection{Contagem das células para semear as superfícies.}

Através de microscopia óptica é possível obter uma estimativa do quantitativo de células utilizando-se uma câmara de Neubauer, também conhecida como hemocitômetro ou câmara de contagem [97]. A câmara de Neubauer é uma lâmina espessa retangular e normalmente de vidro. A lâmina possui uma região de depressão (câmara) no centro de um volume conhecido, utilizada para fazer contagem de células por unidade de volume de uma suspensão. Esta câmara é gravada com uma grade de linhas perpendiculares (ver Figura 2.10). Esta grade é cuidadosamente elaborada, de modo que a área delimitada pelas linhas é conhecida, e a profundidade da câmara é também conhecida. Na grade de linhas existem 9 padrões quadrados em três diferentes tipos: A, B e C, de medidas conhecidas, que juntos formam um quadrado maior. A partir do número de células contidas em um quadrado é possível contar o número de células ou partículas de um volume específico de fluido, e, assim, calcular a concentração de células no líquido total. A área total compreendida pelas 9 regiões quadradas é de $9 \mathrm{~mm}^{2}$ sendo que cada região possui $1 \times 1 \mathrm{~mm}^{2}$ (ver Figura 2.10). Ao ser colocada uma lamínula de vidro (especial para ser usada na câmara de Neubauer) fechando a câmara de Neubauer a distância da lamínula até o rebaixo da câmara (profundidade) mede $0,1 \mathrm{~mm}$, o que permite se obter um volume de $0,1 \mathrm{~mm}^{3}$ projetado em cada quadrado [97].

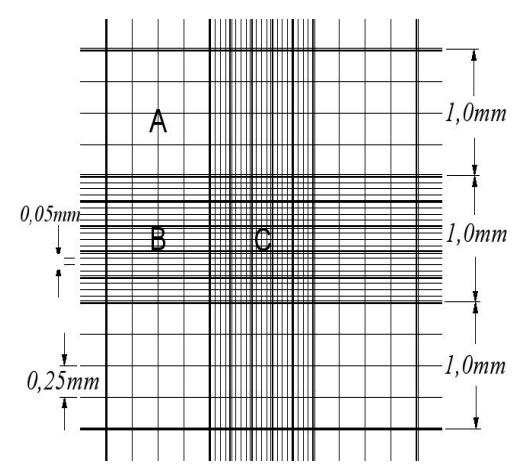

Figura 2.10: Figura ilustrativa do padrão gravado na câmara de Neubauer.

No procedimento de contagem as células foram lavadas com solução de Hanks e em seguida tripsinizadas. Nos processos de tripsinização foi utilizado uma solução balanceada com tripsina (2,5 g/L) sem íons cálcio e magnésio e com um agente quelante (EDTA), fornecido pela empresa Cultilab (SP, Brasil). Esta solução age permitindo o desprendimento de células aderentes dos frascos de cultivo, além de desagregar as células entre si através de sua ação proteolítica sobre proteínas intercelulares e, alterar a estabilidade das membranas ao quelar o íon cálcio. Uma vez que as células descolaram da parede do frasco de cultura estas foram passadas para tubos de Falcon de $15 \mathrm{~mL}$. Um volume de $10 \mu \mathrm{L}$ da suspensão de células foi coletado com auxílio 
de uma micropipeta e depositado na porção superior da câmara de Neubauer e outros $10 \mu \mathrm{L}$ da suspensão de células foram pipetados na porção inferior. No microscópio óptico foi efetuada a contagem.

Fizemos a contagem de células na região C (ver Figura 2.10) da câmara de Neubauer, mais precisamente nos 5 quadrados da diagonal dessa região; o valor foi divido por 5 , assim temos uma estimativa de células por quadrado. O valor final foi multiplicado por 25 que é o número total de quadrados contidos na região C. Assim obtivemos o valor quantitativo de células. Para obter o valor de células em suspensão, ou seja, o número total de células/mL, tivemos que dividir o valor obtido pelo volume da câmara na região C que é de $10^{-4} \mathrm{~mL}$ [97]. Assim temos que;

$$
\mathrm{n}^{\circ} \text { de células } \mathrm{mL}=\left(\frac{\mathrm{n}^{\circ} \text { total de células }}{\mathrm{n}^{\circ} \text { de quadrados contados }}\right) \times \text { fator de diluição } \times 10000
$$

onde, o fator de diluição adotado foi de 1 , esta expressão dará o número total de células/mL. Deste modo, através da expressão acima, pode-se planejar um número de células que se deseje semear, que será dado pela expressão abaixo:

$\mathrm{n}^{\circ}$ de células/mL da suspensão original $\times$ volume original

$$
=\text { volume final } \times \text { número de células desejadas } / \mathrm{mL}
$$

$\mathrm{ou}$

$$
\left(\frac{\mathrm{n}^{\circ} \text { de células } / \mathrm{mL} \text { da suspensão original }}{\text { número de células desejadas } / \mathrm{mL}}\right) \times \text { volume original }=\text { volume final }
$$

onde o volume final era dado em $\mu \mathrm{L}$ e continha o número de células que seria semeado nas superfícies de interesse.

\subsubsection{Criopreservação (Congelamento das células).}

Após confluência nos frascos de cultura de $25 \mathrm{~cm}^{2}$, para congelamento das células de CHO$\mathrm{K} 1$, desprezou-se o meio de cultura e lavou-se a camada de células com $5 \mathrm{~mL}$ de solução de Hanks. A solução de Hanks foi desprezada e as células foram tripsinizadas e permaneceram por 5 minutos em incubadora a $37^{\circ} \mathrm{C}$. A tripsina/EDTA foi então inibida com a mesma quantidade 
de meio de cultura completo. O volume final de suspensão de células foi homogeneizado com auxílio de pipeta Pasteur e transferido para tubo de Falcon (TPP) de $15 \mathrm{~mL}$. O tubo Falcon contendo suspensão de células foi centrifugado por 5 minutos a $1000 \mathrm{rpm}$ (180 g). Desprezouse o meio de cultura e as células totais que estavam no tubo de Falcon foram contadas com auxílio da câmara de Neubauer. O meio de congelamento foi preparado com meio completo e $10 \%$ de DMSO (autoclavado). A quantidade de células com meio completo e 10\% de DMSO foi ajustada de modo que ficasse $1 \mathrm{~mL}$ para cada $1 \times 10^{6}$ células. Posteriormente, $1 \mathrm{~mL}$ de meio de congelamento contendo as células foram distribuídas em criotubos com capacidade de 1,5 $\mathrm{mL}$ (TPP). Os criotubos foram mantidos a $-80{ }^{\circ} \mathrm{C}$ por $24 \mathrm{~h}$ e em seguida foram estocados em nitrogênio líquido $\left(-196^{\circ} \mathrm{C}\right)[97,100,128]$.

\subsection{Caracterização das superfícies lisas.}

\subsubsection{A análise de RBS (Rutherford Backscattering Spectrometry).}

A espectroscopia de retroespalhamento de Rutherford (RBS) é uma das muitas técnicas analíticas que fazem uso de aceleradores de partículas. Ela é uma importante ferramenta para análise de materiais. O RBS mede a energia de partículas carregadas (projétil), geralmente partículas alfa, que são retroespalhadas de uma amostra. A técnica de RBS fornece um poderoso método de se obter a distribuição em profundidade de elementos em ppm (partícula por milhão) contidos em superfície de filmes finos. Portanto, a técnica de RBS é vastamente utilizada na área de caracterização de materiais sendo uma técnica bem estabelecida e seus detalhes podem ser encontrados em diversas referências [129-131].

A técnica de RBS é largamente utilizada na análise de camadas depositadas próximas da superfície de um sólido. RBS pode ser usada para determinar a concentração atômica em função da profundidade quando elementos de maior número atômico $(Z)$ são depositados em um material composto de elementos leves, menor número atômico. A quantidade de energia perdida na colisão entre as partículas do feixe e os átomos do alvo depende apenas do número atômico $(Z)$ de cada elemento presente no material alvo. Desta forma, é possível identificar tais átomos. Geralmente, um feixe de íons de energia bem determinada, tipicamente da ordem de $2 \mathrm{MeV}$ incide na amostra a ser estudada, sendo espalhado por seus átomos. Os íons são retroespalhados em um ângulo tipicamente de $170^{\circ}$ e detectados. No nosso caso foi utilizado um feixe de partículas alfa com energia de $2,2 \mathrm{MeV}$.

Para o espalhamento devido à superfície da amostra, o único mecanismo de perda de energia é a transferência de momento para os átomos do alvo. A razão entre a energia do projétil depois 
da colisão $\left(E_{1}\right)$ e a energia do projétil antes da colisão $\left(E_{0}\right)$ define o fator cinemático. Para se obter uma expressão para o fator cinemático é assumido regime clássico com interações sendo elásticas. O fator cinemático $(K)$ será conforme as equações 2.4 e 2.5:

$$
K\left(\theta, M_{1}, M_{2}\right)=\frac{E_{1}}{E_{0}}
$$

ou

$$
K\left(\theta, M_{1}, M_{2}\right)=\left(\frac{\left(M_{2}^{2}-M_{1}^{2} \operatorname{sen}^{2}(\theta)\right)^{\frac{1}{2}}+M_{1} \cos (\theta)}{M_{1}+M_{2}}\right)
$$

onde $M_{1}$ e $M_{2}$ são as massas das partículas que se chocam e $\theta$ é o ângulo de espalhamento. A técnica de RBS foi utilizada para confirmar pelo método de espessura equivalente, a dose de $\mathrm{Ag}$ implantado nas amostras. Entretanto, como o alcance dos íons de Ag é de poucos nanômetros, não foi possível por RBS determinar experimentalmente a profundidade de implantação ou outros detalhes do perfil de implantação, uma vez que essa técnica tem resolução em profundidade de aproximadamente $20 \mathrm{~nm}$. Para caracterização por RBS, fizemos implantação sobre substratos de carbono vítreo.

\subsubsection{Caracterização por Ângulo de contato e Energia de Superfície.}

Quando uma gota de um líquido é colocada na superfície de um sólido, é formado o chamado ângulo de contato. 0 ângulo de contato é definido como sendo o ângulo subtendido entre a interface sólido/líquido e a tangente à interface líquido/ar, como se mostra esquematicamente na figura $2.11[132,133]$.
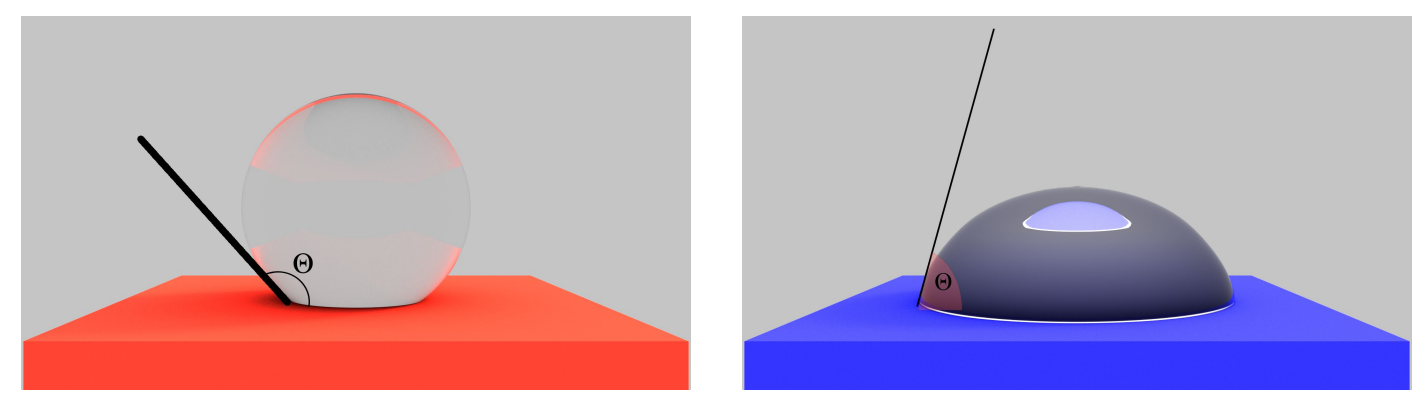

Figura 2.11: Considerando o líquido sonda como sendo água, a ilustração da esquerda mostra um exemplo de superfície hidrofóbica (ângulo de contato $>90^{\circ}$ ). A ilustração da direita apresenta um exemplo de gota em uma superfície hidrofílica (ângulo de contato $<90^{\circ}$ ). 
O ângulo de contato pode ser obtido através da equação de Young para uma superfície plana e homogênea. A equação de Young que relaciona o ângulo de contato e a energia de superfície é dada por [34, 134-139]:

$$
\gamma_{S}=\gamma_{S L}+\gamma_{L} \cdot \cos (\Theta)
$$

$\mathrm{Ou}$

$$
\gamma_{S L}=\gamma_{S}-\gamma_{L} \cdot \cos (\Theta)
$$

onde $\gamma_{S}$ é a energia de superfície do sólido, $\gamma_{S L}$ é a energia da interface existente entre sólidolíquido, $\gamma_{L}$ a energia superficial (ou tensão de superfície) do líquido sonda usado e $\Theta$ o ângulo de contato entre o sólido e o líquido sonda utilizado na medida. As grandezas $\gamma_{L}$ e $\Theta$ podem ser medidas.

Para avaliar a molhabilidade de superfícies, Fowkes [132, 140] forneceu um método para a análise desses experimentos propondo que a tensão de superfície $(\gamma)$ pode ser expressa como a soma de várias componentes:

$$
\gamma=\gamma^{d}+\gamma^{p}+\gamma^{i}+\gamma^{c}
$$

onde os índices se referem às contribuições devido às interações intermoleculares [141] de vários tipos: dispersão $\left(\gamma^{d}\right)$, dipolos $\left(\gamma^{p}\right)$, interações iônicas $\left(\gamma^{i}\right)$, contribuições covalentes $\left(\gamma^{c}\right)$. Na prática ele parou na polaridade, assumindo que para a molhabilidade a maioria da interações não envolvem contribuições químicas $\left(\gamma^{c}\right)$ e iônicas $\left(\gamma^{i}\right)$, conforme a equação 2.9. O primeiro termo representa as interações de dispersão de London $\left(\gamma^{d}\right)$ e a segundo representa as forças não dispersivas $\left(\gamma^{\text {nd }}\right)[132,141]$.

$$
\gamma=\gamma^{d}+\gamma^{n d}
$$

Seguindo as proposições de Fowkes, foram postuladas várias extensões para a equação 2.8 de modo a incluir outros tipos de interações de interface. Owens e Wendt estenderam a aproximação de Fowkes assumindo que a soma de todas as componentes da equação 2.8 , exceto $\gamma_{S}^{d}$, podem ser consideradas como interações do tipo polar $\gamma_{S}^{p}$. Consequentemente a equação 2.9 é modificada, obtendo-se a seguinte equação [23, 133, 140-143]: 


$$
\gamma=\gamma^{d}+\gamma^{p}
$$

onde $\gamma^{d}$ e $\gamma^{p}$ são as componentes dispersiva e polar, respectivamente.

Berthelot assumiu que o trabalho de adesão interfacial era uma média geométrica do trabalho de adesão do sólido $\left(W_{S S}\right)$ e do trabalho de coesão de um líquido $\left(W_{L L}\right)$, resultando na seguinte equação [140]:

$$
W_{S L}=\left(W_{S S} W_{L L}\right)^{0,5}
$$

Contudo, sabendo-se que [140] $W_{S S}=2 \gamma_{S}$ e $W_{L L}=2 \gamma_{L}$, onde $\gamma_{S}$ e $\gamma_{L}$ são as energias de superfície do sólido e do líquido, respectivamente. Ainda temos pela a equação de Dupre $[132,140]$ que o trabalho de adesão interfacial por ser dado por:

$$
W_{S L}=\gamma_{S}+\gamma_{L}-\gamma_{S L}
$$

Substituindo as equações 2.10 e 2.11 em 2.12 obtêm-se a equação [140]:

$$
\gamma_{S L} \cong \gamma_{S}+\gamma_{L}-2\left(\sqrt{\gamma_{S}^{d} \cdot \gamma_{L}^{d}}+\sqrt{\gamma_{S}^{p} \cdot \gamma_{L}^{p}}\right)
$$

A equação 2.13 é conhecida como média geométrica da energia de superfície. Para obtermos as componentes dispersiva $\gamma_{S}^{d}$ e polar $\gamma_{S}^{p}$ das superfícies de interesse neste trabalho, utilizamos o método de Fowkes extendido por Owens e Wendt (equação 2.13). As grandezas $\gamma_{L}, \gamma_{L}^{d}$ e $\gamma_{L}^{p}$ foram obtidas da literatura para 2 diferentes líquidos, um polar e outro apolar. Foram realizadas medidas de ângulo de contato na superfície sólida de interesse, utilizando esses dois líquidos sonda, obtendo $\Theta_{1}$ e $\Theta_{2}$. Utilizando as equações $2.7,2.10$ e 2.13, eliminamos $\gamma_{S L}$, obtendo

$$
1+\cos (\Theta)=2 \sqrt{\gamma_{S}^{d}}\left(\frac{\sqrt{\gamma_{L}^{d}}}{\gamma_{L}}\right)+2 \sqrt{\gamma_{S}^{p}}\left(\frac{\sqrt{\gamma_{L}^{p}}}{\gamma_{L}}\right)
$$

Os valores experimentais de $\Theta_{1}$ e $\Theta_{2}$, juntamente com os da literatura dos líquidos sonda, aplicados na equação 2.14 , fornecem um sistema de duas equações a duas incógnitas $\gamma_{S}^{d}$ e $\gamma_{S}^{p}$. Ou, alternativamente, um gráfico de $\left(\frac{1}{2} \frac{\gamma_{L}}{\sqrt{\gamma_{L}^{d}}}\right)(1+\cos (\Theta))$ em função de $\left(\frac{\sqrt{\gamma_{L}^{p}}}{\sqrt{\gamma_{L}^{d}}}\right)$ deverá produzir uma reta, de onde pode-se obter as componentes dispersiva $\gamma_{S}^{d}$ e não dispersiva $\gamma_{S}^{p}$ do sólido em estudo [23, 140, 143]. Esta equação foi usada para cálculo das energias livre das superfícies modificadas por plasma. 
Realizamos as medidas de ângulo de contato no sistema automatizado Contact angle goniometer CAM200 (processo FAPESP número 06/07306-4) que permite posicionamento controlado de uma gota, de um volume definido, sobre a superfície em estudo. A imagem da gota sobre a superfície pode ser gravada a 1 quadro/segundo ou 62 quadros/segundo. Assim, têm-se duas formas de registro da imagem da gota. A primeira delas na situação de equilíbrio da gota sobre a superfície. A segunda forma consiste em inclinar a superfície (juntamente com a câmera de registro de imagem), até que a gota começe a se deslocar, com registro periódico de imagens. No instante de iminência de movimentos da gota, o ângulo de avanço e o ângulo de recesso podem ser obtidos (ver Figura 2.12). Utilizando as imagens registradas, o software determina o ângulo de contato ajustando uma expressão matemática ao formato da gota (Young-Laplace) e calculando a inclinação da tangente à gota na interface líquido-sólido- vapor (Figura 2.12).

Quando se aplica o método de Fowkes, é necessário utilizar dois líquidos sonda, água deionizada (18,2 M $\Omega \mathrm{cm}$, Millipore) e etileno glicol (Merck) foram utilizados no nosso caso. A água é considerada como líquido sonda que possui a componente polar dominante $\left(\gamma_{L}^{d}=21,8 \mathrm{mN} / \mathrm{m}\right.$ e $\gamma_{L}^{p}=51,0 \mathrm{mN} / \mathrm{m}$ ) enquanto que o etileno glicol foi utilizado como líquido sonda dispersivo $\left(\gamma_{L}^{d}=32,8 \mathrm{mN} / \mathrm{m}\right.$ e $\left.\gamma_{L}^{p}=16,0 \mathrm{mN} / \mathrm{m}\right)$.

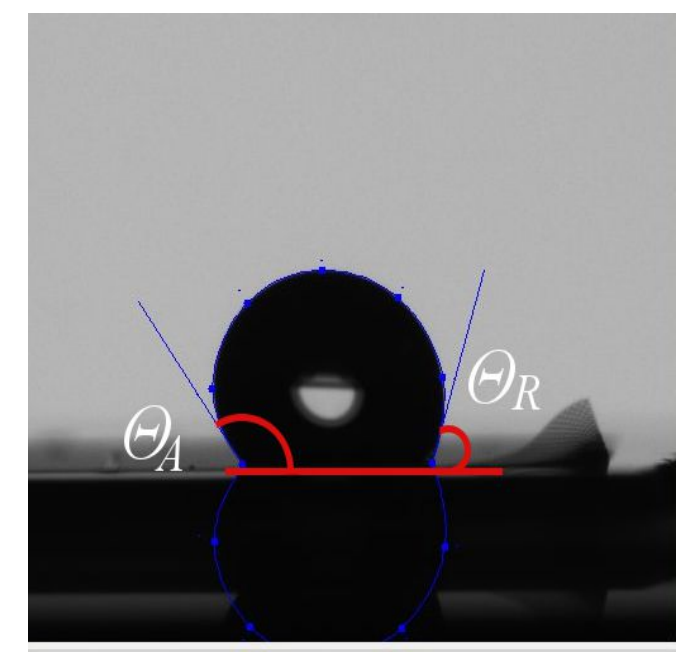

Figura 2.12: Ajuste do ângulo de contato calculado pelo software de controle do equipamento CAM200. $\Theta_{A}$ e $\Theta_{R}$ são os ângulos de avanço e recesso, respectivamente.

\subsubsection{Microscopia de Força Atômica.}

Em todos os dias de nossas vidas podemos obter informações acerca da topografia e outras propriedades dos objetos tocando suas superfícies com nossos dedos. Além de perceber a rugosidade da superfície podemos sentir também propriedades tal como elasticidade, atrito, 
dureza, temperatura e granularidade. Estas propriedades podem ser analisadas de forma similar (respeitando-se os limites da analogia) em uma escala milhões de vezes menor, por meio de Scanning Probe Microscopy (SPM) [144, 145]. O SPM é uma família de técnicas de microscopia, projetadas para analisar diversos tipos de interações físicas e químicas da sonda com a superfície das amostras. Um SPM oferece a possibilidade de operar em muitos modos diferentes, o que torna esta técnica extremamente versátil, pois pode ser adaptada a muitas classes de materiais, desde materiais de estado sólido até moléculas de sistemas biológicos [146]. O coração do AFM (Atomic Force Microcopy), uma dessas técnicas, é sua sonda, uma ponta ligada a extremidade de uma haste flexível (cantiléver), que interage com a superfície da amostra enquanto uma área é varrida sob a ponta. As forças de interação entre a ponta e a amostra faz com que haja uma flexão/deflexão do cantiléver quando a amostra é varrida sob a ponta (ver Figura 2.13). Os pequenos movimentos do cantiléver são detectados por um sistema em que um feixe de laser fixo incide no cantiléver e é refletido num fotodetector (ver Figura 2.13). A interação entre a ponta e a superfície da amostra é registrada ponto a ponto. Com base nesse registro é possível construir uma imagem $(x, y, z)$ da superfície da amostra, onde, $x$ e $y$ são as coordenadas da superfície da amostra e $z$ a interação medida entre a ponta e a amostra, como a deflexão do cantiléver (ver Figura 2.13) [144-146].

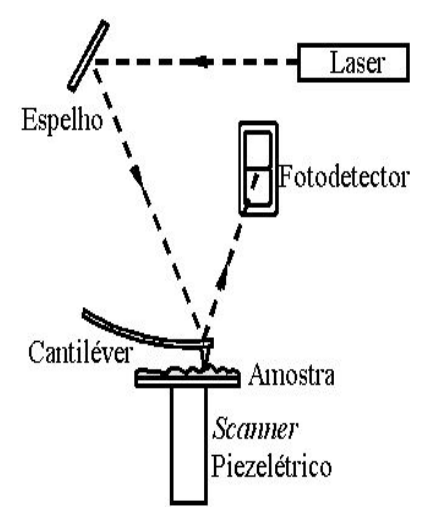

Figura 2.13: Esquema ilustrativo do funcionamento do AFM.

\section{Descrição dos Modos AFM.}

O AFM se subdivide em três modos:

AFM de contato

AFM de contato intermitente

AFM de não-contato 
Mais especificamente foram utilizados neste trabalho os dois primeiros modos.

\section{Descrição do Modo AFM de Contato.}

Neste modo de operação, a sonda consiste em uma ponta presa a um cantiléver, que se mantém em contato com a superfície da amostra durante toda a varredura [147], como indica a Figura 2.14. Quando a ponta varre a superfície da amostra, passa por pontos de diferentes alturas, gerando variações na deflexão do cantiléver. Como já mencionado, estas deflexões são medidas através de um feixe de laser refletido na ponta do cantiléver, chegando até um fotodetector. Através de um feedback com um computador, a deflexão do cantiléver é mantida constante durante a varredura, movendo a amostra verticalmente, a cada ponto. A posição vertical da amostra, juntamente com a posição $(x, y)$ correspondente, é armazenada em computador formando, ao final da varredura, a imagem topográfica da superfície da amostra.

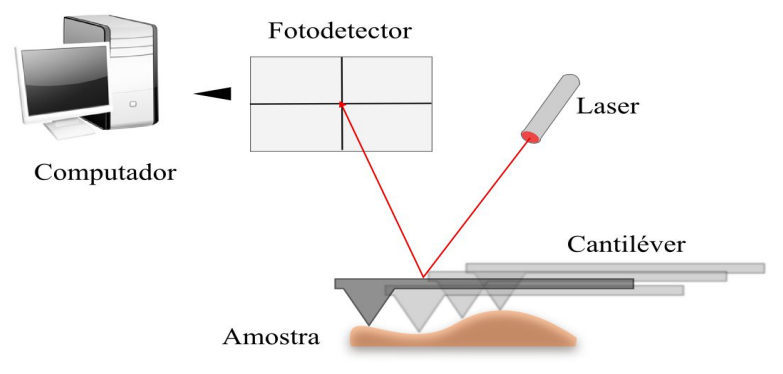

Figura 2.14: Esquema apresentando o princípio básico de funcionamento de um AFM de contato.

Note que, mantendo a deflexão do cantiléver constante, a força entre ponta e amostra também se mantém constante e dada por: $F=-k \cdot x$ (lei de Hooke), onde $F$ é o módulo da força que a ponta exerce sobre a amostra, $k$ é a constante de mola associada à deformação do cantiléver, e $x$ é a deflexão do cantiléver. Sendo $k$ entre 0,01 e 1,0 N/m a força resultante está entre $\mathrm{nN}$ e $\mu \mathrm{N}$.

\section{Descrição do AFM de Contato Intermitente.}

Nesse modo de operação a sonda consiste em uma ponta presa a um cantiléver oscilante que, durante a varredura, toca a superfície da amostra no ponto de máxima amplitude de oscilação. O cantiléver oscila em sua frequência de ressonância, ou próximo dela, com uma amplitude típica entre $20 \mathrm{~nm}$ e $100 \mathrm{~nm}$. Durante a varredura, a ponta oscilante passa por diferentes alturas da amostra, gerando variações na amplitude de oscilação da ponta. A amplitude de oscilação 
da ponta é definida, na verdade, pelo seu RMS (root mean square), que é obtido através do sinal gerado no fotodetector pelo feixe de laser refletido no cantiléver. Através de um feedback com um computador, o RMS da amplitude de oscilação da ponta é mantido constante durante a varredura, movendo a amostra verticalmente, a cada ponto. Assim, a posição vertical da amostra, juntamente com a posição $(x, y)$ correspondente, é armazenada em computador formando, ao final da varredura, a imagem topográfica da superfície da amostra. Note que neste caso, o contato entre ponta e amostra é bastante delicado, sendo um modo de operação indicado para amostras frágeis [147].

A técnica de AFM foi utilizada para determinar a altura das paredes das microestruturas fabricadas em SU-8. O AFM foi utilizado também para comparar diferenças morfológicas entre as superfícies de SU-8/Ag e SU-8.

\subsection{Caracterização da superfícies microfabricadas.}

\subsection{1 Ângulo de Contato.}

A molhabilidade de uma superfície depende do equilíbrio termodinâmico entre um sistema de três interfaces: sólido, líquido e vapor. Assim, para se estudar a molhabilidade de uma superfície coloca-se uma gota sobre a mesma e determina-se o ângulo de contato. O ângulo de contato representa uma medida quantitativa do processo de molhabilidade. Este é definido como o ângulo entre um plano tangente a uma gota do líquido e um plano contendo a superfície onde o líquido se encontra depositado, conforme esquematizado na figura 2.15 .
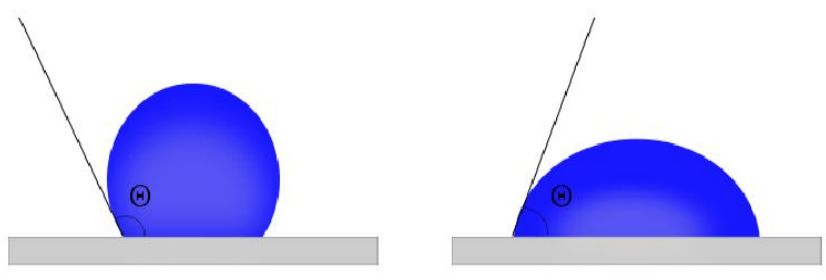

Figura 2.15: Figura do ponto de intersecção entre sólido, líquido e vapor ilustrando a formação do ângulo de contato

Diz-se que um líquido molha um substrato quando o ângulo de contato formado entre o líquido e o sólido é menor que $90^{\circ}$. Quando água é utilizada como líquido sonda tem se que 
para $\Theta>90^{\circ}$ a superfície é dita ser hidrofóbica e para valores de $\Theta<90^{\circ}$ a superfície é dita ser hidrofóbica (ver Figura 2.15). O líquido sonda mais adequado para o estudo, levando em consideração a molhabilidade e a não polaridade da superfície do substrato, é a água deionizada. A água utilizada neste trabalho foi obtida em um deionizador Millipore $(18,2 \mathrm{M} \Omega \mathrm{cm}$, Millipore).

\subsubsection{Microscopia Eletrônica de Varredura (MEV).}

Utilizou-se um Microscópio Eletrônico de Varredura Jeol 6460LV do Laboratório de Filmes Finos para caracterização topográfica de superfícies. Brevemente descrevendo, dentro de uma coluna em alto vácuo mostrada na Figura 2.16a, os elétrons são gerados a partir de um catodo termiônico de tungstênio e acelerados em direção ao sistema óptico-eletrônico, por uma diferença de potencial entre catodo e ânodo que pode variar entre $0,3 \mathrm{kV}$ e $30 \mathrm{kV}$. O feixe gerado pelo canhão de elétrons passa por lentes condensadoras que colimam o feixe e reduzem seu diâmetro. Bobinas de deslocamento do feixe de elétrons realizam a varredura no plano $(x, y)$ e bobinas específicas corrigem o astigmatismo. A lente objetiva focaliza o feixe sobre a superfície da amostra.

Dependendo do material e da energia do feixe de elétrons, quando focalizado em uma pequena área da amostra, o feixe irá interagir numa profundidade de um a poucos micrômetros, criando o chamado volume de interação, como apresentado na figura 2.16b. Nessa interação uma série de sinais são gerados e podem ser utilizados para caracterizar propriedades da amostra, tais como; topografia, composição química e informações cristalográficas. Os elétrons retro espalhados e elétrons secundários são responsáveis pelos sinais que serão convertidos em imagem. Os elétrons do feixe que sofrem colisão elástica com os átomos da amostra, sem alteração significativa da sua energia, são os elétrons retroespalhados. Interações inelásticas do feixe com a estrutura de banda do material geram uma série de sinais, sendo um deles o de elétrons secundários. 


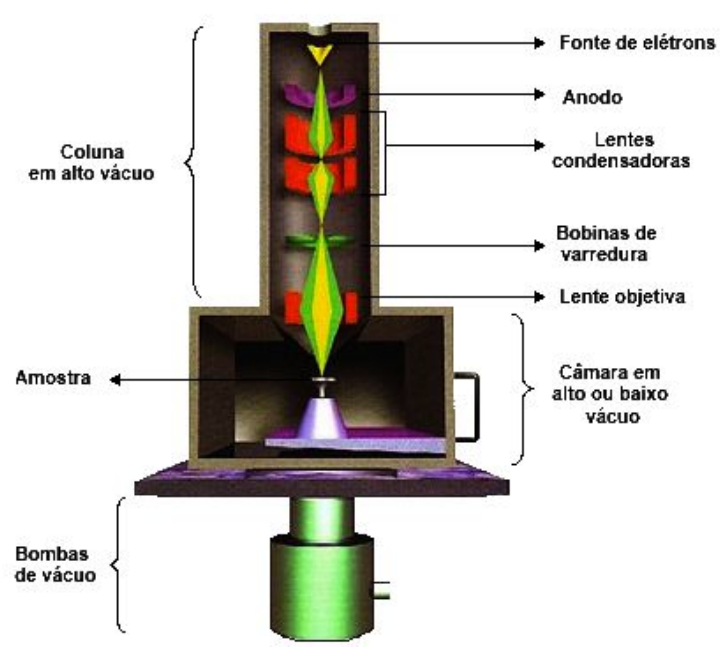

(a) Coluna óptico-eletrônica.

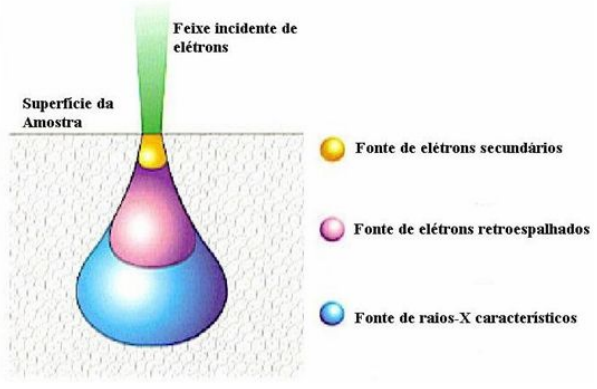

(b) Volume de interação.

Figura 2.16: (a) temos a coluna óptico-eletrônica de um Microcópio Eletrônico de Varredura. (b) Volume de interação na amostra atingida pelo feixe de elétrons.

Para formação da imagem, o fluxo de informação do microscópio para o computador de controle consiste na localização dos pontos da varredura no plano $(x, y)$ com o conjunto de intensidades correspondentes, originadas pelo detector de elétrons retroespalhados ou pelo detector de elétrons secundários.

\subsection{Caracterização do desempenho da cultura de células nas diversas superfícies.}

\subsubsection{Teste de viabilidade celular.}

O crescimento celular foi realizado sobre as superfícies modificadas e o número de células vivas por unidade área foi quantificado em micrografia óptica para cada substrato. A viabilidade celular das células $\mathrm{CHO}$ após o período de 24 horas de cultura foi realizada através do método de exclusão do trypan blue. Resumidamente, uma solução recém preparada de $500 \mu \mathrm{L}$ de trypan blue $(0,05 \%)$ em água destilada foi misturada ao mesmo volume de meio de cultura fresco. Cerca de 20 a $30 \mu \mathrm{L}$ desta solução foi colocado em cada substrato de modo a cobrir completamente a superfície que continham células aderidas. Aguardou-se um intervalo de tempo de 3 minutos, para que fossem capturadas imagens de microscopia óptica em cinco regiões diferentes de cada superfície. As células mortas, seja por apoptose ou necrose, ficavam marcadas em azul. 


\subsubsection{Fator de Forma.}

Inicialmente foram realizadas culturas celulares em vidro, SU-8, PDMS e DLC sem tratamento prévio e sem a introdução de microestruturas, isto é, foram utilizadas superfícies planas e sem tratamento. A avaliação dessas culturas foi feita através do cálculo dos fatores de forma. Definiremos aqui um parâmetro importante para a avaliação de uma superfície quanto ao crescimento celular, onde o critério leva em conta a forma (morfologia) das células. É conhecido [148] que as células que apresentem geometria esférica mantêm baixa adesão ao substrato e a alta ocorrência dessa geometria significa que o substrato não é favorável para a cultura. Assim, o fator de forma $F_{f}$ é definido de acordo com a expressão dada pela equação [148].

$$
F_{f}=\frac{4 \pi \times \text { Área }}{(\text { Perímetro })^{2}}
$$

onde a área e o perímetro das células podem ser medidos em uma imagem de microscopia óptica através de softwares como Image pro/ ImageJ. Dada a definição do fator de forma, seu valor poderá variar entre 1 (para um círculo perfeito) até 0 (uma linha reta onde a área seria nula) como é ilustrado na figura 2.17.
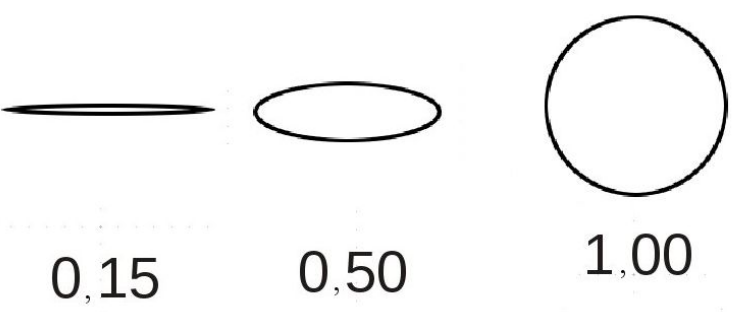

1,00

Figura 2.17: Ilustração da variação do fator de forma $F_{f}$ com a variação da geometria.

Assim, para células mais elongadas temos um baixo valor de fator de forma enquanto que para as células mais circulares, representando baixa adesão, temos valores que se aproximam da unidade. Dessa forma, podemos avaliar numericamente a adesão das células ao substrato e a consequente adequação deste para a cultura celular.

\subsubsection{Microscopia Óptica de Fluorescência.}

Fotoluminescência é nome que se dá ao efeito de uma amostra absorver e re-irradiar fótons (luz). Se a luz é interrompida, mas a re-emissão persiste por alguns segundos, o efeito é chamado de fosforescência. A fluorescência ocorre quando a re-emissão ocorre apenas durante 
a absorção da radiação excitante. O intervalo de tempo entre os processos de absorção e re-emissão é da ordem de um milionésimo de segundo. Quando uma molécula fluorescente absorve um fóton de comprimento de onda adequado, um elétron é excitado para um estado de energia mais alto e quase imediatamente volta ao seu estado inicial. Nesse processo, o átomo/molécula pode liberar a energia absorvida como um fóton fluorescente. Como um pouco da energia absorvida é perdida no processo, o fóton fluorescente emitido possui uma menor frequência de vibração, ou seja, um comprimento de onda maior do que do fóton inicialmente absorvido. Esse efeito forma a base da microscopia de fluorescência.

Através da Microscopia Óptica de Fluorescência é possível visualizar moléculas específicas que fluorescem na presença de radiação excitante. A técnica pode ser usada para determinar a quantidade, distribuição e dinâmica de macromoléculas específicas em células, possibilitando o estudo de diversos mecanismos celulares [97].

Geralmente, as amostras não são auto-fluorescentes e o uso de corantes chamados fluoróforos (ou fluorocromos) é necessário para torná-las fluorescentes. Os fluoróforos são moléculas que absorvem fótons com energia de determinado espectro de excitação e re-emitem fótons com energia em determinado espectro de emissão (ou de fluorescência). Os espectros de excitação e de emissão possuem um pico de intensidade. A diferença em nanômetros entre os picos do espectro de excitação e do espectro de emissão é chamado de desvio de Stokes. Quanto maior o desvio de Stokes, mais vantajoso é o corante, pois as bandas de excitação e fluorescência são mais fáceis de serem isoladas usando filtros de interferência. Para o fluoróforo DAPI, por exemplo, o comprimento de onda de absorção referente ao pico de intensidade é de $345 \mathrm{~nm}$, enquanto que o pico de emissão fluorescente ocorre para comprimento de onda de $460 \mathrm{~nm}$, o que dá uma diferença de $115 \mathrm{~nm}$ (desvio de Stokes) que é bem interessante para a técnica. Outra característica importante de um fluoróforo é a eficiência quântica de emissão de fluorescência, que é a razão entre o número de fótons fluorescentes emitidos e o número de fótons absorvidos. O coeficiente de extinção molar descreve a capacidade do corante em absorver um fóton. Outras características relevantes dos fluoróforos são sua resistência à fotodegradação, sua solubilidade em meio aquoso e sua estabilidade química. Mais de um fluoróforo pode ser utilizado ao mesmo tempo em uma amostra, registrando diferentes estruturas ou processos da amostra. Existem algumas substâncias naturalmente fluorescentes em produtos comuns, tais como extrato de espinafre (vermelho), extrato de cenoura (amarelo), leite em pó (azul) e margarina (azul).

O microscópio de fluorescência possui uma série de modificações importantes para se obter imagens brilhantes e bem definidas. Eles possuem filtros especiais e um método específico de 
iluminação para a produção de imagens. Para imagem eficiente de alto contraste, a iluminação e a objetiva são posicionadas do mesmo lado da amostra. Assim, as lentes objetivas funcionam tanto como lentes condensadoras, incidindo a radiação excitante sobre a amostra, quanto coletando a luz fluorescente emitida pela amostra. Os filtros são projetados para isolar dois conjuntos distintos de comprimentos de onda, os de excitação e os de fluorescência (ou emissão). A banda de comprimentos de onda de excitação (que são curtos) vinda do iluminador e filtros é direcionada para a amostra, enquanto que a banda de comprimentos de onda longos de fluorescência emitida pela amostra forma a sua imagem. São usadas objetivas de alta abertura numérica para maximizar a coleta de luz e fornecer a melhor resolução e contraste possíveis.

Uma fonte de luz brilhante como uma lâmpada de arco de xênon ou de mercúrio, chamada de epi-iluminador, é necessária já que uma banda fina de comprimentos de onda curtos é usada para excitar os fluoróforos. Lâmpadas de $100 \mathrm{~W}$ de mercúrio ou $75 \mathrm{~W}$ de xênon são geralmente usadas. Ambas as lâmpadas fornecem a banda entre $400-700 \mathrm{~nm}$, mas a lâmpada de mercúrio, conhecidamente, possui linhas de emissão bem definidas em 366 (UV), 405, 436, 546 e 578 nm. Essas linhas são úteis para excitar certos fluoróforos, como DAPI, por exemplo. Em $546 \mathrm{~nm}$, essas lâmpadas são de 10 a $100 X$ mais brilhantes do que a lâmpada de $100 \mathrm{~W}$ halogênea, comumente utilizada em microscopia de campo claro, e essa vantagem é necessária para a Microscopia de Fluorescência. Conjuntos de filtros fluorescentes, cada um contendo três filtros essenciais (filtro de excitação, espelho dicroico e filtro de barreira, para emissão) são montados na forma de um cubo no caminho óptico entre o epi-iluminador e a objetiva (veja figura 2.18). O filtro de excitação seletivamente transmite uma banda de comprimentos de onda curtos para excitar o fluoróforo na amostra. O espelho dicroico reflete a luz de comprimento de onda curto em direção às lentes objetivas e amostra, mas transmite a luz fluorescente de comprimento de onda longo em direção ao detector. O filtro de barreira transmite a banda de comprimentos de onda fluorescentes, mas bloqueia qualquer comprimento de onda curto de excitação residual. Os comprimentos de onda fluorescentes formam então a imagem no olho ou na câmera.

Para realizar imagens de fluorescência deve-se saber selecionar corretamente o(s) fluoróforo(s), os filtros e iluminação adequada, além de avaliar corretamente a qualidade dos sinais de fluorescência. Deve-se também tentar evitar a fotodegradação, interrompendo a iluminação para a amostra nos momentos em que ela não está sendo observada.

As amostras/superfícies ainda com as células aderidas foram enxaguadas 3 vezes com PBS $1 \mathrm{M}$ a $37^{\circ} \mathrm{C}$ e as células foram fixadas a temperatura ambiente em uma solução de paraformaldeído a $4 \%$ por 15 minutos. Em seguida, enxaguadas 3 vezes em solução 0,2\% de Triton X100 em PBS por 5 minutos cada. Aplicou-se o então Prolong Gold Dapi( Life technologies) 


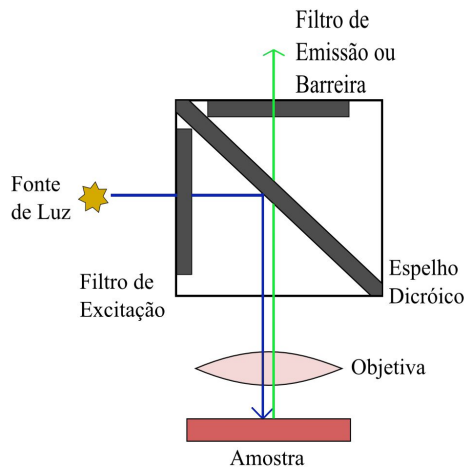

Figura 2.18: Ilustração do cubo de filtros utilizado na microscopia de fluorescência.

seguido de incubação da amostras a temperatura ambiente em local escuro por $24 \mathrm{~h}$. Após o periodo de incubação em ambiente escuro fizemos microscopia de fluorescência. Foram capturadas 10 imagens no Microscópio Óptico BX 51 da Olympus com módulo de fluorescência(URFL-T). Para captura utilizamos objetiva de $20 X$ e cambiador 2, ou seja, uma imagem de $437 \times 328 \mu \mathrm{m}^{2}$.

\subsubsection{Análise da função de correlação em imagem de microscopia óptica.}

A função de correlação pode ser usada para estudar partículas em suspensão coloidal [149151], tamanhos de agregados e a dinâmica de agregamento [152]. Em microbiologia é possível estudar dinâmica de agregamento [153] bem como a dinâmica de dissociação de agregados de micro-organismos [154]. Portanto, a função de correlação é uma importante ferramenta que fornece informação sobre organização dos elementos por ela analisada.

A função de correlação entre duas funções $f(x, y)$ e $h(x, y)$ pode ser representada pela expressão dada pela equação 2.16 , como sendo:

$$
\operatorname{Corr}(x, y)=(f \otimes h)(a, b)=\iint f^{*}(x, y) h(x+a, y+b) d x d y
$$

onde $f^{*}(x, y)$ é o complexo conjugado de $f(x, y)$. A função de correlação fornece informação sobre similaridades entre as diversas partes das funções. De forma geral a função de correlação dá um significado de "combinar"as duas funções e comparar propriedades presentes nas mesmas. A função de autocorrelação pode ser definida como é apresentado na equação 2.17 [155, 156]:

$$
\operatorname{Corr}(x, y)=(f \otimes f)(a, b)=\iint f^{*}(x, y) f(x+a, y+b) d x d y
$$


Podemos ter uma grandeza $X$ proveniente de um processo estocástico, assumindo valores para uma função, $\operatorname{Corr}(X)$. A correlação entre os elementos da função $\operatorname{Cor}(X)$, ou seja, $\operatorname{Corr}\left(X_{i}, X_{j}\right)$ é chamado de autocorrelação de $X$. O conceito de autocorrelação é uma ferramenta extremamente importante em análises de imagens, pois fornece quanto cada ponto está relacionado com suas vizinhanças [155].

Estritamente falando, quando se trata de análise de imagens, a função de correlação $\operatorname{Corr}(\vec{r})$ está relacionada com a probabilidade de encontrar o centro de uma partícula a uma dada distância do centro de uma outra partícula. A função de correlação para imagem pode ser dada conforme a equação 2.18:

$$
\operatorname{Corr}(\vec{r})=\langle\rho(\vec{r}) \times \rho(\vec{r}-\vec{R})\rangle / \rho^{2}
$$

onde, $\rho$ seria a densidade de partículas em uma determinada coordenada $\vec{r}$.

Para pequenas distâncias, a função de correlação está relacionada em como as partículas estão acondicionadas (organizadas) em conjunto [157]. A função de correlação pode ser calculada pela Eq. 2.17 e passando-a para o espaço de frequência através da Fast Fourier Transform $(F F T)$, obtemos a equação $2.19[155,158]$ :

$$
\operatorname{Corr}(\vec{r})=F F T^{-1}\left(\mid\left. F F T(\text { Imagem })\right|^{2}\right) / \rho^{2} N(\vec{r})
$$

Onde $F F T^{-1}$ é a transformada inversa de Fourier e $\rho^{2} N$ é um fator de normalização que leva em conta uma região parcial da imagem completa. Para fazer essas operações diretamente na imagem podemos usar as ferramentas de processamento de imagem do software Matlab 2013a(8.1.0.604) [159-161]. Esta tarefa pode ser realizada também no software Mathematica 9.0.1.0 [155, 158, 162].

A morfologia dos núcleos das células foram observadas usando um microscópio de epifluorescência (Olympus BX 51, com U-RFL-T fluorescência módulo) equipado com uma CCD (QColor 5) no comprimento de onda de excitação $350 \mathrm{~nm}$. Os núcleos são considerados como tendo o fenótipo de morfologia intacta quando apresentam incandescência brilhante e homogênea. Núcleos apoptóticos pode ser identificado através do recolhimento de cromatina condensada na periferia da membrana nuclear ou uma morfologia fragmentada total de corpos nucleares [163].

Um exemplo de imagem obtida por microscopia de fluorescência é apresentado na figura 2.19a. Essa imagem foi processada para separação dos Canais RGB (Red, Green, Blue). Uma vez que os canais foram separados trabalhamos apenas com a informação contida no canal azul, conforme é apresentado na figura $2.19 \mathrm{~b}$, obtendo imagem em tons de cinza. Para realizar esta 
tarefa utilizou-se o software ImageJ [164-166] ou o software Fiji [167]. Para tornar a imagem binária, primeiro tivemos que mudar a cor das estruturas hexagonais (litografia) para a cor do fundo e prosseguir com a binarização. Dessa forma apenas os núcleos estão em tons de cinza. Na figura 2.19c tem-se a imagem final, onde os núcleos estão na cor branca e são associados ao valor 1 e o fundo, na cor preta, é associado ao valor 0 (zero). Dessa forma, a imagem está no formato final para ser analisada pela função de correlação. Essas imagens (figura 2.19) possuem $437 \times 328 \mu \mathrm{m}^{2}$ sendo o tamalho de pixel $0,17 \mu \mathrm{m}$.

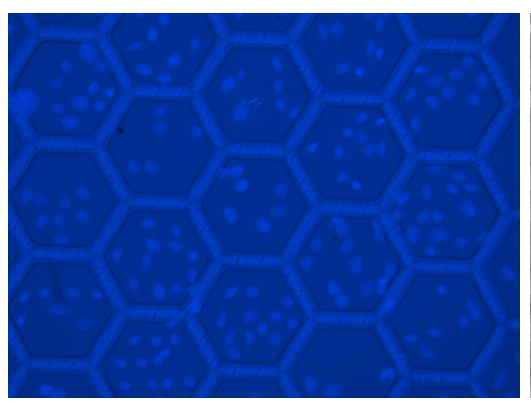

(a) Imagem original.

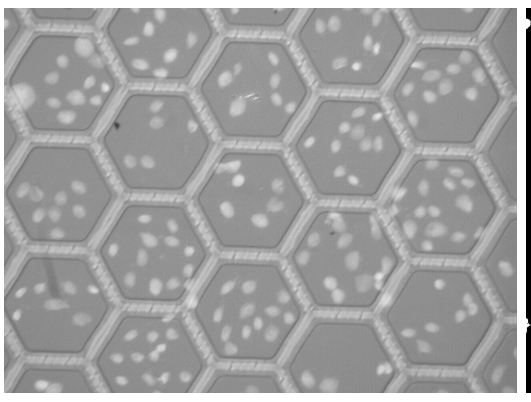

(b) Imagem do canal azul.

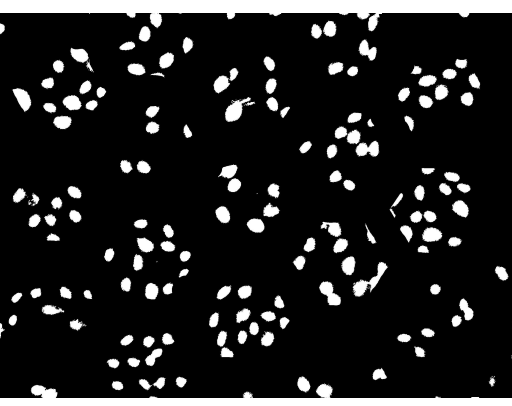

(c) Imagem binarizada.

Figura 2.19: Na figura (a) temos uma imagem da superfície da amostra contendo estruturas Hexagonais litografados com células semeadas e marcadas com DAPI. Na figura (b) temos uma imagem contendo apenas a informação do canal azul da micrografia. Na figura (c) temos a imagem binarizada do canal azul.

A partir da figura 2.19c, foi realizado o cálculo da função de correlação tal como proposto pela equação 2.19. Obtêm-se assim, a função de correlação para cada superfície litografada e SU-8 liso para 3 imagens para cada amostra. Fizemos ajustes matemáticos nas funções de correlação obtidas de onde obtivemos informações sobre organização das células nestas microestruturas. Os ajustes foram feito para a função de correlação segundo método utilizado por Wormington [168].

$$
\operatorname{Corr}(r)=1+A \cdot \exp \left(-r / d_{c}\right) \cos \left(\pi r / r_{c}\right)
$$

onde, A é uma constante $d_{c}$ é a distância entre aglomerados e $r_{c}$ é o raio dos aglomerados, tal como realizado por Gompper e colaboradores [169]. 


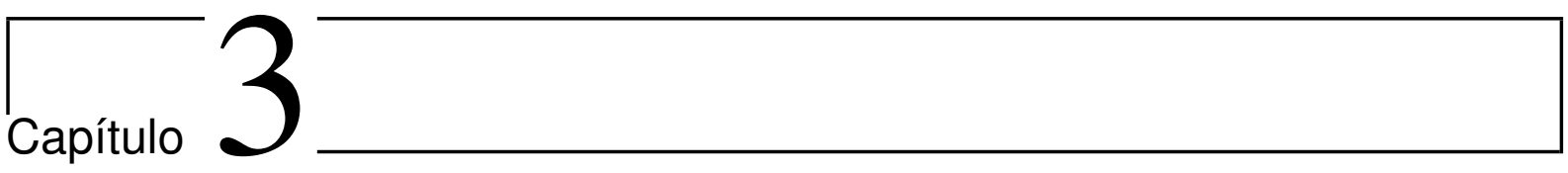

\section{RESULTADOS EXPERIMENTAIS E DISCUSSÃO.}

\subsection{Resultados para superfícies lisas.}

Inicialmente foram realizadas culturas celulares em vidro, SU-8, PDMS e DLC originalmente depositado e sem a introdução de microestruturas, isto é, foram utilizadas superfícies lisas (planas, rugosidade $R M S<2 \mathrm{~nm}$ ) e sem tratamento. A avaliação dessas culturas foi feita através do cálculo dos fatores de forma.

Para a realização destes experimentos, foram testadas diversas quantidades de células a serem cultivadas, sendo que o melhor valor encontrado a partir de experimentos anteriores foi de $6 \times 10^{4}$ células por poço quando estas superfícies foram analisadas por microscopia óptica (MO). Todas as amostras/superfícies permaneceram imersas em álcool $70 \%$ durante o tempo de 40 minutos imediatamente antes da semeadura das células CHO. Foram então semeadas células em placas de 12 poços com os substratos contendo cada uma das 4 superfícies mencionadas, em triplicata, contendo os substratos com superfícies modificadas a serem testados. Após 24 horas de incubação, a $37{ }^{\circ} \mathrm{C}$ e em atmosfera úmida com injeção de $5 \%$ de $\mathrm{CO}_{2}$ as células em cada uma das superfícies foram analisadas por microscopia óptica para avaliação da viabilidade celular. Os experimentos foram sempre realizados com as células em crescimento exponencial e sempre com as culturas entre a $3^{a}$ e a $5^{a}$ passagem, ou seja, as células encontravam-se entre o $3^{\circ}$ e o $7^{\circ}$ dia de cultura. A $3^{a}, 4^{a}$ e $5^{a}$ passagens serão denominadas como experimentos $\mathrm{A}$, B e $\mathrm{C}$, respectivamente. 


\subsubsection{Resultados para o fator de forma.}

Foram adquiridas 5 imagens em MO da cultura celular de cada amostra em triplicata, totalizando 15 imagens para cada uma das 4 superfícies em estudo, sendo estas, vidro, SU-8, PDMS e DLC sem tratamento prévio e sem a introdução de microestruturas. De cada imagem foram medidos perímetro e área de 30 células e, utilizando a equação 2.15 , obteve-se 450 valores do fator de forma $\left(F_{f}\right)$ para cada superfície em análise. Dois exemplos de imagens obtidas para essa análise são fornecidas na figura 3.1, onde podem ser observadas células circulares (com fator de forma próximo da unidade) e células mais alongadas (com fator de forma bem menor que a unidade).

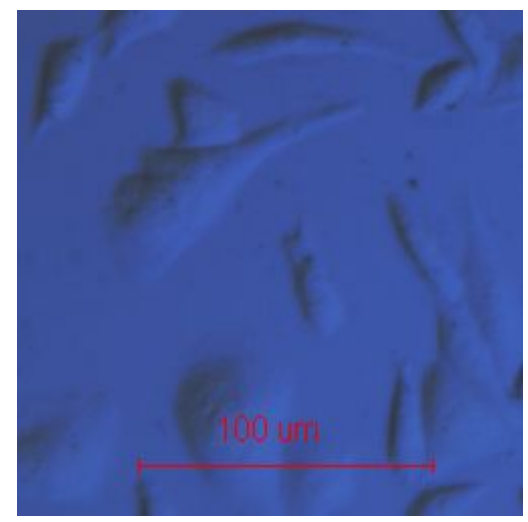

(a)

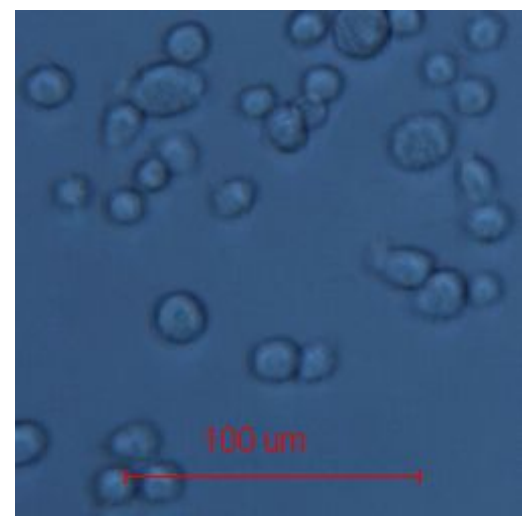

(b)

Figura 3.1: (a) Imagem de MO típica de células crescidas em SU-8, apresentando formato alongado, gerando fator de forma de $F_{f}=0,52$. (b) Imagem de MO típica de células crescidas em PDMS, apresentando formato circular, gerando um fator de forma de $F_{f}=0,98$. Barra de $100 \mu \mathrm{m}$.

Os valores médios dos fatores de forma $\left(F_{f}\right)$ de cada superfície são apresentados na tabela 3.1 , onde os materiais foram listados em ordem crescente do $F_{f}$. Para o vidro, o SU-8 liso e o DLC o fator de forma apresenta baixos valores, demonstrando um bom espraiamento das células nessas superfícies, o que representa boa adesão e adequação do material ao cultivo das células. Para a superfície de PDMS temos o valor unitário para $F_{f}$, que está relacionado a um baixo espraiamento das células, evidenciando pobre adesão e inadequação do material ao cultivo das células.

A energia de superfície (ES) foi medida para todos os substratos e os resultados são também apresentados na tabela 3.1. A energia de superfície obtida para o PDMS é compatível com o resultado de fator de forma $\left(F_{f}\right)$, uma vez que se obtêm o pior valor para ES confirmando a baixa adesão celular, o que promove a geração de células com elevado fator de forma $\left(F_{f}\right)$. A ES do DLC e SU-8 têm valores intermediários em comparação com PDMS e vidro, no entanto 
DLC e SU-8 apresentam fator de forma baixo, indicando boa adesão celular. Curiosamente, apesar da diferença significativa entre ES do SU-8, DLC e vidro, a diferença entre os fatores de forma não foram tão significativos.

Tabela 3.1: Energia de superfície e valores médios dos fatores de forma $\left(F_{f}\right)$ de 450 células, para cada uma das culturas realizadas sobre vidro, SU-8, DLC e PDMS sem tratamento prévio e sem a introdução de microestruturas.

\begin{tabular}{|c|c|c|}
\hline \multicolumn{3}{|c|}{ Fator de forma e Energia de Superfície } \\
\hline \hline Amostra & Fator de forma & Energia de Superfície (mN/m) \\
\hline Vidro & $0,50 \pm 0,03$ & $54 \pm 3$ \\
\hline SU-8 & $0,52 \pm 0,03$ & $35 \pm 1$ \\
\hline DLC & $0,54 \pm 0,03$ & $27 \pm 1$ \\
\hline PDMS & $0,99 \pm 0,01$ & $9 \pm 1$ \\
\hline
\end{tabular}

Na sequência do trabalho, foram realizadas modificações de superfícies por tratamento por plasma e implantação iônica e novas culturas celulares foram efetuadas. O SU-8 com superfície lisa foi utilizado como substrato para implantação iônica de prata. A dose utilizada foi de $1,2 \times 10^{16}$ átomos $/ \mathrm{cm}^{2}$ e a energia de implantação foi de $8 \mathrm{keV}$. O DLC sobre silício foi tratado com plasma de oxigênio e com plasma de hexafluoreto de enxofre, o que deve gerar superfícies com terminações de oxigênio e com terminações de flúor, respectivamente [4-6]. O PDMS não foi incluído no restante do trabalho, por se mostrar inadequado para cultura celular.

\subsubsection{Resultados para Tratamento por plasma.}

Superfícies de DLC tratadas com plasma de oxigênio (DLC-O) e com plasma de hexafluoreto de enxofre (DLC-F) foram utilizadas para cultura celular. Como referência foi utilizada uma superfície de DLC sem tratamento em plasma. Nas figuras 3.2a, 3.2b e 3.2c são apresentadas imagens típicas de células vivas e células mortas, que devem estar marcadas com trypan blue.

Os resultados de contagem são apresentados na figura 3.3 onde observamos que, em três experimentos independentes, o número de células vivas (viáveis) por unidade de área foi superior para a superfície tratada com plasma de oxigênio (DLC-O), quando comparado com a superfície tratada com plasma de hexafluoreto de enxofre (DLC-F). Na figura 3.4 são apresentados os resultados de contagem do número de células mortas por unidade de área, que foi superior na superfície de DLC-F, também para os três experimentos independentes. Entretanto esse número é inferior a $0,5 \%$ das células vivas por unidade de área o que não é representativo, em termos de desempenho na cultura celular. Quanto à superfície de referência (DLC sem 
tratada ao plasma), notamos comportamentos diferentes para cada um dos três experimentos independentes (veja figuras 3.3 e 3.4). Uma justificativa para esse fato consiste na possível aleatoriedade de espécies químicas presentes na superfície do DLC sem tratamento com plasma, o que levou a não reprodutibilidade dos resultados.

As superfícies DLC-F, DLC-O e DLC sem tratamento com plasma foram também analisadas através de microscopia de fluorescência, utilizando o marcador DAPI. Esta marcação possibilita a contagem dos núcleos das células, o que pode ser observado na figuras $3.2 \mathrm{~d}, 3.2 \mathrm{e}$ e 3.2f. Três resultados independentes de contagem de número de núcleos por unidade de área são apresentados na figura 3.5. Esses resultados confirmam os obtidos através do teste de viabilidade com o uso de trypan blue (figura 3.3). Assim, na figura 3.5 a superfície tratada com plasma de oxigênio (DLC-O), apresentou um maior número de núcleos por unidade de área, quando comparado à superfície tratada com plasma de hexafluoreto de enxofre (DLC-F). Da mesma forma que nos resultados obtidos pelo teste de viabilidade (figura 3.3), a superfície de DLC sem tratamento com plasma apresentou resultados aleatórios na contagem de núcleos por unidade de área (figura 3.5).

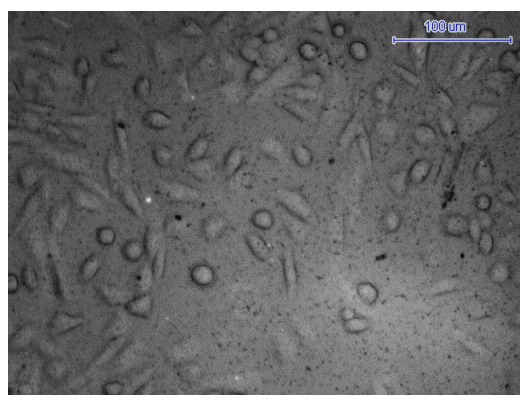

(a) DLC-O.

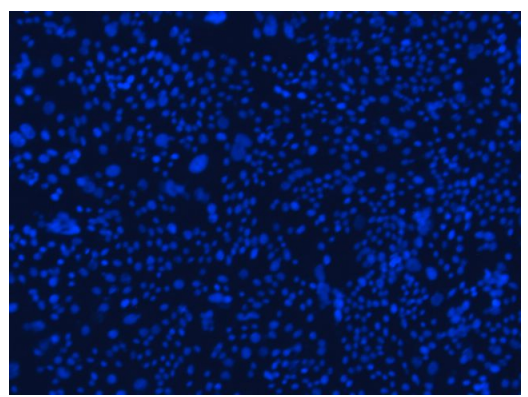

(d) DLC-O com DAPI.

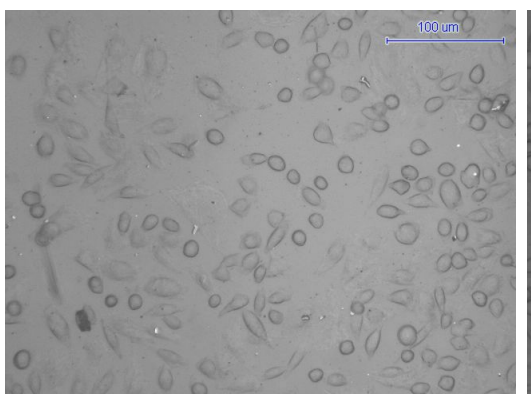

(b) DLC-F.

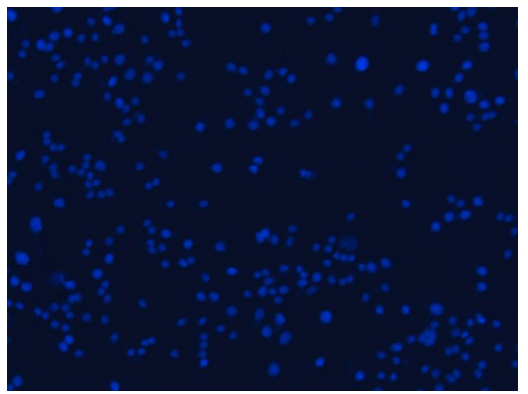

(e) DLC-F com DAPI.

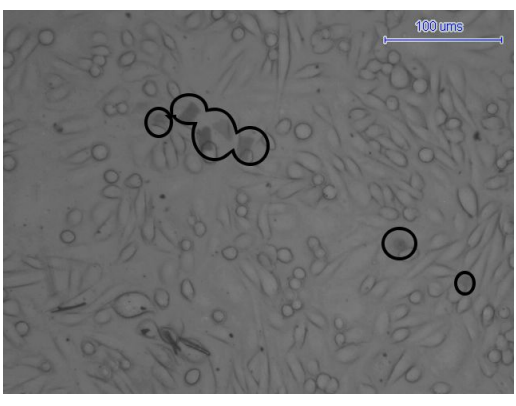

(c) DLC.

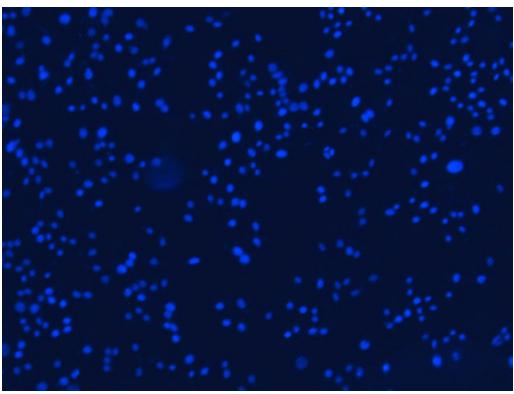

(f) DLC com DAPI.

Figura 3.2: Em (a), (b) e (c) temos uma imagem típica de MO das superfícies de DLC-O, DLCF e DLC, respectivamente, marcados com trypan blue. Os círculos indicam exemplos de células mortas. Em (e), (f) e (g) temos uma imagem típica de microscopia óptica de fluorescência das superfícies de DLC-O, DLC-F e DLC, respectivamente, marcados com o fluoróforo DAPI. As imagens marcadas com DAPI possuem tamanhos de $437 \times 328 \mu \mathrm{m}^{2}$ ou $0,17 \mu \mathrm{m} /$ pixel. 
Na figura 3.6 temos os valores das energias de superfície para as amostras de DLC-F, DLCO e DLC sem tratamento com plasma. Os resultados indicam que a superfície DLC-O é mais hidrofílica do que a superfície DLC-F, confirmando resultados já publicados pelo grupo [4-7]. É conhecido da literatura [170] que superfícies hidrofílicas apresentam melhor desempenho em cultura celular, o que é coerente com os resultados obtidos em nosso trabalho, onde a superfície DLC-O apresenta maior número de núcleos e maior número de células vivas por unidade de área, quando comparada à superfície DLC-F.
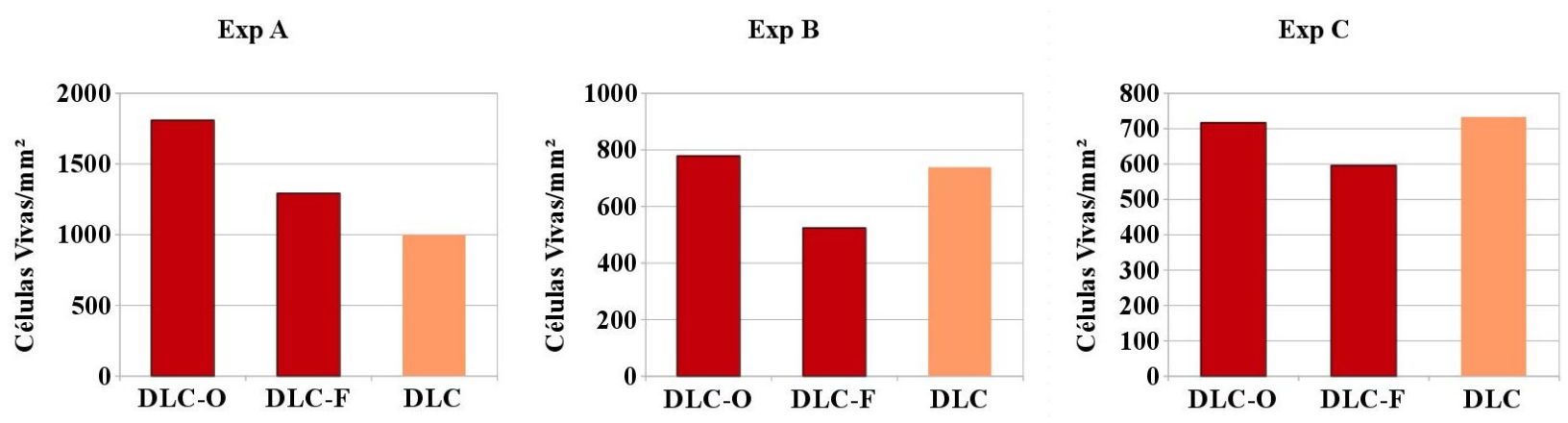

Figura 3.3: Número de células vivas por unidade de área em três experimentos independentes realizados sobre superfícies de DLC tratadas com plasma de oxigênio (DLC-O) e com plasma de hexafluoreto de enxofre (DLC-F). Como referência foi utilizada uma superfície de DLC sem tratamento em plasma.
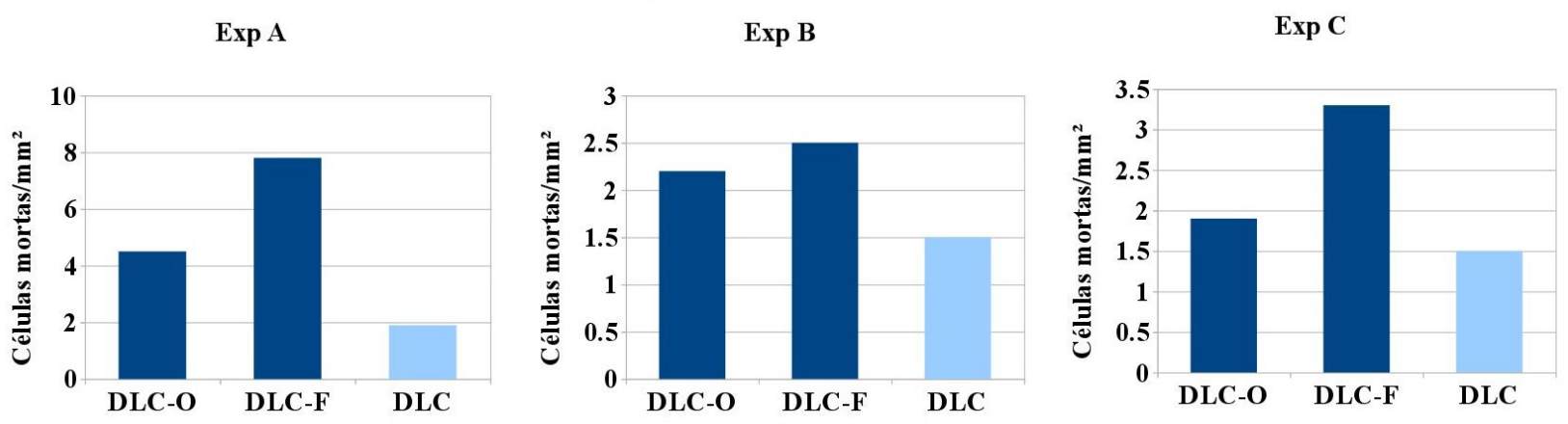

Figura 3.4: Número de células mortas por unidade de área em três experimentos independentes realizados sobre superfícies de DLC tratadas com plasma de oxigênio (DLC-O) e com plasma de hexafluoreto de enxofre (DLC-F). Como referência foi utilizada uma superfície de DLC sem tratamento em plasma. 

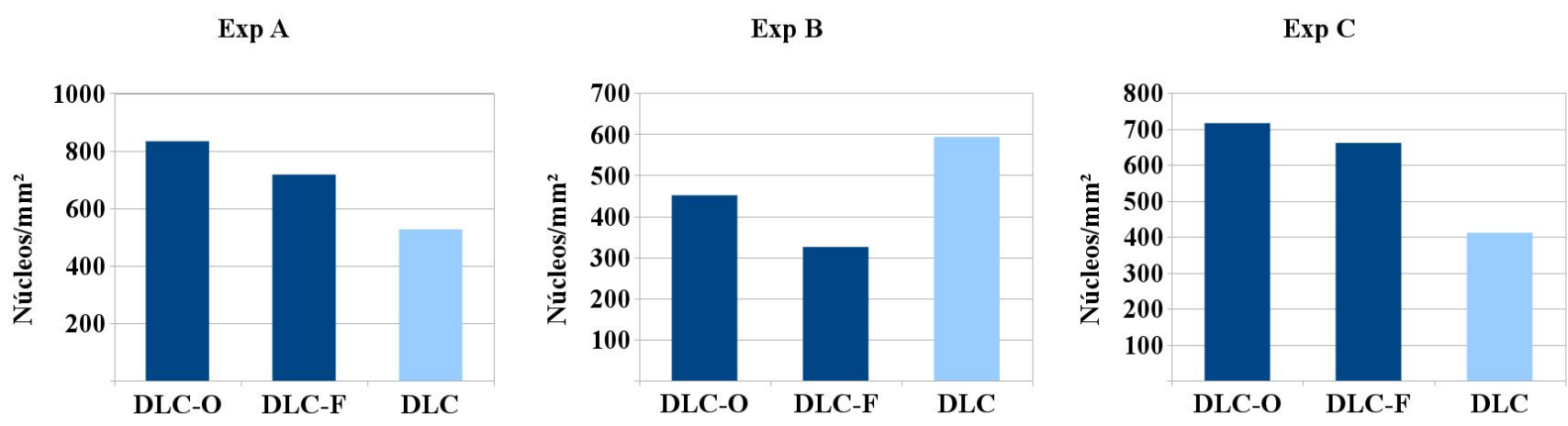

Figura 3.5: Número de núcleos por unidade de área marcados com DAPI em três experimentos independentes realizados sobre superfícies de DLC tratadas com plasma de oxigênio (DLC-O) e com plasma de hexafluoreto de enxofre (DLC-F). Como referência foi utilizada uma superfície de DLC sem tratamento em plasma.

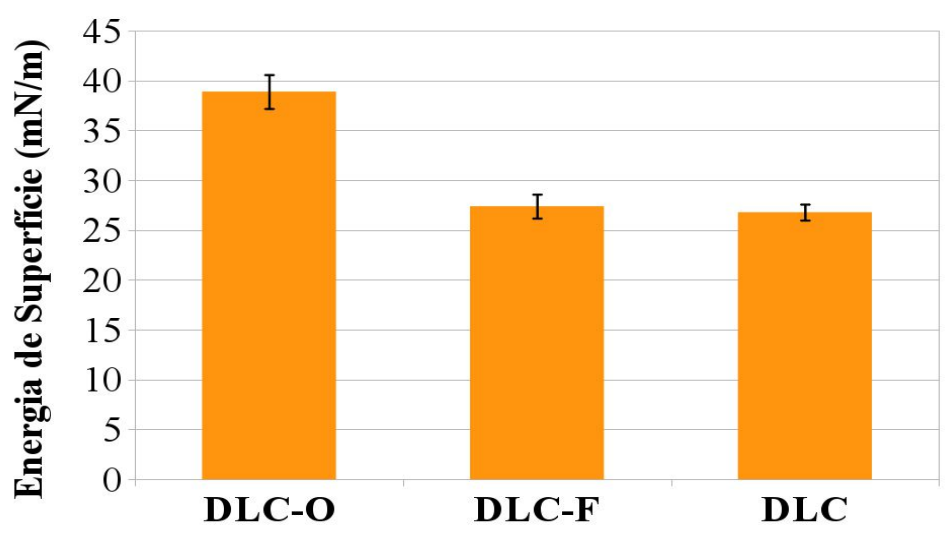

Figura 3.6: Energia de superfície obtida para as superfícies de DLC tratado com plasma de oxigênio (DLC-O), com plasma de hexafluoreto de enxofre (DLC-F) e DLC sem tratamento.

\subsubsection{Resultados de Implantação iônica.}

\subsubsection{Resultados da análise de RBS.}

Através da análise de RBS foi possível determinar a dose de implantação de prata $(A g)$ em SU-8. A dose medida foi de $1,2 \times 10^{16}$ átomos $/ \mathrm{cm}^{2}$. Conforme a tabela 3.2 vemos o percentual atômico obtido pela análise, onde, o $C$ é o substrato e o $A u$ é tido como um traço devido à implantações anteriores. Vemos da tabela 3.2 que há 2 átomos de $\mathrm{Ag}$ para cada átomo de oxigênio e supondo-se que todo oxigênio presente esteja ligado aos átomos de prata podemos esperar que o material implantado seja óxido de prata $\left(\mathrm{Ag}_{2} \mathrm{O}\right)$. 
Tabela 3.2: Valores percentuais dos elementos obtidos pela análise de RBS.

\begin{tabular}{|c|c|}
\hline \multicolumn{2}{|c|}{ Percentual atômico medido por RBS } \\
\hline \hline Elemento & Quantidade Percentual \\
\hline $\mathrm{Ag}$ & $1,94 \%$ \\
\hline $\mathrm{Au}$ & $0,009 \%$ \\
\hline $\mathrm{O}$ & $0,97 \%$ \\
\hline $\mathrm{C}$ & $97,08 \%$ \\
\hline Total & $100 \%$ \\
\hline
\end{tabular}

\subsubsection{Resultados para simulação numérica realizada no código TRIDYN.}

Através do código TRIDYN obteve-se o perfil de implantação em profundidade da fração de átomos de prata na matriz de SU-8. A figura 3.7 apresenta o perfil simulado por TRIDYN para a implantação de uma dose de $1,2 \times 10^{16}$ átomos $/ \mathrm{cm}^{2}$ de prata com energia de $8 \mathrm{keV}$ em superfície de SU-8. Pelo perfil apresentado, o máximo de fração de átomos de prata se encontra à cerca de $12 \mathrm{~nm}$ da superfície do SU-8 (localizada na origem do eixo $x$ de coordenadas do gráfico).

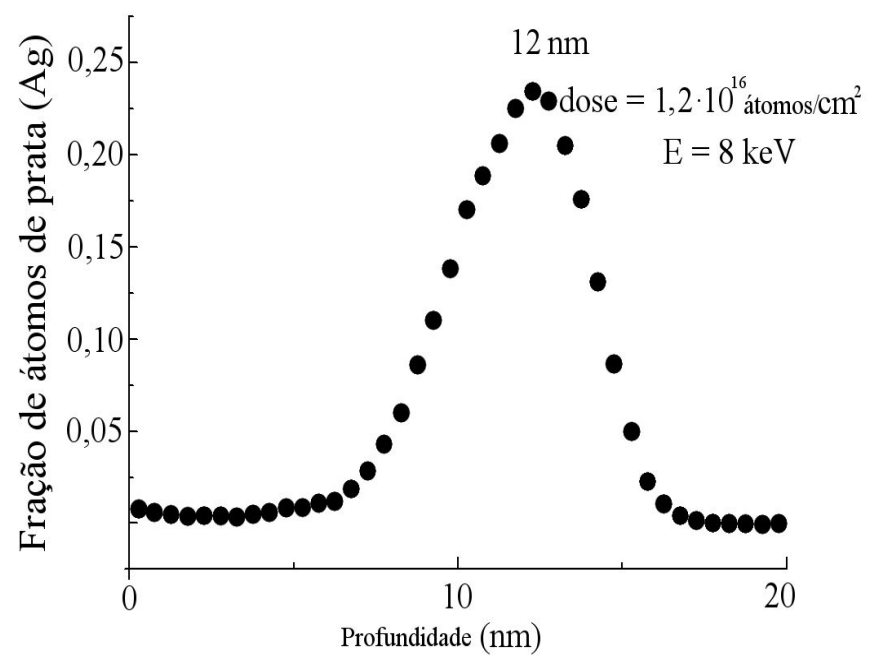

Figura 3.7: Fração dos átomos implantados em função da profundidade obtida pelo código TRIDYN.

\subsubsection{Resultados da cultura de células nas superfícies modificadas por implantação iônica.}

Culturas celulares foram realizadas em SU-8 com superfície lisa onde foi implantada uma dose de $1,2 \times 10^{16}$ átomos $/ \mathrm{cm}^{2}$ de prata com uma energia de $8 \mathrm{keV}$. Como referência foi utilizada uma superfície lisa de SU-8, sem implantação. Os resultados são apresentados na figura 
3.8 onde notamos que, em três experimentos independentes, o número de células vivas (viáveis) por unidade de área foi superior na superfície de SU-8 com prata implantada, mostrando o bom desempenho da cultura nesse substrato. Na figura 3.9 são apresentados os resultados do número de células mortas por unidade de área que foi superior na superfície de SU-8 com prata implantada. No entanto, considerando-se que esse número é inferior a $1 \%$ das células vivas por unidade de área, ainda assim, a implantação de prata em SU-8 se mostrou com melhor desempenho para a cultura celular.
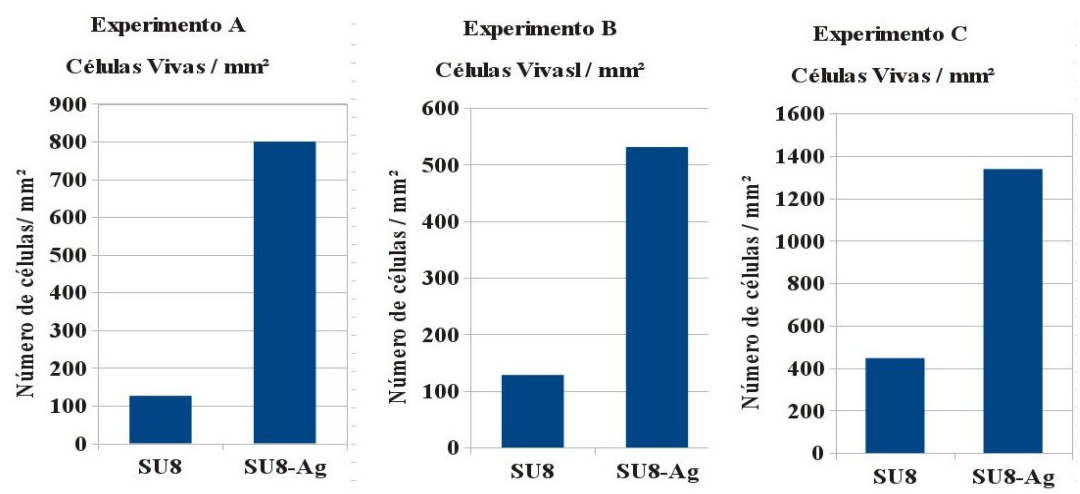

Figura 3.8: Número de células vivas por unidade de área em três experimentos independentes realizados sobre superfície lisa de SU-8 com implantação de $1,2 \times 10^{16}$ átomos $/ \mathrm{cm}^{2}$ de prata com energia de $8 \mathrm{keV}$. Como referência foi utilizada uma superfície lisa de SU-8, sem implantação.
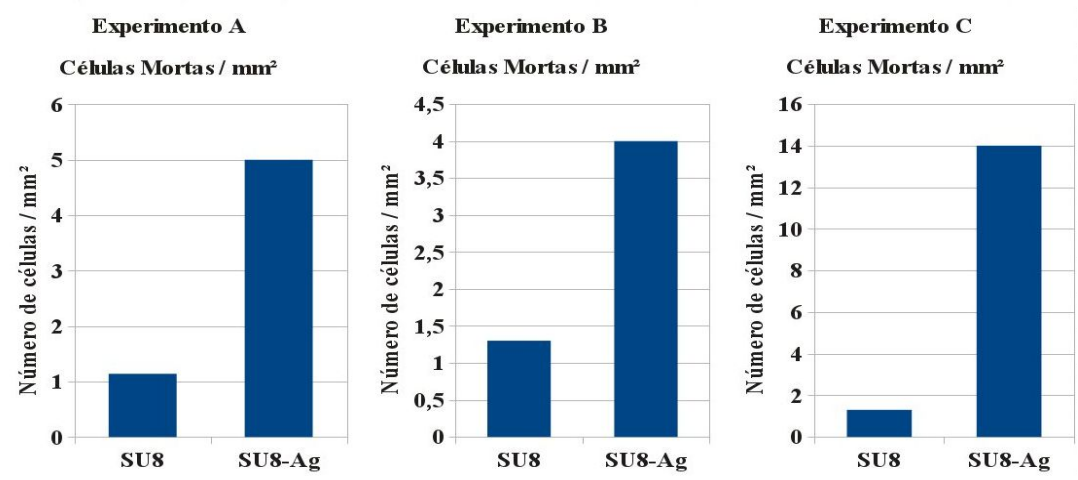

Figura 3.9: Número de células mortas por unidade de área em três experimentos independentes realizados sobre superfície lisa de SU-8 com implantação de $1,2 \times 10^{16}$ átomos $/ \mathrm{cm}^{2}$ de prata com energia de $8 \mathrm{keV}$. Como referência foi utilizada uma superfície lisa de SU- 8 , sem implantação.

A seguir, serão feitas análises complementares para tentarmos justificar os resultados aqui obtidos. 


\subsubsection{Resultados de energia de superfície e AFM para superfície modifi- cadas por implantação.}

A energia livre de superfície foi determinada a partir de medições do ângulo de contato para o SU-8 $(35 \pm 1 \mathrm{mN} / \mathrm{m})$ e para o SU-8/Ag $(30 \pm 1 \mathrm{mN} / \mathrm{m})$. A diferença entre os valores é demasiadamente baixa para justificar uma diferença de comportamento das células em suas superfícies. A Figura 3.10 apresenta uma micrografia de AFM da superfície do material SU-8 sem implantação de prata. Na figura 3.11 é apresentado uma micrografia de AFM do SU8 quando este teve sua superfície modificada pela implantação de prata. É possível observar que a superfície do SU-8 após a implantação é nanoestruturada apresentando rugosidade de $R q=1,1 \mathrm{~nm}$ enquanto que a rugosidade do SU-8 original é de $R q=0,5 \mathrm{~nm}$. Sabe-se no entanto, que as superfícies nanoestruturadas pode interferir com o crescimento de células apenas quando as estruturas têm razão de aspecto próximo da unidade [171], o que não ocorre. O tamanho lateral das estruturas foram em média de $40 \mathrm{~nm}$, e as alturas foram $5 \mathrm{~nm}$, dando uma razão de aspecto de 0,13. No que diz respeito à área de superfície, o SU-8/Ag tem uma área de 6,7\% mais elevada do que o original SU-8, que é compatível com a baixa razão de aspecto das estruturas. Desta forma, estas nanoestruturas não devem justificar também o comportamento diferente de células na superfície SU-8/Ag.

É conhecido que mediante implantação iônica de um metal em polímero, excedendo o limite de solubilidade da matriz polimérica, nanopartículas do metal nucleiam e crescem com o aumento da dose implantada [172]. Assim, os resultados aqui obtidos possivelmente podem ser justificados pela formação de nanopartículas de óxido de prata logo abaixo da superfície de SU-8, mais precisamente a cerca de $12 \mathrm{~nm}$, como obtido na simulação por TRIDYN. Assim, uma possível razão para o melhor desempenho para o crescimento celular em SU-8/Ag é a possibilidade das nanopartículas de prata exercerem algum tipo de interação com as células. Nós sugerimos que provavelmente seja potencial de superfície. 


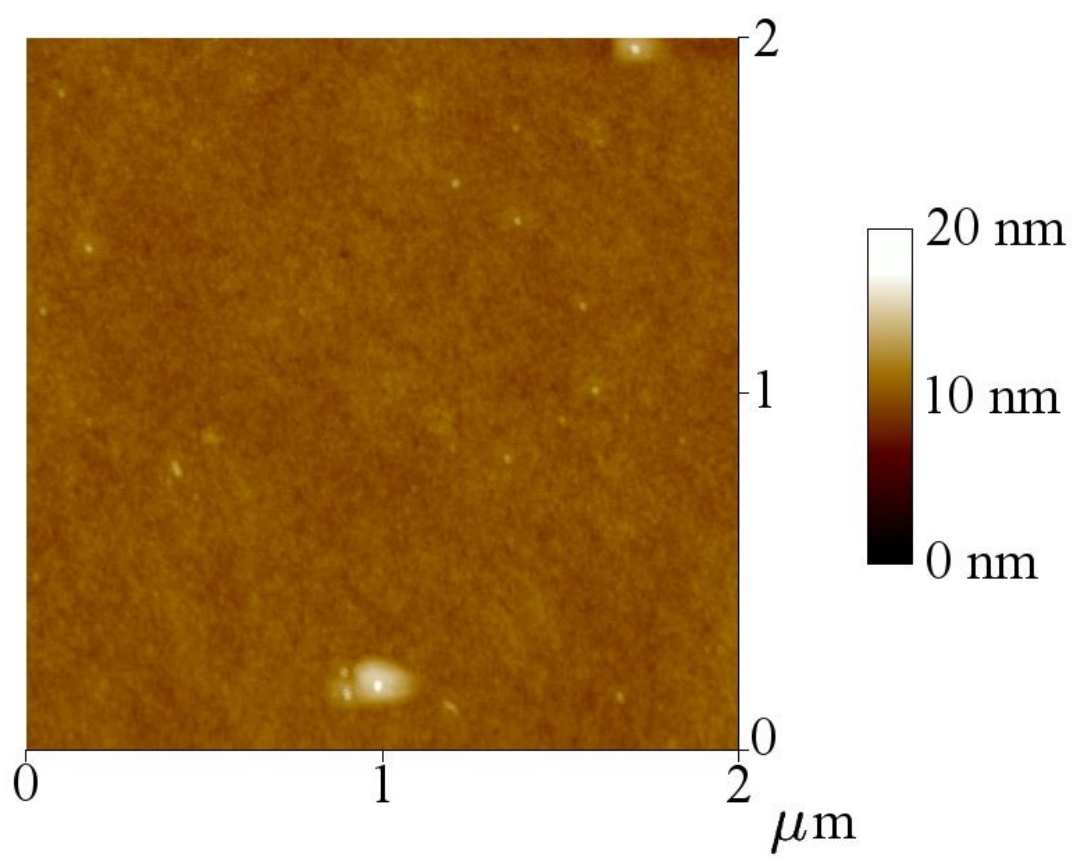

Figura 3.10: Micrografia AFM da superfície original de SU-8.

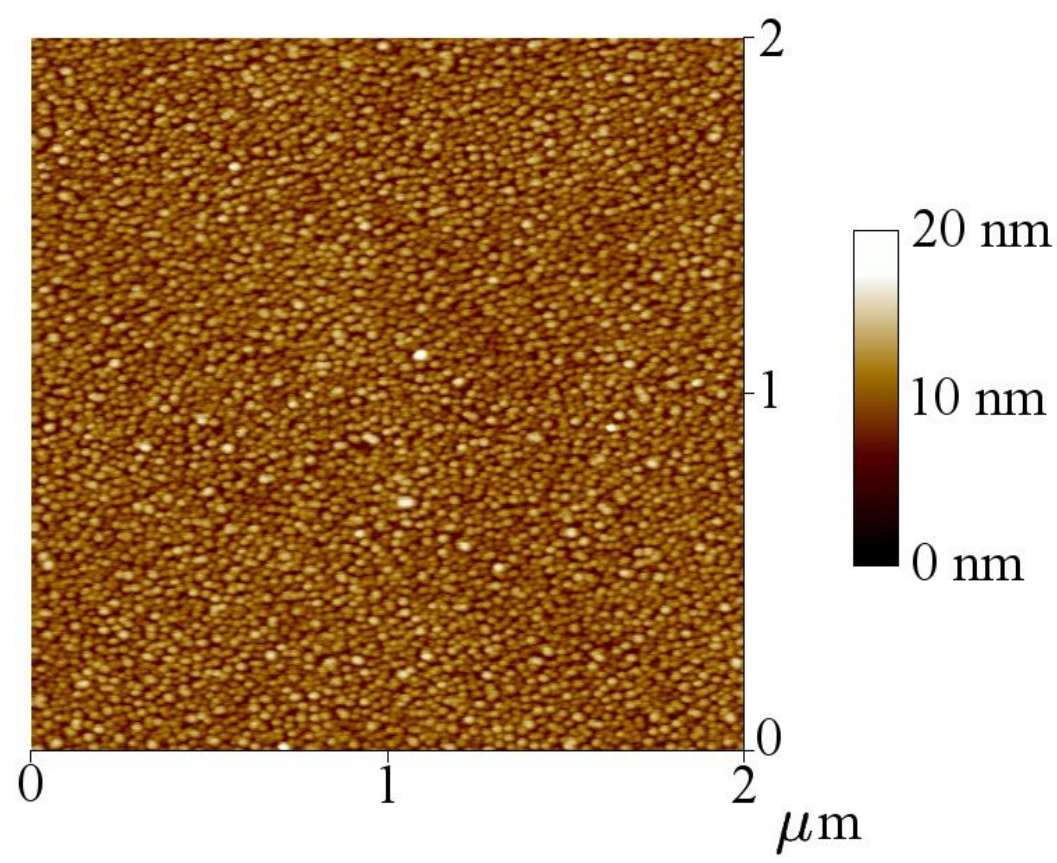

Figura 3.11: Micrografia AFM da superfície de SU-8 modificada pela implantação de Ag. 


\subsection{Resultados para as superfícies microestruturadas.}

As amostras de SU-8 foram litografados por feixe de elétrons, introduzindo em suas superfícies estruturas periódicas na forma de cavidades hexagonais. Na figura 3.12 são mostradas as superfícies produzidas com as geometrias hexagonais periódicas nas dimensões apresentados na tabela 3.3.

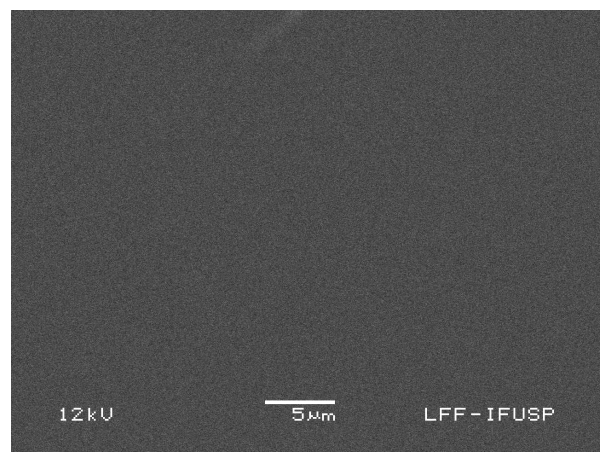

(a) Superfície do SU-8.

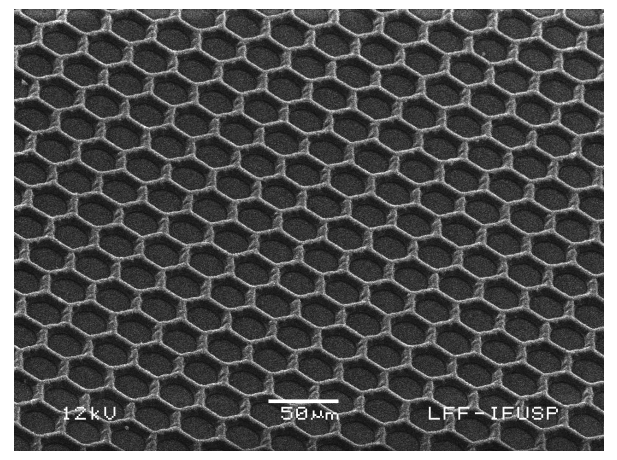

(c) HEX-30.

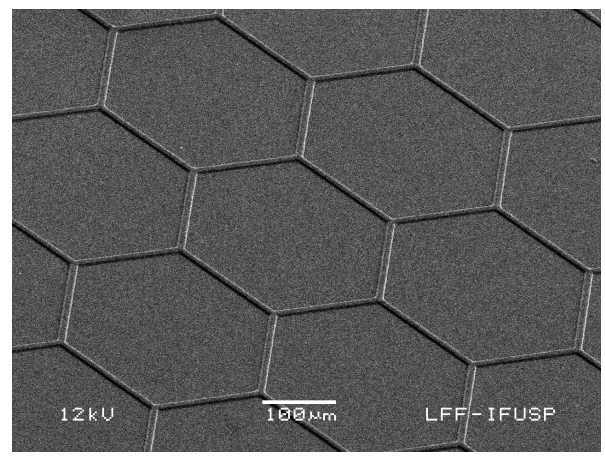

(e) HEX-280.

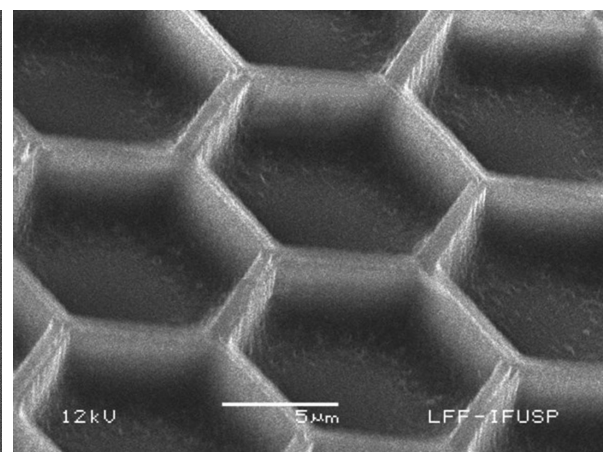

(b) HEX-12.

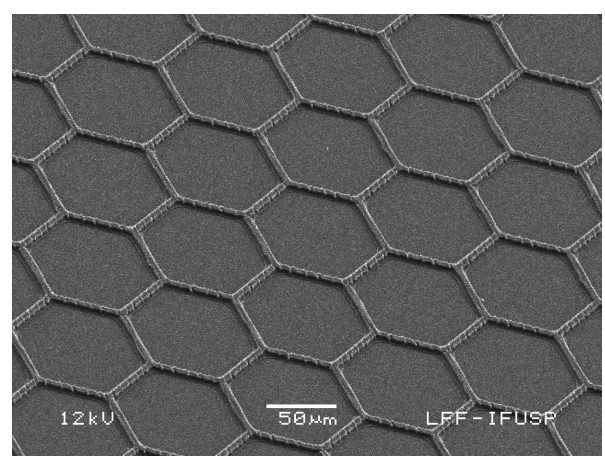

(d) HEX-80.

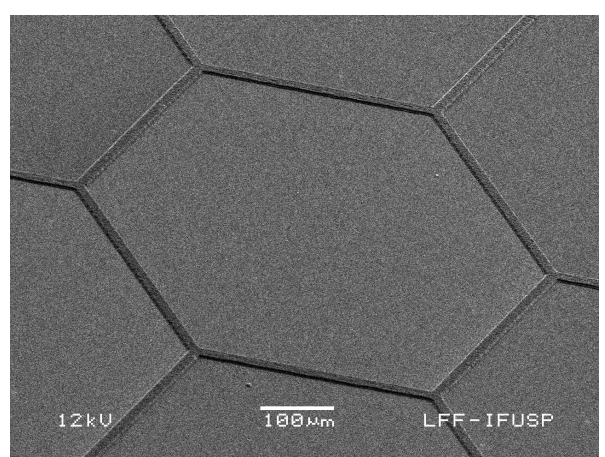

(f) HEX-560.

Figura 3.12: Micrografias de MEV mostrando na figura (a) a superfície do material SU-8 originalmente depositado. Na figura (b) é apresentado para HEX-12, na figura (c) para HEX-30, na figura (d) para HEX-80, na figura (e) para HEX-280 e na figura (f) para HEX-560.

A seguir apresentaremos os resultados para os seguintes experimentos: (1) Cultura de células $\mathrm{CHO}$ em superfícies de SU-8 contendo estruturas hexagonais com diâmetro $(2 R)$ da- 
Tabela 3.3: Parâmetros de fabricação obtidos por medidas realizadas em MEV e AFM para a cavidades hexagonais nos diversos diâmetros.

\begin{tabular}{|c|c|c|c|}
\hline \multicolumn{4}{|c|}{ Parâmetros de fabricação das microcavidades. } \\
\hline$\overline{\text { Cavidade }}$ & Diâmetro $(2 R)$ & $\overline{\bar{\beta}}$ & Altura $(h)$ \\
\hline HEX-12 & $12 \mu \mathrm{m}$ & $1,3 \mu \mathrm{m}$ & $3,0 \mu \mathrm{m}$ \\
\hline HEX-30 & $30 \mu \mathrm{m}$ & $2,0 \mu \mathrm{m}$ & $3,0 \mu \mathrm{m}$ \\
\hline HEX-80 & $80 \mu \mathrm{m}$ & $3,5 \mu \mathrm{m}$ & $3,0 \mu \mathrm{m}$ \\
\hline HEX-280 & $280 \mu \mathrm{m}$ & $6,5 \mu \mathrm{m}$ & $3,0 \mu \mathrm{m}$ \\
\hline HEX-560 & $560 \mu \mathrm{m}$ & $9,0 \mu \mathrm{m}$ & $3,0 \mu \mathrm{m}$ \\
\hline & 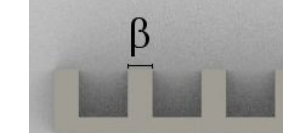 & & \\
\hline
\end{tabular}

dos pelos valores de $12 \mu \mathrm{m}, 30 \mu \mathrm{m}, 80 \mu \mathrm{m}, 270 \mu \mathrm{m}$ e $560 \mu \mathrm{m}$. O parâmetro $h$ foi mantido constante e dado por $h=3 \mu \mathrm{m} \operatorname{com} \beta$ dado conforme a tabela 3.3. Estas superfícies foram semeadas com o valor de $1,2 \times 10^{5}$ células por poço e caracterizadas por microscopia óptica de fluorescência onde os núcleos foram marcados com o fluoróforo DAPI. Que neste caso, foi necessário o aumento do número de células semeadas pois a análise através dos núcleos marcados exige maior aumento nas imagens obtidas e, portanto, fez-se necessário uma maior densidade de células por área (veja Apêndice C). Para tal registrou-se 10 imagens de $437 \times 328 \mu \mathrm{m}^{2}$ (um total em área analisada de $1,43 \mathrm{~mm}^{2}$ ) em cada uma das superfícies para cada um dos três experimentos independentes. Caracterizamos estas superfícies com relação ao número de núcleos por unidade de área, isto é, núcleos $/ \mathrm{mm}^{2}$. (2) Cultura de células CHO em superfícies de SU8 contendo novamente estruturas hexagonais com diâmetro $(2 R)$ de $12 \mu \mathrm{m}, 80 \mu \mathrm{m}, 270 \mu \mathrm{m}$ e $560 \mu \mathrm{m}$. Estas superfícies foram semeadas com o valor de $6 \times 10^{4}$ células por poço e caracterizadas por microscopia óptica com relação ao número de células viáveis (celulas mortas identificadas pelo marcador trypan blue) por unidade de área, ou seja, células $/ \mathrm{mm}^{2}$. Para tal registrou-se 5 imagens que resultam em $2 \mathrm{~mm}^{2}$ para cada uma das superfície para cada um dos 3 experimentos independentes.

\subsubsection{Resultados para as superfície microestruturadas análisadas por Microscopia Óptica de fluorescência.}

Para a realização das culturas celulares, as amostras/superfícies permaneceram imersas em álcool 70\% durante o tempo de 40 minutos imediatamente antes da semeadura das células CHO. Foram então semeadas $1,2 \times 10^{5}$ células por poço em 18 poços contendo os substratos em triplicata com as superfícies modificadas e mais um substrato com superfície de SU-8 liso. Após 
24 horas de incubação, a $37^{\circ} \mathrm{C}$ e em atmosfera úmida com injeção de $5 \%$ de $\mathrm{CO}_{2}$, as células em cada uma das superfícies foram analisadas por microscopia óptica de fluorescência com marcação dos núcleos por meio do fluoróforo DAPI. Os experimentos foram sempre realizados com as células em crescimento exponencial e sempre com as culturas entre a $3^{a}$ e a $5^{a}$ passagem, ou seja, as celulas encontravam-se entre o $3^{\circ}$ e o $7^{\circ}$ dia de cultura.

Na figura 3.13 temos como exemplo micrografias de microscopia óptica de fluorescência típicas obtidas para as culturas realizadas nas superfícies litografadas HEX-12, HEX-30, HEX80, HEX-280, HEX-560 e SU-8 liso. Após 24 h de cultura as células foram fixadas e seus núcleos foram marcados com o fluoróforo DAPI.

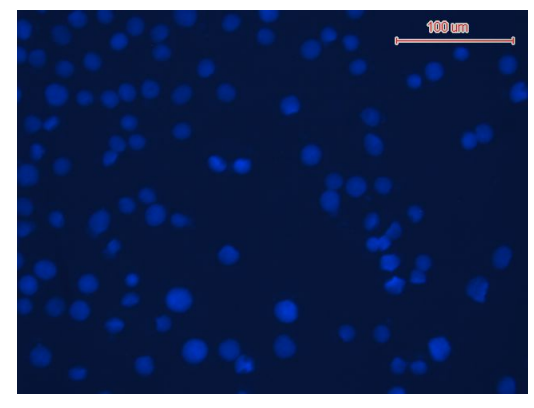

(a) SU-8 liso.

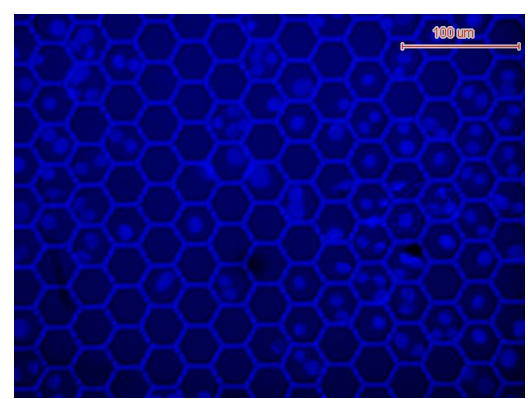

(c) HEX-30.

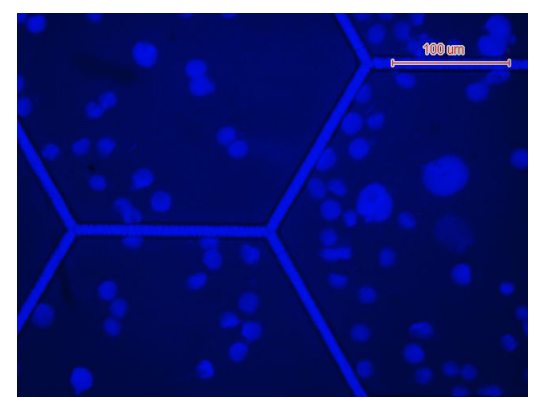

(e) HEX-280.

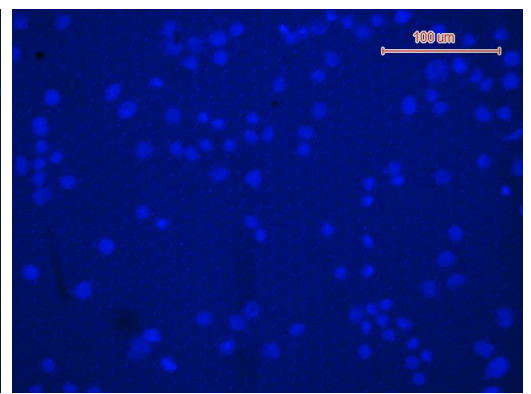

(b) HEX-12.

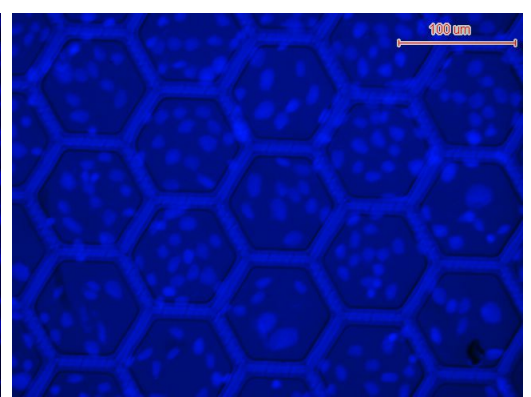

(d) HEX-80.

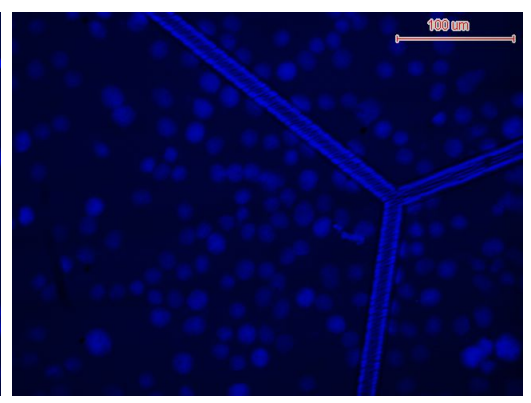

(f) HEX-560.

Figura 3.13: Imagens típicas da cultura de células realizada e os núcleos marcados pelo fluoróforo DAPI nas seguintes superfícies: (a) SU-8 liso, (b) HEX-12, (c) HEX-30 (d) HEX-80 (e) HEX-280 e (f) HEX-560. A barra indica $100 \mu \mathrm{m}$ 
Apresentamos na figura 3.14 histogramas com o número médio de núcleos por $\mathrm{mm}^{2}$ em três experimentos independentes para as superfícies litografadas na dimensões que são apresentados na tabela 3.3. Esses resultados mostram que o número de núcleos por unidade de área foi consideravelmente maior para HEX-80, como ilustrado na figura 3.13d. O tamanho médio das células CHO quando estavam espraiadas era entre 40 e $75 \mu \mathrm{m}$. Assim, o argumento para uma menor proliferação das células nas superfícies contendo cavidades periódicas de $2 R=12$ e $30 \mu \mathrm{m}$ pode ser justificado pela dificuldade das células $\mathrm{CHO}$ aderirem na superfície, desde que uma célula espraiada ocuparia diversas estruturas do substrato. Para os substratos HEX-80, HEX-280 e HEX-560 observamos pelas imagens da figura 3.13 que os núcleos ocupavam preferencialmente áreas interiores às cavidades. Este fato sugere não haver dificuldade na adesão devido às microestruturas. No entanto, há um excelente desempenho da cultura celular para a dimensão de cavidade de $2 R=80 \mu \mathrm{m}$, quando comparado ao desempenho das culturas realizadas nas superfícies dos substratos HEX-280 e HEX-560 (ver figura 3.14). Note ainda que o número de núcleos por unidade de área dos substratos HEX-280 e HEX-560 são próximos ao valor obtido para o SU-8 liso. Este fato pode ser justificado considerando que as dimensões das estruturas, quando comparadas com os tamanhos das células, aproximam o substrato de uma superfície lisa.

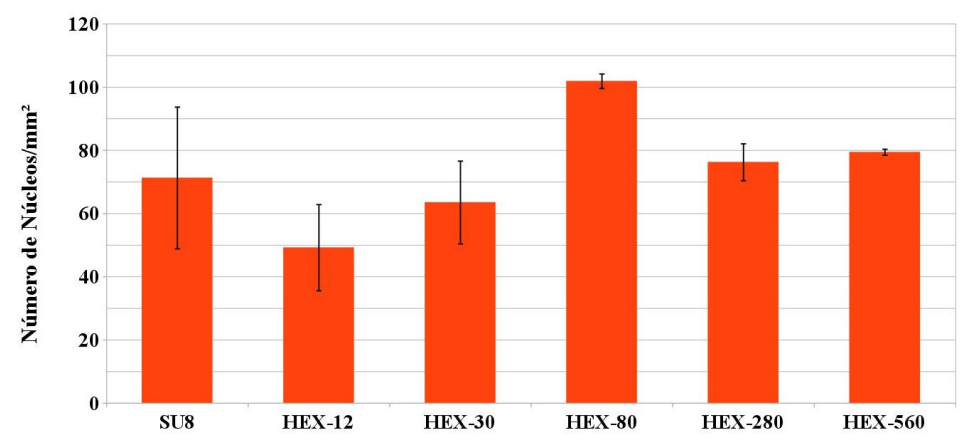

Figura 3.14: Cultura celular realizada em SU-8 liso, HEX-12, HEX-30, HEX-80, HEX-280 e HEX-560, quantificados através da contagem de núcleos marcados com DAPI. São apresentados valores médios e barras de erro de três experimentos independentes.

\subsubsection{Resultados para as superfície microestruturadas análisadas por Microscopia Óptica.}

Para a realização das culturas celulares, as amostras/superfícies permaneceram imersas em álcool $70 \%$ durante o tempo de 40 minutos imediatamente antes da semeadura das células CHO. Foram então semeadas $6 \times 10^{4}$ células em 15 poços contendo os substratos em triplicata com as superfícies de HEX-12, HEX-80, HEX-280, HEX-560 e SU-8 liso. Após 24 horas 
de incubação, a $37^{\circ} \mathrm{C}$ e em atmosfera úmida com injeção de $5 \%$ de $\mathrm{CO}_{2}$, as células em cada uma das superfícies foram analisadas por microscopia óptica (MO) para avaliação da viabilidade celular (utilizando marcador trypan blue). Os experimentos foram sempre realizados com as células em crescimento exponencial e sempre com as culturas entre a $3^{a}$ e a $5^{a}$ passagem, ou seja, as células encontravam-se entre o $3^{\circ}$ e o $7^{\circ}$ dia de cultura. A seguir, nas figuras apresentamos micrografias de MO típicas obtidas para as culturas realizadas nas superfícies litografadas HEX-12 (figura 3.16), HEX-80 (figura 3.17), HEX-280 (figura 3.18) , HEX-560 (figura 3.19) e SU-8 liso (figura 3.15).

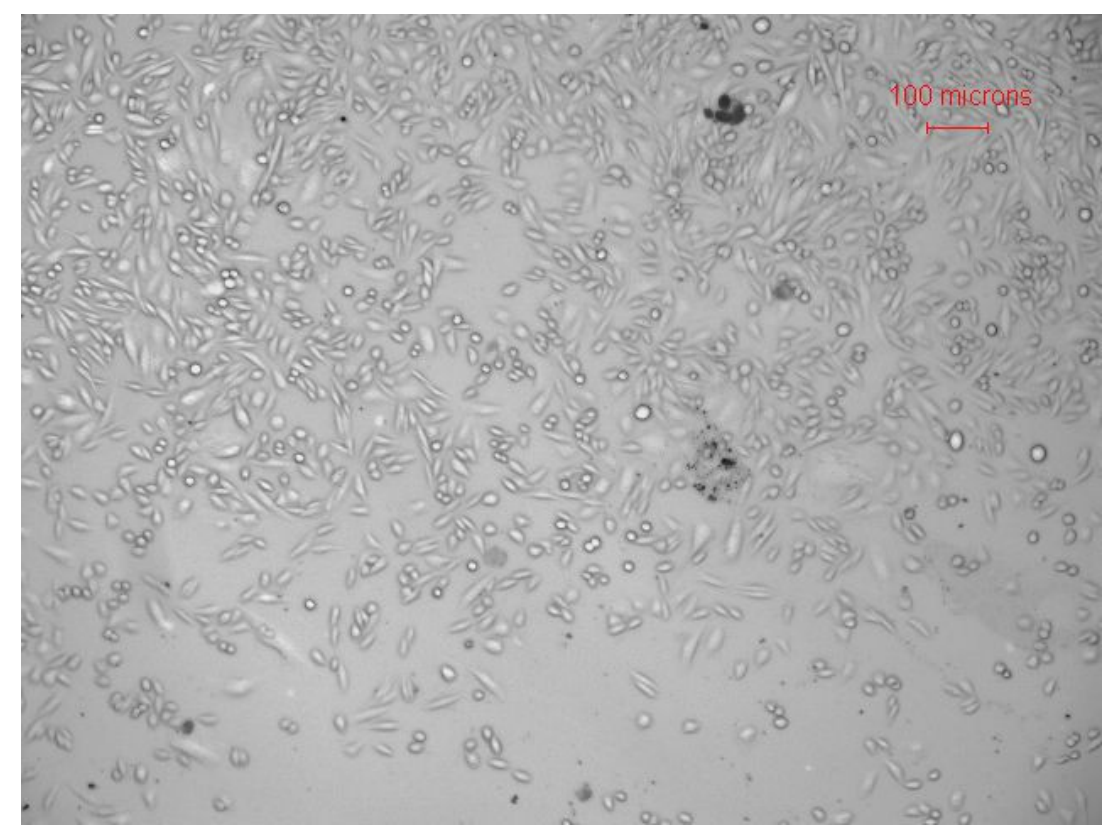

Figura 3.15: Imagem típica da cultura de células marcadas com trypan blue em SU-8 liso. A barra indica $100 \mu \mathrm{m}$. 


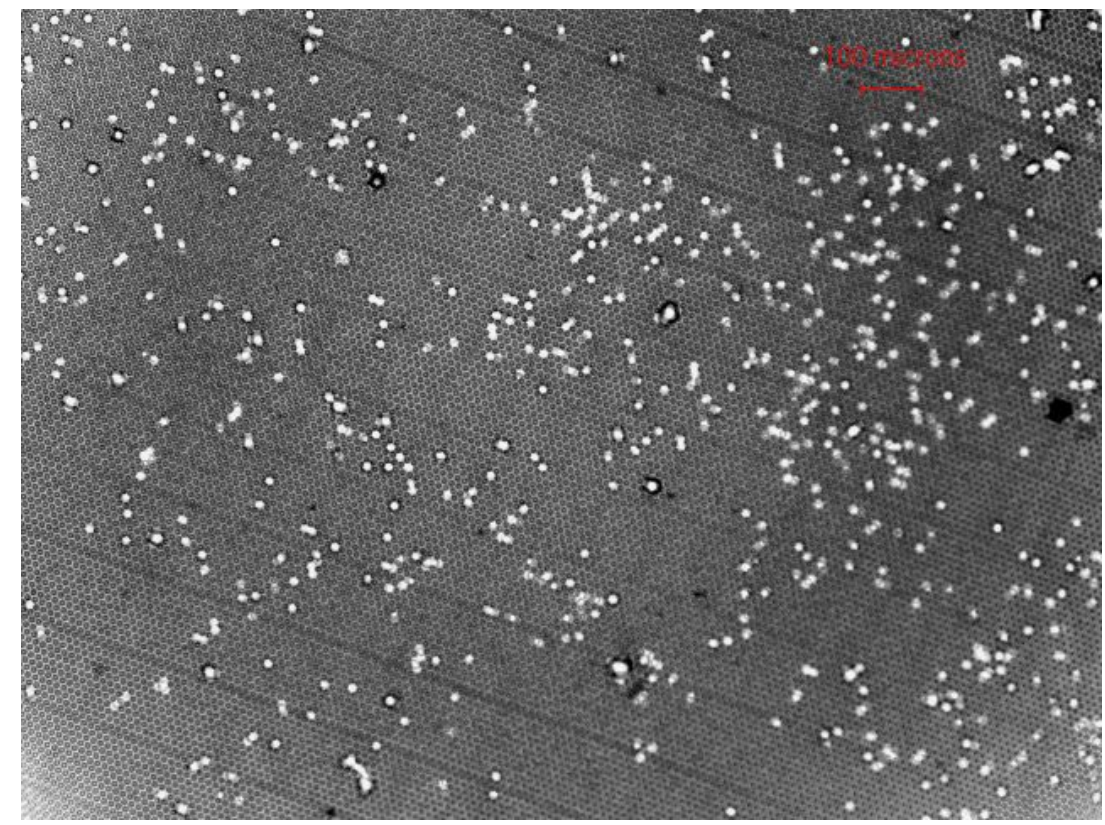

Figura 3.16: Imagem típica da cultura de células marcadas com trypan blue no substrato HEX12. A barra indica $100 \mu \mathrm{m}$.

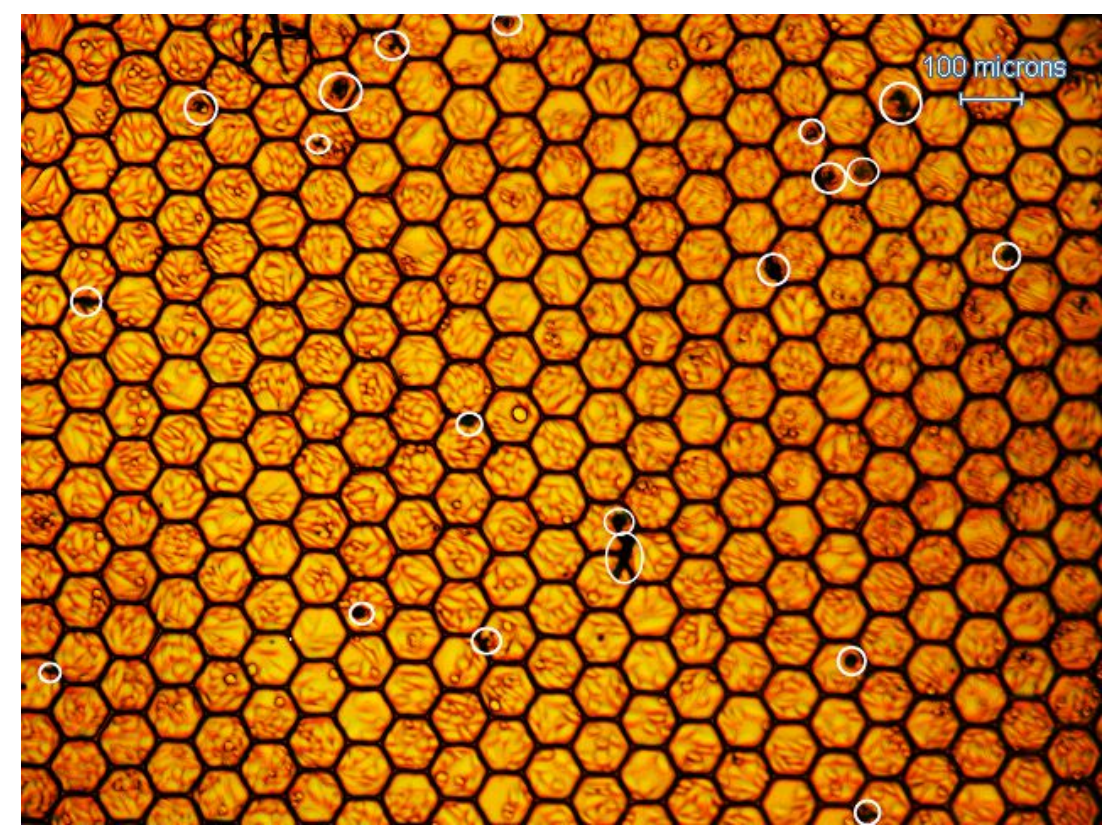

Figura 3.17: Imagem típica da cultura de células marcadas com trypan blue no substrato HEX80. Os círculos indicam células marcadas e a barra indica medida de $100 \mu \mathrm{m}$. 


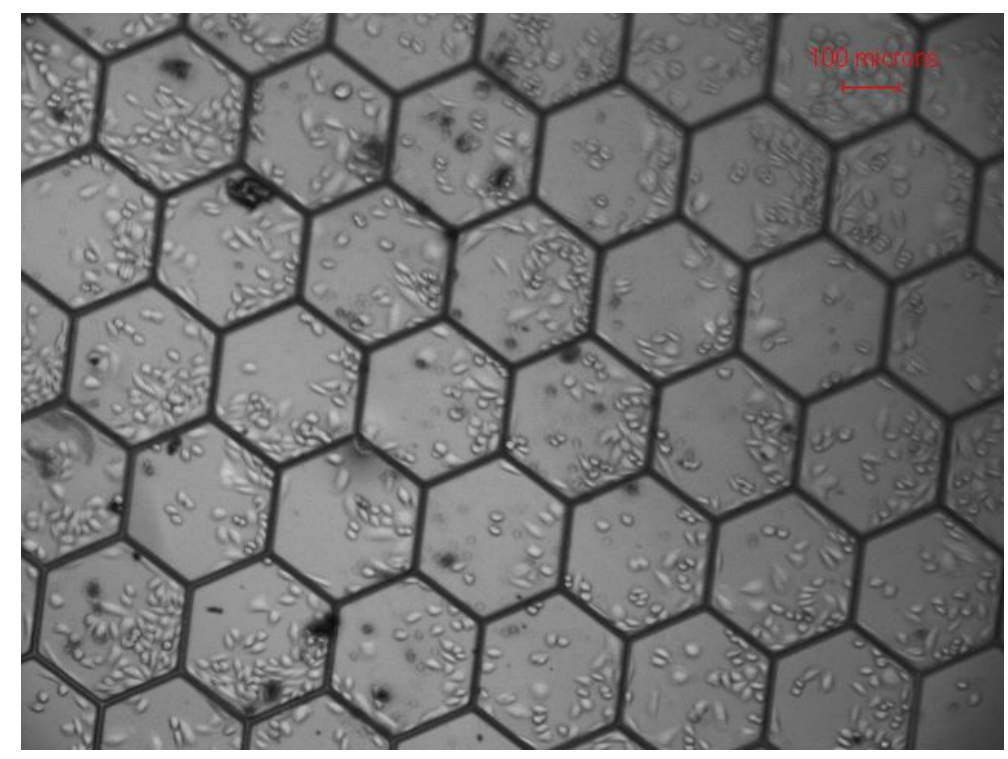

Figura 3.18: Imagem típica da cultura de células marcadas com trypan blue no substrato HEX280. A barra indica $100 \mu \mathrm{m}$.

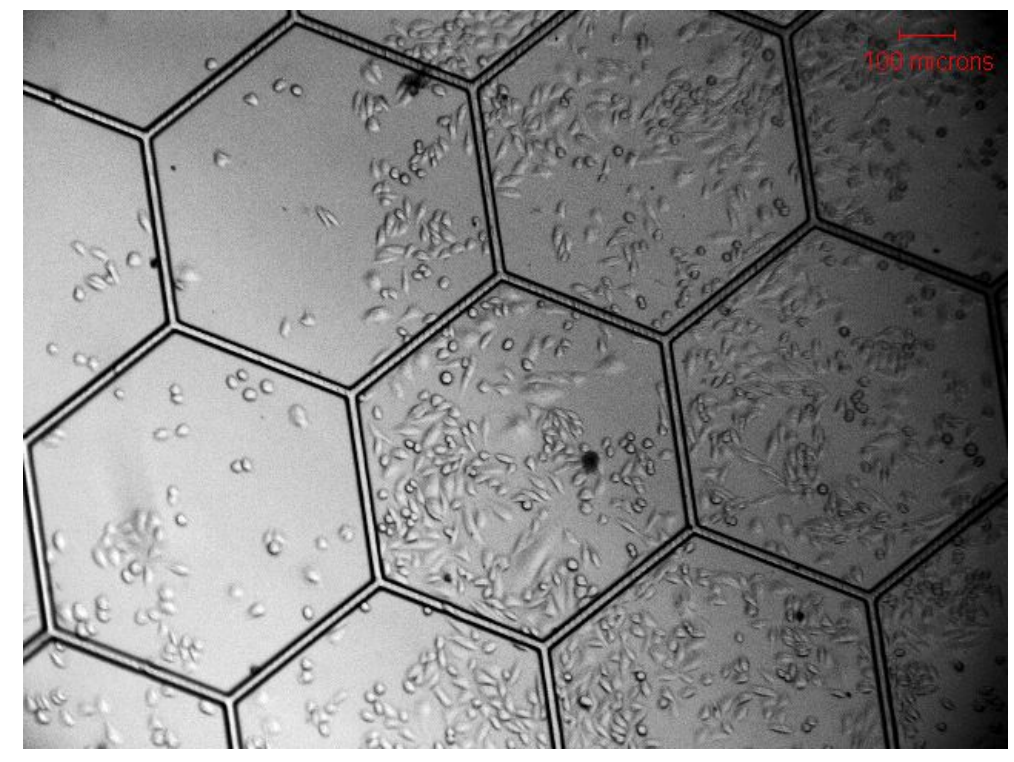

Figura 3.19: Imagem típica da cultura de células marcadas com trypan blue no substrato HEX560. A barra indica $100 \mu \mathrm{m}$.

A figura 3.20 apresenta histograma com os valores totais de células vivas $/ \mathrm{mm}^{2}$ para as culturas celulares apresentadas nas figuras 3.15, 3.16, 3.17, 3.18 e 3.19, valores médios para três experimentos independentes. O histograma da figura 3.20 (utilizando marcação com triplanblue) corrobora os resultados apresentados no histograma da figura 3.14 (utilizando marcação com DAPI). Assim, fica confirmado o melhor desempenho da cultura celular no substrato HEX80 que apresentou o maior número de células vivas $/ \mathrm{mm}^{2}$. Note que as figuras 3.15, 3.16, 3.17, 
3.18 e 3.19 apresentam imagens das células nas superfícies dos substratos em estudo, diferentemente da figura 3.13 que apresenta imagens dos núcleos dessas células. Assim, podemos ainda extrair das figuras 3.15, 3.16, 3.17, 3.18 e 3.19 como as células se acomodam nas estruturas hexagonais litografadas. No substrato HEX-12 (figura 3.16) as células se apresentam prioritariamente esféricas e aderidas, muitas vezes, em uma única estrutura hexagonal, comprovando a baixa adesão. Nos demais substratos (figuras 3.15, 3.17, 3.18 e 3.19) as células se apresentam majoritariamente espraiadas, mas claramente a maior proliferação se deu no caso do substrato HEX-80 (figura 3.17).

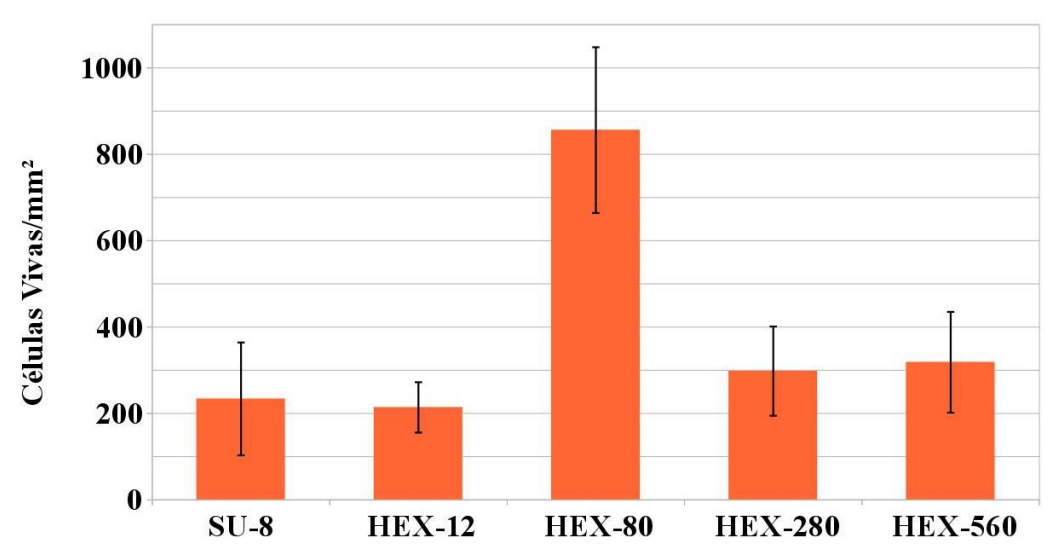

Figura 3.20: Valores médios do número de células vivas por unidade de área para três experimentos independentes realizados sobre superfícies de SU-8 liso e substratos HEX-12, HEX-80, HEX-270 e HEX-560, conforme a tabela 3.3.

Todas as superfícies litografadas de experimentos preliminares, mostraram ser não citotóxicas por apresentarem um percentual inferior a $1 \%$ de células mortas (apoptose ou necrose), o que não é representativo.

Outro experimento envolvendo amostras microestruturadas em SU-8 foi planejado para a avaliação de cultura celular na presença de degraus na superfície. Assim, uma amostra de SU-8 foi litografada utilizando a geometria hexagonal, mas com valor de $\beta$ ampliado para dezenas de micrômetros. A amostra foi litografada de forma que $40 \%$ da superfície ficasse em um nível abaixo do restante dela, sendo o desnível de $3 \mu \mathrm{m}$ (que corresponde ao valor de $h$ ), como ilustra a figura 3.21. A avaliação das culturas realizadas nos substratos descritos foi feita através da contagem do número de células vivas por unidade de área do substrato, utilizando o marcador trypan blue. Os resultados obtidos são apresentados na tabela 3.4. 
Tabela 3.4: Células vivas por unidade de área, para três experimentos independentes, para culturas celulares realizadas em amostra microestruturada em SU-8 com geometria periódica na forma de cavidades hexagonais com parâmetros $2 R=82 \mu \mathrm{m}, \beta=37 \mu \mathrm{m}$ e $h=3 \mu \mathrm{m}$.

\begin{tabular}{|c|c|c|c|}
\hline Células vivas/mm $^{2}$ & Experimento A & Experimento B & Experimento C \\
\hline SU-8 nível superior & 1590 & 1197 & 1539 \\
\hline SU-8 nível inferior & 2489 & 1744 & 2242 \\
\hline Razão nivel inferior & 1,57 & 1,46 & 1,46 \\
\hline
\end{tabular}

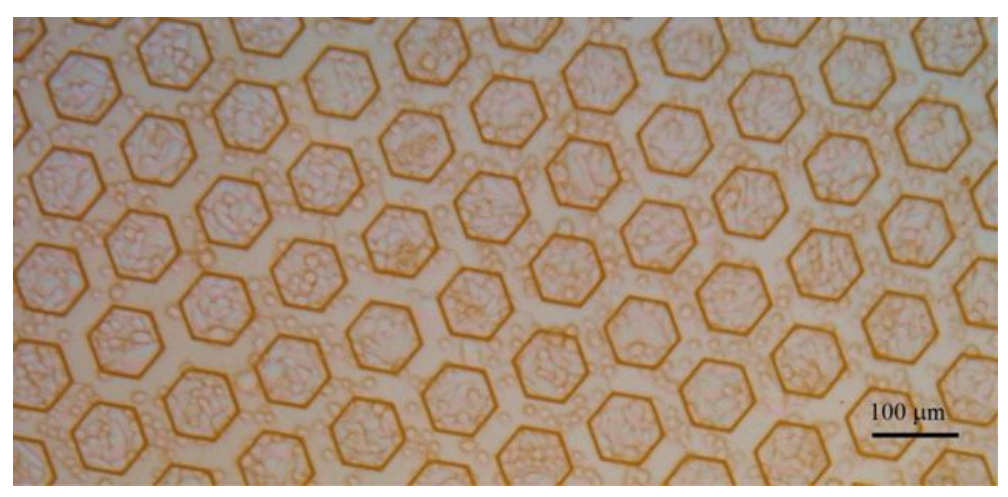

(a)

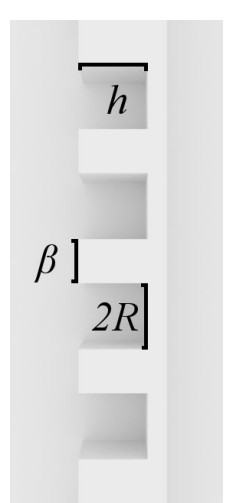

(b)

Figura 3.21: (a) MO de cultura celular realizada em SU-8 litografado, gerando estruturas periódicas na forma de cavidades hexagonais com parâmetros $2 R=82 \mu \mathrm{m}, \beta=37 \mu \mathrm{m}$ e $h=3 \mu \mathrm{m}$. Dessa forma $40 \%$ da superfície da amostra ficou em um nível abaixo do restante dela, sendo o desnível de $3 \mu \mathrm{m}$ (que corresponde ao valor de h). (b) Definição para os parâmetros de produção desta geometria.

Na tabela 3.4 apresentamos a quantidade de células vivas (viáveis) por unidade de área, para três experimentos independentes, para culturas celulares realizadas em amostra microestruturada em SU-8 com geometria periódica e parâmetros definidos de acordo como mostrado na figura $3.21 \mathrm{~b}$. Os valores apresentados foram obtidos a partir das contagens realizadas em 5 imagens de microscopia óptica para cada um dos três experimentos independentes. Na tabela 3.4 temos a última linha sendo a razão entre o número de células vivas por unidade de área do nível inferior pelo superior, gerando um fator adimensional para cada experimento. Os resultados mostram que o valor médio das razões entre o "número de células vivas por unidade de área do nível inferior" pelo "número de células vivas por unidade de área do nível superior" foi de 1,50. Assim, claramente as células apresentam preferência em ocupar as regiões das cavidades (nível inferior), o que é um resultado original. 


\subsubsection{Resultados para a análise de correlação.}

Analisou-se através da função de correlação, como descrito na seção 2.7.4, as micrografias para os núcleos marcados pelo fluoróforo DAPI com intuito de se entender como as células estavam organizadas. Obtivemos a função de correlação para cada uma das superfícies com $2 \mathrm{R}$ de $12 \mu \mathrm{m}, 30 \mu \mathrm{m}, 80 \mu \mathrm{m}, 270 \mu \mathrm{m}, 560 \mu \mathrm{m}$ e SU-8 liso a partir de imagens binarizadas tal como é apresentado na figura 3.22a. Para a função de correlação dada de acordo com a equação 2.20 obteve-se funções tal como é apresentado na figura $3.22 \mathrm{~b}$.

$$
\operatorname{Corr}(\vec{r})=F F T^{-1}\left(\mid\left. F F T(\text { Imagem })\right|^{2}\right) / \rho^{2} N(\vec{r})
$$

onde $F F T^{-1}$ é a transformada inversa de Fourier e $\rho^{2} N(\vec{r})$ é um fator de normalização que leva em conta uma região parcial da imagem.

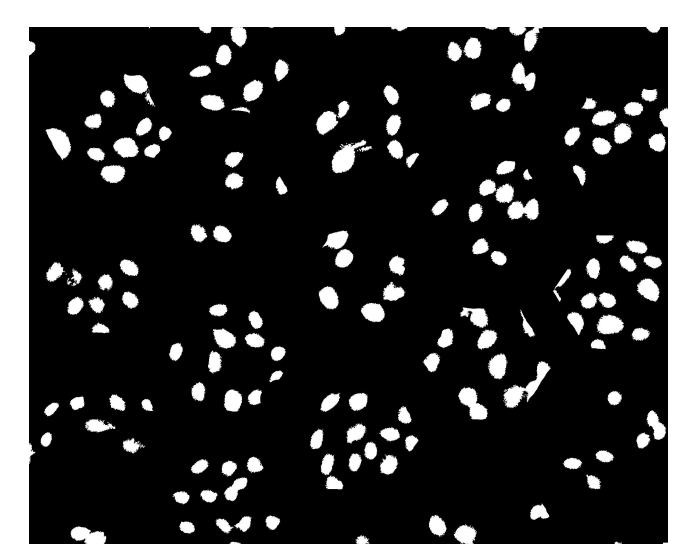

(a)

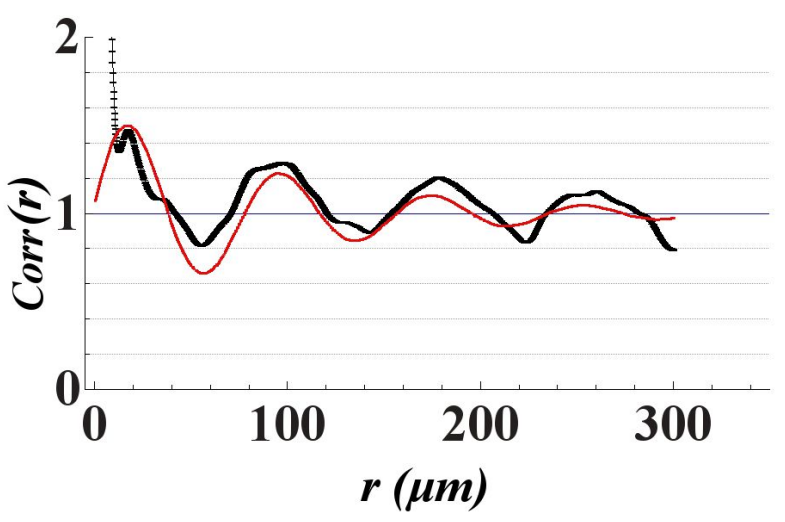

(b)

Figura 3.22: (a) Exemplo de imagem binarizada.(b) Exemplo de curva obtida para $\operatorname{Corr}(r)$ (linha preta) e o respectivo ajuste, segundo equação 2.20 (linha vermelha).

Nas figuras 3.23, 3.24 e 3.25 são apresentadas as distâncias entre os primeiros, segundos e terceiros vizinhos mais próximos, obtidas das regiões dos primeiros, segundos e terceiros picos do gráfico de $\operatorname{Corr}(r)$, respectivamente. Estas distâncias foram obtidas a partir dos gráficos de $\operatorname{Corr}(r)$ para cada tipo de superfície. As superfícies dos substratos HEX-80 possuem os menores valores de distâncias para primeiros e segundos vizinhos, ou seja, as células estão mais próximas umas das outras. As demais superfícies tendem a separar mais as células, isto é, nessas superfícies as células apresentam os valores mais elevados medidos para as distâncias entre seus vizinhos.

Na tabela 3.5 são apresentados os valores obtidos para o ajuste da função de correlação, segundo a equação 2.20: $\operatorname{Cor}(r)=1+A \cdot \exp \left(-r / d_{c}\right) \cos \left(\pi r / r_{c}\right)$ tal como realizado por Gomp- 
per e colaboradores [169], onde, A é uma constante, $d_{c}$ é a distância entre aglomerados e $r_{c}$ é o raio dos aglomerados. Na tabela 3.5 vemos que o SU-8 liso e HEX-80 são iguais, dentro das incertezas, e apresentam os menores valores para o raio de aglomerado $\left(r_{c}\right)$ e a distância entre aglomerados $\left(d_{c}\right)$. Além disso, quando olhamos para o número de primeiros vizinhos $\left(N_{p}\right)$ (veja apêndice D) vemos que o substrato HEX-80 apresenta um valor maior, $N_{p}=15$, quando comparado ao SU-8 liso, que possui apenas $N_{p}=10$. Assim, podemos concluir que a densidade de células por unidade de área é maior para o substrato HEX-80, resultado coerente com o apresentado anteriormente. As superfícies HEX-12 e HEX-30 são as que possuem maior valor para o raio de aglomerado $51,6 \pm 0,4 \mu \mathrm{m}$ e $50,8 \pm 1,8 \mu \mathrm{m}$, respectivamente e também para a distância entre aglomerados. Estes valores mostram que de fato estas superfícies dificultam o crescimento celular, promovendo uma maior separação entre as células, sem que haja um impacto no número de primeiros vizinhos quando comparado ao SU-8 liso. Para as estruturas HEX-280 e Hex-560 os valores de $N_{p}$ (10 e 9, respectivamente) são similares ao do SU-8 liso $\left(N_{p}=10\right)$. No entanto, os valores de raio de aglomerado $\left(r_{c}\right)$ e a distância entre aglomerados $\left(d_{c}\right)$, são maiores para HEX-280 e Hex-560, quando comparado ao SU-8 liso, chegando a 44\% e $46 \%$ a mais, respectivamente, para os valores de $d_{c}$. Assim, podemos concluir que, quando o tamanho das cavidades é muito maior que o tamanho das células, estas tendem a separar os aglomerados, mas mantendo o número de primeiros vizinhos, quando comparado ao SU-8 liso.

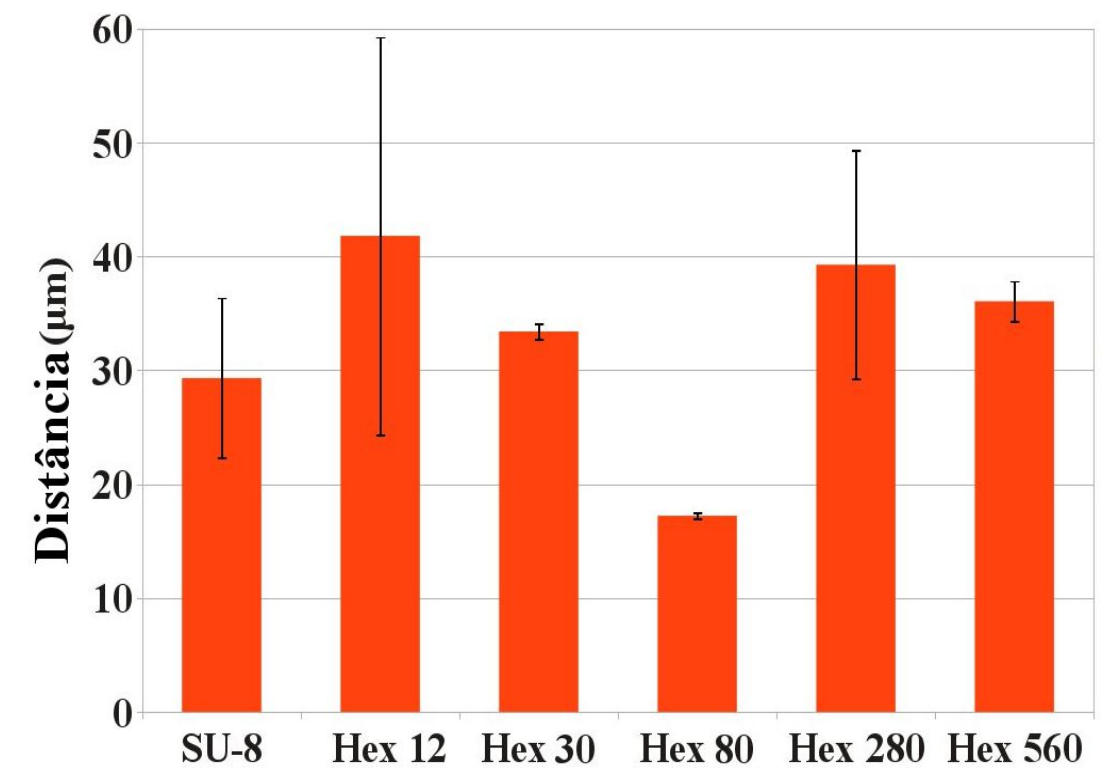

Figura 3.23: Histograma para as distâncias entre os primeiros vizinhos. 


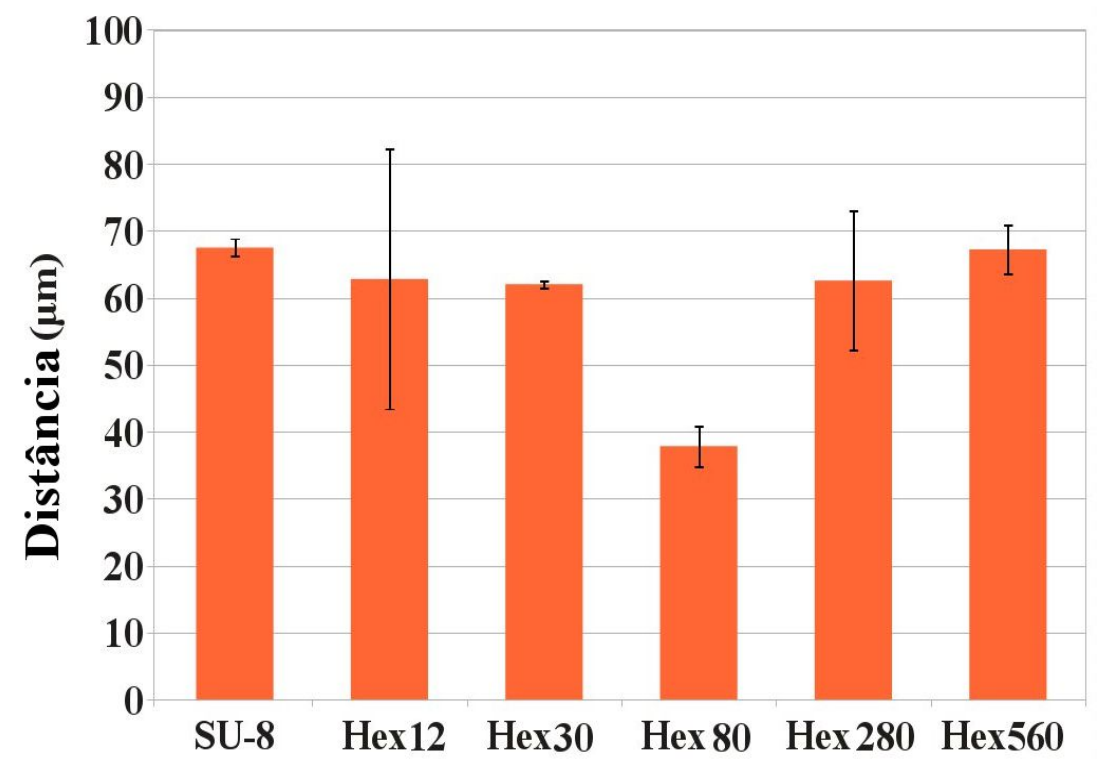

Figura 3.24: Histograma para as distâncias entre os segundos vizinhos mais próximos.

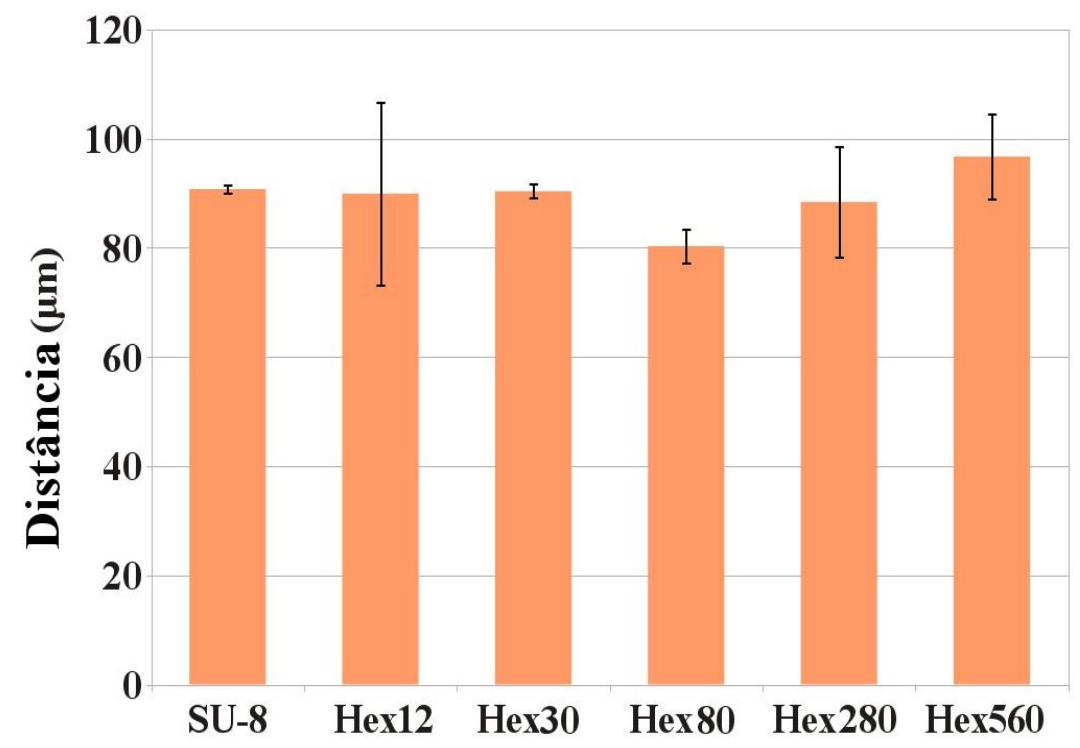

Figura 3.25: Histograma para as distâncias entre os terceiros vizinhos mais próximos.

A análise de correlação mostrou com clareza o que não era evidenciado apenas visualizandose as imagens. Ela mostra que as células, mesmo em SU-8 liso tem a forte tendência de formar aglomerados de células no raio de $\sim 45 \mu \mathrm{m}$. Dessa forma fica explicado o porque das cavidades de $40 \mu \mathrm{m}$ de raio favorecerem o melhor desempenho da cultura nessas superfícies. O melhor desempenho da cultura celular no substrato HEX-80, quando comparado ao SU-8 liso, pode ser justificado pelo proposto por Thery [101] em que cultura de células em superfície contendo 
Tabela 3.5: Parâmetros obtidos para o ajuste da função de correlação para os diversos tipos de superfícies litografadas.

\begin{tabular}{|c|c|c|c|}
\hline Amostra & Raio do Aglomerado $\left(r_{c}\right)$ & Distancia entre Aglomerados $\left(d_{c}\right)$ \\
\hline SU-8 liso & $44,2 \pm 1,5 \mu \mathrm{m}$ & \multicolumn{2}{|c|}{$102,9 \pm 1,3 \mu \mathrm{m}$} \\
\hline HEX-12 & $51,6 \pm 0,4 \mu \mathrm{m}$ & \multicolumn{2}{|c|}{$210,4 \pm 8,1 \mu \mathrm{m}$} \\
\hline HEX-30 & $50,8 \pm 1,8 \mu \mathrm{m}$ & \multicolumn{2}{|c|}{$213,7 \pm 1,4 \mu \mathrm{m}$} \\
\hline HEX-80 & $45,8 \pm 0,3 \mu \mathrm{m}$ & \multicolumn{2}{|c|}{$105,7 \pm 2,4 \mu \mathrm{m}$} \\
\hline HEX-280 & $49,4 \pm 1,0 \mu \mathrm{m}$ & \multicolumn{2}{|c|}{$148,4 \pm 9,5 \mu \mathrm{m}$} \\
\hline HEX-560 & $49,4 \pm 1,7 \mu \mathrm{m}$ & \multicolumn{2}{|c|}{$150,8 \pm 9,3 \mu \mathrm{m}$} \\
\hline \hline Amostra & $\begin{array}{c}\text { Número de primeiros } \\
\text { vizinhos }\left(N_{p}\right)\end{array}$ & Erro no ajuste & $\chi^{2}$ reduzido \\
& 10 & 0,01 & 0,01 \\
\hline SU-8 liso & 11 & 0,05 & 0,05 \\
\hline HEX-12 & 9 & 0,04 & 0,03 \\
\hline HEX-30 & 15 & 0,01 & 0,01 \\
\hline HEX-80 & 10 & 0,03 & 0,02 \\
\hline HEX-280 & 9 & & \\
\hline HEX-560 & & & \\
\hline
\end{tabular}

padrões são mais semelhantes as condições fisiológicas encontradas em um tecido por exemplo, fazendo que as células estejam numa situação mais confortável.

Thery argumenta que sob condições clássicas de cultura in vitro o conjunto de informações espaciais, mecânicas e químicas são perdidas pois a única informação que as células acabam checando é se a superfície, geralmente plana, de um material polimérico ou de vidro é adequada para sua adesão [101]. Deste modo, a microfabricação de padrões modificam o microambiente da cultura de células e restaura algumas das informações que as células devem checar. Pode-se enumerar estas informações tais como: (1) espaciais, que estão relacionadas com geometria do substrato e do tecido que será formado, (2) informações químicas, que estão relacionadas com a adesão celular e (3) informações mecânicas, que estão relacionadas com a rigidez do substrato. Este conjunto de informações faz com que a condição de cultura de células em superfície contendo padrões mais se assemelhem as condições fisiológicas encontradas por exemplo, em um tecido [101]. 
$\Gamma_{\text {Capítulo }}$

\section{Sumário e Conclusão}

Superfícies de vidro, SU-8, PDMS e DLC lisas e isentas de modificação ou tratamento específico foram avaliadas quanto ao cultivo celular, utilizando células $\mathrm{CHO}$. Valores médios dos fatores de forma $\left(F_{f}\right)$ de 450 células, para cada uma das culturas realizadas sobre vidro, SU8, DLC e PDMS foram calculados gerando valores próximos a 0,52 para o vidro, o SU-8 liso e o DLC, demonstrando um bom espraiamento das células nessas superfícies. Para a superfície de PDMS foi obtido o valor unitário para o fator de forma $\left(F_{f}\right)$, que está relacionado a um baixo espraiamento das células. Assim, podemos concluir que, dos quatro materiais avaliados, o PDMS foi o único que se mostrou com pobre adesão, dificultando o cultivo das células.

A energia de superfície $(E S)$ foi medida para todos os substratos e os resultados obtido de $E S$ para o PDMS é compatível com o resultado de fator de forma $\left(F_{f}\right)$, uma vez que se obtêm o pior valor para ES confirmando a baixa adesão celular, o que promove a geração de células com elevado fator de forma $\left(F_{f}\right)$. A ES do DLC e SU-8 têm valores intermediários em comparação com PDMS e vidro, no entanto DLC e SU-8 apresentam fator de forma baixo, indicando boa adesão celular. Curiosamente, apesar da diferença significativa entre ES do SU-8, DLC e vidro, a diferença entre os fatores de forma não foram tão significativos.

Na sequência do trabalho, foram realizadas modificações de superfícies por tratamento por plasma e implantação iônica e novas culturas celulares foram efetuadas. O SU-8 com superfície lisa foi utilizado como substrato para implantação iônica de prata. A dose utilizada foi de $1,2 \times 10^{16}$ átomos $/ \mathrm{cm}^{2}$ e a energia de implantação foi de $8 \mathrm{keV}$. Através da análise de RBS foi possível determinar a dose de implantação de prata $(A g)$ em SU-8. A dose medida foi de $1,2 \times$ $10^{16}$ átomos $/ \mathrm{cm}^{2}$. Conforme os valores de percentuais atômico obtido pela análise observou-se que há 2 átomos de Ag para cada átomo de oxigênio e supondo-se que todo oxigênio presente esteja ligado aos átomos de prata podemos esperar que o material implantado seja óxido de 
prata $\left(\mathrm{Ag}_{2} \mathrm{O}\right)$. Através do código TRIDYN obteve-se o perfil de implantação em profundidade da fração de átomos de prata para a implantação de uma dose de $1,2 \times 10^{16}$ átomos $/ \mathrm{cm}^{2}$ com energia de $8 \mathrm{keV}$ em superfície de SU-8. Pelo perfil apresentado, o máximo de fração de átomos de prata se encontra à cerca de $12 \mathrm{~nm}$ da superfície do SU-8.

Culturas celulares foram realizadas em SU-8 com superfície lisa onde foi implantada uma dose de $1,2 \times 10^{16}$ átomos $/ \mathrm{cm}^{2}$ de prata com uma energia de $8 \mathrm{keV}$. Como referência foi utilizada uma superfície lisa de SU-8, sem implantação. Os resultados mostraram que o número de células vivas por unidade de área foi superior na superfície de SU-8 com prata implantada, mostrando o bom desempenho da cultura nesse substrato. Observamos ainda que o número de células mortas por unidade de área foi superior na superfície de SU-8 com prata implantada, mas considerando que esse número é inferior a $1 \%$ das células vivas por unidade de área, ainda assim, a implantação de prata em SU-8 se mostrou com melhor desempenho para a cultura celular. Foram realizadas análises complementares para tentarmos justificar os resultados. Assim, a energia livre de superfície do SU-8 foi determinada a partir de medições do ângulo de contato para o SU-8 $(35 \pm 1 \mathrm{mN} / \mathrm{m})$ e para o SU-8/Ag $(30 \pm 1 \mathrm{mN} / \mathrm{m})$. A diferença entre os valores é demasiadamente baixa para justificar uma diferença de comportamento das células em suas superfícies. Foi possível observar por AFM que a superfície do SU-8 após a implantação estava nanoestruturada apresentando rugosidade de $R q=1,1 \mathrm{~nm}$ enquanto que a rugosidade do SU-8 original era de $R q=0,5 \mathrm{~nm}$. Sabe-se, no entanto, que as superfícies nanoestruturadas pode interferir com o crescimento de células apenas quando as estruturas têm razão de aspecto próximo da unidade [171], o que não ocorre. O tamanho lateral das estruturas foram em média de $40 \mathrm{~nm}$, e as alturas foram $5 \mathrm{~nm}$, dando uma razão de aspecto de 0,13 . No que diz respeito à área de superfície, o SU-8/Ag tem uma área de 6,7\% mais elevada do que o original SU-8, que é compatível com a baixa razão de aspecto das estruturas. Desta forma, estas nanoestruturas não devem justificar também o comportamento diferente de células na superfície SU-8/Ag. É conhecido que mediante implantação iônica de um metal em polímero, excedendo o limite de solubilidade da matriz polimérica, nanopartículas do metal nucleiam e crescem com o aumento da dose implantada [172]. Assim, os resultados aqui obtidos possivelmente podem ser justificados pela formação de nanopartículas de óxido de prata logo abaixo da superfície de SU-8, mais precisamente a cerca de $12 \mathrm{~nm}$, como obtido na simulação por TRIDYN. Assim, uma possível razão para o melhor desempenho para o crescimento celular em SU-8/Ag é a possibilidade das nanopartículas de prata exercerem algum tipo de interação com as células. Nós sugerimos que provavelmente seja potencial de superfície.

Superfícies de DLC tratadas com plasma de oxigênio (DLC-O) e com plasma de hexafluoreto de enxofre (DLC-F) foram utilizadas para cultura celular. Como referência foi utilizada 
uma superfície de DLC sem tratamento em plasma. Os resultados mostraram que o número de células vivas por unidade de área foi superior para a superfície tratada com plasma de oxigênio (DLC-O), quando comparado com a superfície tratada com plasma de hexafluoreto de enxofre (DLC-F). Quanto à superfície de referência (DLC sem tratamento em plasma), notamos comportamentos não reprodutível, possivelmente devido a aleatoriedade de espécies químicas presentes na superfície do DLC sem tratamento. As superfícies DLC-F, DLC-O e DLC sem tratamento com plasma foram também analisadas através de microscopia de fluorescência, utilizando o marcador DAPI. Os resultados de três experimentos independentes de contagem de número de núcleos (marcados com DAPI) por unidade de área confirmaram os resultados obtidos através do teste de viabilidade com o uso de trypan blue. Novamente, a superfície tratada com plasma de oxigênio (DLC-O), apresentou um maior número de núcleos por unidade de área, quando comparado à superfície tratada com pasma de hexafluoreto de enxofre (DLC-F). Da mesma forma que nos resultados obtidos pelo teste de viabilidade, a superfície de DLC sem tratamento com plasma apresentou resultados aleatórios na contagem de núcleos por unidade de área. Dos valores das energias de superfície para as amostras de DLC-F, DLC-O e DLC sem tratamento com plasma os resultados indicaram que a superfície DLC-O é mais hidrofílica do que a superfície DLC-F, confirmando resultados já publicados pelo grupo [4-7]. É conhecido da literatura [170] que superfícies hidrofílicas apresentam melhor desempenho em cultura celular, o que é coerente com os resultados obtidos em nosso trabalho, onde a superfície DLC-O apresenta maior número de núcleos e maior número de células vivas por unidade de área, quando comparada à superfície DLC-F.

Cultura de células CHO foram realizadas em superfícies litografadas HEX-12, HEX-30, HEX-80, HEX-280, HEX-560 e SU-8 liso. O parâmetro $h$ foi mantido constante e dado por $h=3 \mu \mathrm{m} \operatorname{com} \beta$ variando entre 1,5 e 9. Estas superfícies foram caracterizadas por microscopia óptica de fluorescência onde os núcleos foram marcados com o fluoróforo DAPI. Caracterizamos estas superfícies com relação ao número de núcleos por unidade de área, isto é, núcleos $/ \mathrm{mm}^{2}$. Obteve-se histogramas com o número médio de núcleos por $\mathrm{mm}^{2} \mathrm{em}$ três experimentos independentes para as superfícies litografadas HEX-12, HEX-30, HEX-80, HEX-280, HEX-560 e SU-8 liso. Esses resultados mostram que o número de núcleos por unidade de área foi consideravelmente maior para HEX-80. O tamanho médio das células $\mathrm{CHO}$ quando estavam espraiadas era entre 40 e $75 \mu \mathrm{m}$. Assim, o argumento para uma menor proliferação das células nas superfícies contendo cavidades periódicas de HEX-12 e HEX-30 pode ser justificado pela dificuldade das células $\mathrm{CHO}$ aderirem na superfície, desde que uma célula espraiada ocuparia diversas estruturas do substrato. Para as superfícies contendo cavidades periódicas de HEX-80, HEX-280 e HEX-560 observamos pelas imagens obtidas que os núcleos ocupavam preferenci- 
almente áreas interiores às cavidades. Este fato sugere não haver dificuldade na adesão devido às microestruturas. No entanto, há um excelente desempenho da cultura celular para a dimensão de cavidade de HEX-80, quando comparado ao desempenho da cultura em superfícies contendo cavidades periódicas de HEX-280 e HEX-560.

Em uma outra etapa realizou-se culturas celulares em triplicata dos substratos com as superfícies de HEX-12, HEX-80, HEX-280, HEX-560 e SU-8 liso. As células em cada uma das superfícies foram analisadas por microscopia óptica (MO) para avaliação da viabilidade celular, utilizando marcador trypan blue. Obteve-se histogramas com os valores médios para três experimentos independentes para o número de células vivas $/ \mathrm{mm}^{2}$ para as culturas celulares realizadas nestas superfícies. O histograma da cultura celular utilizando marcação com trypan blue, corrobora os resultados apresentados com o histograma da cultura celular que tiveram os núcleos marcados pelo fluoróforo DAPI. Assim, fica confirmado o melhor desempenho da cultura celular no substrato HEX-80 que apresentou o maior número de células vivas $/ \mathrm{mm}^{2}$. Nestas superfícies obtivemos imagens de Microscopia Óptica das células nas superfícies dos substratos em estudo, diferentemente das imagens de Microscopia óptica de fluorescência que apresenta imagens dos núcleos dessas células. Assim, foi possível extrair das imagens como as células se acomodam nas estruturas hexagonais litografadas. No substrato HEX-12 as células se apresentam prioritariamente esféricas e aderidas, muitas vezes, em uma única estrutura hexagonal, comprovando a baixa adesão. Nos demais substratos SU-8 liso, HEX-80, HEX-280 e HEX-560 as células se apresentavam majoritariamente espraiadas, mas claramente a maior proliferação se deu no caso do substrato HEX-80.

Um último substrato utilizado para culturas celulares consistiu em SU-8 litografado com o objetivo de avaliar a presença de degraus na superfície. A geometria também foi periódica na forma de cavidades hexagonais, mas com parâmetros $2 R=82 \mu \mathrm{m}, \beta=37 \mu \mathrm{m}$ e $h=3 \mu \mathrm{m}$. Dessa forma parte da superfície da amostra ficou em um nível abaixo do restante dela, sendo o desnível de $3 \mu \mathrm{m}$. Os resultados mostram que o valor médio das razões entre o "número de células vivas por unidade de área do nível inferior" pelo "número de células vivas por unidade de área do nível superior" foi de 1,50. Assim, claramente as células apresentam preferência em ocupar as regiões das cavidades (nível inferior), o que é um resultado original.

Analisou-se através da função de correlação as micrografias para os núcleos marcados pelo fluoróforo DAPI com intuito de se entender como as células estavam organizadas. Obteve-se da função de correlação para cada uma das superfícies litografadas HEX-12, HEX-30, HEX-80, HEX-280, HEX-560 e SU-8 liso as distâncias entre os primeiros, segundos e terceiros vizinhos mais próximos, obtidas das regiões dos primeiros, segundos e terceiros picos do gráfico de 
$\operatorname{Corr}(\vec{r})$, respectivamente. Estas distâncias foram obtidas a partir dos gráficos de $\operatorname{Corr}(\vec{r})$ para cada tipo de superfície. As superfícies dos substratos HEX-80 possuem os menores valores de distâncias para primeiros e segundos vizinhos, ou seja, as células estão mais próximas umas das outras. As demais superfícies tendem a separar mais as células, isto é, nessas superfícies as células apresentam os valores mais elevados medidos para as distâncias entre seus vizinhos.

Obteve-se também os valores obtidos para o ajuste da função de correlação, segundo a equação 2.20: $\operatorname{Cor}(r)=1+A \cdot \exp \left(-r / d_{c}\right) \cos \left(\pi r / r_{c}\right)$ tal como realizado por Gompper e colaboradores [169]. Destes resultados, vemos que o SU-8 liso e HEX-80 são iguais, dentro das incertezas, e apresentam os menores valores para o raio de aglomerado $\left(r_{c}\right)$ e a os aglomerados $\left(d_{c}\right)$. Além disso, quando olhamos para o número de primeiros vizinhos $\left(N_{p}\right)$ vemos que o substrato HEX-80 apresenta um valor maior, $N_{p}=15$, quando comparado ao SU-8 liso, que possui apenas $N_{p}=10$. Assim, podemos concluir que a densidade de células por unidade de área é maior para o substrato HEX-80, resultado coerente com o apresentado anteriormente. As superfícies HEX-12 e HEX-30 são as que possuem maior valor para o raio de aglomerado $51,6 \pm 0,4 \mu \mathrm{m}$ e $50,8 \pm 1,8 \mu \mathrm{m}$, respectivamente e também para a distância entre aglomerados. Estes valores mostram que de fato estas superfícies dificultam o crescimento celular, promovendo uma maior separação entre as células, sem que haja um impacto no número de primeiros vizinhos quando comparado ao SU-8 liso. Para as estruturas HEX-280 e Hex-560 os valores de $N_{p}$ (10 e 9 , respectivamente) são similares ao do SU-8 liso $\left(N_{p}=10\right)$. No entanto, os valores de raio de aglomerado $\left(r_{c}\right)$ e de distância entre aglomerados $\left(d_{c}\right)$, são maiores para HEX-280 e Hex-560, quando comparado ao SU-8 liso, chegando a $44 \%$ e $46 \%$ a mais, respectivamente, para os valores de $d_{c}$. Assim, podemos concluir que, quando o tamanho das cavidades é muito maior que o tamanho das células, estas tendem a separar os aglomerados, mas mantendo o número de primeiros vizinhos, quando comparado ao SU-8 liso.

A análise de correlação mostrou com clareza o que não era evidenciado apenas visualizandose as imagens. Ela mostra que as células, mesmo em SU-8 liso tem a forte tendência de formar aglomerados de células no raio de $\sim 45 \mu \mathrm{m}$. Dessa forma fica explicado o porque das cavidades de $40 \mu \mathrm{m}$ de raio favorecerem o melhor desempenho da cultura nessas superfícies. O melhor desempenho da cultura celular no substrato HEX-80, quando comparado ao SU-8 liso, pode ser justificado pelo proposto por Thery [101] em que cultura de células em superfície contendo padrões são mais semelhantes as condições fisiológicas encontradas em um tecido por exemplo, fazendo que as células estejam numa situação mais confortável. 


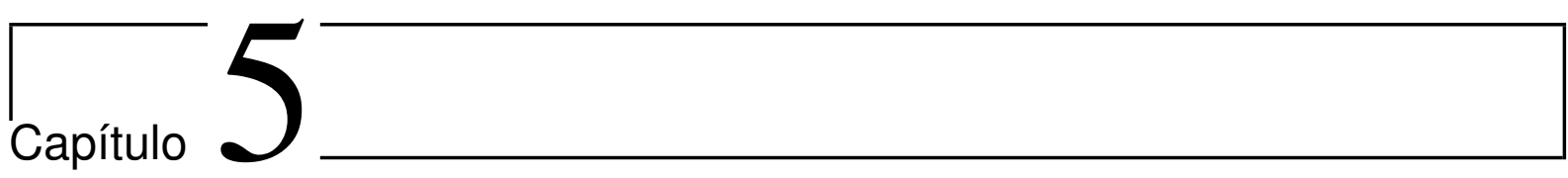

\section{Perspectivas de trabalhos futuros.}

O estudo utilizando a implantação de íons de prata em substrato, quanto a adesão e o crescimento celular, deve ser avaliado em outras superfícies como: vidro (como material de controle), SU-8 (foto-resiste epóxi, para reanálise), PDMS (silicone ou Poli(dimetil siloxano)) e DLC (diamond-like carbon livre de hidrogênio). A prata que será utilizada na implantação iônica é de grande interesse por ser bactericida, o que ainda permanecem um mistério para a ciência. É sabido da literatura que a implantação de metal no polímero causa a formação nanopartículas no interior dos substratos, em região próxima à superfície, o que precisa ser confirmado no caso específico desses substratos para uso em culturas celulares.

O estudo de superfícies microfabricadas variando-se a razão de aspecto $(h / 2 R)$, especificamente o valor do parâmetro $h$ (altura), seria de grande importância para melhor entendimento do trabalho aqui apresentado. As culturas celulares podem ser avaliadas pela contagem de células vivas $/ \mathrm{mm}^{2}$ e pelo número de núcleos $/ \mathrm{mm}^{2}$, similarmente ao aqui apresentado. Outro aspecto interessante consiste em microfabricar outros materiais para avaliação da formação de aglomerados em culturas celulares, com intuito de verificar se os resultados que foram obtidos em SU-8 microfabricado são mantidos. Finalmente, é de interesse utilizar outros tipos células em SU-8 microfabricado nas mesmas dimensões que foram usadas neste trabalho e, através da função de correlação, determinar se há formação de aglomerados. Em caso positivo a determinação dos parâmetros: raio de aglomerado, distância entre aglomerados e número de primeiros vizinhos, poderá permitir o estabelecimento de padrões para uma modelagem futura. 
$\prod_{\text {Apêndice }}$

\section{Resultados de calibração para produção de microcavidades em SU-8 2005.}

Neste apêndice apresentamos em detalhes o procedimento para calibração na litografia por feixe de elétrons para se obter microcavidades hexagonais com o parâmetro $2 R=12 \mu \mathrm{m}$. A corrente do feixe de elétrons no MEV foi variada nos valores de 12, 15 e 20 pA e, para cada valor de corrente, variou-se a dose de exposição do polímero ao feixe de elétrons de 0,05; 0,07; 0,09; 0,11 e $0,13 \mathrm{nC} / \mathrm{cm}$. Litografias utilizando corrente de feixe de $12 \mathrm{pA}$ não geraram estruturas, o que significa que é necessário a utilização de correntes mais altas. As figuras A.2 e A.4 apresentam micrografias MEV das superfícies litografadas para produção de microcavidades hexagonais com diâmetro $2 R=12 \mu \mathrm{m}$, onde utilizamos correntes de feixe de 15 e $20 \mathrm{pA}$. Através dessas micrografias foi possível observar que, para a corrente de 15 pA e dose de $0,05 \mathrm{nC} / \mathrm{cm}$ (veja figura figura A.1a), as microcavidades apresentavam paredes melhor definidas quando comparado as demais. Numa visão mais panorâmica também foi possível observar a menor presença de defeitos de fabricação, sendo esse um fator importante. 


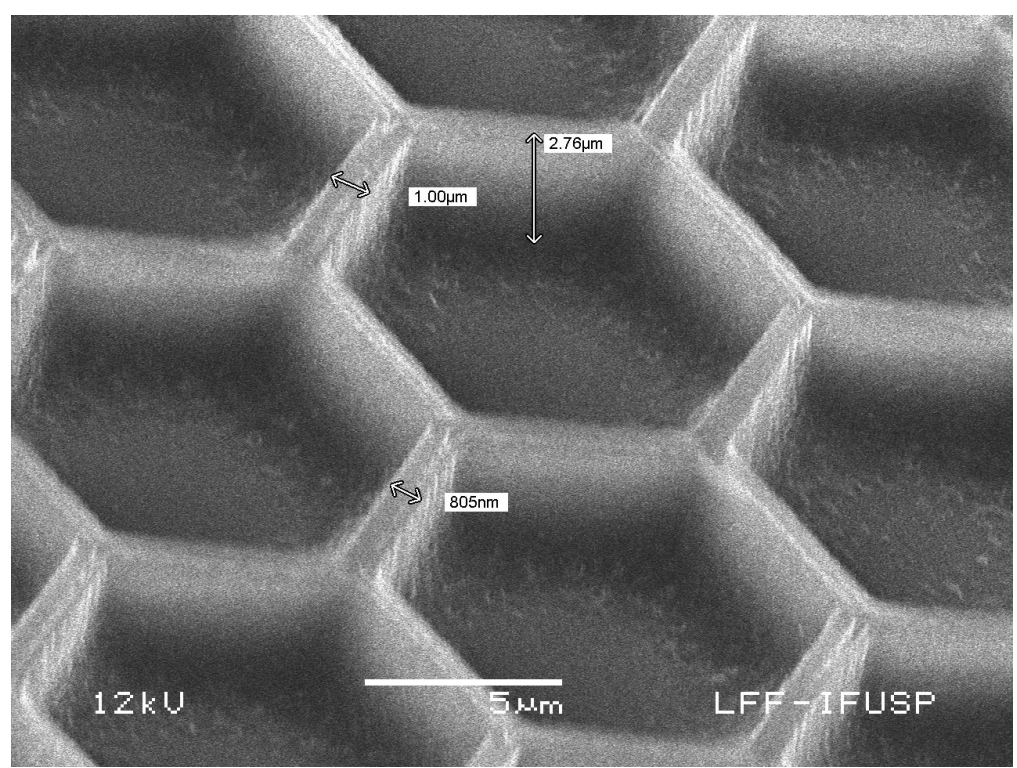

(a) Dose de $0,05 \mathrm{nC} / \mathrm{cm}$.

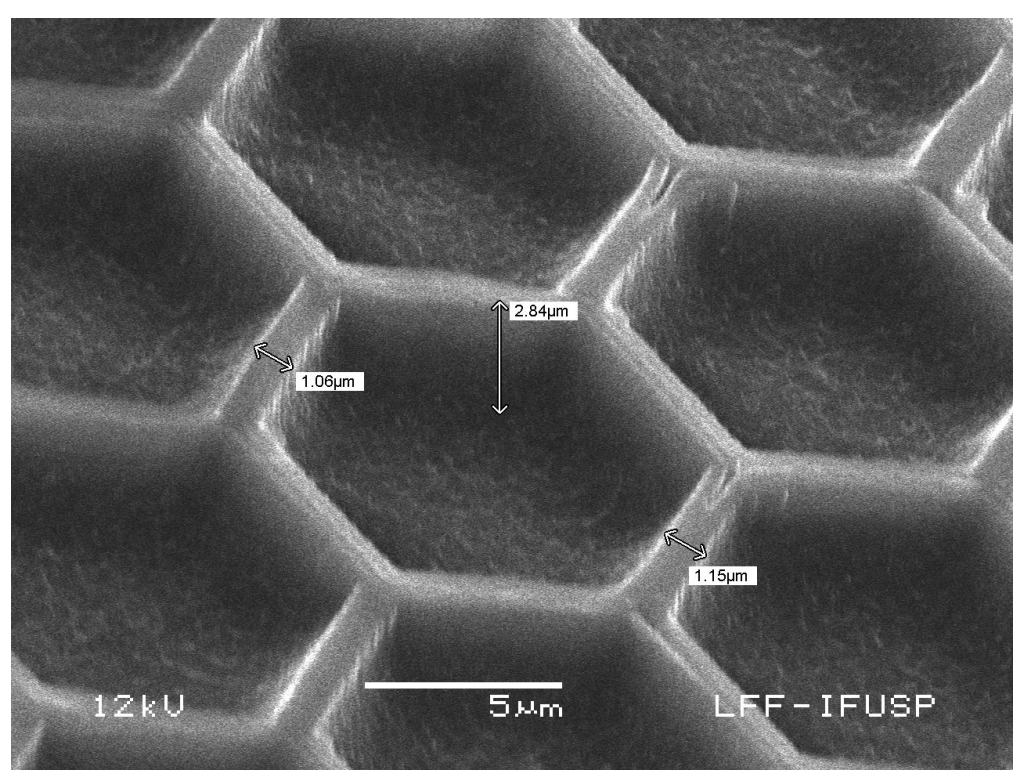

(b) Dose de $0,07 \mathrm{nC} / \mathrm{cm}$.

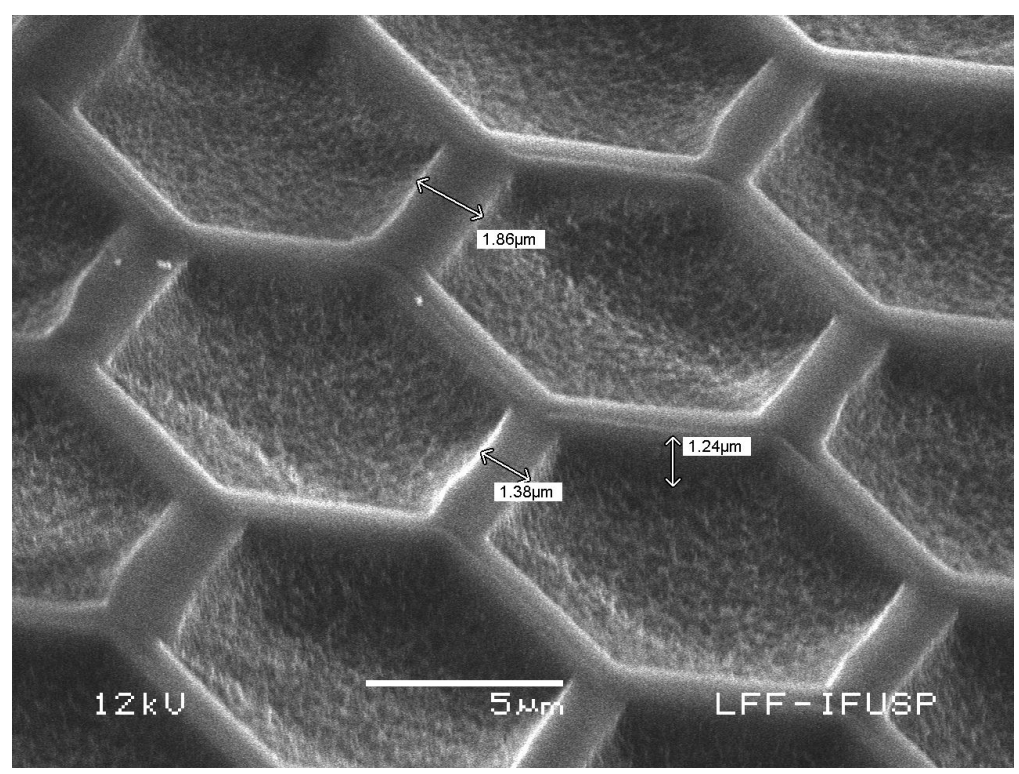

(c) Dose de 0,09 $\mathrm{nC} / \mathrm{cm}$. 


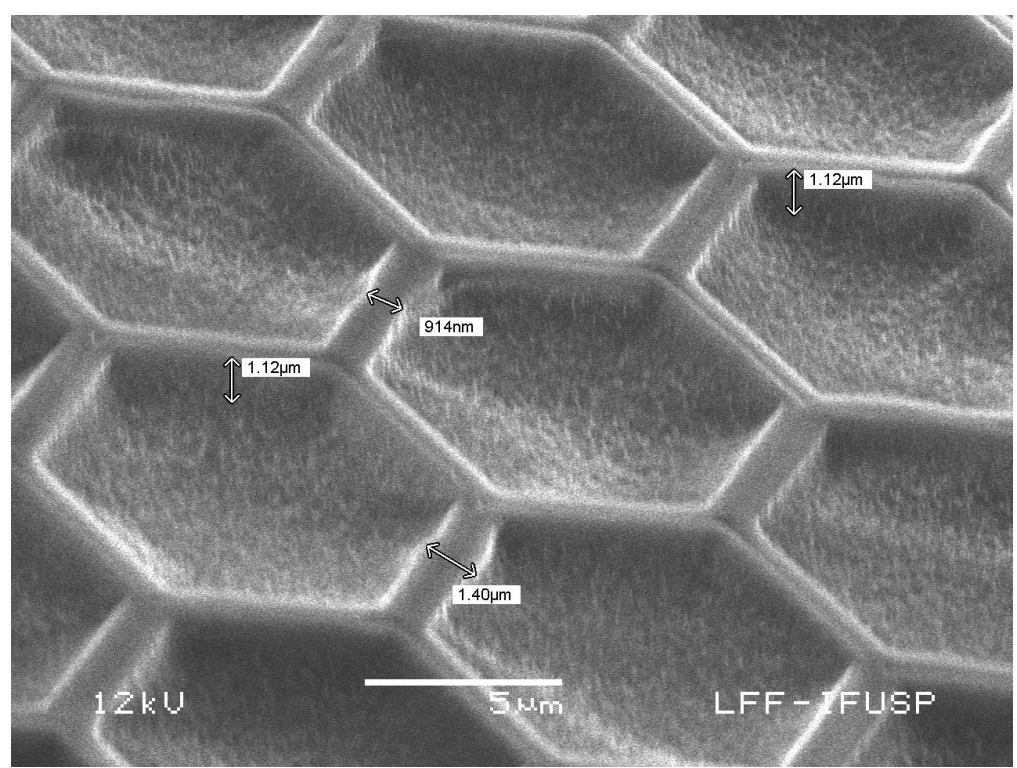

(d) Dose de $0,11 \mathrm{nC} / \mathrm{cm}$.

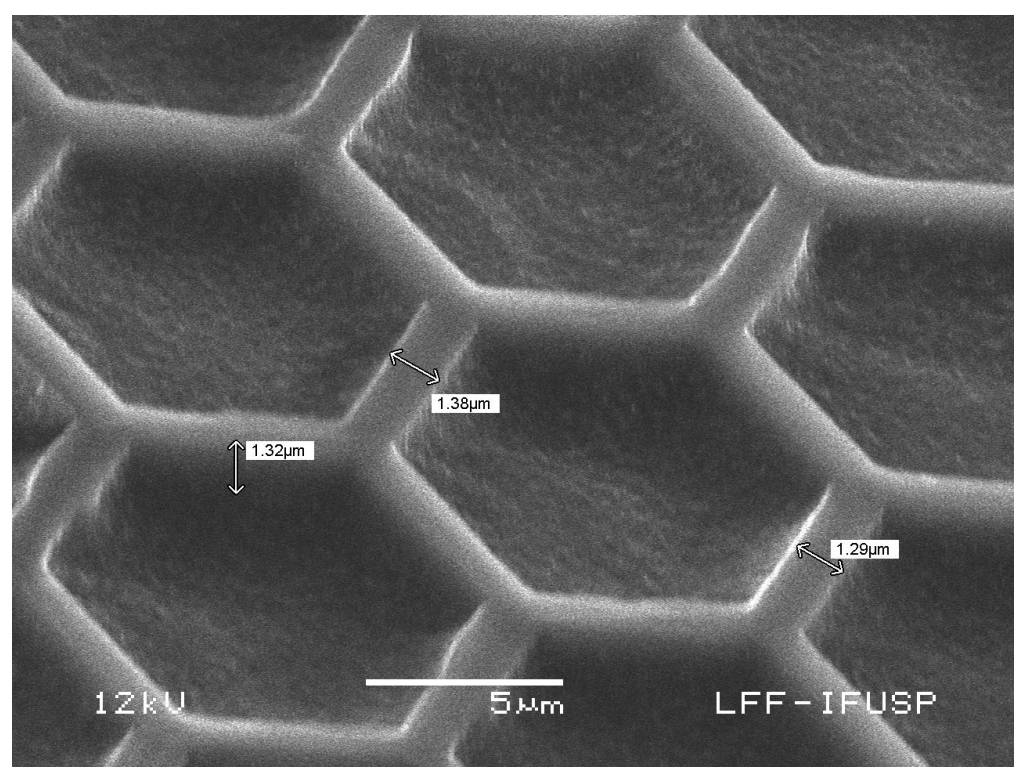

(e) Dose de $0,13 \mathrm{nC} / \mathrm{cm}$.

Figura A.2: Micrografias MEV de superfícies obtidas para corrente do feixe de elétrons de 15 pA com variação na dose, utilizada na litografia de cavidades hexagonais com $2 R=12 \mu \mathrm{m}$. 


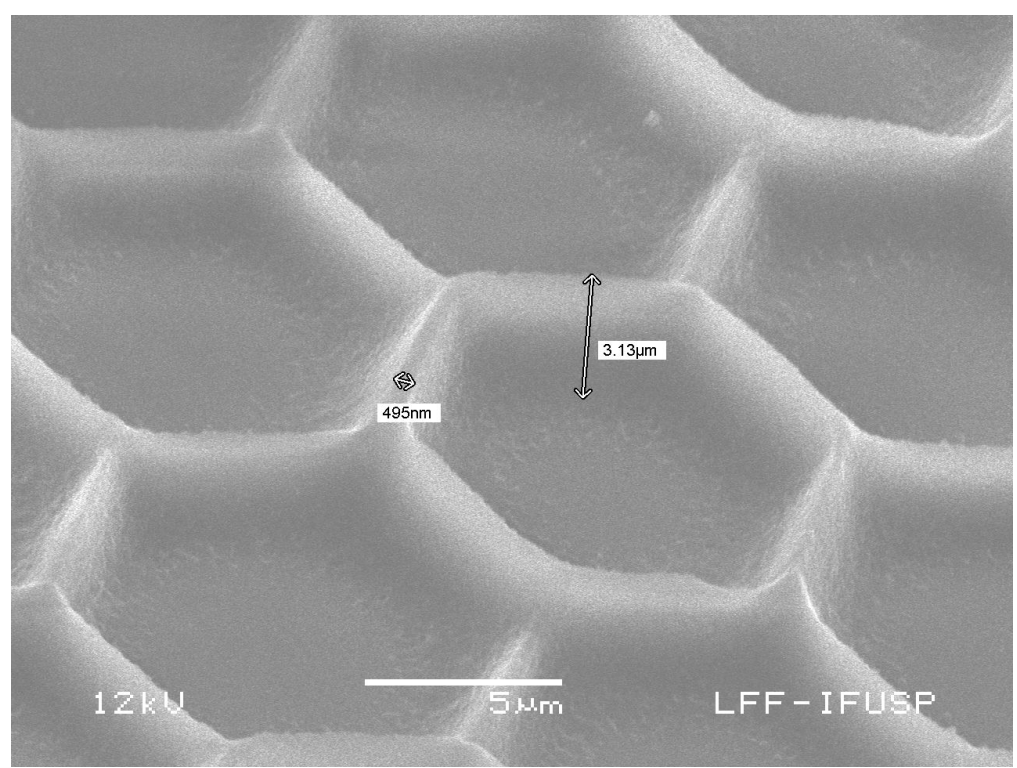

(a) Dose de $0,05 \mathrm{nC} / \mathrm{cm}$.

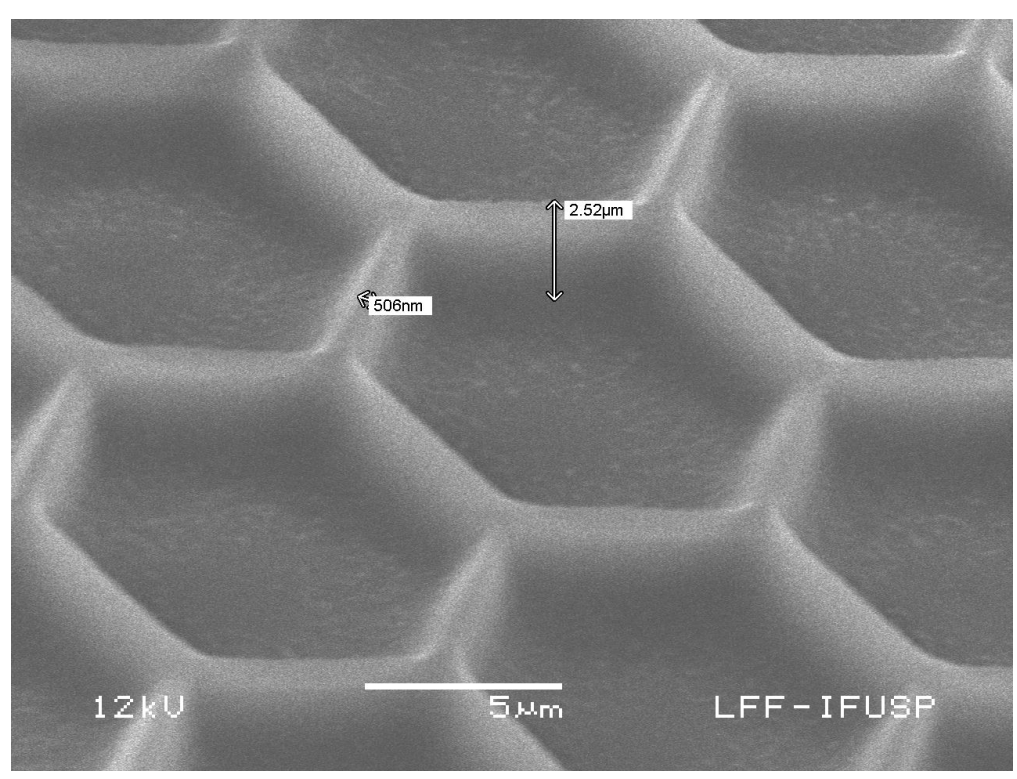

(b) Dose de $0,07 \mathrm{nC} / \mathrm{cm}$.

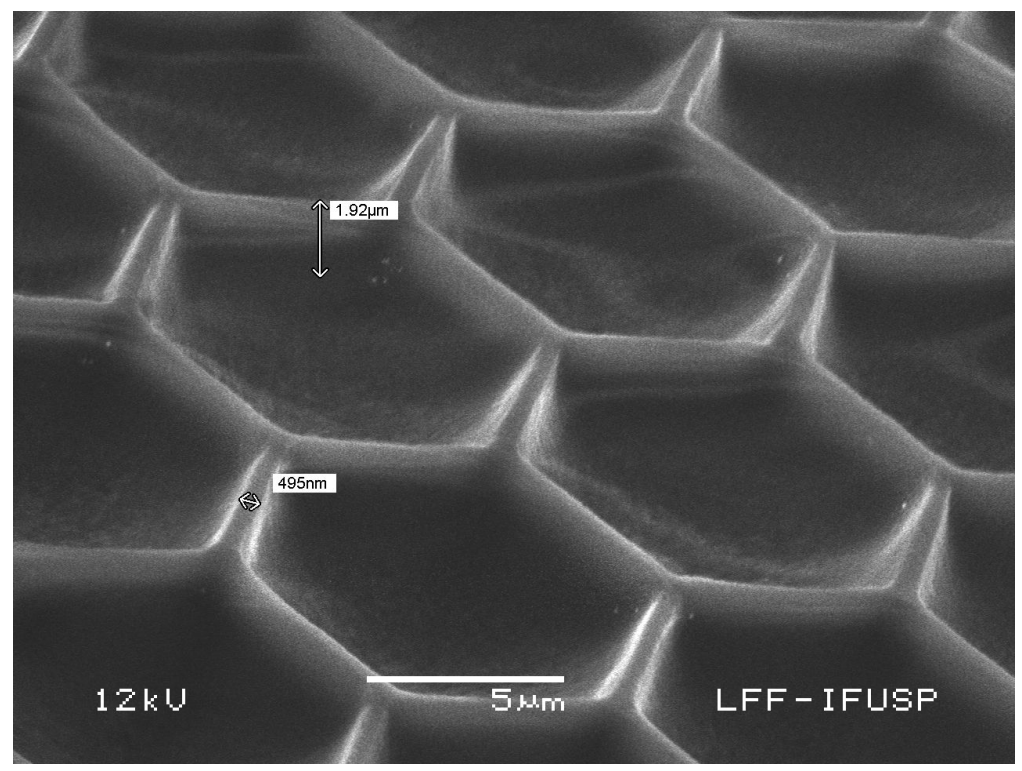

(c) Dose de 0,09 nC/cm. 


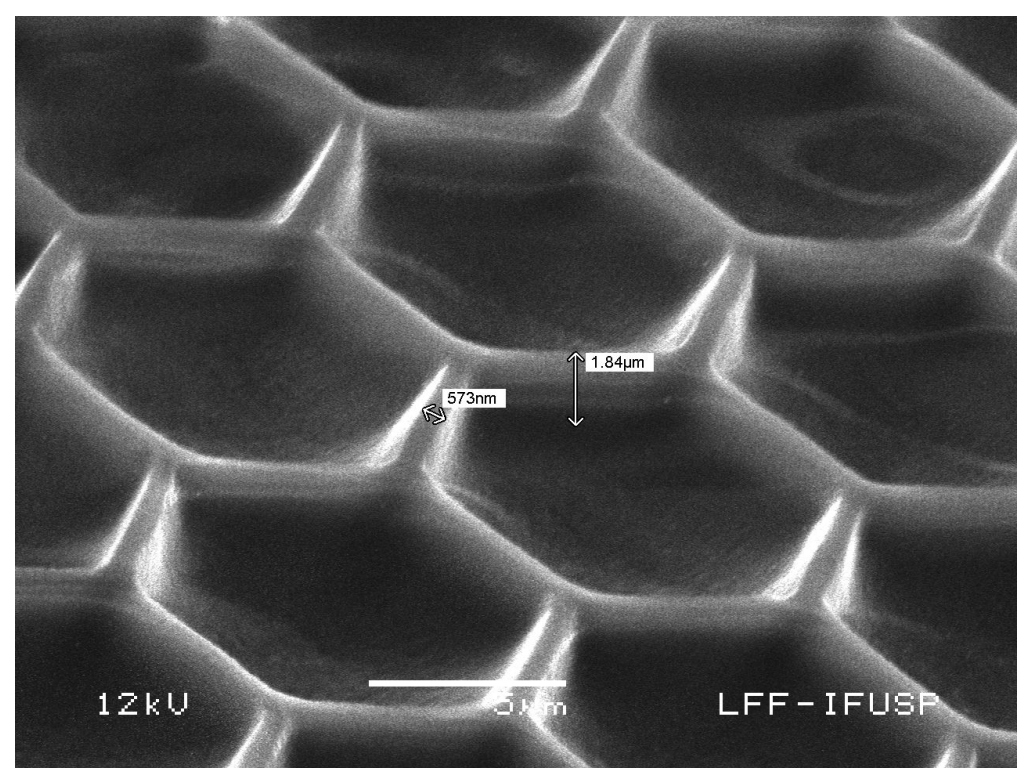

(d) Dose de $0,11 \mathrm{nC} / \mathrm{cm}$.

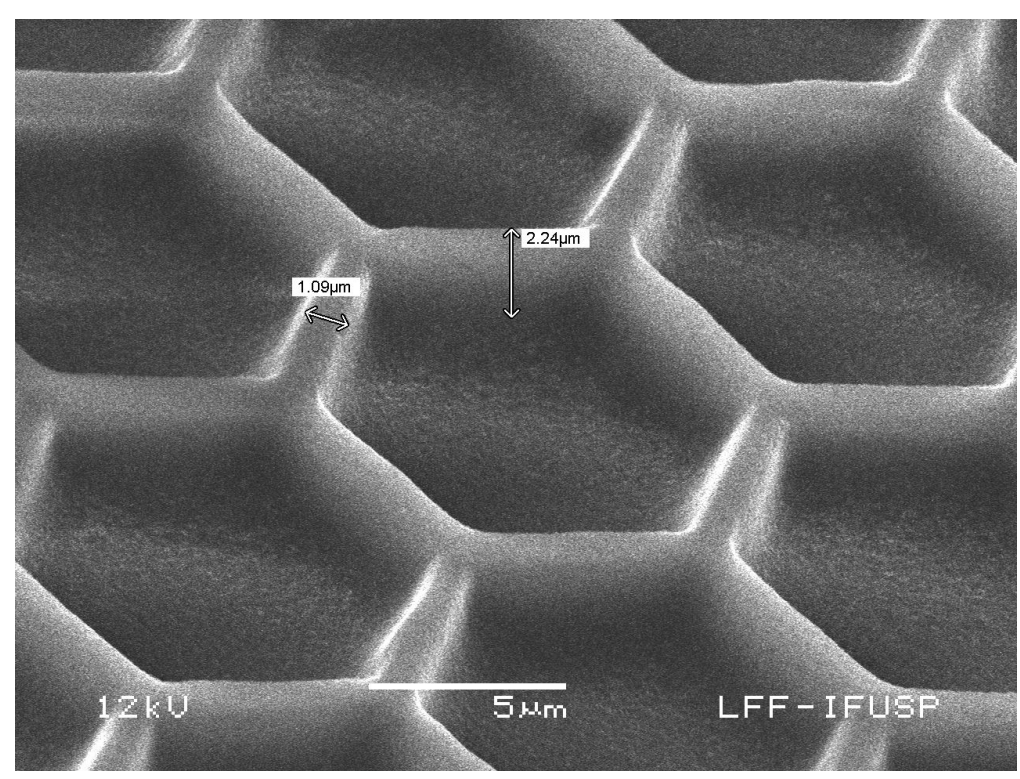

(e) Dose de $0,13 \mathrm{nC} / \mathrm{cm}$.

Figura A.4: Micrografias MEV de superfícies obtidas para corrente do feixe de elétrons de 20 pA com variação na dose, utilizada na litografia de cavidades hexagonais com $2 R=12 \mu \mathrm{m}$.

Por Microscopia de Força Atômica (AFM) foi possível verificar estas dimensões de forma mais precisa. Os valores obtidos são apresentados na tabela A.1:

Para microcavidade apresentando $2 R \approx 80 \mu \mathrm{m}$, o mesmo procedimento de calibração foi adotado. Das micrografias obtidas por MEV foi possível observar que para a corrente de 15 pA e dose de $0,07 \mathrm{nC} / \mathrm{cm}$ as microcavidades apresentavam paredes melhor definidas. Uma micrografia da amostra contendo microcavidades com $2 R \approx 80 \mu \mathrm{m}$ é apresentada na Figura A.5. As dimensões medidas através de AFM são apresentados na tabela A.2. 
Tabela A.1: Valores obtidos para as dimensões das microcavidades hexagonais através de medidas por AFM.

\begin{tabular}{|c|c|}
\hline \multicolumn{2}{|c|}{ Medidas para as dimensões de fabricação. } \\
\hline \hline Parâmetro & Valor obtido \\
\hline$\beta$ & $1,3 \mu \mathrm{m}$ \\
\hline $2 R$ & $12,2 \mu \mathrm{m}$ \\
\hline$h$ & $3,0 \mu \mathrm{m}$ \\
\hline
\end{tabular}

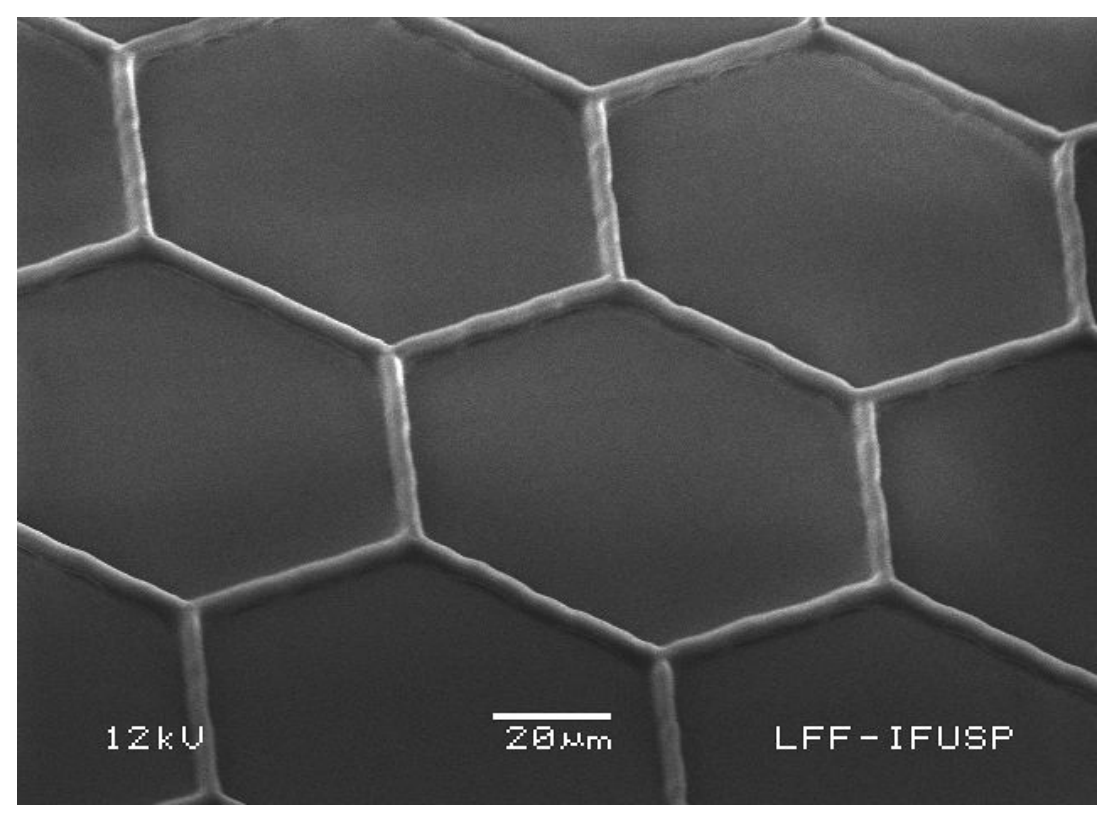

Figura A.5: Micrografia obtida por MEV para microcavidades com $2 R \approx 80 \mu \mathrm{m}$, produzidas com corrente de $15 \mathrm{pA}$ e dose de $0,07 \mathrm{nC} / \mathrm{cm}$.

Tabela A.2: Valores obtidos para as dimensões das microcavidades hexagonais de $2 R \approx 80 \mu \mathrm{m}$.

\begin{tabular}{|c|c|}
\hline \multicolumn{2}{|c|}{ Medidas para as dimensões de fabricação. } \\
\hline \hline Parâmetro & Valor obtido \\
\hline$\beta$ & $3,5 \mu \mathrm{m}$ \\
\hline $2 R$ & $80,8 \mu \mathrm{m}$ \\
\hline$h$ & $3,0 \mu \mathrm{m}$ \\
\hline
\end{tabular}


Apêndice 12

\section{Medidas do tamanho das células $\mathrm{CHO}$ por} MEV.

Para conhecer os tamanhos das células $\mathrm{CHO}$ realizamos microscopia eletrônica de varredura para cultura realizada sobre SU-8, como é apresentado nas figuras B.1 e B.2. A figura B.1 exemplifica o caso de uma célula no seu estado inicial de adesão no substrato de SU-8, apresentando uma morfologia aproximadamente circular, com diâmetro de cerca de $24 \mu \mathrm{m}$. A figura B.2 mostra diversas células, estando algumas espraiadas, onde podemos ver que os tamanhos das células $\mathrm{CHO}$, quando bem espraiadas, varia de 40 a $75 \mu \mathrm{m}$ de comprimento. A partir destas medidas fizemos a escolha dos tamanhos em que seriam realizadas as microcavidades hexagonais no material SU-8.

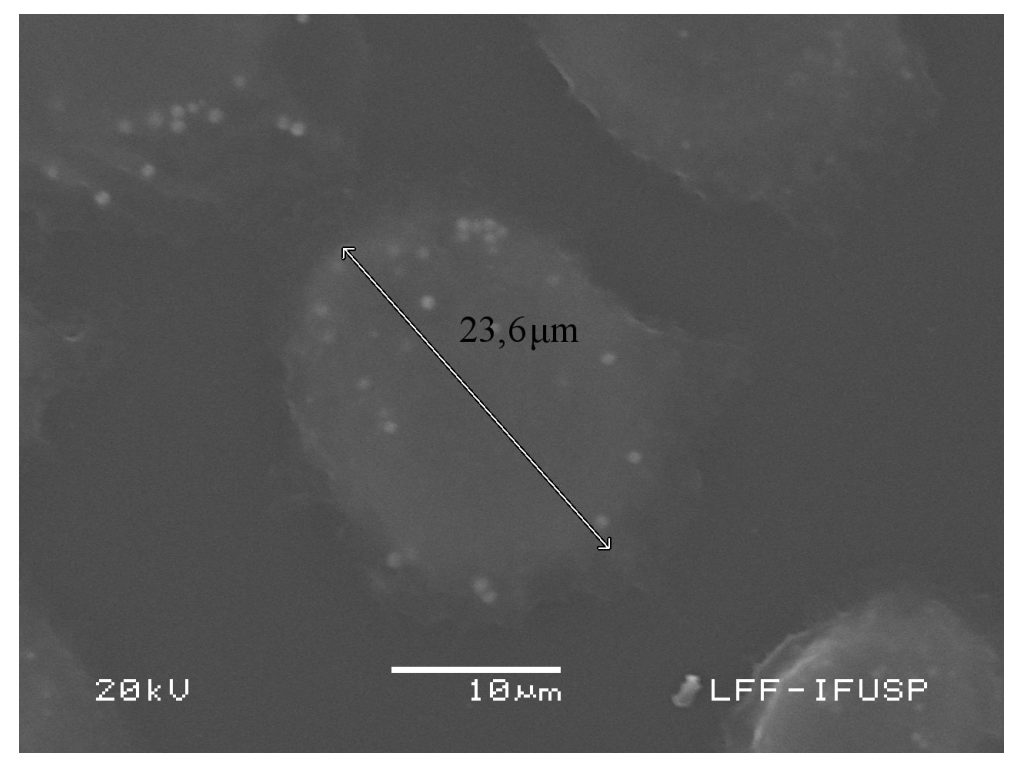

Figura B.1: Micrografia MEV de célula CHO no estado inicial de adesão ao material SU-8. 


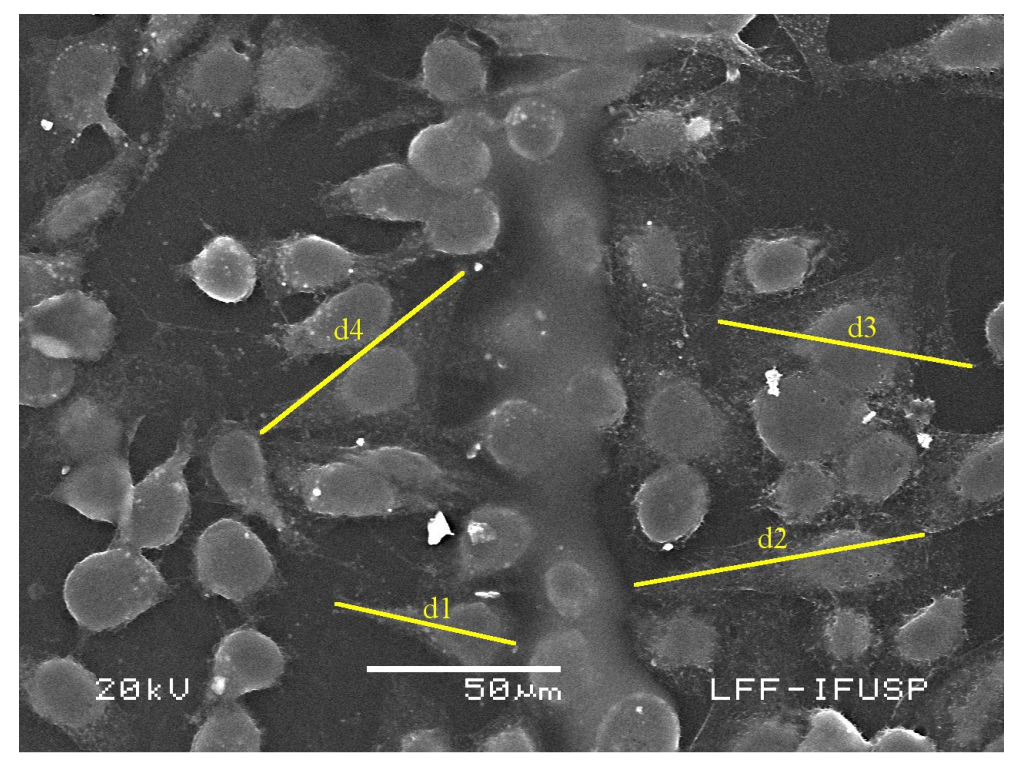

Figura B.2: Micrografia MEV de diversas células $\mathrm{CHO}$, estando algumas espraiadas, apresentando boa adesão ao material SU-8. Como exemplo, têm-se as medidas $d 1=48 \mu \mathrm{m}, d 2=75$ $\mu \mathrm{m}, d 3=63 \mu \mathrm{m}$ e $d 4=67 \mu \mathrm{m}$. 


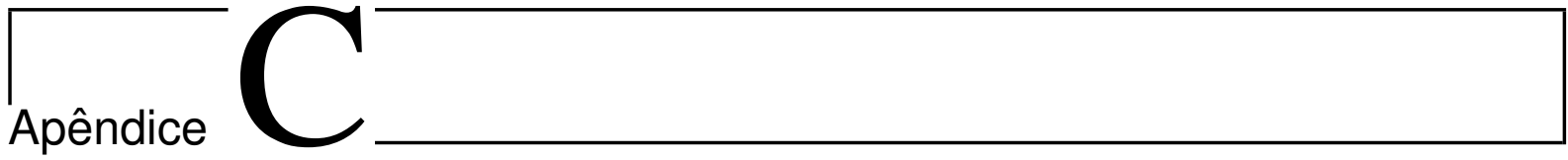

\section{Definição de número de células a serem}

\section{semeadas utilizando marcação de núcleos com o fluoróforo DAPI.}

Inicialmente fixamos o número de células semeadas na cultura de CHO para as marcações realizadas com trypan-blue e DAPI, utilizando o valor de $6 \times 10^{4}$ células por poço. Durante os primeiros experimentos utilizando DAPI, após as 24 horas de cultura, obtivemos uma baixa densidade de células por mm2 para culturas semeadas em SU-8, como pode ser observado na figura C.1.

Deste modo, fez necessário aumentarmos a quantidade de células semeadas para que pudéssemos trabalhar com fluoróforo DAPI e obter uma quantidade maior de núcleos refletindo em uma maior amostragem de células e redução da flutuação estatística. Para tal, semeou-se superfícies de SU-8 liso com as quantidades de células de $6 \times 10^{4}, 1,2 \times 10^{5}, 2,4 \times 10^{5}$ e 4,8 $\times 10^{5}$ células por poço. Os resultados são apresentados na figura C.2. Podemos observar que para o valor de $6 \times 10^{4}$ temos uma baixa quantidade de células na micrografia. Para o valor de $1,2 \times 10^{5}$ células vemos que houve uma distribuição uniforme de células sobre toda a superfície do material analisado. Para os valores de $2,4 \times 10^{5}$ e $4,8 \times 10^{5}$ células semeadas no material SU-8 vemos que essa quantidade de células é bastante elevada o que não era desejável. 


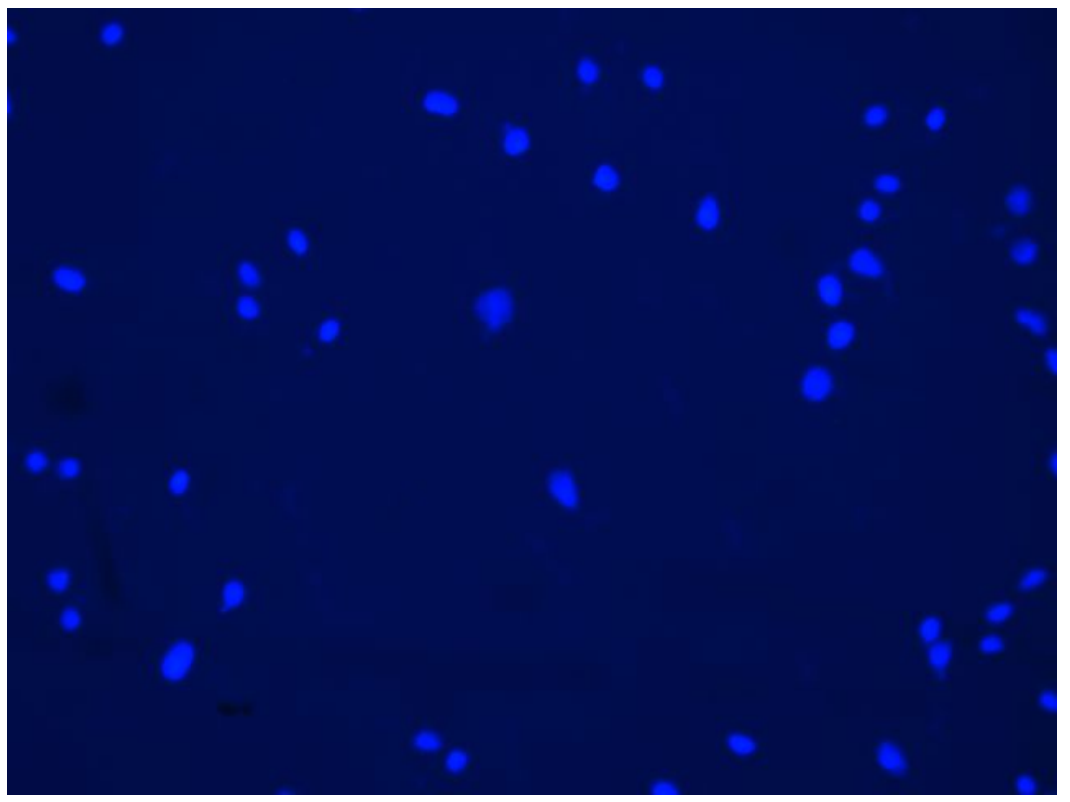

Figura C.1: Superfície de SU-8 semeada com $6 \times 10^{4}$ células, após as 24 horas de cultura, com os núcleos marcados com fluoróforo DAPI. Essa imagem possui tamanho de $437 \times 328 \mu \mathrm{m}^{2}$.

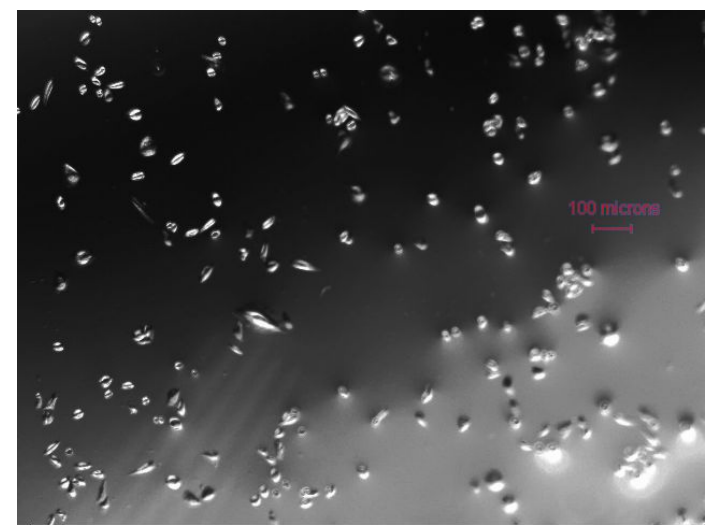

(a) SU-8 semeado com $6 \times 10^{4}$ células.

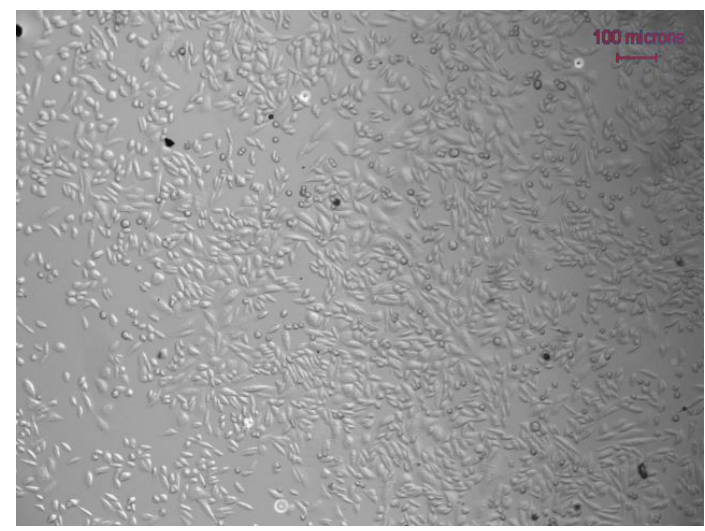

(c) SU-8 semeado com $2,4 \times 10^{5}$ células.

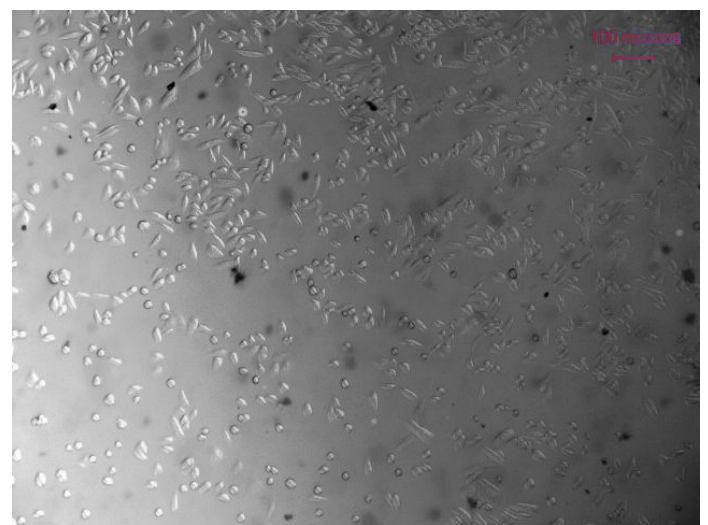

(b) SU-8 semeado com $1,2 \times 10^{5}$ células.

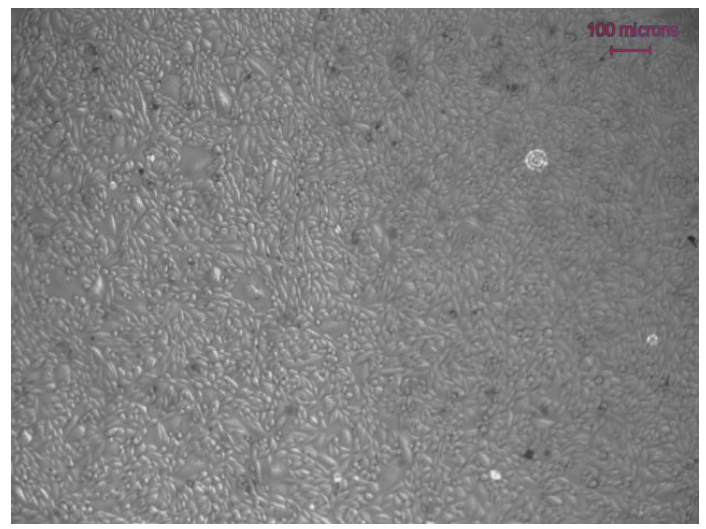

(d) SU-8 semeado com $4,8 \times 10^{5}$ células.

Figura C.2: Microscopias ópticas típicas das culturas celulares realizadas, após as 24 horas, no material SU-8 onde foi variado o número de células semeadas. 
Na figura C.3 apresentamos uma micrografia óptica de fluorescência para a superfície de SU-8 semeada com $1,2 \times 10^{5}$, onde os núcleos foram marcados com fluoróforo DAPI, apresentando uma densidade adequada para o estudo.

Figura C.3: Micrografia da superfície de SU-8 semeada com $1,2 \times 10^{5}$ células, após as 24 horas de cultura, e marcadas com o fluoróforo DAPI. Essa imagem possui tamanho de $437 \times$ $328 \mu \mathrm{m}^{2}$. 
Apêndice

\section{Parâmetros obtidos a partir da análise da função de correlação.}

Inicialmente discutiremos em detalhes o procedimento de obtenção do número de primeiros vizinhos, segundo a abordagem da seção 2.7.4, no contexto da análise da função de correlação utilizada neste trabalho. Para tal, criou-se 2 padrões com dimensões conhecidas dados nas figuras D.1a (padrão 1) e D.1b (padrão 2), que foram analisados pela função de correlação. Esses padrões foram primeiramente binarizados, onde foi associado o valor "1" para a cor branca e o valor "0" (zero) para a cor preta, viabilizando os cálculos de obtenção da função de correlação. Por simplicidade, nos padrões, os círculos não se sobrepõem e ainda colocamos um círculo localizado no centro do padrão. Uma vez calculadas as funções de correlação $\operatorname{Corr}(r)$, utilizando a equação 2.19, foram gerados os gráficos apresentados nas figuras D.2a e D.2b associados aos padrões 1 e 2 respectivamente, onde $r$ corresponde à distância em número de pixels. Nesses gráficos os dois primeiros picos correspondem às distâncias mais próximas entre dois centros de circunferência que se referem aos primeiros e segundos vizinhos. Estas distâncias também podem ser vistas na figura D.2a, como indicado por $r 1 \sim 95$ pixels e $r 2 \sim 122$ pixels. Os demais picos estão relacionados com os terceiros vizinhos, quartos vizinhos e assim por diante. Para o padrão 2, aumentamos em duas vezes a quantidade de circunferências que havia no padrão 1. Note que, deste modo as circunferências ficaram mais próximas umas das outras. Essas aproximações nas distâncias entre vizinhos são refletidas no gráfico de $\operatorname{Cor}(r)$ como um primeiro pico bem definido em torno de $r 1 \sim 50$ pixels na figura D.2b, o que corresponde ao pico de primeiros vizinhos indicado por $r$. Os demais picos estão relacionados com segundos vizinhos, indicado na figura D.2 por $r 2$, e os terceiros vizinhos, indicando na mesma figura por r3 e assim por diante. 


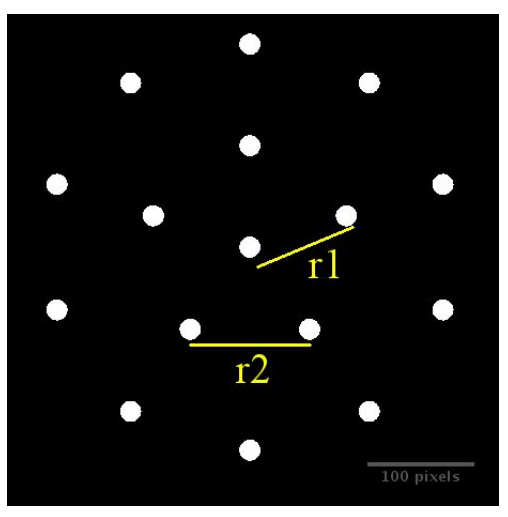

(a) Padrão 1.

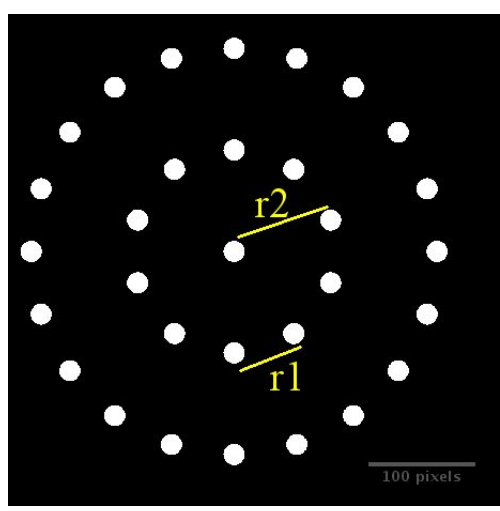

(b) Padrão 2.

Figura D.1: (a) Padrão contendo 16 circunferências. (b) Padrão contendo 31 circunferências. Estes padrões foram analisados pela função de correlação.

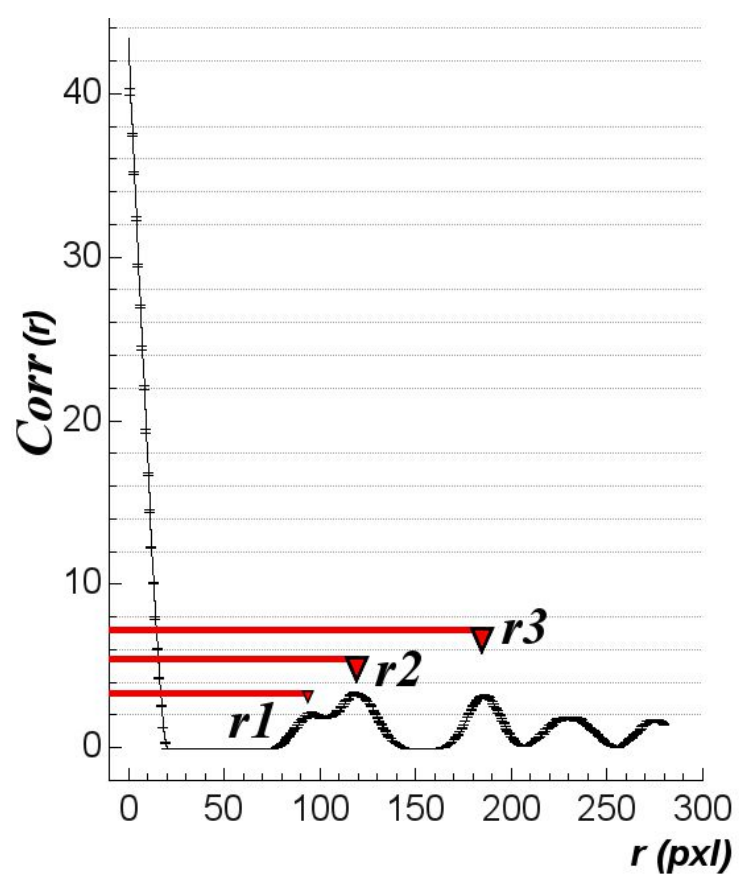

(a) Padrão 1.

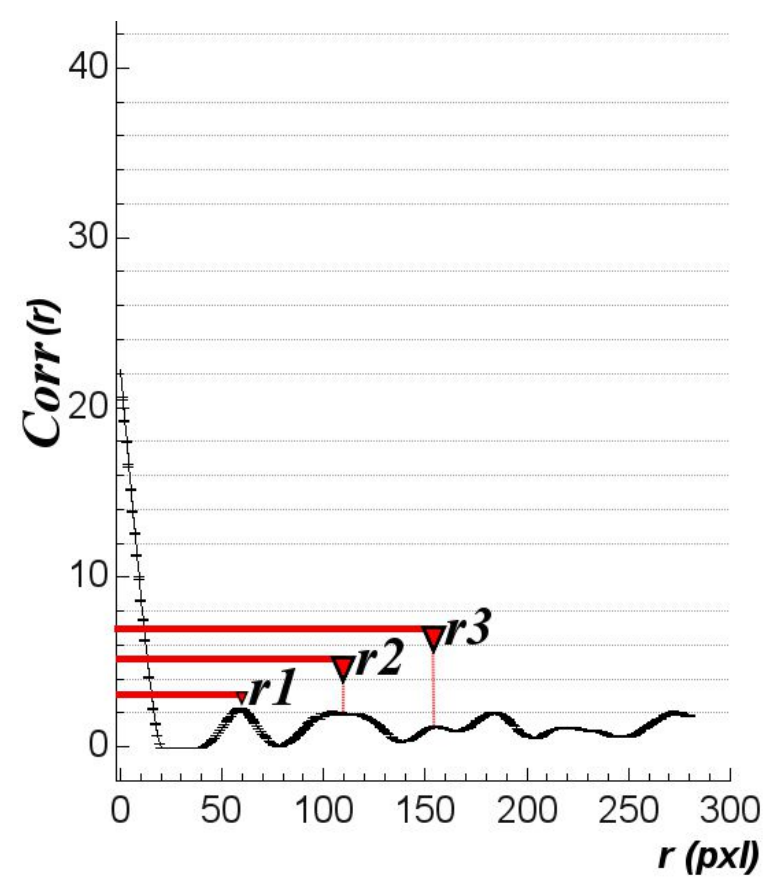

(b) Padrão 2.

Figura D.2: (a) Gráfico para a função de correlação $\operatorname{Corr}(r)$ calculado para o padrão 1. (b) Gráfico para a função de correlação $\operatorname{Corr}(r)$ calculado para o padrão 2.

Passemos agora a discutir a formação de aglomerados dentro do contexto da análise da função de correlação. Padrões onde partículas tendem a se agregar dentro de uma série de domínios circulares produzem funções de correlação que são oscilações amortecidas. A frequência dessas oscilações corresponde ao tamanho médio de domínio, ou seja, o raio dos aglomerados $\left(r_{c}\right)$. O decaimento, devido ao amortecimento, quantifica correlações entre domínios vizinhos, ou seja, define as distâncias entre aglomerados $\left(d_{c}\right)$ [169]. Para estes casos as funções de correlação podem ser ajustadas através de uma função de cosseno amortecido: $\operatorname{Cor} r(r)=$ 
$1+A \cdot \exp \left(-r / d_{c}\right) \cos \left(\pi r / r_{c}\right)$ (equação 2.20), em que $A$ é uma constante de normalização, $d_{c}$ é a distância entre aglomerados e $r_{c}$ é o raio dos aglomerados $[169,173]$.

Da função de correlação podemos ainda extrair o número médio de partículas aglomeradas $\langle N c\rangle$ e o número de primeiros vizinhos $N_{p}$. O valor de $\langle N c\rangle$ em uma determinada região da imagem delimitada entre os raios $R_{\min }$ e $R_{\max }$, pode ser calculada de acordo com a seguinte equação [173]:

$$
\langle N c\rangle=1+\rho\left(\int_{R_{\min }}^{R_{\max }}(\operatorname{Corr}(r)-1) 2 \pi r d r\right)
$$

onde $\rho$ é a densidade de partículas por área e $\operatorname{Corr}(r)$ é a função de correlação obtida da imagem. O número de primeiros vizinhos $N_{p}$ pode ser calculado utilizando-se a seguinte equação:

$$
N_{p} \approx \frac{2 N_{T}}{3 \pi\langle N c\rangle}
$$

onde $N_{T}$ representa o número total de circunferências (células) na imagem e $\langle N c\rangle$ é o número médio de partículas (células) contidas nos aglomerados, dado pela equação D.1. Note que, para calcular o número de primeiros vizinhos $(N p)$ na equação D.2, precisamos calcular inicialmente o número médio de partículas aglomeradas $\langle N c\rangle$ na região correspondente às distâncias de primeiros vizinhos. Considerando o gráfico da função de correlação $\operatorname{Cor} r(r)$ dado na figura D.3, os valores de $R_{\min }$ e $R_{\max }$ devem corresponder às distâncias de primeiros vizinhos que delimitam o pico.

Dessa forma, a análise da função de correlação permitiu calcular neste trabalho as distâncias de primeiros, segundos e terceiros vizinhos, tamanhos de aglomerados, distância entre os aglomerados e o número de primeiros vizinhos. 


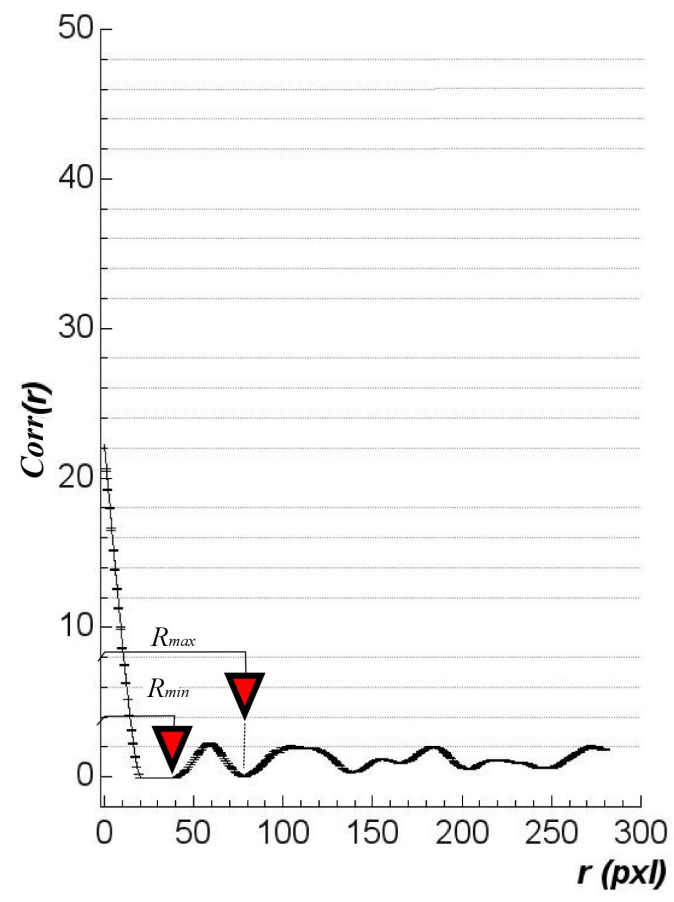

Figura D.3: Ilustração de um gráfico de $\operatorname{Cor} r(r)$, indicando a região de integração para o cálculo do número médio de partículas aglomeradas $\langle N c\rangle$ para o primeiro pico (primeiros vizinhos). 
Apêndice

\section{Protocolos de Cultura.}

Nas próximas páginas diponibilizaremos todos os protocolos de cultura que foram utilizados neste trabalho. 


\section{Materiais}

1 Falcon de $15 \mathrm{~mL}$ (outro Falcon de $15 \mathrm{~mL}$ deve estar na centífuga com mesmo volume)

2 pipetas plásticas de $10 \mathrm{~mL}$

1 pipeta plástica de $1 \mathrm{~mL}$

1 garrafinha de $25 \mathrm{~cm}^{2}$ (que não pode ser exposta ao UV)

1 béquer de vidro de $100 \mathrm{~mL}$ para descarte

Caneta para escrever na garrafinha

1- Limpar fluxo laminar com solução de virkon

2 - Limpar embalagem pipetas e fluxo laminar com álcool 70\%

3 - Colocar os demais materiais dentro do fluxo laminar (menos garrafinha)

4 - Colocar meio completo (100mL HAM F-10, 10mL de SFB e 1,1 mL de antibiótico) no banhomaria por $20 \mathrm{~min}$

5 - Ligar Luz UV por 20 min e aguardar fora da sala

6- Colocar $9 \mathrm{~mL}$ de meio completo em um tubo Falcon de $15 \mathrm{~mL}$ ( $9 \mathrm{~mL}$ se for usar 1 criotubo, $8 \mathrm{~mL}$ se for usar 2 criotubos, etc)

7- Colocar $10 \mathrm{~mL}$ de meio completo em um frasco de cultura de $25 \mathrm{~cm}^{2}$ (garrafinha)

8- Escrever na garrafinha " $\mathrm{OP}$ ” $\mathrm{CHO}$ e data.

9-Tirar as células do galão de nitrogênio e anotar o lote que será descongelado (Por exemplo: Lote descongelado CHO 06/02/2012)

10 - Com o criotubo ainda fechado da uma flambada de leve.

11- Esperar suspensão celular descongelar no criotubo, quando começar a descongelar jogar todo o volume no tubo Falcon que contem meio (isso deve ser feito rápido, pois o DMSO pode estragar as células)

12- Quando abrir o criotubo dar flambada de leve na boca. Despejar o criotubo

13- Misturar levemente agitando o tubo Falcon (bate no fundo de leve)

14- Colocar o tubo Falcon na centrifuga a 1000 rpm por $5 \mathrm{~min}$

15-Retirar sobrenadante (sem pressa, sem gerar bolhas e com pipeta na parede oposta ao pellet). Deve-se deixar apenas $500 \mu \mathrm{L}$.

16- Homogeneizar com pipeta e colocar as células em frasco de cultura de $25 \mathrm{~cm}^{2}$ contendo $10 \mathrm{~mL}$ de meio completo

17 - Colocar garrafinha na incubadora e anotar o horário

18- Quando se descongela no outro dia só se troca o meio de cultura se garrafinha não estiver confluente. Se estiver confluente, repica.

19 - Retirar descartes, limpar fluxo com virkon, com álcool 70\% e ligar UV por 20 minutos. 


\section{Materiais}

3 pipetas plásticas de $5 \mathrm{~mL}$

1 pipeta plástica de $10 \mathrm{~mL}$

1 pipeta plástica de $1 \mathrm{~mL}$

2 garrafinhas de $25 \mathrm{~cm}^{2}$ (que não pode ser exposta ao UV) - (ou quantas forem necessárias)

1 pipeta pasteur autoclavada

1 béquer de vidro de $100 \mathrm{~mL}$ para descarte

Caneta para escrever na garrafinha

1- Limpar fluxo laminar com solução de virkon

2 - Limpar embalagem pipetas e fluxo laminar com álcool 70\%

3 - Colocar os demais materiais dentro do fluxo laminar (menos garrafinha)

4 - Colocar meio completo (100mL HAM F-10, 10mL de SFB e 1,1 mL de antibiótico), solução de Hanks e tripsina (alíquotas de 10mL) no banho-maria por $20 \mathrm{~min}$

5 - Ligar Luz UV por 20 min e aguardar fora da sala

6- Olhar garrafinha(s) no microscópio óptico invertido e se certificar de que está $90 \%$ confluente

7- Descartar o meio das garrafinha(s) (frascos de $25 \mathrm{~cm}^{2}$ )

8- Colocar $5 \mathrm{~mL}$ de solução de Hanks na(s) garrafinha (s) usando pipeta de $5 \mathrm{ml}$. Obs: Não jogar o jato na parede onde as células estão aderidas. (Trocar de pipeta se garrafinhas estiverem em diferentes passagens)

9- Agitar a(s) garrafinha(s) com a solução de Hanks delicadamente

10- Virar no descarte

11- Pegar pipeta Pasteur de vidro pequena e retirar qualquer sobra da solução de Hanks

(Trocar de pipeta se garrafinhas estiverem em diferentes passagens)

12- Colocar $2 \mathrm{~mL}$ de tripsina na(s) garrafinha(s) (com pipeta de $5 \mathrm{~mL}$ ), jateando na parede oposta à das células. (Trocar de pipeta se garrafinhas estiverem em diferentes passagens)

13- Colocar a(s) garrafinha(s) durante 5 minutos na incubadora com a tripsina em contato com as células

14- Enquanto isso, colocar $10 \mathrm{~mL}$ de meio completo na(s) garrafinha(s)

15- Verificar se as células soltaram, senão, dar uma batidinha de leve na lateral da(s) garrafinha(s)

16- Quando as células descolarem, inibir a tripsina com $2 \mathrm{~mL}$ de meio completo.

(Trocar de pipeta se garrafinhas estiverem em diferentes passagens)

17- Usar pipeta de $1 \mathrm{~mL}$ para colocar as células soltas no meio. Para homogeneizar subir e descer a solução na pipeta tentando enxaguar as paredes e misturar as células. (Trocar de pipeta se garrafinhas estiverem em diferentes passagens) 
18- Colocar a pipeta de $1 \mathrm{~mL}$ dentro do meio para evitar bolhas para colocar suspensão celular. Tomar cuidado para não molhar a boca da(s) garrafinha(s), e nem não formar espuma.

19- Escrever em cada garrafinha seu número, o tipo de célula, a passagem, a data de descongelamento e o experimentador. Ex: 1/CHO/1P/22-07-13/WW

20- Deixar a tampa um pouquinho aberta e colocar a(s) garrafinha com células na estufa.

21- Passar parafilme em todos os frascos

22- Retirar descartes, limpar fluxo com virkon, com álcool 70\% e ligar UV por 20 minutos. 


\section{Protocolo de Contagem das células}

\section{Procedimento}

- Repicar as células.

- Colocar as células em tubos de Falcon de $15 \mathrm{ml}$.

- Centrifugar por 5 minutos a $800 \mathrm{rpm}$.

- Retirar o meio, deixando apenas $500 \mu 1$.

- Pegar 10 ul com auxílio de uma micropipeta e pipetar na câmara de Neubauer na parte de cima.

- Pipetar outros $10 \mu 1$ na parte de baixo.

- Colocar a câmara de Neubauer no microscópio invertido e efetuar a contagem (ver texto a seguir)

- Em seguida, ajustar a quantidade de células para que cada garrafinha contenha $1 \times 10^{6} \mathrm{cel} /$ $\mathrm{mL}$.

- Colocar as células em frasco de cultura de $25 \mathrm{~cm}^{2}$ contendo $10 \mathrm{ml}$ de meio completo. Colocá-las na estufa a $37^{\circ} \mathrm{C}$ e $5 \%$ de $\mathrm{CO}_{2}$.

Mais informações importantes sobre como contar células (Conferir no Capítulo 2 Seção 2.4.3)

A câmara de Neubauer é uma lâmina espessa retangular e normalmente de vidro. A lâmina possui uma região de depressão (câmara) no centro de um volume conhecido, utilizada para fazer contagem de células por unidade de volume de uma suspensão. Esta câmara é gravada com uma grade de linhas perpendiculares (ver Figura 4). Esta grade é cuidadosamente elaborada, de modo que a área delimitada pelas linhas é conhecida, e a profundidade da câmara é também conhecida. $\mathrm{Na}$ grade de linhas existem três tipos de quadrantes denominados $\mathrm{A}, \mathrm{B}$ e C, de medidas conhecidas, que juntos formam um quadrado maior. A partir do número de células contidas no quadrante de interesse é possível contar o número de células ou partículas de um volume específico de fluido, e, assim, calcular a concentração de células no líquido total.

A área total compreendida pelas 9 regiões é de $9 \mathrm{~mm}^{2}$ sendo que cada região (A, B e C) quadrados de 1 x $1 \mathrm{~mm}^{2}$ (ver Figura 4). Ao ser colocada a lamínula de vidro (especial para ser usada na câmara de Neubauer) a distância da lamínula até a lâmina (profundidade) mede 0,1 mm, o que permite se obter um volume de $0,1 \mathrm{~mm}^{3}$ em cada quadrante. 


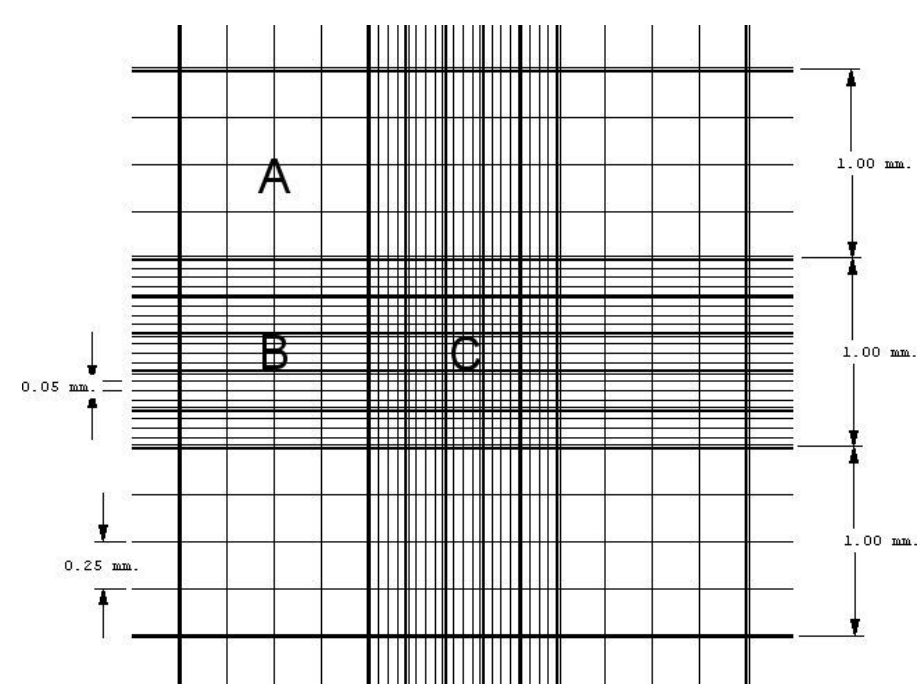

Figura 4: Figura ilustrativa do padrão gravado na câmara de Neubauer.

No procedimento de contagem as células foram lavadas com solução de Hanks e em seguida tripsinizadas. Nos processos de tripsinização foi utilizado uma solução balanceada com tripsina (2,5 g/L) sem íons cálcio e magnésio e com um agente quelante (EDTA), fornecido pela empresa Cultilab (SP, Brasil). Esta solução age permitindo o desprendimento de células aderentes dos frascos de cultivo, além de desagregar as células entre si através de sua ação proteolítica sobre proteínas intercelulares e, alterar a estabilidade das membranas ao quelar o íon cálcio. Uma vez que as células descolaram da parede do frasco de cultura estas foram passadas para tubos de Falcon de $15 \mathrm{~mL}$. Um volume de $10 \mu \mathrm{L}$ da suspensão de células foi coletado com auxílio de uma micropipeta e pipetado na parte de cima da câmara de Neubauer e outros $10 \mu \mathrm{L}$ da suspensão de células foram pipetados na parte de baixo. No microscópio óptico foi efetuada a contagem.

Fizemos a contagem de células na região C (ver Figura 4) da câmara de Neubauer, mais precisamente nos 5 quadrados da diagonal dessa região; o valor foi divido por 5, assim temos uma estimativa de células por quadrado. O valor final foi multiplicado por 25 que é o número total de quadrados contidos na região C. Assim obtivemos o valor quantitativo de células. Para obter o valor de células em suspensão, ou seja, o número de células $/ \mathrm{mL}$, tivemos que dividir o valor quantitativo obtido pelo volume da câmara na região $\mathrm{C}$ que é de $10^{-4} \mathrm{~mL}$.

Assim temos que;

$$
\mathrm{n}^{\circ} \text { de células } / \mathrm{mL}=\left(\frac{\mathrm{n}^{\circ} \text { total de células }}{\mathrm{n}^{\circ} \text { de quadrados contados }}\right) \times \text { fator de diluição } \times 10000
$$


onde o fator de diluição adotado foi de 1 . Deste modo o número de células desejadas será dado pela expressão

$n^{o}$ de células $/ m L$ da suspensão original $\mathrm{x}$ volume original $=$ volume final $\mathrm{x}$ concentração de células desejada/ $m L$

ou

$\left(\frac{\mathbf{n}^{\circ} \text { de células } / \mathrm{mL} \text { da suspensão original }}{\text { número de células desejadas } / \mathrm{mL}}\right) \times$ volume original $=$ volume final (2.3) 


\section{Teste de viabilidade usando trypan blue (azul de trypano)}

\section{1) Contagem das células que se descolaram da superfície}

Inicialmente, retire o meio $(1 \mathrm{ml})$ que foi usado para manter as células em cultivo. Coloque o meio em um tubo eppendorf de 1,5 ml. Feche o tubo. Coloque o eppendorf em um tubo de Falcon de $15 \mathrm{ml} \mathrm{sem} \mathrm{tampa} \mathrm{(o} \mathrm{eppendorf} \mathrm{vai} \mathrm{ficar} \mathrm{pendurado} \mathrm{nas} \mathrm{bordas}$ do tubo de Falcon). Centrifugue o tubo de Falcon contendo o tubo eppendorf por 5 minutos a $1000 \mathrm{rpm}$. Retire o tubo eppendorf do tubo de Falcon e coloque em um suporte. Retire com uma micropipeta de $1000 \mu \mathrm{l}, 950 \mu \mathrm{l}$ de meio do tubo eppendorf e jogue fora (dentro do eppendorf vai ficar somente $50 \mu \mathrm{l}$ ). CUIDADO PARA NÃO TOCAR NO FUNDO DO TUBO OU NO PELLET CELULAR COM A PONTEIRA QUANDO ESTIVER RETIRANDO O LÍQUIDO. Quando sobrar somente os $50 \mu \mathrm{l}$, com o auxílio de uma micropipeta de $100 \mu \mathrm{l}$, misture o meio tentando dissolver o pellet celular, se houver, e lavando a parede do tubo (pode fazer isso aspirando e soltando com a micropipeta). Posteriormente, em outro eppendorf coloque $10 \mu \mathrm{l}$ dos $50 \mu \mathrm{l}$ que havia no outro tubo. No tubo com $10 \mu \mathrm{l}$, adicione $10 \mu \mathrm{l}$ de trypan blue (já vem pronto para uso). Com o auxílio da micropipeta de $10 \mu \mathrm{l}$ (aspirando e dispensando) misture bem o trypan blue com as células. Espere por 5 minutos, homogeneíze com a micropipeta novamente e coloque $10 \mu \mathrm{l}$ desta solução na parte de cima e $10 \mu \mathrm{l}$ na parte de baixo da câmara de Neughbauer. Como a quantidade de células vai ser muito pequena, conte o número de células dos 25 quadrados, tanto de cima quanto de baixo. Divida por 2. O resultado obtido deve ser multiplicado por $10^{4}$. Assim, o número encontrado vai ser, por exemplo, X células/ml. Para você saber quantas células morreram, descolando da superfície, você deverá fazer uma regra de 3, ou seja,

$$
\begin{aligned}
& \mathrm{X} \text { cels - } 1000 \mu \mathrm{Y} \quad \mathrm{Y}=(\underline{50 \times \mathrm{X}) \times 2} \text { cels } \\
& \text { Y cels - } 50 \mu \mathrm{l}
\end{aligned}
$$

$\mathrm{Y}=$ número de células mortas naquela amostra que estavam no meio

Obs: É necessário contar o número de células no meio, porque muitas delas morreram e se despregaram da superfície.

\section{2) Contagem das células "em processo de morte" que estão na superfície}

Em um tubo eppendorf de $1 \mathrm{ml}$, dilua $50 \mu \mathrm{l}$ de meio fresco com $50 \mu \mathrm{l}$ de trypan blue. Misture com o auxilio de uma micropipeta. Pingue sobre a superfície uma quantidade suficiente desta solução (trypan blue + meio) até cobrir (como vocês estão fazendo para micrografar). Espere por 5 minutos. Coloque uma lamínula. Leve ao microscópio e conte 100 células em cada quadrante, independente se elas estiverem viáveis ou não viáveis. Veja destas 100 células quantas eram viáveis e quantas eram viáveis. Veja a figura abaixo: 


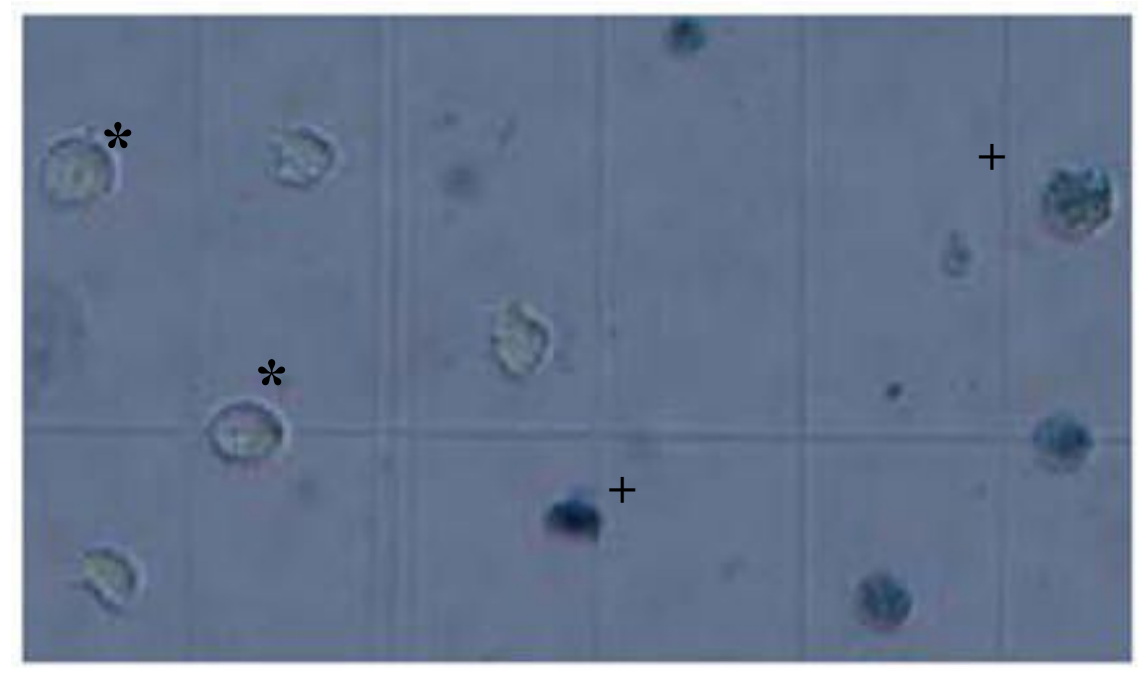

Figura: Ilustração de células viáveis(*) e células inviáveis (+) marcadas por trypan blue 


\section{Procedimento de uso da solução Fixadora para MEV.}

1- Após 24 h nos poços (no caso de células semeadas em amostras)

2- Descongelar tetróxido de ósmio

3- Tirar o meio sem encostar na amostra

4- Lavar com tampão cacodilato ( $0,05 \mathrm{M}) 4 \mathrm{X} 1 \mathrm{ml}$ suficiente

Obs.: Tentar não jogar em cima da superfície, jogar na parede do poço.

5- Fechar poços e agita delicadamente

6- Retirar e fazer a mesma coisa $3 \mathrm{X}$

7- Antes do fixador, tirar o máximo do cacodilato

Obs.: nunca encostar a pipeta na superfície da amostra

8- Colocar solução fixadora com pipeta de vidro, o suficiente para cobrir a amostra.

Obs.: Pode até não colocar sobre as amostras mas não pode encostar.

9- Deixar por 30 min na solução fixadora

10- Retirar tudo

11- Lavar com tampão cacodiltato (0,05 M) $4 \mathrm{X}$

12- colocar pós fixador (tetróxido de ósmio) só cobrir as amostras.

Obs: 1- Muito Perigoso!!!!

2- As amostras ficarão escuras.

13- Deixar por 20 min na solução pós fixadora

14- Retirar tudo

15- Desidratação em concentrações crescentes de etanol.

15-1 etanol 30\% por 3 minutos

Obs.: descartar a primeira passagem de etanol no descarte de tetróxido de ósmio

15-2 etanol $50 \%$ por 3 minutos

15-3 etanol $70 \%$ por 3 minutos

15-4 etanol $80 \%$ por 3 minutos

15-5 etanol $90 \%$ por 3 minutos

15-6 etanol 95\% por 3 minutos

15-7 etanol $100 \%$ por 3 minutos

16- Dessecação com HMDS por 10 minutos. Colocar suficiente p/ cobrir

17- Descartar HMDS no descarte do tetróxido de ósmio

18- Retirar tudo e colocar para secar em temperatura ambiente 
Continuação de Procedimento de uso da solução Fixadora para MEV

19- Secar por 3 dias em temperatura ambiente

20- Metalizar no $3^{\circ}$ dia ( 60 s segundos com ouro).

\section{Preparando a solução fixadora.}

1) Fazer $200 \mathrm{ml}$ de solução tampão cacodilato 0,05 M. Colocar 2,14 g em $200 \mathrm{ml}$ de água.

2) Fazer $200 \mathrm{ml}$ de solução tampão cacodilato 0,1 M. Colocar 4,28 g em $200 \mathrm{ml}$ de água.

3) Fazer solução fixadora $25 \mathrm{ml}$ (1 ml por poço, no caso de 24 poços), usa-se 2,7 ml (formaldeído) + $100 \mu \mathrm{l}$ (gluta) $+22,2 \mathrm{ml}$ de cacodilato 0,1 M.

4) Fazer $24 \mathrm{ml}$ de tetróxido de ósmio 1\% dissolvido em tampão cacodilato 0,1 M. Usa-se $24 \mathrm{ml}$ de cacodilato $0,1 \mathrm{M}+(240 \mu \mathrm{l}$ ou 0,24 ml) de tetróxido de ósmio.

5) Prepara-se $25 \mathrm{ml}$ de cada concentração de etanol.

6) Etanol 30\% usar 7,5 ml (etanol absoluto)+17,5 ml(água)

7) Etanol 50\% usar 12,5 ml(etanol absoluto)+12,5 ml(água)

8) Etanol 70\% usar 17,5 ml (etanol absoluto)+7,5 ml(água)

9) Etanol 80\% usar 20,0 ml (etanol absoluto)+ 5,0 ml(água)

10) Etanol $90 \%$ usar 22,5 ml(etanol absoluto)+2,5 ml(água)

11) Etanol 95\% usar 23,75 ml(etanol absoluto)+1,25 ml(água)

12) Etanol $100 \%$ usar $25 \mathrm{ml}$ de etanol absoluto 
Protocolo para fixação + DAPI para Microscopia de Fluorescência - Julho de 2013

\section{Materiais}

1 placa de poços reutilizada / Ponteira P1000 (azul, de fora da sala de cultura) /Ponteira P10 (vermelha) / 10 ponteiras de $1 \mathrm{~mL} / 1$ ponteira de $10 \mathrm{uL}$

Tirar a placa de poços da incubadora e transferir amostras para uma placa de poços reutilizada limpa, com poços devidamente identificados

1-) Enxagüe as amostras em $3 x$ PBS $1 \mathrm{X} 1 \mathrm{M}$, previamente aquecido a $37^{\circ} \mathrm{C}$

Para cobrir uma amostra são necessários $700 \mu \mathrm{L}$. Para isto usar 3 x 1 ponteiras de $1 \mathrm{~mL}$;

Ex: Para 5 amostras $-3,5 \mathrm{~mL}$ x $3 \sim 11 \mathrm{~mL}$

2-) Fixe as células em Temperatura ambiente com solução de paraformaldeído a 4\% por 15 minutos

2.1-) Usar $1 \mathrm{~mL}$ por poço. Para isto usar ponteira de $1 \mathrm{~mL}$;

Ex: Para 5 amostras - $5 \mathrm{~mL}$

Para preparar paraformaldeído a $4 \%$

- 4 g de paraformaldeído

- $10 \mathrm{~mL}$ de PBS $1 \mathrm{X}, 1 \mathrm{M}$. Para isto usar pipeta de $10 \mathrm{~mL}$

- $90 \mathrm{~mL}$ de água deionizada

Aquecer a 50 graus em uma garrafa com tampa solta e peixinho magnético. O tempo de preparo é de $\sim 1$ hora e 30 min.

3-) Enxagüe as células 3 X em solução $0.2 \%$ de Triton X100 em PBS 1X 1M por 5 min cada

3.1-)Usar $500 \mu \mathrm{L}$ por poço.Para isto usar $3 \times 1$ ponteiras de $1 \mathrm{~mL}$;

Ex: 3,0mL solução final cada enxagüe de 5 amostras, 3 enxagües totais, $\sim 9 \mathrm{~mL}$ de solução final $9 \mathrm{~mL}$ de solução final, $18 \mu \mathrm{L}$ de Triton

Preparar a solução em tubo Falcon de $15 \mathrm{~mL}$ :

Verter $9 \mathrm{~mL}$ de PBS 1X 1M. Para isto usar pipeta de $10 \mathrm{~mL}$

Adicionar $18 \mathrm{uL}$ de Triton X-100;

Usando Pipeta de 5mL subir e descer várias vezes para homogeinezar a solução final.

\section{4-) Enxagüe 3X em PBS 1X 1M.}

Para cobrir uma amostra são necessários $700 \mu \mathrm{L}$. Para isto usar 3 x 1 ponteira de $1 \mathrm{~mL}$;

Ex: Para 5 amostras $-3,5 \mathrm{~mL}$ x $3 \sim 11 \mathrm{~mL}$

5-) Aplicar Gold ProLong with DAPI

- Remover o Gold Prolong DAPI da geladeira e deixar equilibrar a temperatura ambiente. (não aquecer)

- As amostras serão montadas em lâminas previamente esterelizadas em alcool 70\% por pelo menos $30 \mathrm{~min}$.

- As amostras devem estar sem excesso de líquido. Deixar secar um pouco ao ar ou pode ser usado papel de fitro para gentilmente tocar a superfície

- Transferir uma alíquota ( $\sim 3$ gotas) de DAPI para eppendorf de $0,5 \mathrm{~mL}$

- Com as amostras sem umidade, aplicar $20 \mu \mathrm{L}$ em cada amostra(o suficiente para cobrir a superfície da amostra.) Para isto usar ponteira de $10 \mu \mathrm{L}$;

- Cobrir a superfície gentilmente com uma lamínula de microscopia limpa e previamente esterelizado em alcool $70 \%$ por pelo menos $30 \mathrm{~min}$.

- Incubar por $24 \mathrm{~h}$ na temperatura ambiente em um local escuro

- Após a cura de 24 h, selar as bodas da lamínula com esmalte para unhas. 
Apêndice

Resumo publicado em revista indexada. 


\title{
CHO cell adhesion on modified surfaces of different materials.
}

\author{
WW Araújo ${ }^{1}$, MC Salvadori ${ }^{1}$, FS Teixeira ${ }^{1}$, HJM Amorim $^{1}$, GN Silva $^{2}$, DMF Salvadori $^{2}$ IG Brown $^{3}$ \\ ${ }^{1}$ Institute of Physics, University of São Paulo, São Paulo S.P., Brazil ${ }^{2}$ Department of Pathology, \\ Center for Genotoxins and Carcinogens Evaluation, TOXICAN, Botucatu Medical School, UNESP, \\ SP Brazil ${ }^{3}$ Lawrence Berkeley National Laboratory, Berkeley, California 94720, USA.
}

\begin{abstract}
INTRODUCTION: Epithelial cells are mainly responsible for the formation of tissues that cover the external and internal surfaces of organs like skin, lining of the lungs and intestines. The cells must adhere to substrates and to each other in compliance with certain stimulus. In this way, adhesion properties can be regulated by the cell which simultaneously senses the chemical and mechanical properties of its environment. Their adhesion and growth on biomaterials depends on substrate properties such as surface wettability, topography and chemistry. The aim of this study is to investigate cell-surface interactions using several materials and different surfaces.
\end{abstract}

METHODS: We have used several materials with different surface chemistry/morphology to study the interaction between surfaces and the $\mathrm{CHO}$ (Epithelial Chinese hamster ovary) cells. The materials used were SU-8 2005 (epoxy electron resist from Microchem), PDMS (polydimethylsiloxane from Down Corning), DLC (Diamond like carbon, ta-C (tetrahedral amorphous carbon)). Ordinary cover slip glass was used as reference. Samples with flat surfaces for each genuine material were produced. As surface modification techniques we used electron-beam lithography, ion implantation and plasma modification. For surface modification by electron beam lithography we have used SU-8 2005 as material and hexagonal cavities with inscribed diameters of 12, 80, 270 and $580 \mu \mathrm{m}$ were used as different scale patterns. For surface modification by plasma processing we have used DLC (ta-C) thin film as material, deposited by cathodic arc plasma gun. The DLC (ta-C) surfaces were modified by hollow cathode plasma gun fed up with oxygen or sulfur hexafluoride gas. Silver ion implantation was made for SU-8 2005 using a low cost Inverted Ion Source using Ag energy of - 4 $\mathrm{keV}$ and dose of $1.0 \times 10^{16} \mathrm{~cm}^{-2}$. We have also produced a hybrid SU-8/PDMS sample. For that, we deposited a SU-8 thin film on PDMS bulk piece and did SU-8 lithography with hexagonal cavities pattern. Is this way, we obtained hexagons with SU-8 walls $64 \mu \mathrm{m}$ wide and with inscribed diameter of $134 \mu \mathrm{m}$ made of PDMS. Thus, we ended up with a total of 12 different samples. $\mathrm{CHO}$ cells were purchased from the American Tissue Culture Collection (ATCC). Cells were cultured in tissue culture flasks $\left(25 \mathrm{~cm}^{2}\right)$ in a humidified atmosphere at $37{ }^{\circ} \mathrm{C}$ with $5 \% \mathrm{CO}_{2}$ (by volume). The cells were grown in F-10 Ham's medium (Gibco, Invitrogen) supplemented with $10 \%$ by volume fetal bovine serum (Gibco, Invitrogen) and $1 \%$ (by volume) of antibiotics solution (penicillin/streptomycin). Cultures were passaged every $24 \mathrm{~h}$ by a dilution factor of $1 / 2$. Confluent cells were detached with trypsin and suspended in fresh media. Cell suspension was counted using a Neubauer chamber and seeded in 12-well cell culture plate (TPP) at a density of $1.2 \times 10^{4}$ cells per well (at a concentration of $1 \times 10^{6}$ cells $/ \mathrm{mL}$ ). Substrates were incubated for $24 \mathrm{~h}$. Prepared substrates were immersed for $30 \mathrm{~min}$ in alcohol $70 \%$ to sterilize them before use in cell experiments. The flat surfaces were analysed based on the morphology of the cell attached to the surfaces by shape factor [1].

RESULTS: In the case of flat surfaces, $\mathrm{CHO}$ cell presented the best spreading on the SU-8 surface, followed by DLC (ta-C) surface, while PDMS was the worst situation, due to low wettability of this material. In the case of microstructured surfaces, SU-8 containing hexagonal microcavities of $12 \mu \mathrm{m}$ proved to be the most adverse situation to $\mathrm{CHO}$ cell growth, probably because of the steep topography with cavities size lower than the $\mathrm{CHO}$ cells size. Instead, SU-8 containing hexagonal microcavities of $80 \mu \mathrm{m}$ was the most favorable surface to $\mathrm{CHO}$ cell growth, even compared to reference glass. All surfaces were not cytotoxic.

DISCUSSION \& CONCLUSIONS: CHO cell presented optimized and controlled attachment to the SU-8 2005 surface by introduction of micro scale hexagonal cavities of $80 \mu \mathrm{m}$, with results comparable to the reference glass.

REFERENCES: ${ }^{1}$ A. K. Shah, R. K. sinha, N. J. Hickok, R. S. Tuan (1999) Bone, 24(5):499-506. 
Apêndice

Artigo publicado em revista indexada. 


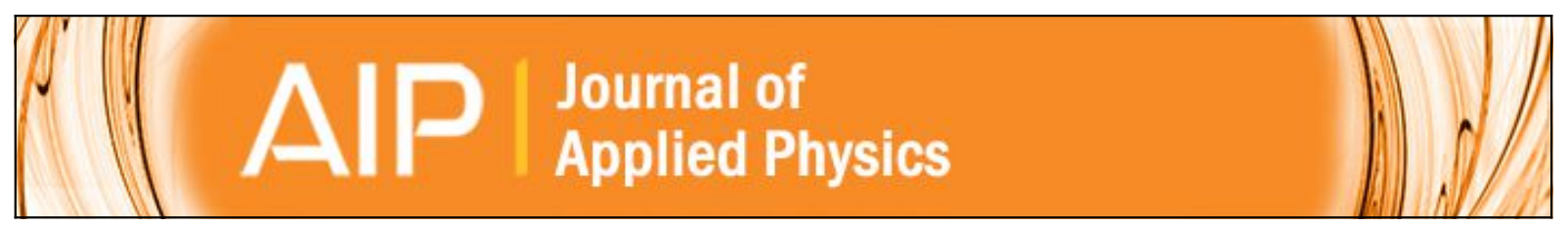

\section{Cell adhesion and growth on surfaces modified by plasma and ion implantation}

W. W. R. Araujo, F. S. Teixeira, G. N. da Silva, D. M. F. Salvadori, and M. C. Salvadori

Citation: Journal of Applied Physics 115, 154701 (2014); doi: 10.1063/1.4871541

View online: http://dx.doi.org/10.1063/1.4871541

View Table of Contents: http://scitation.aip.org/content/aip/journal/jap/115/15?ver=pdfcov

Published by the AIP Publishing

\section{Articles you may be interested in}

Epithelial cell morphology and adhesion on diamond films deposited and chemically modified by plasma processes

Biointerphases 9, 031012 (2014); 10.1116/1.4890471

Enhancement of hemocompatibility on titanium implant with titanium-doped diamond-like carbon film evaluated by cellular reactions using bone marrow cell cultures in vitro J. Vac. Sci. Technol. B 27, 1559 (2009); 10.1116/1.3077271

Development of a regeneration-type neural interface: A microtube guide for axon growth of neuronal cells fabricated using focused-ion-beam chemical vapor deposition J. Vac. Sci. Technol. B 24, 2538 (2006); 10.1116/1.2359730

Improved adhesion of amorphous carbon thin films on glass by plasma treatment J. Vac. Sci. Technol. A 22, 1297 (2004); 10.1116/1.1735867

Cell adhesion and spreading on polymer surfaces micropatterned by ion beams J. Vac. Sci. Technol. A 21, 1145 (2003); 10.1116/1.1575217

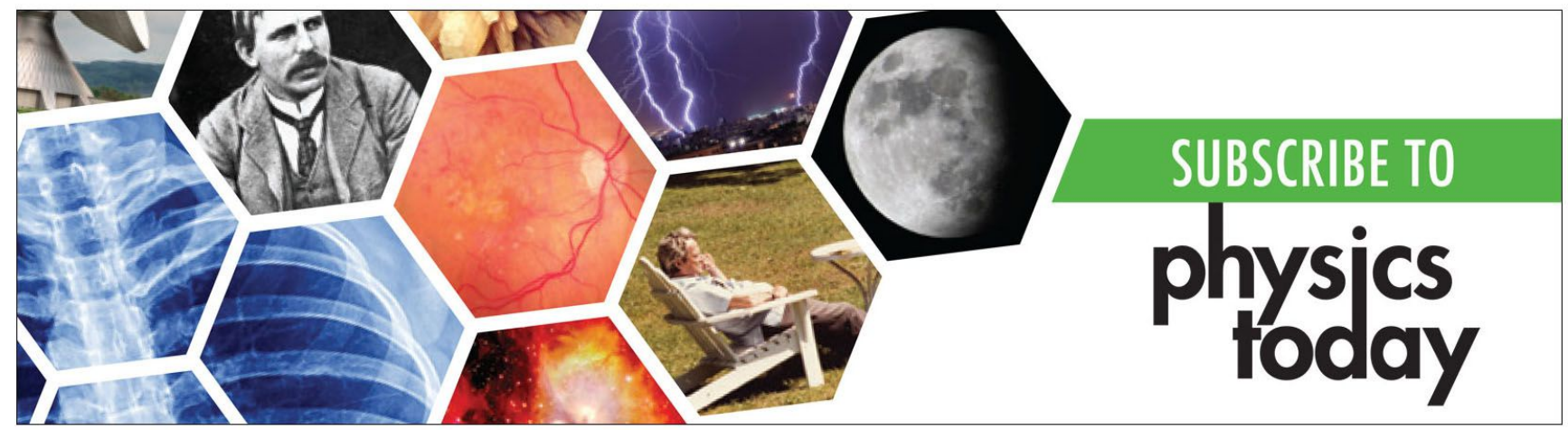




\title{
Cell adhesion and growth on surfaces modified by plasma and ion implantation
}

\author{
W. W. R. Araujo, ${ }^{1, a)}$ F. S. Teixeira, ${ }^{1}$ G. N. da Silva, ${ }^{2}$ D. M. F. Salvadori, ${ }^{3}$ and M. C. Salvadori ${ }^{1}$ \\ ${ }_{1}^{1}$ Institute of Physics, University of São Paulo, C.P. 66318, CEP 05315-970 São Paulo, Brazil \\ ${ }^{2}$ Clinical Analyses Department, Pharmacy School, Federal University of Ouro Preto, UFOP, Ouro Preto, \\ Minas Gerais, Brazil \\ ${ }^{3}$ Department Pathology, Faculty of Medicine, São Paulo State University, UNESP, São Paulo, Brazil
}

(Received 21 February 2014; accepted 4 April 2014; published online 15 April 2014)

\begin{abstract}
In this study, we show and discuss the results of the interaction of living CHO (Chinese Hamster Ovary) cells, in terms of adhesion and growth on glass, SU-8 (epoxi photoresist), PDMS (polydimethylsiloxane), and DLC (hydrogen free diamond-like carbon) surfaces. Glass, SU-8, and DLC but not PDMS showed to be good surfaces for cell growth. DLC surfaces were treated by oxygen plasma (DLC-O) and sulfur hexafluoride plasma (DLC-F). After $24 \mathrm{~h}$ of cell culture, the number of cells on DLC-O was higher than on DLC-F surface. SU-8 with silver implanted, creating nanoparticles $12 \mathrm{~nm}$ below the surface, increased significantly the number of cells per unit area. (C) 2014 AIP Publishing LLC. [http://dx.doi.org/10.1063/1.4871541]
\end{abstract}

\section{INTRODUCTION}

Surface modifications from organic ${ }^{1}$ to inorganic materials, ${ }^{2}$ have been widely used for cell growth, ${ }^{3-9}$ for a wide variety of applications, ranging from $\operatorname{cosmetics}^{10}$ to microelectronics industry. ${ }^{11}$ In this context, chemical treatments, including plasma surface modification, are commonly used, with considerable changes of surface properties, which influence the adhesion and proliferation of mammalian cells in a strong way. ${ }^{12}$ In the absence of cell surface ligands, the free surface energy is the main property correlated with cell adhesion. It is known that high surface energy promotes better cell adhesion and rapid cell spreading on the substrate, whereas low energy surfaces do not favor this type of behavior. $^{12}$

We evaluated four different pristine surfaces for cell adhesion and growth, namely, glass, SU-8 (epoxi photoresist), PDMS (polydimethylsiloxane), and DLC (hydrogen free diamond-like carbon). We also performed surface modification on DLC, using plasma treatment to form oxygen and fluorine terminations, and on SU-8, using silver ion implantation. This two modified surfaces were also evaluated concerning cell culture.

The choice of the materials was based on their properties and applications. SU-8 is an epoxi-based photo and electron beam resist used in a variety of applications, mainly using microfabrication techniques, such as microfluidics, superhydrophobicity, ${ }^{13-15}$ and bio-MEMS. ${ }^{16}$ Silver nanoparticles are known for their antibacterial properties. ${ }^{17}$ As it is known that implantation of metal into polymer using ion implantation forms nanoparticles inside the polymer, ${ }^{18-26}$ we evaluated the cell growth on buried silver nanoparticles into SU-8 formed by ion implantation. PDMS is a widely used polymeric material with several interesting characteristics, which include high flexibility, optical transparency,

\footnotetext{
a) Author to whom correspondence should be addressed. Electronic mail: wwlysses@if.usp.br. Tel.: +55 113091 6625. Fax: +55 1130916749.
}

biocompatibility, and ease to fabricate. ${ }^{27,28}$ Diamond-like carbon is an amorphous carbon material with high content of $\mathrm{sp}^{3}$ bonds, providing properties similar to diamond films, being also a biocompatible material.

The main objective of this study was to investigate the interaction of living cells, in terms of adhesion and growth, with these technologically interesting material surfaces.

\section{EXPERIMENTAL}

\section{A. Cell culture}

Chinese Hamster Ovary cells (CHO) in a freezing solution $(10 \%$ dimethyl sulfoxide (DMSO)) were stored in liquid nitrogen $\left(-195^{\circ} \mathrm{C}\right)$ in aliquots of $1 \times 10^{6}$ cells $/ \mathrm{ml}$ until be cultured. Then, cells were thawed and cultured in monolayers into culture flasks of $25 \mathrm{~cm}^{2}$ (Corning) in HAM- F10 medium (Invitrogen) supplemented with $10 \%$ fetal bovine serum (Cultilab) and antibiotics (streptomycin 1\% and penicillin $1 \%$ ). Cell cultures were incubated at $37^{\circ} \mathrm{C}$ and $5 \%$ $\mathrm{CO}_{2}$ until reach approximately $90 \%$ confluence. For subcultures, medium was removed and $5 \mathrm{ml}$ of Hanks $1 \mathrm{X}$ solution

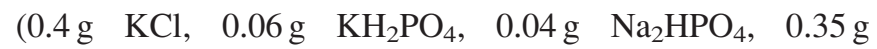
$\mathrm{NaHCO}_{3}, 1 \mathrm{~g}$ glucose, $8 \mathrm{~g} \mathrm{NaCl}, \mathrm{H}_{2} \mathrm{O}$ q.s.p. $1000 \mathrm{ml}$ ) were added for $2 \mathrm{~min}$. Afterwards, the Hanks solution was removed and $2 \mathrm{ml}$ of trypsin $0.25 \%$ /EDTA $1 \mathrm{X}$ (Invitrogen) were added for $5 \mathrm{~min}$, until cell detached. Subcultures were performed at 1:2 ratio, every $24 \mathrm{~h}$, in culture flasks of $25 \mathrm{~cm}^{2}$.

For evaluating cell growth and cell adhesion, each substrate was placed into a dish and then $1.2 \times 10^{5}$ exponentially growing cells were seeded (cultures in triplicate) and incubated for 24 h. $^{29,30}$ For cell adhesion, the criterion used was cells morphology. It is known that cells with spherical geometry present low adhesion to the substrate ${ }^{31}$ and high occurrence of this geometry means that the substrate is not favorable for cell growth. Thus, we define the form factor $F_{f}$ given by equation: ${ }^{31}$ 
TABLE I. Average form factor $\left(F_{f}\right)$, calculated by measuring 30 cells for each sample, and SFE for the selected substrates.

\begin{tabular}{lcc}
\hline \hline Sample & $F_{f}$ & SFE $(\mathrm{mN} / \mathrm{m})$ \\
\hline Glass & $0.50 \pm 0.03$ & $54 \pm 3$ \\
SU-8 & $0.52 \pm 0.03$ & $35 \pm 1$ \\
DLC & $0.54 \pm 0.03$ & $27 \pm 1$ \\
PDMS & $0.99 \pm 0.01$ & $9 \pm 1$ \\
\hline \hline
\end{tabular}

$$
F_{f}=4 \pi \frac{\text { area }}{(\text { perimeter })^{2}},
$$

where the area and perimeter of cells can be measured in an image of optical microscopy using software such as Image Pro from Media Cybernetics. The form factor $F_{f}$ can range from one (for a perfect circle) to almost zero (approximating a straight line, where the area would be almost zero). Thus, for elongated cells, $F_{f}$ will be low, while for the circular cells, representing low adhesion, $F_{f}$ will approach unity. In this way, we can numerically evaluate the cells adhesion to the substrate and the consequent suitability of the substrates for cell growth.

Initially, cell cultures were performed on substrates without pretreatment, i.e., without surface treatment. The substrates used were glass (cover slips from Glasstécnica), SU-8 (2005 from Micho Chem, resin used for electron beam lithography_electron resist), PDMS (from Dow Corning), and DLC on silicon, deposited by Metal Plasma Immersion Ion Implantation and Deposition (MePIIID). ${ }^{32}$ The evaluation of these cultures was performed calculating the cells form factors $\left(F_{f}\right)$.

Cell growth was proceeded on the modified surfaces and the number of live cells per unit area was performed for each substrate by optical microscopy. CHO cell viability after 24 $\mathrm{h}$ cell culture was performed using trypan blue exclusion methodology. Briefly, a freshly prepared solution of $500 \mu \mathrm{l}$ trypan blue $(0.05 \%)$ in distilled water was mixed to the same volume of fresh medium of culture. About 20-30 $\mu \mathrm{l}$ of this solution was placed on each substrate fully covering the surfaces that still contained attached cells. After $3 \mathrm{~min}$, optical microscopy images were acquired in five different regions of the surface. Dead cells were blue-stained. ${ }^{30}$

\section{B. Surface modification}

The materials used for surface modification were SU-8 and DLC. Silver ion implantation was performed in SU-8 substrates with dose of $1.2 \times 10^{16} \mathrm{~cm}^{-2}$ and energy of $8 \mathrm{keV}$. The implanter used has been described previously. ${ }^{33-35}$ Ion depth distribution inside SU-8 was simulated using the software Tridyn. ${ }^{36,37}$ The DLC samples were treated with oxygen plasma and with sulfur hexafluoride $\left(\mathrm{SF}_{6}\right)$ plasma, in separate samples, generating surfaces with oxygen terminations and fluorine terminations, respectively. ${ }^{38,39}$ The facility for plasma treatment has been described previously. ${ }^{40}$

\section{Contact angle and atomic force microscopy (AFM) imaging}

Contact angle was measured in a Goniometer KSV CAM 200 and the surface free energy (SFE) was evaluated using CAM SFE software with the method OWRK/Extended Fowkes. ${ }^{41}$ As liquid probes, we have used deionized water (18.2 M $\Omega$ cm, Millipore) and ethylene glycol (99.5\%, Merck).

AFM was used for imaging the SU-8 surface before and after the ion implantation. The microscope used was a NanoScope IIIA, from Bruker, in the intermittent contact mode. The tip radius used for the AFM image acquisition was $15 \mathrm{~nm}$ (nominal) and the cantilever resonant frequency was about $300 \mathrm{kHz}$.

\section{RESULTS AND DISCUSSION}

The form factors $\left(F_{f}\right)$ were calculated as an average value from measurements of 30 cells per image in 5 different regions for each sample. The results are listed in Table I, which shows that the samples of glass, SU-8, and DLC presented low values for the form factor, demonstrating a good cell spreading on these surfaces and consequent suitability of these substrates for cell growth. For the PDMS cells, the form factor obtained was the unit, attesting low cell spreading and consequent poor adhesion, indicating that PDMS was inadequate for cell growth. Considering these results, SU-8 and DLC were selected for surface modification.

The SFE was measured for all substrates and the results are also presented in Table I. The SFE obtained for PDMS is compatible with the form factor result, since low SFE promotes worst cell adhesion, ${ }^{12}$ generating cells with higher form factor. The SFE of the DLC and SU-8 have intermediate values compared with PDMS and glass, however, DLC and SU-8 present low form factor, suggesting good cell adhesion. Interestingly, despite of the significant difference between SFE of SU-8, DLC, and glass, the difference between their form factors were not so significant.

The results for DLC, DLC-O (treated by oxygen plasma), and DLC-F (treated with $\mathrm{SF}_{6}$ plasma) are shown in Figure 1, where the number of live cells per unit area is given for those three substrates, for three independent
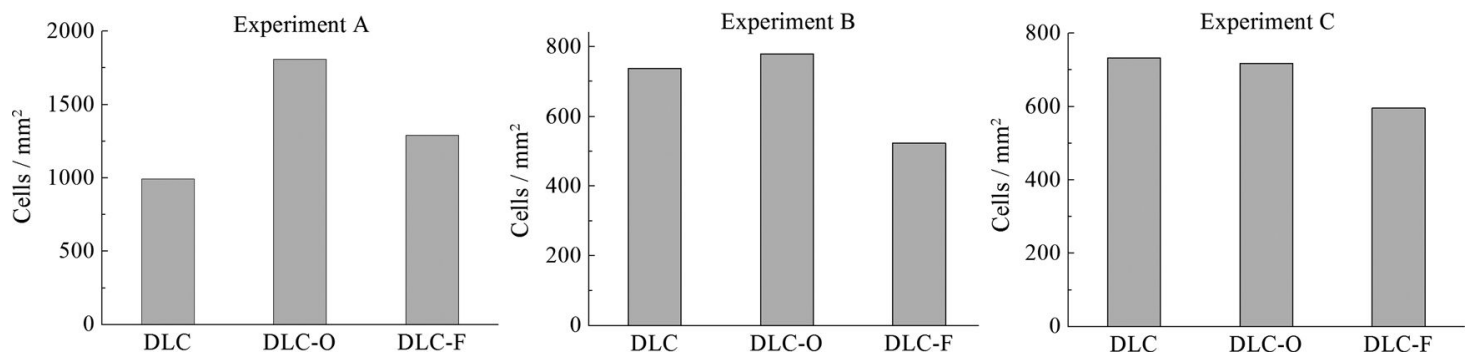

FIG. 1. Number of live cells per unit area for three substrates: DLC-O, DLC-F, and DLC without plasma treatment, for three independent experiments. 


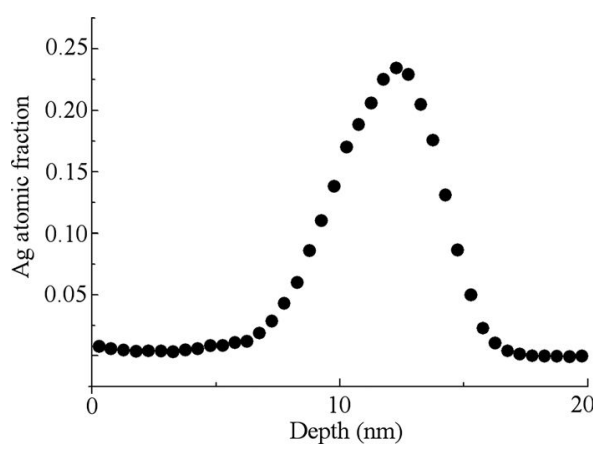

FIG. 2. Depth profile of Ag implanted in SU-8 for ion energy of $8 \mathrm{keV}$ and dose of $1.2 \times 10^{16} \mathrm{~cm}^{-2}$, as calculated by the TRIDYN simulation code. The maximum concentration of silver is located at approximately $12 \mathrm{~nm}$ below the surface.

experiments. The results, for all experiments, showed that the number of cells on the DLC-O was higher than on DLC-F. For better understanding this result, the wettability of the DLC-O and the DLC-F were evaluated by contact angle measurements. For the DLC-O, the contact angle obtained was $(63 \pm 2)^{\circ}(\mathrm{SFE}=39 \pm 1 \mathrm{mN} / \mathrm{m})$ and, for the DLC-F, was $(90 \pm 1)^{\circ}(\mathrm{SFE}=27 \pm 2 \mathrm{mN} / \mathrm{m})$, which is compatible with the literature results. ${ }^{42-44}$ These results agree with those previously reported by Duailibi et al. ${ }^{45}$ showing that hydrophilic surfaces benefit cell growth. Concerning to the DLC without plasma treatment, cell growth presented different behaviors for each of the three independent experiments. An explanation for that could be the possible randomness of chemical species present on the DLC surface without treatment, leading to non reproducible results.

Ion implantation was performed in SU-8 using silver (Ag) dose of $1.2 \times 10^{16} \mathrm{~cm}^{-2}$ (confirmed by Rutherford Backscattering Spectrometry-RBS) with energy of $8 \mathrm{keV}$. Figure 2 presents TRIDYN simulation, where the depth profile of Ag implanted in SU-8 is plotted. The maximum concentration of silver is located at approximately $12 \mathrm{~nm}$ below the surface, where the nanoparticles are formed. ${ }^{46}$
The result from cell culture in SU-8 with (SU-8/Ag) and without (SU-8) silver implantation is shown in Figure 3. The number of live and dead cells per unit area is given for both substrates, from three independent experiments. In all experiments, the number of cells on SU-8/Ag surface was higher than on original SU-8. Similarly, higher amount of dead cells was also detected on the SU-8/Ag surface. Nevertheless, considering that the number of dead cells was less than $1 \%$ of live cells per unit area, it is possible to conclude that the SU-8/Ag surface had better performance for cell growth.

The surface free energy of SU-8 was determined from contact angle measurements for the SU-8 $(35 \pm 1 \mathrm{mN} / \mathrm{m})$ and for the SU-8/Ag $(30 \pm 1 \mathrm{mN} / \mathrm{m})$. The difference between these values is too low for justifying the different cells behavior on these surfaces. Figure 4 presents AFM images of SU-8 surface with and without silver implantation. It is possible to observe that the implanted surface is nanostructured, but it is known ${ }^{47}$ that nano patterned surfaces can interfere with cell growth just when the structures have aspect ratio near unit, that is not this case, where the lateral size of the structures were in average $40 \mathrm{~nm}$ and the heights $5 \mathrm{~nm}$, giving an aspect ratio of 0.13 . Concerning to the surface area, the $\mathrm{SU}-8 / \mathrm{Ag}$ has $6.7 \%$ higher area than the original SU-8, which is compatible with the low aspect ratio of the structures. In this way, these nanostructures do not justify also the different cells behavior on the SU-8 and SU-8/Ag surfaces. A possible reason for the better performance for the cell growth on SU-8/Ag is the possibility of the cells access the silver nanoparticles $12 \mathrm{~nm}$ below the surface, generating benefits for the cells culture.

\section{SUMMARY AND CONCLUSION}

CHO cells were cultured on glass, SU-8, DLC, and PDMS surfaces and the criterion of form factor analysis was used for evaluating the suitability of the substrates for this purpose. Glass, SU-8, and DLC presented low values for the
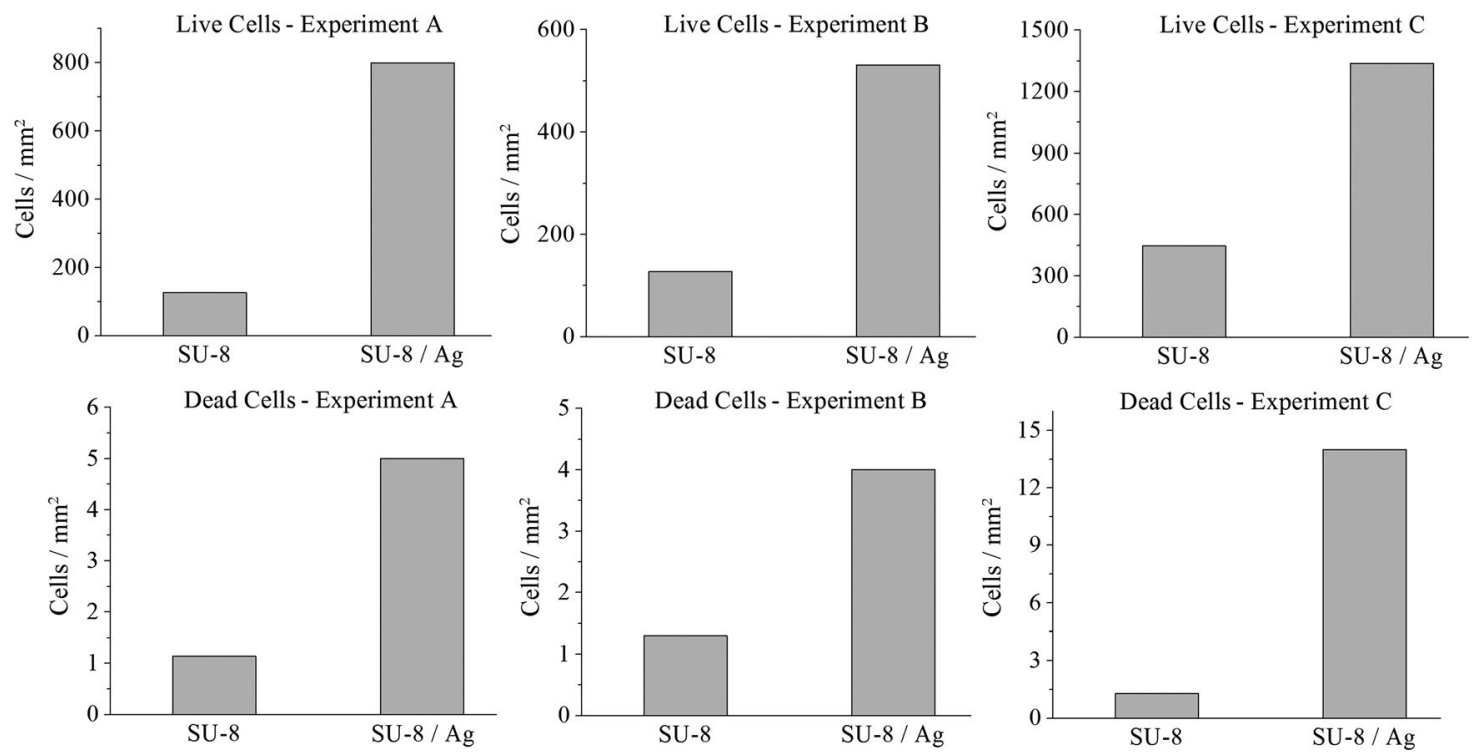

FIG. 3. Upper histograms: number of live cells per unit area for substrates of SU-8 with and without silver implantation, for three independent experiments. Lower histograms: number of dead cells per unit area for substrates of SU-8 with and without silver implantation, for three independent experiments. 

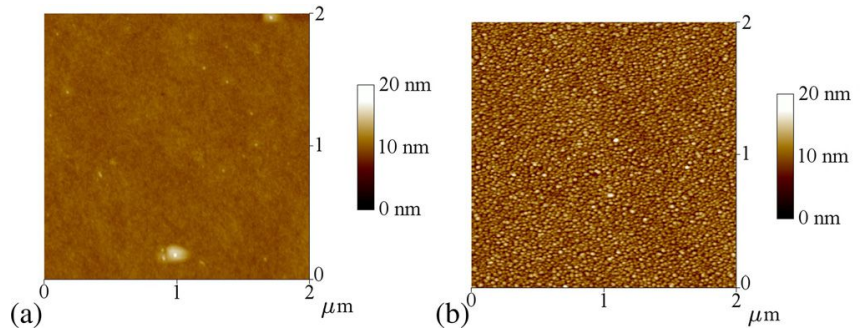

FIG. 4. AFM images of (a) original SU-8 and (b) SU-8 modified by Ag ion implantation.

form factor, demonstrating these materials are good for cell growth. For the PDMS surfaces, the form factor was the unit, indicating that PDMS is inadequate for cell growth.

DLC surfaces were treated by oxygen plasma (DLC-O) and sulfur hexafluoride plasma (DLC-F). CHO cells were cultured on DLC-O, DLC-F, and DLC without plasma treatment, and $24 \mathrm{~h}$ later, the number of cells on the DLC-O was higher than on DLC-F surface, what can be justified by the hydrophilicity of the DLC-O (contact angle of DLC-O was $(63 \pm 2)^{\circ}$ and of the DLC-F was $\left.(90 \pm 1)^{\circ}\right)$. The DLC without plasma treatment presented different behaviors on the cell growth for each of three independent experiments, possible because of the randomness of chemical species present on the DLC surface without treatment, leading to non reproducible results.

SU-8 with silver implanted, creating nanoparticles $12 \mathrm{~nm}$ below the surface, brought exciting new results in terms of increasing the number of cells for three independent experiments. The surface free energy of SU-8 with and without silver implantation is very similar, which does not justify the different cells behavior on these surfaces. AFM image of SU-8 with silver implantation shows nanostructures with aspect ratio of 0.13 that is too low for justifying the different cells behavior on the surfaces. A possible reason for the better performance for the cell growth on SU-8/Ag is the possibility of the cells access the silver nanoparticles $12 \mathrm{~nm}$ below the surface, generating benefits for the cells culture.

\section{ACKNOWLEDGMENTS}

This study was supported by the Fundação de Amparo a Pesquisa do Estado de São Paulo (FAPESP) and the Conselho Nacional de Desenvolvimento Científico e Tecnológico (CNPq), Brazil.

${ }^{1}$ S.-W. Lee, K. E. Tettey, I. L. Kim, J. A. Burdick, and D. Lee, Macromolecules 45, 6120 (2012).

${ }^{2}$ A. V. Singh, V. Vyas, R. Patil, V. Sharma, P. E. Scopelliti et al., PLoS One 6, e25029 (2011).

${ }^{3}$ A. V. Vashi, J. A. M. Ramshaw, V. Glattauer, C. M. Elvin, R. E. Lyons, and J. A. Werkmeister, Biofabrication 5, 035005 (2013).

${ }^{4}$ B. N. Lourenço, G. Marchioli, W. Song, R. L. Reis, C. A. van Blitterswijk, M. Karperien, A. van Apeldoorn, and J. F. Mano, Biointerphases 7, 46 (2012).

${ }^{5}$ G. Y. Park, S. J. Park, M. Y. Choi, I. G. Koo, J. H. Byun, J. W. Hong, J. Y. Sim, G. J. Collins, and J. K. Lee, Plasma Sources Sci. Technol. 21, 043001 (2012).

${ }^{6}$ A. Cifuentes and S. Borrós, Langmuir 29, 6645 (2013).

${ }^{7}$ M. G. Bellino, S. Golbert, M. C. De Marzi, G. J. A. A. Soler-Illia, and M. F. Desimone, Biomater. Sci. 1, 186 (2013).
${ }^{8}$ M. Schernthaner, B. Reisinger, H. Wolinski, S. D. Kohlwein, A. TrantinaYates, M. Fahrner, C. Romanin, H. Itani, D. Stifter, G. Leitinger, K. Groschner, and J. Heitz, Acta Biomater. 8, 2953 (2012).

${ }^{9}$ A. Ruiz, C. E. Flanagan, and K. S. Masters, J. Biomed. Mater. Res. Part A 101, 2870 (2013).

${ }^{10}$ B. Bhushan, W. Tang, and S. Ge, J. Microsc. 240, 135 (2010).

${ }^{11}$ A. Doerr, Nat. Methods 10, 818 (2013).

${ }^{12}$ S. A. Mitchell, N. Emmison, and A. G. Shard, Surf. Interface Anal. 33, 742 (2002).

${ }^{13}$ M. C. Salvadori, M. R. S. Oliveira, R. Spirin, F. S. Teixeira, M. Cattani, and I. G. Brown, J. Appl. Phys. 114, 174911 (2013).

${ }^{14}$ M. C. Salvadori, M. Cattani, M. R. S. Oliveira, F. S. Teixeira, and I. G. Brown, Appl. Phys. Lett. 96, 074101 (2010).

${ }^{15}$ M. C. Salvadori, M. Cattani, M. R. S. Oliveira, F. S. Teixeira, and I. G. Brown, J. Appl. Phys. 108, 024908 (2010).

${ }^{16}$ G. Perry, F. Lapierre, Y. Coffinier, V. Thomy, R. Boukherroub, C. Lu, S. H. Tsang, B. K. Tay, and P. Coquet, in Proceedings of the IEEE 5th International Nanoelectronics Conference (INEC) (2013), p. 374.

${ }^{17}$ J. R. Morones-Ramirez, J. A. Winkler, C. S. Spina, and J. J. Collins, Sci. Transl. Med. 5, 190ra81 (2013).

${ }^{18}$ M. C. Salvadori, M. Cattani, F. S. Teixeira, and I. G. Brown, Appl. Phys. Lett. 93, 073102 (2008).

${ }^{19}$ F. S. Teixeira, M. C. Salvadori, M. Cattani, and I. G. Brown, J. Appl. Phys. 105, 064313 (2009).

${ }^{20}$ F. S. Teixeira, M. C. Salvadori, M. Cattani, S. M. Carneiro, and I. G. Brown, J. Vac. Sci. Technol. B 27, 2242 (2009).

${ }^{21}$ F. S. Teixeira, M. C. Salvadori, M. Cattani, and I. G. Brown, J. Vac. Sci. Technol. A 28, 818 (2010).

${ }^{22}$ F. S. Teixeira, M. C. Salvadori, M. Cattani, and I. G. Brown, J. Appl. Phys. 106, 056106 (2009).

${ }^{23}$ F. S. Teixeira, M. C. Salvadori, M. Cattani, and I. G. Brown, J. Appl. Phys. 108, 093505 (2010).

${ }^{24}$ F. S. Teixeira, M. C. Salvadori, M. Cattani, and I. G. Brown, J. Appl. Phys. 111, 104311 (2012).

${ }^{25}$ M. C. Salvadori, F. S. Teixeira, M. Cattani, and I. G. Brown, J. Appl. Phys. 110, 114905 (2011).

${ }^{26}$ J. Ferreira, F. S. Teixeira, A. R. Zanatta, M. C. Salvadori, R. Gordon, and O. N. Oliveira Jr., Phys. Chem. Chem. Phys. 14, 2050 (2012).

${ }^{27}$ J. Zhang, Y. Chen, and M. A. Brook, Langmuir 29, 12432 (2013).

${ }^{28}$ K. Mogi and T. Fujii, Lab Chip 13, 1044 (2013).

${ }^{29}$ T. Sordel et al., Biomaterials 28, 1572 (2007).

${ }^{30}$ D. A. Ribeiro, M. E. A. Marques, and D. M. F. Salvadori, J. Mater. Sci.: Mater. Med. 17, 495 (2006).

${ }^{31}$ A. K. Shah, R. K. Sinha, N. J. Hickok, and R. S. Tuan, Bone 24, 499 (1999).

${ }^{32}$ M. C. Salvadori, F. S. Teixeira, W. W. R. Araujo, L. G. Sgubin, and I. G. Brown, Diamond Relat. Mater. 25, 8 (2012).

${ }^{33}$ M. C. Salvadori, F. S. Teixeira, L. G. Sgubin, W. W. R. Araujo, R. E. Spirin, M. Cattani, E. M. Oks, and I. G. Brown, Rev. Sci. Instrum. 85, 02B502 (2014).

${ }^{34}$ M. C. Salvadori, F. S. Teixeira, L. G. Sgubin, W. W. R. Araujo, R. E. Spirin, E. M. Oks, and I. G. Brown, Rev. Sci. Instrum. 84, 023506 (2013).

${ }^{35}$ M. C. Salvadori, F. S. Teixeira, L. G. Sgubin, W. W. R. Araujo, R. E. Spirin, E. M. Oks, K. M. Yu, and I. G. Brown, Appl. Phys. Lett. 101, 224104 (2012).

${ }^{36}$ W. Möller and W. Eckstein, Nucl. Instrum. Methods Phys. Res., Sect. B 2, 814 (1984).

${ }^{37}$ W. Möller, W. Eckstein, and J. P. Biersack, Comput. Phys. Commun. 51, 355 (1988).

${ }^{38}$ M. C. Salvadori, W. W. R. Araújo, F. S. Teixeira, M. Cattani, A. Pasquarelli, E. M. Oks, and I. G. Brown, Diamond Relat. Mater. 19, 324 (2010).

${ }^{39}$ W. W. R. Araujo, M. C. Salvadori, F. S. Teixeira, M. Cattani, and I. G. Brown, Microsc. Res. Tech. 75, 977 (2012).

${ }^{40}$ A. Vizir, E. M. Oks, M. C. Salvadori, F. S. Teixeira, and I. G. Brown, Rev. Sci. Instrum. 78, 086103 (2007).

${ }^{41}$ D. K. Owens and R. C. Wendt, J. Appl. Polym. Sci. 13, 1741 (1969).

${ }^{42}$ S. C. H. Kwok et al., Diamond Relat. Mater. 14, 78 (2005).

${ }^{43}$ M. Shinohara et al., IEEE Trans. Plasma Sci. 40, 2756 (2012).

${ }^{44}$ M. Schvartzman and S. J. Wind, Nanotechnology 20, 145306 (2009).

${ }^{45}$ S. E. Duailibi, M. T. Duailibi, L. M. Ferreira, K. I. L. C. Salmazi, M. C. Salvadori, F. S. Teixeira, A. Pasquarelli, J. P. Vacanti, and P. C. Yelick, Tissue Eng. 19, 2537 (2013).

${ }^{46}$ A. L. Stepanov, D. E. Hole, and P. D. Townsend, J. Non-Cryst. Solids 260, 65 (1999).

${ }^{47}$ S. H. Chung, S. J. Son, and J. Min, Nanotechnology 21, 125104 (2010). 


\section{Referências Bibliográficas}

[1] SALVADORI, M. C.; OLIVEIRA, M. R. S.; SPIRIN, R.; TEIXEIRA, F. S.; CATTANI, M.; BROWN, I. G. Microcavity-array superhydrophobic surfaces: Limits of the model. $J$. Appl. Phy., v. 114, p. 174911, (2013).

[2] SALVADORI, M. C.; CATTANI, M.; OLIVEIRA, M. R. S.; TEIXEIRA, F. S.; BROWN, I. G. Design and fabrication of superhydrophobic surfaces formed of microcavities. Appl. Phy. Lett., v. 96, p. 074101, (2010).

[3] SALVADORI, M. C.; CATTANI, M.; OLIVEIRA, M. R. S.; TEIXEIRA, F. S.; BROWN, I. G. Design and fabrication of microcavity-array superhydrophobic surfaces. J. Appl. Phys., v. 108, p. 024908, (2010).

[4] ARAÚJO, W.; SALVADORI, M. C.; TEIXEIRA, F. S.; CATTANI, M.; BROWN, I. G. On environmental effects in kelvin force microscopy of modified diamond surfaces. Microscopy Research and Technique, v. 75, p. 977 981, (2012).

[5] SALVADORI, M. C.; ARAÚJO, W.; TEIXEIRA, F. S.; CATTANI, M.; PASQUARELLI, A.; OKS, E. M.; BROWN, I. G. Termination of diamond surfaces with hydrogen, oxygen and fluorine using a small, simple plasma gun. Diamond and Related Materials, v. 19, p. 324 328, (2010).

[6] ARAÚJO, W. W. R.; TEIXEIRA, F. S.; SILVA, G. N. da; SALVADORI, D. M. F.; SALVADORI, M. C. Cell adhesion and growth on surfaces modified by plasma and ion implantation. Journal of Applied Physics, v. 115, p. 154701, (2014).

[7] DUAILIBI, S. E.; DUAILIBI, M. T.; FERREIRA, L. M.; SALMAZI, K. I. L. C.; SALVADORI, M. C.; TEIXEIRA, F. S.; PASQUARELLI, A.; VACANTI, J. P.; YELICK, P. C. Tooth tissue engineering: the influence of hydrophilic surface on nanocrystalline diamond films for human dental stem cells. Tissue Eng., v. 19, n. (23-24), p. 253743, (2013).

[8] ROSS, A. M.; JIANG, Z.; BASTMEYER, M.; LAHANN, J. Physical aspects of cell culture substrates: Topography, roughness, and elasticity. Small, v. 8, n. 3, p. 336 355, (2011).

[9] KULISCH, W.; POPOV, C.; GILLILAND, D.; CECCONE, G.; SIRGHI, L.; RUIZ, A.; ROSSI, F. Surface properties of differently prepared ultrananocrystalline diamond surfaces. Diamond and Related Materials, v. 18, p. 745 749, (2009). 
[10] CRAIGHEAD, H. G.; TURNER, S. W.; DAVIS, R. C.; JAMES, C.; PERES, A. M.; JOHN, P. M. S.; ISAACSON, M. S.; KAM, L.; SHAIN, W.; TURNER, J. N.; BANKER, G. Chemical and topographical surface modification for control of central nervous system cell adhesion. Biomedical Microdevices, v. 1, n. 1, p. 49 64, (1998).

[11] PLACE, E. S.; GEORGE, J. H.; WILLIAMS, C. K. et al. Synthetic polymer scaffolds for tissue engineering. Chemical Society Reviews, v. 38, n. 4, p. 1139 1151, (2009).

[12] WANG, Z. X.; MA, L. N. Gold nanoparticle probes. Coordination Chemistry Reviews, v. 253, p. 1607 1618, (2009).

[13] VARIOLA, F.; VETRONE, F.; RICHERT, L. et al. Improving biocompatibitity of implantable metals by nanoscale modification of surfaces: An overview of strategies, fabrication methods, and challenges. Small, v. 5, p. 996 1006, (2009).

[14] CHOI, L.; PARK, H. K.; CHUN, H. J. et al. Collagen modified polystyrene plate for enhanced cell cultivation. Tissue Engeneering and Regenerative Medicine, v. 6, p. 432 437, (2009).

[15] SVORCIK, V.; KASALKOVA, N.; SLEPICKA, P. et al. Cytocompatibility of ar+ plasma treated and au nanoparticle-grafted pe. Nuclear Instruments \& Methods in Physics Research Section B-Beam Interactions With Materials and Atoms, v. 267, p. 1904 1910, (2009).

[16] ONO, T.; AKAGI, T.; ICHIKI, T. et al. Hydrophilization of amorphous perfluoropolymer using low-pressure argon plasma. Journal of Photopolymer Science and Technology, v. 22, p. 683 689, (2009).

[17] KAKADE, B. A. Chemical control of superhydrophobicity of carbon nanotube surfaces: droplet pinning and electrowetting behavior. Nanoscale, v. 5, n. 15, p. 7011 7016, (2013).

[18] MARTINI, D.; MARTI, O.; BEIL, M.; PAUST, T.; HUANG, C.; MOOSMANN, M.; JIN, J.; HEILER, T.; GRöGER, R.; SCHIMMEL, T. Interaction of epithelial cells with surfaces and surfaces decorated by molecules. Advances in Nanotechnology, v. 69, p. 151 190, (2013).

[19] MENG, L.-Y.; PARK, S.-J. Improvement of superhydrophobicity of multi-walled carbon nanotubes produced by fluorination. Carbon Letters, v. 13, n. 3, p. 178 181, (2012).

[20] LEE, S. W.; TETTEY, K. E.; KIM, I. L.; BURDICK, J. A.; LEE, D. Controlling the cell-adhesion properties of poly(acrylic acid)/polyacrylamide hydrogen-bonded multilayers. Macromolecules, v. 45, p. 6120 6126, (2012).

[21] XING, M.; ZHONG, W.; XU, X.; THOMSON, D. Adhesion force studies of nanofibers and nanoparticles. Langmuir, v. 26, n. 14, p. 11809 11814, (2010).

[22] HYND, M. R.; FRAMPTON, J. P.; MESFIN, N. D.; TURNER, J. N.; SHAIN, W. Directed cell growth on protein-functionalized hydrogel surfaces. Journal of neuroscience methods, v. 162, n. 1-2, p. 255 263, (2007).

[23] CANTIN, S.; BOUTEAU, M.; BENHABIB, F.; PERROT, F. Surface free energy evaluation of well-ordered langmuir-blodgett surfaces: Comparison of different approaches. Colloids and Surfaces A: Physicochemical and Engineering Aspects, v. 276, n. 1-3, p. 107 115, (2006). 
[24] CHEN, X.; TAM, U. C.; CZLAPINSKI, J. L.; LEE, G. S.; RABUKA, D.; ZETTL, A.; BERTOZZI, C. R. Interfacing carbon nanotubes with living cells. J. AM. CHEM. SOC., v. 128, n. 19, p. 6292 6293, (2006).

[25] SILVA, M. N. D.; DESAI, R.; ODDE, D. J. Micro-patterning of animal cells on pdms substrates in the presence of serum without use of adhesion inhibitors. Biomedical Microdevices, v. 6, n. 3, p. 219 222, (2004).

[26] RODEN, E. E.; ZACHARA, J. M. Microbial reduction of crystalline iron(iii) oxides: Influence of oxide surface area and potential for cell growth. US Department of Energy Publications, p. Paper 214, (1996).

[27] KOBAYASHI, S.; MAKINO, E.; MINETA, T.; KOMATSUZAKI, T. Effects of microstructure geometry and plasma modification on wetting properties of su- 8 surfaces. Microelectronic Engineering, v. 88, n. 8, p. 1775 1778, (2011).

[28] PASHKULEVA, I.; MARQUES, A. P.; VAZ, F.; REIS, R. L. et al. Surface modification of starch based biomaterials by oxygen plasma or uv-irradiation. J Mater Sci: Mater Med, v. 21, p. 2132 , (2010).

[29] YAMADA, N.; NAKAMATSU, K.-i.; KANDA, K.; HARUYAMA, Y.; MATSUI, S. Surface evaluation of fluorinated diamond-like carbon thin film as an antisticking layer of nanoimprint mold. Japanese Journal of Applied Physics, The Japan Society of Applied Physics, v. 46, n. 9B, p. 6373 6374, (2007).

[30] TAVARES, J. C. M.; CORNéLIO, D. A.; SILVA, N. B.; MOURA, C. E. B.; QUEIROZ, J. D. F.; Sá, J. C.; JUNIOR, C. A.; MEDEIROS, S. R. B. Effect of titanium surface modified by plasma energy source on genotoxic response in vitro. Toxicology, v. 262, n. 2, p. 138 145, (2009).

[31] SORDEL, T.; KERMAREC-MARCEL, F.; GARNIER-RAVEAUD, S.; GLADE, N.; SAUTER-STARACE, F.; PUDDA, C.; BORELLA, M.; PLISSONNIER, M.; CHATELAIN, F.; BRUCKERT, F. Influence of glass and polymer coatings on cho cell morphology and adhesion. Biomaterials, Elsevier BV, v. 28, n. 8, p. 1572 1584, (2007).

[32] RISTEIN, J. Surface science of diamond: Familiar and amazing. Surface Science, v. 600, n. 18, p. 3677 3689, (2006). Berlin, Germany: 4-9 September 2005, Proceedings of the 23th European Conference on Surface Science.

[33] REZEK, B.; NEBEL, C. E. Kelvin force microscopy on diamond surfaces and devices. Diamond and Related Materials, v. 14 (3-7), p. 466 469, March-July (2005).

[34] YU, G. Q.; TAY, B. K.; SUN, Z.; PAN, L. K. Properties of fluorinated amorphous diamond like carbon films by pecvd. Applied Surface Science, v. 219, n. 3-4, p. 228237 , (2003).

[35] TACHIKI, M.; SUMIKAWA, Y.; SHIGENO, M.; BANNO, T.; SONG, K. S.; UMEZAWA, H.; KAWARADA, H. Diamond nanofabrication and characterization for biosensing application. Physica Status Solidi (a), v. 199, n. 1, p. 39 43, (2003).

[36] OSTROVSKAYA, L.; PEREVERTAILO, V.; RALCHENKO, V.; DEMENTJEV, A.; LOGINOVA, O. Wettability and surface energy of oxidized and hydrogen plasma-treated diamond films. Diamond and Related Material, v. 11(3-6), p. 845 850, March-June (2002). 
[37] KAIBARA, Y.; SUGATA, K.; TACHIKI, M.; UMEZAWA, H.; KAWARADA, H. Control wettability of the hydrogen-terminated diamond surface and the oxidized diamond surface using an atomic force microscope. Diamond and Related Material, v. 12(3-7), p. 560564 , March-July (2003).

[38] SUH, J.-D.; LIM, K. T.; JIN, H.; KIM, J.; CHOUNG, P.-H.; CHUNG, J. H. Effects of co-culture of dental pulp stem cells and periodontal ligament stem cells on assembled dual disc scaffolds. Tissue Engineering and Regenerative Medicine, v. 11, n. 1, p. 47 58, (2014).

[39] MILOVAC, D.; GAMBOA-MARTíNEZ, T. C.; IVANKOVIC, M.; FERRER, G. G.; IVANKOVIC, H. Pcl-coated hydroxyapatite scaffold derived from cuttlefish bone: In vitro cell culture studies. Materials Science and Engineering: C, v. 42, n. 1, p. 264 272, (2014).

[40] HERSEL, U.; DAHMEN, C.; KESSLER, H. Rgd modified polymers: biomaterials for stimulated cell adhesion and beyond. Biomaterials, v. 24, n. 24, p. 4385 4415, (2003).

[41] ZHOU, Z.; DAI, Y.; LIU, B.-b.; XIA, L.-1.; LIU, H.-b.; VADGAMA, P.; LIU, H.-r. Surface modification of titanium plate enhanced fibronectin-mediated adhesion and proliferation of mg-63 cells. Trans. Nonferrous Met. Soc. China, v. 24, p. 1065 1071, (2014).

[42] ZHAO, Q.; LIU, Y.; WANG, C.; WANG, S.; PENG, N.; JEYNES, C. Reduction of bacterial adhesion on ion-implanted stainless steel surfaces. Medical Engineering \& Physics, v. 30, p. $341349,(2008)$.

[43] ZHAO, Q.; LIU, Y.; WANG, C.; WANG, S.; PENG, N.; JEYNES, C. Bacterial adhesion on ion-implanted stainless steel surfaces. Applied Surface Science, v. 253, p. 86748681 , (2007).

[44] OZAWA, S.; KASUGAI, S. Evaluation of implant materials (hydroxyapatite, glassceramics, titanium) in rat bone marrow stromal cell culture. Biomaterials, v. 17, n. 1, p. 2329 , (1996).

[45] DELIGIANNI, D. D.; KATSALA, N. D.; KOUTSOUKOS, P. G.; MISSIRLIS, Y. F. Effect of surface roughness of hydroxyapatite on human bone marrow cell adhesion, proliferation, differentiation and detachment strength. Biomaterials, v. 22, n. 1, p. 87 96, (2000).

[46] VILLA, M. M.; WANG, L.; HUANG, J.; ROWE, D. W.; WEI, M. Bone tissue engineering with a collagen - hydroxyapatite scaffold and culture expanded bone marrow stromal cells. $J$ Biomed Mater Res Part B, v. 00B:000 - 000, p. 1 11, (2014).

[47] KOLOS, E. C.; RUYS, A. J. Osteoblast attachment to hydroxyapatite micro-tube scaffolds. Journal of Materials Science: Materials in Medicine, v. 25, n. 7, p. 18011817 , (2014).

[48] TIBBITT, M. W.; ANSETH, K. S. Hydrogels as extracellular matrix mimics for 3d cell culture. Biotechnology and Bioengineering, v. 103, n. 4, p. 655 663, (2009).

[49] MCKINNON, D. D.; DOMAILLE, D. W.; CHA, J. N.; ANSETH, K. S. Biophysically defined and cytocompatible covalently adaptable networks as viscoelastic $3 \mathrm{~d}$ cell culture systems. Adv. Mater., v. 26, n. 6, p. 865 872, (2013). 
[50] SIMON, K. A.; PARK, K. M.; MOSADEGH, B.; SUBRAMANIAM, A. B.; MAZZEO, A. D.; NGO, P. M.; WHITESIDES, G. M. Polymer-based mesh as supports for multi-layered 3d cell culture and assays. Biomaterials, v. 35, n. 1, p. 259 268, (2014).

[51] KAMIMURA, W.; KOYAMA, H.; MIYATA, T.; TAKATO, T. Sugar-based crosslinker forms a stable atelocollagen hydrogel that is a favorable microenvironment for $3 \mathrm{~d}$ cell culture. Journal of Biomedical Materials Research Part A, (2014).

[52] BHUSHAN, B.; TANG, W.; GE, S. et al. Nanomechanical characterization of skin and skin cream. Journal of Microscopy, v. 240 Pt 2, p. 135 144, (2010).

[53] MURPHY, S. V.; ATALA, A. 3d bioprinting of tissues and organs. Nat Biotech, v. 2958, p. 1 13, (2014).

[54] INZANA, J. A.; OLVERA, D.; FULLER, S. M.; KELLY, J. P.; GRAEVE, O. A.; SCHWARZ, E. M.; KATES, S. L.; AWAD, H. A. 3d printing of composite calcium phosphate and collagen scaffolds for bone regeneration. Biomaterials, v. 35, n. 13, p. 4026 4034, (2014).

[55] MATSUSAKI, M.; SAKAUE, K.; KADOWAKI, K.; AKASHI, M. Three-dimensional human tissue chips fabricated by rapid and automatic inkjet cell printing. Advanced Healthcare Materials, v. 2, n. 4, p. 534 539, (2013).

[56] ZHAO, L.; LEE, V. K.; YOO, S.-S.; DAI, G.; INTES, X. The integration of 3-d cell printing and mesoscopic fluorescence molecular tomography of vascular constructs within thick hydrogel scaffolds. Biomaterials, v. 33, n. 21, p. 5325 5332, (2012).

[57] FERRIS, C. J.; GILMORE, K. J.; BEIRNE, S.; MCCALLUM, D.; WALLACE, G. G.; PANHUIS, M. in het. Bio-ink for on-demand printing of living cells. Biomaterials Science, v. 1, n. 2, p. 224, 92013).

[58] GUILLOTIN, B.; GUILLEMOT, F. Cell patterning technologies for organotypic tissue fabrication. Trends in Biotechnology, v. 29, n. 4, p. 183 190, (2011).

[59] MIRONOV, V.; VISCONTI, R. P.; KASYANOV, V.; FORGACS, G.; DRAKE, C. J.; MARKWALD, R. R. Organ printing: Tissue spheroids as building blocks. Biomaterials, v. 30, n. 12, p. 2164 2174, (2009).

[60] DAHLin, C.; JOHANSSON, A.; HOFFMAN, M.; MOLENBERG, A. Early biocompatibility of poly (ethylene glycol) hydrogel barrier materials for guided bone regeneration. an in vitro study using human gingival fibroblasts (hgf-1). Clinical Oral Implants Research, v. 25, n. 1, p. 16 20, (2014).

[61] DJAFARZADEH, R.; CONRAD, C.; NOTOHAMIPRODJO, S.; HIPP, S.; NIESS, H.; BRUNS, C. J.; NELSON, P. J. Cell surface engineering using glycosylphosphatidylinositol anchored tissue inhibitor of matrix metalloproteinase-1 stimulates cutaneous wound healing. Wound Repair and Regeneration, v. 22, n. 1, p. 70 76, (2014).

[62] LARANJEIRA, M. S.; CARVALHO, A.; PELAEZ-VARGAS, A.; HANSFORD, D.; FERRAZ, M. P.; COIMBRA, S.; COSTA, E.; SANTOS-SILVA, A.; FERNANDES, M. H.; MONTEIRO, F. J. Modulation of human dermal microvascular endothelial cell and human gingival fibroblast behavior by micropatterned silica coating surfaces for zirconia dental implant applications. Sci. Technol. Adv. Mater., v. 15, n. 2, p. 025001, (2014). 
[63] ZHAO, B.; MEI, H. C. van der; SUBBIAHDOSS, G.; VRIES, J.; RUSTEMA-ABBING, M.; KUIJER, R.; BUSSCHER, H. J.; REN, Y. Soft tissue integration versus early biofilm formation on different dental implant materials. Dental Materials, v. 30, n. 7, p. 716727 , (2014).

[64] ANSELME, K. Osteoblast adhesion on biomaterials. Biomaterials, v. 21, n. 7, p. 667 $681,(2000)$.

[65] ALTUNA, A.; BELliSTRI, E.; CID, E.; AIVAR, P.; GAL, B.; BERGANZO, J.; GABRIEL, G.; GUIMERA, A.; VILLA, R.; FERNANDEZ, L. J.; Menendez de la Prida, L. Su-8 based microprobes for simultaneous neural depth recording and drug delivery in the brain. Lab Chip, v. 13, p. 1422 1430, (2013).

[66] EL-ALI, J.; SORGER, P. K.; JENSEN, K. F. Cells on chips. Nature, v. 442, n. 7101, p. 403 411, (2006).

[67] CAMPO, A. del; GREINER, C. Su-8: a photoresist for high-aspect-ratio and 3d submicron lithography. Journal of Micromechanics and Microengineering, v. 17, n. 6, p. R81 R95, (2007).

[68] CHO, S. H.; LU, H. M.; CAULLER, L.; ORTEGA, M. I. R.; LEE, J.; HUGHES, G. A. et al. Biocompatible su-8-based microprobes for recording neural spike signals from regenerated peripheral nerve fibers. IEEE Sensors Journal, v. 8, n. 11, p. 1830 1836, (2008).

[69] ARSCOTT, S. Su-8 as a material for lab-on-a-chip-based mass spectrometry. Lab on a Chip, Royal Society of Chemistry (RSC), (2014).

[70] MORONES-RAMIREZ, J. R.; WINKLER, J. A.; SPINA, C. S.; COLLINS, J. J. Silver enhances antibiotic activity against gram-negative bacteria. Science Translational Medicine, v. 5, n. 190, p. 190ra81 190ra81, (2013).

[71] GONG, X.; WEN, W. et al. Polydimethylsiloxane-based conducting composites and their applications in microfluidic chip fabrication. Biomicrofluidics, v. 3, p. 012007, (2009).

[72] FERREIRA, J.; TEIXEIRA, F. S.; ZANATTA, A. R.; SALVADORI, M. C.; GORDON, R.; OLIVEIRA, O. N. Tailored sers substrates obtained with cathodic arc plasma ion implantation of gold nanoparticles into a polymer matrix. Phys. Chem. Chem. Phys., Royal Society of Chemistry (RSC), v. 14, n. 6, p. 2050, (2012). Disponível em: $<$ http://dx.doi.org/10.1039/c2cp23287a $>$.

[73] TEIXEIRA, F. S.; SALVADORI, M. C.; CATTANI, M.; BROWN, I. G. Annealing effects on nanostructured gold-polymethylmethacrylate composites: Small-angle X-ray scattering analysis. J. Appl. Phys., AIP Publishing, v. 111, n. 10, p. 104311, (2012). Disponível em: $<$ http://dx.doi.org/10.1063/1.4720464>.

[74] SAlVADORI, M. C.; TEIXEIRA, F. S.; CATTANI, M.; BROWN, I. G. Electrical conductivity of platinum-implanted polymethylmethacrylate nanocomposite. J. Appl. Phys., AIP Publishing, v. 110, n. 11, p. 114905, (2011). Disponível em: $<$ http://dx.doi.org/10.1063/1.3668096>. 
[75] TEIXEIRA, F. S.; SALVADORI, M. C.; CATTANI, M.; BROWN, I. G. Electrical, optical, and structural studies of shallow-buried au-polymethylmethacrylate composite films formed by very low energy ion implantation. Journal of Vacuum Science \& Technology A: Vacuum, Surfaces, and Films, American Vacuum Society, v. 28, n. 4, p. 818, (2010). Disponível em: <http://dx.doi.org/10.1116/1.3357287>.

[76] TEIXEIRA, F. S.; SALVADORI, M. C.; CATTANI, M.; BROWN, I. G. Structural properties of buried conducting layers formed by very low energy ion implantation of gold into polymer. J. Appl. Phys., AIP Publishing, v. 106, n. 5, p. 056106, (2009). Disponível em: $<$ http://dx.doi.org/10.1063/1.3212574>.

[77] TEIXEIRA, F. S.; SALVADORI, M. C.; CATTANI, M.; CARNEIRO, S. M.; BROWN, I. G. Surface plasmon resonance of gold nanoparticles formed by cathodic arc plasma ion implantation into polymer. Journal of Vacuum Science \& Technology B: Microelectronics and Nanometer Structures, American Vacuum Society, v. 27, n. 5, p. 2242, (2009). Disponível em: $<$ http://dx.doi.org/10.1116/1.3231449>.

[78] TEIXEIRA, F. S.; SALVADORI, M. C.; CATTANI, M.; BROWN, I. G. Gold-implanted shallow conducting layers in polymethylmethacrylate. J. Appl. Phys., AIP Publishing, v. 105, n. 6, p. 064313, (2009). Disponível em: < http://dx.doi.org/10.1063/1.3088874>.

[79] SALVADORI, M. C.; CATTANI, M.; TEIXEIRA, F. S.; BROWN, I. G. Conducting polymer formed by low energy gold ion implantation. Applied Physics Letters, AIP Publishing, v. 93, n. 7, p. 073102, (2008). Disponível em: < http://dx.doi.org/10.1063/1.2973161>.

[80] ZHANG, J.; CHEN, Y.; BROOK, M. A. Facile functionalization of pdms elastomer surfaces using thiol-ene click chemistry. Langmuir, v. 29, n. 40, p. 12432 2442, (2013).

[81] MOGI, K.; FUJII, T. A novel assembly technique with semi-automatic alignment for pdms substrates. Lab on a Chip, Royal Society of Chemistry (RSC), v. 13, n. 6, p. 1044, (2013).

[82] LEWPIRIYAWONG, N. Conducting $\{P D M S\}$ for cell manipulation. $\{$ SciVee $\}$, Inc. Disponível em: <http://dx.doi.org/10.4016/26400.01>.

[83] HAUERT, R.; K., T.; G., T. et al. An overview on diamond-like carbon coatings in medical applications. Surface and Coatings Technology, v. 233, n. 25, p. 119 130, (2013).

[84] HAUERT, R. et al. A review of modified dlc coatings for biological applications. Diamond and Related Materials, v. 12, p. 583 589, (2003).

[85] TIAINEN, V.-M. Amorphous carbon as a bio-mechanical coating-mechanical properties and biological applications. Diamond and Related Materials, v. 10, p. 153 160, (2001).

[86] MITCHELL, B. S. An introduction to materials engineering and science: for chemical and materials engineers. [S.1.]: John Wiley \& Sons, Inc., (2004).

[87] CARREL, A.; MT, B. Cultivation of tissues in vitro and its technique. J Exp Med, v. 13, n. 3, p. 387 396, (1911).

[88] CARREL, A.; INGEBRIGTSEN, R. The production of antibodies by tissues living outside of the organism. J Exp Med., v. 15, n. 3, p. 287 291, (1912). 
[89] FOOT, N. C. The growth of chicken bone marrow in vitro and its bearing on hematogenesis in adult life. J Exp Med, v. 17, n. 1, p. 43 60, (1913).

[90] EBELING, A. H. The effect of the variation in the osmotic tension and of the dilution of culture media on the cell proliferation of connective tissue. J Exp Med, v. 20, n. 2, p. 130139 , (1914).

[91] EAGLE, H. The specific amino acid requirements of a human carcinoma cell (strain hela) in tissue culture. $J$ Exp Med, v. 102, n. 1, p. 37 48, (1955).

[92] OYAMA, V. I.; EAGLE, H. Measurement of cell growth in tissue culture with a phenol reagent (folin-ciocalteau). Exp Biol Med, v. 91, n. 2, p. 305 307, (1956).

[93] EAGLE, H.; OYAMA, V. I.; LEVY, M.; HORTON, C. L.; FLEISCHMAN, R. The growth response of mammalian cells in tissue culture to l-glutamine and l-glutamic acid. $J$. Biol. Chem, v. 218, n. 2, p. 607 616, (1956).

[94] PIEZ, K.; OYAMA, V. I.; LEVINTOW, L.; EAGLE, H. Proteolysis in stored serum and its possible significance in cell culture. Nature, v. 188, p. 59 60, (1960).

[95] ALBERTS, B.; BRAY, D.; LEWIS, J.; RAFF, M.; ROBERTS, K.; WATSON, J. Biologia Molecular da Célula. 3a. ed. [S.1.]: Editora Artes Médicas, (1997).

[96] FRESHNEY, R. I. Culture of Animal Cells: A Manual of Basic Technique and Specialized Applications. [S.1.]: John Wiley \& Sons, (2010).

[97] PORTNER, R. Animal Cell Biotechnology: Methods and Protocols. 2 nd. ed. [S.1.]: Humana Press Inc, (2007).

[98] DOYLE, A.; GRIFFITHS, J. B. The cell: Selection and standardization. [S.1.]: John Wiley \& Sons, (1998).

[99] GRIFFITHS, J. Cell Biology: Experimental Aspects. 1. ed. [S.1.]: Academic Press., (1984).

[100]MASTERS, J. R. W. Animal cell culture: a practical approach. 3 rd. ed. [S.1.]: Practical Approach, (2000).

[101]THERY, M. Micropatterning as a tool to decipher cell morphogenesis and functions. Journal of Cell Science, v. 123, n. 24, p. 4201 4213, (2010).

[102]BOAL, D. H. Mechanics of the cell. 2nd. ed. [S.1.]: (Cambridge, UK), (2012).

[103]EBERLI, D. Tissue Engineering for Tissue and Organ Regeneration. [S.1.]: InTech, (2011).

[104]BUTLER, M. Animal Cell Culture and Technology. 2nd. ed. [S.1.]: Garland Science/BIOS Scientific Publishers, (2004).

[105]GRIVICICH, I.; REGNER, A.; ROCHA, A. B. Morte celular por apoptose. Revista Brasileira de Cancerologia, v. 53, n. 3, p. 335 343, (2007). 
[106]OUYANG, L.; SHI, Z.; ZHAO, S.; FT, W.; TT, Z.; LIU, B.; BAO, J. K. Programmed cell death pathways in cancer: a review of apoptosis, autophagy and programmed necrosis. Cell Prolif. 2012., v. 45(6), n. 6, p. 487 98, (2012).

[107]SALVADORI, M. C.; MARTINS, D. R.; CATTANI, M. Dlc coating roughness as a function of film thickness. Surface Coating and Technology, v. 200, p. 5119 5122, (2006).

[108]BROWN, I. G. The Physics and Technology of Ion Sources. 2nd. ed. [S.1.]: Wiley-VCH, (2004).

[109]PHARR, G. M.; CALLAHAN, D. Hardness, elastic modulus, and structure of very hard carbon films produced by cathodicâi $i \frac{1}{2}$ arc deposition with substrate pulse biasing. Applied Physics Letters, v. 68, n. 6, p. 779 781, (1996).

[110]SALVADORI, M. C.; TEIXEIRA, F. S.; ARAÚJO, W.; SGUBIN, L. G.; BROWN, I. G. Interface tailoring for adhesion enhancement of diamond-like carbon thin films. Diamond and Related Materials, v. 25, p. 8 12, (2012).

[111]SALVADORI, M. C.; TEIXEIRA, F. S.; ARAÚJO, W.; SGUBIN, L. G.; SPIRIN, R.; CATTANI, M.; BROWN, I. G. Gold nanoparticle formation in diamond-like carbon using two different methods: Gold ion implantation and co-deposition of gold and carbon. Journal of Applied Physics, v. 112, p. 074312, (2012).

[112]SALVADORI, M. C.; TEIXEIRA, F. S.; ARAÚJO, W. W. R.; SGUBIN, L. G.; SOCHUGOV, N. S.; SPIRIN, R.; BROWN, I. G. A high voltage pulse power supply for metal plasma immersion ion implantation and deposition. Review of Scientific Instruments, v. 81, p. 124703, (2010).

[113]VADGAMA, P. Surfaces and interfaces for biomaterials. [S.1.]: (CRC Press LLC, USA), (2000).

[114]VIZIR, A.; OKS, E. M.; SALVADORI, M. C.; TEIXEIRA, F. S.; BROWN, I. G. Small plasma source for materials application. Review of Scientific Instruments, v. 78, 086103 (2007).

[115]KULKARNI, A. V.; MATE, N.; KANETKAR, S. M.; OGALE, S. B. Surf. and Coat. Technol., v. 54/55, p. 508, (1992).

[116]DAVENAS, J.; BOIYEUX, G. Adv. Matter., v. 2, p. 251, (1990).

[117]MAZZOLDI, P. Journal of Non-Cryst. Solids, v. 120, p. 223, (1990).

[118]SALVADORI, M. C.; TEIXEIRA, F. S.; SGUBIN, L.; ARAÚJO, W.; SPIRIN, R.; OKS, E. M.; YU, K. M.; BROWN, I. G. Low cost ion implantation technique. Applied Physics Letters, v. 101, p. 22410412241044, (2012).

[119]SALVADORI, M. C.; TEIXEIRA, F. S.; SGUBIN, L.; ARAÚJO, W.; SPIRIN, R.; OKS, E. M.; BROWN, I. G. Performance of an inverted ion source. Review of Scientific Instruments, v. 84, p. 02350610235065 , (2013).

[120]ANDERS, A. Handbook of Plasma Immersion Ion Implantation \& Deposition. [S.1.]: John Wiley \& Sons, (2000).

[121]MöLLER, W.; ECKSTEIN, W. Nucl. Instrum. Meth. Phys. Res. B, v. 2, p. 814, (1984). 
[122]MöLLER, W.; ECKSTEIN, W.; BIERSACK, J. P. Comput Phys. Commun., v. 51, p. 355, (1988).

[123]ZIEGLER, J. F.; BIERSACK, J. P.; LITTMARK, U. The Stopping and Range of Ions in Solids (Pergamon, New York, 1985 (new edition in 1996)). The computer code is downloadable from the SRIM website http://www.srim.org/.

[124]CHAUDHRI, B. P.; CEYSSENS, F.; MOOR, P. D.; HOOF, C. V.; PUERS, R. A high aspect ratio $\{\mathrm{su}\}-8$ fabrication technique for hollow microneedles for transdermal drug delivery and blood extraction. Journal of Micromechanics and Microengineering, v. 20, n. 6, p. 064006, (2010).

[125]MADOU, M. J. Fundamentals of Microfabrication-The Science of Miniaturization. 2. ed. [S.1.]: CRC Press, (2002).

[126]TEIXEIRA, F. S. Anisotropia de Resistividade Elétrica em Filmes Finos Nanoestruturado. Dissertação (Mestrado) - Curso de Pós-graduação em Engenharia Elétrica, Escola Politécnica da Universidade de São Paulo, junho 2007. 92p.

[127]ARAÚJO, W. W. R. Modificação de superfície de diamante utilizando plasma e caracterização por kelvin force microscopy. Dissertação (Mestrado) — Instituto de Física, Nov (2010).

[128]RIBEIRO, D. A.; MARQUES, M. E. A.; SALVADORI, D. M. F. Genotoxicity and cytotoxicity of glass ionomer cements on chinese hamster ovary (cho) cells. J Mater Sci: Mater Med, v. 17, n. 6, p. 495 500, (2006).

[129]VERMA, H. R. Atomic and Nuclear Analytical Methods. [S.1.]: (C)Springer-Verlag Berlin Heidelberg, (2007).

[130]CULLITY, B. D. Elements of X-ray crystallography. [S.1.]: Addison-Wesley Publishing Company, (1956).

[131]CHU, W. K.; MAYER, J. W.; NICOLET, M.-A. Backscattering Spectrometry. [S.1.]: Academic Press INC, (1978).

[132]SILVA, L. F. M. da; OCHSNER, A.; ADAMS, R. D. (Ed.). Handbook of Adhesion Technology. [S.1.]: Springer-Verlag Berlin Heidelberg, (2011).

[133]RAFAEL, T. Line energy and the relation between advancing, receding, and young contact angles. Langmuir, v. 20, n. 18, p. 7659 7664, (2004).

[134]OZCAN, C.; HASIRCI, N. Evaluation of surface free energy for pmma films. Journal of Applied Polymer Science, v. 108, n. 1, p. 438 446, (2008).

[135]KWOK, S. C.; WANG, J.; CHU, P. K. Surface energy, wettability, and blood compatibility phosphorus doped diamond-like carbon films. Diamond and Related Materials, v. 14, n. 1, p. 78 85, (2005).

[136]OSTROVSKAYA, L.; PEREVERTAILO, V.; RALCHENKO, V.; DEMENTJEV, A.; LOGINOVA, O. Wettability and surface energy of oxidized and hydrogen plasma-treated diamond films. Diamond and Related Materials, v. 11, n. 3-6, p. 845 850, (2002). 
[137]ZHAO, Q.; LIU, Y.; ABEL, E. Effect of temperature on the surface free energy of amorphous carbon films. Journal of Colloid and Interface Science, v. 280, n. 1, p. 174 183, (2004).

[138]CELII, F. G.; BUTLER, J. E. Diamond chemical vapor deposition. Annual Review of Physical Chemistry, v. 42, n. 1, p. 643 684, (1991).

[139]ZEBDA, A.; SABBAH, H.; ABABOU-GIRARD, S.; SOLAL, F.; GODET, C. Surface energy and hybridization studies of amorphous carbon surfaces. Applied Surface Science, v. 254, n. 16, p. 4980 4991, (2008).

[140]ZENKIEWICZ, M. Methods for the calculation of surface free energy of solids. Journal of Achievements in Materials and Manufacturing Engineering, v. 24, n. 1, p. 137 145, September (2007).

[141]ERBIL, H. Y. Surface Chemistry Of Solid and Liquid Interfaces. [S.1.]: Blackwell Publishing Ltd, (2006).

[142]CHIBOWSKI, E.; TERPILOWSKI, K. Surface free energy of sulfurRevisited: I. Yellow and orange samples solidified against glass surface. Journal of Colloid and Interface Science, v. 319, n. 2, p. 505 513, (2008).

[143]CARRÉ, A. Polar interactions at liquid/polymer interfaces. J. Adhesion Sci. Technol., v. 21, n. 10, p. 961 981, (2007).

[144]BERGER, R.; BUTT, H.-J.; RETSCHKE, M. B.; WEBER, S. A. L. Macromolecular Rapid Communications, v. 30, n. 14, p. 1167 1178, (2009).

[145]BUTT, H.-J.; CAPPELLA, B.; KAPPL, M. Force measurements with the atomic force microscope: Technique, interpretation and applications. Surface Science Reports, v. 59, n. 1-6, p. 1 152, (2005).

[146]FREWIN, C. L. Atomic Force Microscopy Investigations into Biology: From Cell to Protein. [S.1.]: Intech, Croatia,, (2012).

[147]SALVADORI, M. C. Notas de aula do curso de pós-graduação do Departamento de Física Aplicada Fap 5733. (2008).

[148]SHAH, A. K.; SINHA, R. K.; HICKOK, N. J.; TUAN, R. S. High-resolution morphometric analysis of human osteoblastic cell adhesion on clinically relevant orthopedic alloys. Bone, v. 24, n. 5, p. 499 506, (1999).

[149]FUKASAWAWA, T.; SATO, T. Phys. Chem. Chem. Phys., v. 13, p. 3187 3196, (2011).

[150]ROYALL, C. P.; LOUIS, A. A.; TANAKA, H. The Journal Of Chemical Physics, v. 127, p. 044507, (2007).

[151]PEDERSEN, J. S. Advances in Colloid and Interface Science, v. 70, p. 171 210, (1997).

[152]PERUANI, F.; SCHIMANSKY-GEIER, L.; BAR, M. Eur. Phys. J. Special Topics, v. 191, p. 173 185, (2010).

[153]ZHANG, H.; ANGUS, S.; TRAN, M.; XIE, C.; IGOSHIN, O. A.; WELCH, R. D. Journal Of Bacteriology, v. 193, n. 19, p. 5164 5170, (2011). 
[154]LOERKE, D.; DUC, Q.; BLONK, I.; KERSTENS, A.; SPANJAARD, E.; MACHACEK, M.; DANUSER, G.; ROOIJ, J. Science Signaling, v. 5, n. 231, p. 1 13, rs5 (2012).

[155]COSTA, L. F.; CESAR JR., R. M. Shape Analysis and classification: Theory and Practice. 3 rd. ed. [S.1.]: CRC Press, (2000).

[156]HEILBRONNER, R. P. Tectonophysics, v. 212, p. 351 370, (1992).

[157]KIM, B.; CARIGNANO, M. A.; TRIPP, S. L.; WEI, A. Langmuir, v. 20, p. 93609365 , (2004).

[158]BERRYMAN, J. G.; BLAIR, S. C. J. App. Phys., v. 60, p. 1930, (1986).

[159]HUNT, B.; LIPSMAN, R.; ROSENBERG, J.; COOMBES, K.; OSBORN, J.; STUCK, G. A Guide to MATLAB for Beginners and Experienced Users. [S.1.]: Cambridge University Press, (2001).

[160]SEMMLOW, J. L. Biosinal and Biomedical Image Processing: Matlab-Base Applications. [S.1.]: (Marcel Dekker, NY, U.S.A), (2004).

[161]HAHN, B. D.; VALENTINE, D. T. Essential MATLAB for Engineers and Scientists. 3 rd. ed. [S.1.]: Elsevier, (2007).

[162]PFLEIDERER, S.; BALL, D. G. A.; BAILEY, R. C. Computers \& Geosciences, v. 19, n. 6, p. $825829,(1993)$.

[163]EIDET et al. Diagnostic Pathology 2014, v. 9, n. 92, p. 1 9, (2014).

[164]RASBAND, W. S. ImageJ. imagej.nih.gov/ij/, (19972012).

[165]ABRàMOFF, M. D.; MAGALHãES, P. J.; RAM, S. J. Image processing with imagej. Biophotonics International, v. 11, n. 7, p. 36 42, (2004).

[166]SCHNEIDER, C. A.; RASBAND, W. S.; ELICEIRI, K. W. Nih image to imagej: 25 years of image analysis. Nature Methods, v. 9, n. 7, p. 671 675, (2012).

[167]SCHINDELIN, J.; ARGANDA-CARRERAS, I.; FRISE, E.; KAYNIG, V.; LONGAIR, M.; PIETZSCH, T.; PREIBISCH, S.; RUEDEN, C.; SAALFELD, S.; SCHMID, B.; TINEVEZ, J.-Y.; WHITE, D. J.; HARTENSTEIN, V.; ELICEIRI, K.; TOMANCAK, P.; CARDONA, A. Fiji: an open-source platform for biological-image analysis. Nature Methods, v. 9, n. 7, p. 676 682, (2012).

[168]WORMINGTON, M.; PANACCIONE, C.; MATNEY, K. M.; BOWEN, D. K. Characterization of structures from x-ray scattering data using genetic algorithms. Phil. Trans. R. Soc. Lond. A., v. 357, p. 1761, (1999).

[169]GOMPPER, G.; SCHICK, M. Lattice model of microemulsions. Physical Review B, American Physical Society ( $\{$ APS $\}$ ), v. 41, n. 13, p. 9148 9162, may (1990). Disponível em: $<$ http://dx.doi.org/10.1103/PhysRevB.41.9148>.

[170]MITCHELL, S. A.; EMMISON, N.; SHARD, A. G. Spatial control of cell attachment using plasma micropatterned polymers. Surf. Interface Anal., v. 33, n. 9, p. 742 747, (2002).

[171]CHUNG, S. H.; SON, S. J.; MIN, J. Nanotechnology, v. 21, p. 125104, (2010). 
[172]STEPANOV, A.; HOLE, D.; TOWNSEND, P. Formation of silver nanoparticles in soda-lime silicate glass by ion implantation near room temperature. Journal of Non-Crystalline Solids, v. 260, n. 1-2, p. 65 74, (1999).

[173]SL, V.; BB, M.; SA, S.; EN, C.; DA, H. et al. Correlation functions quantify superresolution images and estimate apparent clustering due to over-counting. PLOS ONE, v. 7, n. 2, p. e31457, (2012). 